Universidade de São Paulo

Faculdade de Filosofia, Letras e Ciências Humanas

Departamento de História

\title{
BANDEIRISMO PAULISTA: O AVANÇO NA COLONIZAÇÃO E EXPLORAÇÃO DO INTERIOR DO BRASIL (TAUBATÉ, 1645 A 1720)
}

Leandro Santos de Lima

São Paulo

2011 
Universidade de São Paulo

Faculdade de Filosofia, Letras e Ciências Humanas

Departamento de História

\section{BANDEIRISMO PAULISTA: O AVANÇO NA COLONIZAÇÃO E EXPLORAÇÃO DO INTERIOR DO BRASIL (TAUBATÉ, 1645 A 1720)}

Dissertação apresentada ao Programa de pósgraduação em História Social do Departamento de História da Faculdade de Filosofia, Letras e Ciências Humanas da Universidade de São Paulo, para a obtenção do título de mestre em História

Leandro Santos de Lima leandrodelima@usp.br

Orientadora:

Prof $^{\mathrm{a}}$. Dr ${ }^{\mathrm{a}}$. Laura de Mello e Souza

São Paulo

2011 
Aos que avançaram em direção ao

desconhecido e temido mundo além do horizonte. 


\section{Resumo:}

Até poucas décadas atrás reinava a idéia de que o bandeirismo paulista tinha sido o resultado natural de uma "raça de gigantes" que foi obrigada, devido ao suposto abandono da metrópole, a adentrar o sertão para buscar o remédio para sua pobreza. Essa definição colocava tal fenômeno histórico num patamar de influências exclusivamente locais, considerando-o atípico e isolado de qualquer relação com a empresa colonial portuguesa. Porém, a historiografia atual, ao revisitar esse tema, vem propondo novos caminhos analíticos diferentes daqueles que até então vigoravam. Seguindo a atual tendência, a presente pesquisa teve por objetivo analisar pontualmente o bandeirismo taubateano, entre os anos de 1645 e 1720, como um fenômeno histórico, fruto de um processo econômico, social e político, tanto de caráter local, como também, colonial. Verificou-se que a segunda metade do século XVII assistiu a uma reorientação nas incursões sertanistas, tanto de caça ao índio como de pesquisa mineral. Essas atividades, se por um lado eram financiadas pelo capital privado, que podia, ou não, ser do próprio grupo social bandeirante, por outro lado recebiam o incentivo oficial vindo da metrópole por meio da correspondência entre os agentes oficiais da administração portuguesa. O bandeirante, visando a dominação do poder local, desejava não só enriquecer, mas também enobrecer; já a coroa desejava a injeção de novas riquezas e, para isso, precisava do colono para aprofundar a exploração de suas terras na América, daí incentivar tais incursões com a promessa de honras, mercês e títulos. No jogo de interesses, a relação era simbiótica, ou seja, era uma "empresa em conjunto". Enfim, tanto o grupo bandeirante local quanto a monarquia lusitana desejavam a mesma coisa: a manutenção do poder.

Palavras-chaves: Bandeirismo, Taubaté, colônia, sociedade. 


\begin{abstract}
:
Until a few decades ago the idea that prevailed was that the bandeirismo paulista was the natural outcome of a "race of giants" that was forced, due to the supposed abandonment of the metropolis, to penetrate the wilderness to seek remedy for their poverty. This definition would put such a historical phenomenon in a purely local level influences, considering atypical and isolated from any relationship with the Portuguese colonial enterprise. However, the current historiography, to revisit the issue, has been proposing new analytical paths other than those previously prevailing. Following current trends, this research aimed to analyze the "bandeirismo taubateano" punctually, between the years 1645 and 1720, as a historical phenomenon, the result of an economic process, social and political character of both local as well as colonial. It was found that the second half of the seventeenth century witnessed a shift in raids frontiersmen, both of Indian hunting and mineral exploration. Such activities, if one part were financed by private capital, which could, or may not be the group's own social bandeirante, on the other side received the official encouragement coming from the metropolis through the correspondence between the official agents of the Portuguese administration. The bandeirante, seeking the domination of local government, wanted not only to be rich but also ennobling, even the crown wanted to inject new wealth and for this, the settler needed to further exploitation of their lands in America hence encouraging such incursions with the promise of honors, titles and favors. In the game of interests, the relationship was symbiotic, it was "a company together." Finally, both the local bandeirante group as the Lusitanian monarchy wanted the same thing: keeping the power.
\end{abstract}

Key words: Bandeirismo, Taubaté, colony, society. 


\section{AGRADECIMENTOS}

Após um longo tempo de pesquisa, após muitas noites mal dormidas devido as dificuldades que teimavam em aparecer no percurso dos estudos, após páginas e mais páginas escritas e reescritas, chegar até aqui, isto é, aos finalmentes, é um alívio. Ledo engano! Expressar os meus agradecimentos não será tarefa fácil mesmo porque nada do que for dito a seguir estará a altura do que realmente sinto, porém, é meu dever correr esse risco. Então, aqui vai.

Em primeiro lugar, sou imensamente grato a Prof ${ }^{\mathrm{a}}$. Dr ${ }^{\mathrm{a}}$. Laura de Mello e Souza não apenas pela orientação, mas principalmente pela oportunidade a mim dada. Depois de muito percorrer os corredores da Universidade de São Paulo, foi ela quem me abriu as portas e acolheu as minhas ideias, assim, tudo isso só foi possível graças a sua generosidade e profissionalismo.

Agradeço também muitíssimo aos meus pais, Lier e Glaucia, que nunca questionaram sobre minhas escolhas, ao contrário, percorri todo este caminho até agora somente porque sempre encontrei neles todo o apoio necessário.

A Deisy Gomes, companheira de todas as horas. Com certeza, depois de mim, ela foi a pessoa que mais se envolveu nessa empreitada. Peço mil desculpas pelos dias de mauhumor, pelas preocupações que tomavam o nosso cotidiano, pelo confinamento que os estudos exigiram, enfim, por tudo aquilo que de alguma causou transtornos. Saiba que tudo que fiz, que faço e que irei fazer é sempre pensando em nós.

A Prof ${ }^{\mathrm{a}}$. Lia Carolina Prado Alves Mariotto, paleógrafa responsável pelo Arquivo Histórico Municipal de Taubaté. Além de me ensinar a arte de decifrar documentos, fez com que eu me apaixonasse pela História e sentisse prazer em sentar de frente ao passado materializado em velhos papéis que cheiram, muitas vezes, ao esquecimento. Nossas conversas foram fundamentais para a elucidação de diversas questões.

Ao Prof. Dr. Isnard de Albuquerque Câmara Neto, a quem muito estimo e respeito. Tenho o privilégio de contar não apenas com o seu apoio intelectual, mas também, e principalmente, com sua amizade.

Ao Prof. Fred Humbert Reis Savino que sempre se dispôs a compartilhar comigo suas ideias e reflexões acerca dos mais variados temas da História, contribuindo, dessa maneira, para meu desenvolvimento como pesquisador.

Aos amigos Francisco Maia, David Rodrigues e Diogo Gil que fizeram, indiscutivelmente, parte de toda a minha trajetória, ora nos momentos mais difíceis ora naqueles de descontração.

Aos professores Carlos de Almeida Prado Bacellar e Maria Aparecida Borrego, membros que compuseram a banca de exame de qualificação pelas críticas e apontamentos.

E por último, mas não menos importante, ao Fundo de Amparo à Pesquisa do Estado de São Paulo (FAPESP) que me concedeu uma bolsa de pesquisa sem a qual seria quase que impossível o desenvolvimento de meus estudos. 


\section{SUMÁRIO}

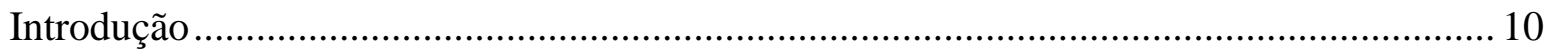

Capítulo 1: Bandeirismo e Colonização na Capitania Paulista............................................. 15

1.1 Historiografia e Definições do Objeto.......................................................................... 15

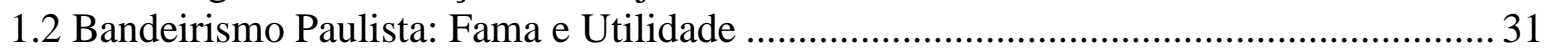

1.3 Restauração Portuguesa e Crise Econômica.................................................................... 35

1.4 A Política de Incentivos: Prestação de Serviços e Recompensas ....................................... 42

Capítulo 2: A Vila de São Francisco das Chagas de Taubaté ...............................................54

2.1 Vale do Rio Paraíba: Exploração e Povoamento............................................................ 54

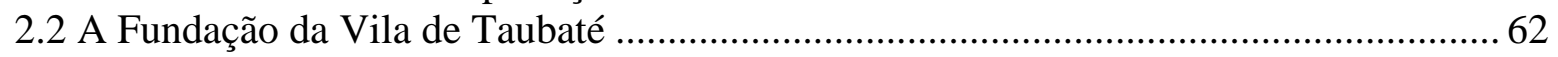

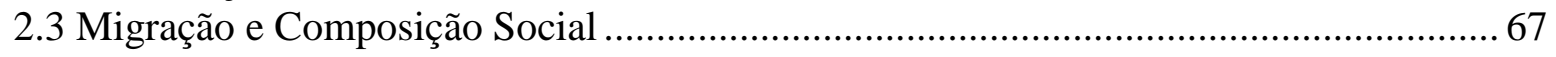

2.4 Economia Local e Distribuição da Riqueza ………………………………………........ 86

2.5 Desigualdade Social e Interesses Econômicos Variados............................................... 102

2.6 Cargos Públicos: a Câmara Municipal e as Ordenanças Militares .................................. 115

Capítulo 3: O Grupo Sertanista Taubateano.............................................................................126

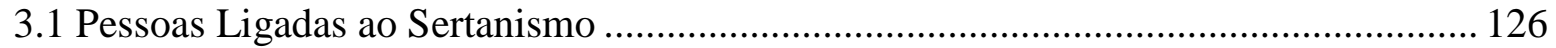

3.2 Universo Econômico dos Sertanistas ...................................................................... 133

3.2.1 Formas de Organização e de Participação nas Entradas Sertanistas .......................... 141

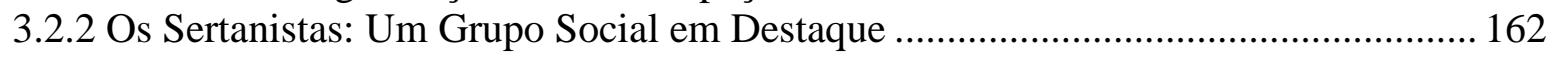

3.3 Poder Político e Militar dos Sertanistas..................................................................... 187

Capítulo 4: Carlos Pedroso da Silveira - Sertanismo e Vida Pública ............................. 199

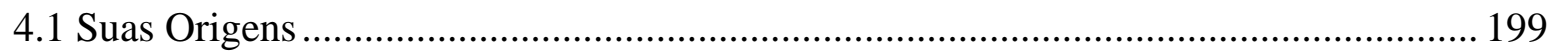

4.2 Sertanista, Militar e Político ………………….............................................................. 204

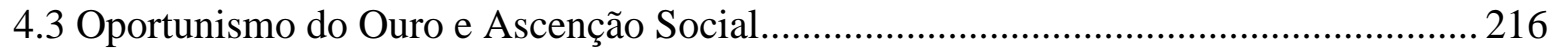

4.4 Limites, Frustração e Morte................................................................................... 223

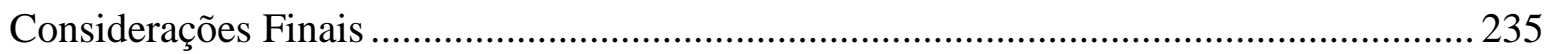

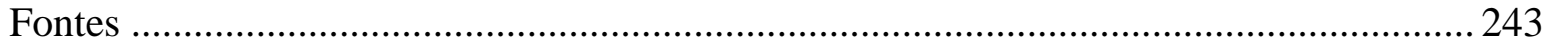

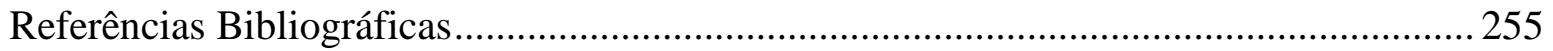




\section{ÍNDICE DE GRÁFICOS}

Gráfico 1: Percentual de população livre e escrava de Taubaté ......................................... 79

Gráfico 2: Porcentagem dos diferentes tipos de plantações cultivadas em Taubaté ............94

Gráfico 3: Porcental de pessoas que ocuparam o cargos de juiz em Taubaté .................... 120

Gráfico 4: Indivíduos que tiveram patentes militares em Taubaté.................................. 124

Gráfico 5: Porcentagem de indivíduos envolvidos nas entradas sertanistas ..................... 127

Gráfico 6: Ditribuição dos inventários dos sertanistas de Taubaté em comparação à documentação em geral segundo as diferentes faixas de riqueza bruta (1650)................. 172 Gráfico 7: Ditribuição dos inventários dos sertanistas de Taubaté em comparação à documentação em geral segundo as diferentes faixas de riqueza bruta (1660) ................. 173 Gráfico 8: Ditribuição dos inventários dos sertanistas de Taubaté em comparação à documentação em geral segundo as diferentes faixas de riqueza bruta (1670) .................. 174 Gráfico 9: Ditribuição dos inventários dos sertanistas de Taubaté em comparação à documentação em geral segundo as diferentes faixas de riqueza bruta (1680) ................ 175 Gráfico 10: Ditribuição dos inventários dos sertanistas de Taubaté em comparação à documentação em geral segundo as diferentes faixas de riqueza bruta (1690) ................ 175 Gráfico 11: Ditribuição dos inventários dos sertanistas de Taubaté em comparação à documentação em geral segundo as diferentes faixas de riqueza bruta (1700) ................ 176 Gráfico 12: Ditribuição dos inventários dos sertanistas de Taubaté em comparação à documentação em geral segundo as diferentes faixas de riqueza bruta (1710) ................ 177 Gráfico 13: Comparação da porcentagem da riqueza geral e dos sertanistas de Taubaté ..182 Gráfico 14: Porcentagem de juízes que foram sertanistas em Taubaté ............................. 188 Gráfico 15: Porcentagem entre juízes sertanistas e não sertanistas ................................ 191

Gráfico 16: Porcentagem de sertanistas que foram juízes em Taubaté ............................. 193

Gráfico 17: Porcentagem de sertanistas que tinham patentes militares ........................... 195

Gráfico 18: Porcentagem da distribuição de patentes militares entre sertanistas e não

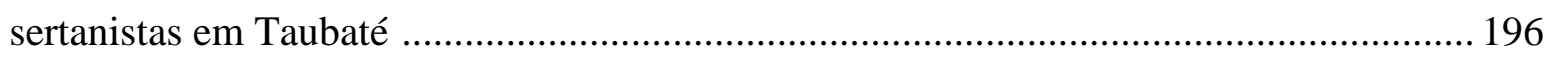

Gráfico 19: Porcentagem de sertanistas que tinham patentes militares ........................... 197 


\section{ÍNDICE DE TABELAS}

Tabela 1: Composição da riqueza em valores reais por setor econômico ................................ 88

Tabela 2: Composição da riqueza em porcentagem por setor econômico ………………...... 89

Tabela 3: Origem das dívidas encontradas em Taubaté ………………………………..... 100

Tabela 4: Distribuição dos inventários dos habitantes de Taubaté segundo as diferentes faixas de riqueza bruta (1650) ................................................................................... 103

Tabela 5: Distribuição dos inventários dos habitantes de Taubaté segundo as diferentes

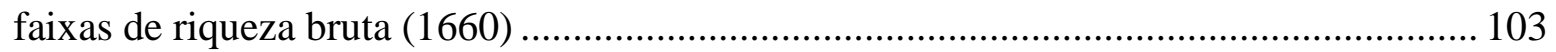

Tabela 6: Distribuição dos inventários dos habitantes de Taubaté segundo as diferentes faixas de riqueza bruta (1670) .................................................................................... 104

Tabela 7: Distribuição dos inventários dos habitantes de Taubaté segundo as diferentes

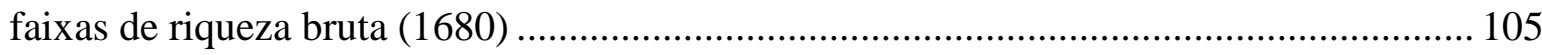

Tabela 8: Distribuição dos inventários dos habitantes de Taubaté segundo as diferentes

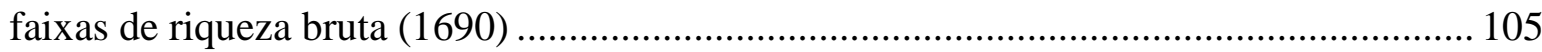

Tabela 9: Distribuição dos inventários dos habitantes de Taubaté segundo as diferentes

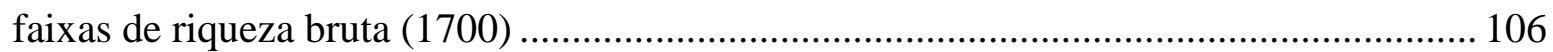

Tabela 10: Distribuição dos inventários dos habitantes de Taubaté segundo as diferentes

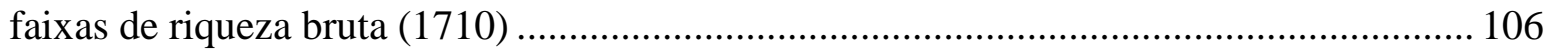

Tabela 11: Distribuição da riqueza bruta da vila de Taubaté imobilizada em cada tipo de

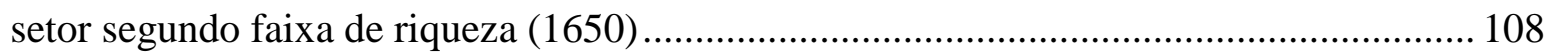

Tabela 12: Distribuição da riqueza bruta da vila de Taubaté imobilizada em cada tipo de

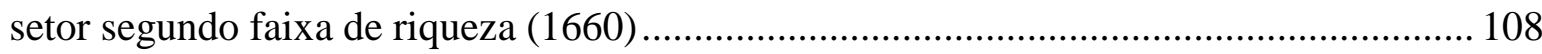

Tabela 13: Distribuição da riqueza bruta da vila de Taubaté imobilizada em cada tipo de setor segundo faixa de riqueza (1670) ........................................................................... 109 Tabela 14: Distribuição da riqueza bruta da vila de Taubaté imobilizada em cada tipo de setor segundo faixa de riqueza (1680) ......................................................................... 112 Tabela 15: Distribuição da riqueza bruta da vila de Taubaté imobilizada em cada tipo de setor segundo faixa de riqueza (1690) ...................................................................... 112 Tabela 16: Distribuição da riqueza bruta da vila de Taubaté imobilizada em cada tipo de

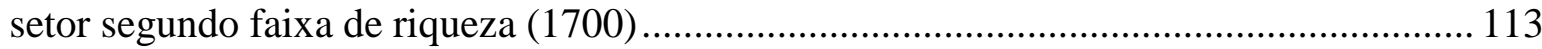

Tabela 17: Distribuição da riqueza bruta da vila de Taubaté imobilizada em cada tipo de setor segundo faixa de riqueza (1710) ........................................................................... 113

Tabela 18: Número real de inventários de indivíduos envolvidos nas entradas sertanistas,

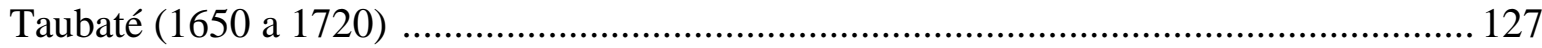

Tabela 19: Composição da riqueza dos sertanistas por setor econômico (real) .................. 134

Tabela 20: Composição da riqueza dos sertanistas por setor econômico (\%) ..................... 134

Tabela 21: Riqueza dos sertanistas em comparação a riqueza geral (1650-1660) ............. 163

Tabela 22: Riqueza dos sertanistas em comparação a riqueza geral (1670-1680) ............. 164

Tabela 23: Riqueza dos sertanistas em comparação a riqueza geral (1690-1700) ............. 166

Tabela 24: Riqueza dos sertanistas em comparação a riqueza geral (1710) ...................... 168 


\section{ABREVIATURAS}

Cx - Caixa

Doc - Documento

f. - fólio

A. H. M. T. - Arquivo Histórico Municipal de Taubaté

USP - Universidade de São Paulo

FFLCH - Faculdade de Filosofia, Letras e Ciências Humanas

R.I.H.G.S.P. - Revista do Instituto Histórico Geográfico de São Paulo

R.I.H.G.B. - Revista do Instituto Histórico Geográfico Brasileiro 


\title{
INTRODUÇÃO
}

\author{
Taubaté das bandeiras - que ousaram \\ desbravar ínvias selvas, com glória. \\ Taubaté, cujos filhos não param, \\ sempre em marcha nas asas da História. \\ Taubaté das Monções, na erradia \\ epopéia por rios e lapas, \\ qual titã a fazer Geografia, \\ implantando fronteiras nos mapas! ${ }^{1}$
}

Essa é a primeira estrofe do Hino oficial da cidade de Taubaté. Feito na década de 1970, sua letra exalta as ações dos taubateanos ao longo da história, dentre elas, o bandeirismo que foi escolhido como a de maior grandeza.

Reconhecidamente, a vila de Taubaté "tornar-se-ia núcleo bandeirante da maior importância." "2 Desde a sua fundação, iniciada ainda na década de 1630 e consolidada na seguinte, esteve intimamente ligada às atividades sertanistas, tanto de caça ao índio como de prospecção. De um lado, a aquisição de massa indígena foi utilizada como mão-de-obra escrava e serviu para a montagem e manutenção do sistema produtivo da vila, coisa de vital importância para a sobrevivência e crescimento do local. Porém, foi nas buscas por pedras e metais preciosos que a fama se estabeleceu, ou seja, "sua atuação veio a ser sobremaneira notável com a abertura do ciclo do ouro. Seriam os taubateanos os pioneiros de tal fase."3 Logo, "foi ademais grande a participação dos moradores da vila de Taubaté na própria descoberta do ouro."

Na verdade, não obstante tal reconhecimento, muito pouco se conhece sobre os primórdios de Taubaté. A começar pelo seu próprio envolvimento no bandeirismo paulista, tido como crucial para o avanço na exploração mineral do Brasil, mas que é lembrado apenas por meio dos nomes de alguns famosos sertanistas que viveram bem próximos aos acontecimentos que tiveram parte na descoberta oficial de ouro nas Gerais ocorrida em fins do século XVII.

\footnotetext{
${ }^{1}$ FLORENÇANO, Paulo Camilher. O Brasão e a Bandeira de Taubaté. 2a . ed. Taubaté: Resolução Gráfica. p. 49.

2 TAUNAY, Affonso de E. História das Bandeiras Paulistas. São Paulo: Edições Melhoramentos, Tomo I, $2^{a}$ Edição, 1961. p. 207.

${ }^{3}$ Idem, Ibidem. p. 207.

${ }^{4}$ ALVES, Maurício Martins. Caminhos da Pobreza: a manutenção da diferença em Taubaté (16801729). Taubaté: Prefeitura Municipal, 1999. p. 14.
} 
É preciso avançar no conhecimento do bandeirismo taubateano para além do que se sabe e rever algumas considerações de pouca sustentação. Primeiramente, o achamento de ouro nas Gerais foi o resultado de todo um processo histórico que teve início desde os primeiros tempos da colonização portuguesa na América e, por isso mesmo, não deve ser visto como fruto da ação de uma ou outra pessoa em particular. Taubaté não foi a única responsável direta por tal feito, ela fez parte deste processo juntamente com outras vilas que de igual maneira ofereceram homens e materiais para essa empreitada. Sem mencionar o envolvimento de representantes do governo português, muitas vezes tão intensa que caracterizava uma espécie de política voltada para o bandeirismo paulista, principalmente no período pós-1640, quando ocorre a Restauração Bragantina.

Muitos são os documentos que asseguram a participação de taubateanos nas incursões que percorreram a região mineira, mesmo antes da descoberta oficial. Consta no inventário de Miguel Fernandes Edra, por exemplo, datado de 29 de agosto de 1667, que ele havia recebido de seu compadre Pedro Gil seis libras de pólvora e chumbo para ser usado "em serviço do arraial" e "não gastando eu the entregaria a qual se molhou alagandome no Rio das Velhas", isto é, Miguel estava a caminho de um assentamento que se localizava para além deste rio, onde hoje é Minas Gerais. ${ }^{5}$ Outro que também esteve em território mineiro foi Francisco Pedroso que, em 1687, se encontrava no sertão do Caeté. ${ }^{6}$ Enfim, são trechos e mais trechos de documentação coeva que mostram a circulação de habitantes da vila de Taubaté nas bandeiras que adentravam o sertão, a sua maioria em direção às futuras Minas Gerais.

Como citado anteriormente, o governo colonial também esteve junto aos acontecimentos que espreitaram a procura de pedras e metais preciosos, ora sob uma aproximação mais intensa, ora se omitindo de certos encargos, mas quase sempre a par dos fatos. Os agentes oficiais da colonização portuguesa no Brasil, aqueles que eram os responsáveis pela manutenção da ordem - isso inclui o avanço no processo de exploração acompanharam de perto as atividades sertanistas, principalmente as praticadas pelos paulistas, sejam orientados por objetivos pessoais, sejam a mando da Coroa. Em documento datado de 9 de julho de 1685, José Cubas Raposo, morador em Taubaté, esteve presente

\footnotetext{
${ }^{5}$ Inventário de Miguel Fernandes Edra (1667). Cx: 1649-1667. A.H.M.T.

${ }^{6}$ Inventário de Francisco Pedroso (1687). Cx: 1678-1689. A.H.M.T.
} 
numa bandeira que percorreu o sertão dos Cataguás. ${ }^{7}$ Durante tal viagem, José faleceu e o responsável pela bandeira, o Capitão-mor Estevão Raposo Barbosa, um alto "funcionário" da administração colonial, mandou que o escrivão do arraial que naquele lugar havia fizesse inventário de seus bens. Esta situação revela indícios de que dentro de todo este processo que culminou no achamento de ouro os interesses se entrelaçavam, sendo que de um lado havia o colono e de outro os representantes da Coroa portuguesa. Conscientemente ou não, todos contribuíram para o avanço na exploração da colônia, o que era do desejo da metrópole, sempre beneficiada com isso.

Buscando relacionar pontos de vista de diferentes panoramas, ora mais amplos, ora mais pontuais, os objetivos desta dissertação podem ser enumerados da seguinte forma: 1) situar o bandeirismo paulista dentro do processo de colonização do Brasil, isto é, entender o bandeirismo como uma prática inerente à própria colonização e, por isso mesmo, útil ao seu avanço; 2) seguindo na linha dos novos estudos históricos sobre São Paulo colonial buscase conhecer melhor a realidade da vila de Taubaté, tanto em termos de economia, de política e de sociedade; 3) por fim, localizar e caracterizar o grupo sertanista taubateano.

O estudo limitou-se à vila de Taubaté devido não apenas a sua importância como centro irradiador de bandeirantes mas também por ter sido a primeira vila da região valeparaibana e, por tal razão, sede da administração política e militar com jurisdição sobre grande área, inclusive agregando algumas outras vilas que foram surgindo gradativamente. Apesar de ser reconhecida pela historiografia como importante vila, principalmente em relação ao sertanismo, Taubaté ainda carece de estudos científicos que busquem revelar seu passado, daí a sua escolha. Já o enquadramento cronológico da pesquisa foi estabelecido da seguinte maneira: tem início em 1645, a data em que Taubaté é elevada à categoria de vila, fazendo com que entrassem em funcionamento as suas atividades camarárias; e o recorte termina em 1720, quando Minas Gerais se desmembra da Capitania de São Paulo, simbolizando o fim da hegemonia paulista na região, além do redirecionamento da atenção dos paulistas, agora voltada para as recém-descobertas minas de Cuiabá e Mato Grosso.

O corpo documental utilizado assentou-se basicamente nos Inventários e Testamentos que se encontram no Arquivo Histórico Municipal de Taubaté. Estes documentos, muitos deles ainda inéditos, trazem a lista de todos os bens (móveis, imóveis,

\footnotetext{
${ }^{7}$ Inventário de José Cubas Raposo (1685). Cx: 1678-1689. A.H.M.T.
} 
dívidas e créditos) dos indivíduos, ou seja, revelam o seu universo material. No que diz respeito às relações sociais, as listas de dívidas e créditos contêm uma grande riqueza de informações, pois fornecem os valores e, em alguns casos, a residência do credor ou devedor. A partir daí, foi possível visualizar com quem os bandeirantes se relacionavam economicamente, a quem prestavam favores e de quem os recebiam, enfim, possibilitou o acesso ao seu universo relacional. Outra importante fonte selecionada para a presente pesquisa é o conjunto de Livros de Registros e Escrituras que está tutelado no mesmo arquivo supracitado. Esses Livros, que também em grande medida foram pouco utilizados no meio acadêmico, forneceram dados a respeito dos negócios estabelecidos entre os membros da própria sociedade taubateana e entre pessoas de diferentes localidades. Essas informações contribuíram para a identificação do modo como eram organizadas as entradas sertanistas e quem eram as pessoas que estavam envolvidas nessas empreitadas.

Após a extração de grande volume de informações que variaram entre quantitativas e qualitativas, e a sua posterior avaliação e reflexão, foi possível construir as argumentações que orientaram o ponto de vista desta dissertação, expostas através de quatro capítulos.

O primeiro deles busca decrifar o fenômeno do bandeirismo à luz de diferentes concepções encontradas na historiografia. Procurou-se questionar as suas causas, as suas intenções e a sua prática, sempre com a preoupação em contextualizá-lo, ou seja, sem isolálo da realidade a sua volta. Nesse sentido, dando especial atenção aos paulistas, discorreuse sobre a forma com que as atividades sertanistas foram praticadas dentro do âmbito dos interesses locais, mas sem deixar de inseri-las no rol dos interesses da Coroa, que buscava cada vez mais efetivar a colonização do Brasil através de sua exploração. Com vistas a alcançar os objetivos propostos para tal capítulo, foi inevitável o amparo dado por conceitos consagrados na historiografia: com relação às reflexões sobre a especialização dos paulistas no sertanismo e a sua possível diferenciação racial - tese esta defendida por muitos autores durante longo tempo - as ideias aqui defendidas se sustentaram na concepção de "unicidade da formação social brasileira" elaborada por Ilana Blaj e na de evolução econômicoprodutiva da capitania paulista que se alimentava do bandeirismo através da constante busca por mão-de-obra indígena, tão bem defendida por John Monteiro. Já quanto à relação 
existente entre Coroa e colonos dentro de um jogo de interesses, considerou-se válida a sua interpretação por meio do conceito de Estado Patrimonial de Max Weber.

O segundo capítulo focou apenas a região do vale do Paraíba e a vila de Taubaté, passando do período de devassamento ao de ocupação e exploração. Houve, de fato, a necessidade de rever grande parte do que foi dito sobre tal assunto, não só porque algumas considerações estavam ultrapassadas, visto que a historiografia sobre São Paulo colonial avançou bastante nos últimos anos, mas também porque surgiu a oportunidade de trabalhar com um corpo documental muito rico em informações e pouco, ou quase nada, explorado pelos estudiosos. Logo, temas como economia, política e sociedade receberam novos olhares.

No capítulo seguinte, após uma melhor definição da realidade colonial de Taubaté, buscou-se localizar e caracterizar os indivíduos ligados às atividades sertanistas. Visando confrontar as velhas imagens consolidadas pela historiografia, procurou-se questionar sobre a parcela populacional envolvida no bandeirismo, sobre as suas características e interesses econômicos, sobre o seu posicionamento social, sobre as formas de organização das entradas sertanistas, além da eventual posse de patentes militares e participação na Câmara municipal.

Por último, no quarto capítulo discorreu-se sobre a vida de Carlos Pedroso da Silveira, sertanista famoso e que esteve intimamente ligado ao movimento bandeirante taubateano. A sua trajetória serviu de exemplo para a compreensão de algumas das características da colonização portuguesa em relação a São Paulo e ao banderismo. 


\section{CAPÍTULO 1 \\ BANDEIRISMO E COLONIZAÇÃO NA CAPITANIA PAULISTA}

Este capítulo foi orientado por dois objetivos que, apesar de distintos, se completam: o primeiro deles é a tipificação do fenômeno "bandeirismo", isto é, suas características, suas causas, suas intenções e sua prática. Por outras palavras, pensou-se em discorrer sobre a ocorrência das incursões mato adentro que, evidentemente, teve início logo nos primeiros anos da colonização do Brasil. Mas ao mesmo tempo a análise percorreu idêntico traçado deixado na História que, de fato, presenciou a progressiva especialização dos paulistas nos assuntos referentes ao sertão. Dessa maneira, foi necessário questionar tal relação - paulista/bandeirismo - relação esta que ocupou em grande medida a atenção dos estudiosos que acabaram por elaborar diferentes teses que visavam explicar esta "natural" associação. Assim, um exame das principais reflexões encontradas na historiografia sobre o assunto foi de fundamental importância para a sua compreensão.

Em segundo lugar, buscou-se inserir o banderismo no processo de colonização portuguesa no Brasil, isto porque foi, e talvez ainda seja, comumente imaginado como um fenômeno atípico, isolado e mesmo contraditório dentro de tal contexto. Na verdade, muitos indícios mostram exatamente o oposto, coisa que foi percebida por alguns autores. Portanto, o foco é a participação do bandeirismo não apenas nos círculos de interesses locais mas também no âmbito mais geral da própria engrenagem da colonização no Brasil, visando mostrar com tudo isso a sua utilidade, tanto da prática como dos seus praticantes.

\subsection{Historiografia e Definições do Objeto}

Na mesma proporção do amplo número de estudos sobre o bandeirismo está a divergência quanto as suas definições. Desde as primeiras obras constituídas ainda no século XVIII até as mais recentes muitas ideias foram elaboradas, ora com certa carga de exaltação e intensionalidades implícitas, ora com grande objetividade científica. Para alguns autores, o sertão exercia "uma provocação, um fascínio constante" naqueles que o viam mais de perto ${ }^{8}$; ao que parece, tal provocação e fascínio também deve ter servido de

${ }^{8}$ ELLIS, Myriam. “As Bandeiras na Expansão Geográfica do Brasil.” In: HOLANDA, Sérgio Buarque de. (org.) História Geral da Civilização Brasileira. Tomo I, Vol. I, Rio de Janeiro: Bertrand,1989. p. 277. 
atrativo para os estudiosos. Não obstante a imensa contribuição dada por cada autor, o tema em alguns pontos ainda se mantém pouco esclarecedor. Nesse sentido, procurar-se-á expor as principais opiniões sobre este objeto visando, quando possível, colaborar com novas informações obtidas em documentação compulsada.

Apesar do termo "expedição" ser usado como uma referência genérica a todas as incursões em direção ao interior do Brasil desde o início da sua colonização e por diferentes partes do território, a sua variação ocorreu de lugar para lugar e de tempos em tempos, o que, de fato, pode ter causado grande confusão entre os pesquisadores. Tamanho, composição, objetivos e responsabilidades são os fatores que determinaram a nomenclatura destas atividades. A dificuldade em se conhecer os pornemores de cada expedição, isto é, a sua organização estrutural, definiu, assim, a própria discordância entre as opiniões correntes na historiografia brasileira.

Para se ter uma ideia da variação nas denominações de tais incursões basta observar os termos encontrados no vocabulário da época. Dizia-se viagem, descobrimento, entrada, jornada, armação, frota ou bandeira. Estas formas, como lembra Glória Porto Kok, referemse unicamente à ação de adentrar o sertão. ${ }^{9}$ No entanto, a historiografia selecionou somente dois destes termos como modelos representativos cada qual com um respectivo significado, quais sejam: bandeira e entrada sertanista.

A bandeira, nome que "provém talvez do costume tupiniquim, referido por Anchieta, de levantar-se uma bandeira em sinal de guerra" 10 , para uns era apenas a partida de homens "empregados em prender e escravizar o gentio indígena", outros o que importa não é o seu objetivo em si, e sim a maneira como foi organizada. Seja para fins de reconhecimento, seja para combater e escravizar indígenas, seja para efetuar buscas a pedras e metais preciosos, interessa verificar o seu revestimento oficial ou não. Para Basílio de Magalhães, por exemplo, as bandeiras eram as incursões "espontâneas"12, já para o Dr. Gentil de Assis Moura "as bandeiras tinham quase sempre um caráter oficial,

\footnotetext{
${ }^{9}$ Cf. KOK, Glória Porto. O Sertão Itinerante: expedições da capitania de São Paulo no século XVIII. São Paulo: Hucitec: Fapesp, 2004.

10 ABREU, Capistrano de. Capítulo de História Colonial, 1500-1800. 7ª ed. Belo Horizonte: Itatiaia; São Paulo: Publifolha, 2000. p. 128.

${ }^{11}$ Idem, Idbem. p. 128.

${ }^{12}$ Cf. MAGALHÃES, Basílio de. Expansão Geográfica do Brasil Colonial. São Paulo: Companhia Editora Nacional, 1935.
} 
porque eram formadas por ordem do governo, sendo registradas na Câmara Municipal o regimento ou instruções com que seguiam, o nome das pessoas que a compunham, fins a que destinava, etc."13

A diferenciação entre bandeiras e entradas sertanistas passa sempre pela sua oficialidade ou não. Alfredo Ellis Jr. entende que as entradas eram empreendimentos oficiais e as bandeiras eram particulares já que recebiam investimentos dos colonos. ${ }^{14}$ Luiza Volpato, por sua vez, também designa as bandeiras como atividades exercidas por influências particulares. ${ }^{15}$ Como Basílio de Magalhães classificou, em parágrafo anterior, as bandeiras sendo obra de essência espontânea, deu, consequentemente, às entradas um sentido oficial. ${ }^{16}$ Há quem prefira dividir em dois o bandeirismo, um de caráter "livre" organizada pelo aventureiro por sua conta e risco - e outro "oficial" - parte de uma política do Estado. ${ }^{17}$

Eliminando um dos termos, assim explica Washington Luís: "esses homens não se diziam bandeirantes, nem às expedições chamavam bandeiras. Faziam entradas ao sertão e eram sertanistas." 18 Bem, na verdade, em um documento com data de 20 de setembro de 1700 está registrado que o filho de um tal Bento Rodrigues retornou "da bandeira donde se descobriu um lacrimal" que se pode extrair ouro, ou seja, houve um equívoco por parte daquele autor. $^{19}$

Enfim, é bastante complicada a questão e, por isso mesmo, não há um consenso entre os estudiosos. Buscando resumir este conflito, mas também contribuindo para aumentar as diferenças de pensamento, Carlos Davidoff diz o seguinte:

No tocante aos termos entradas e bandeiras, a historiografia tradicional adota duas posições. Uma que engloba na designação bandeiras todas as expedições que incursionavam pelo sertão, partindo de qualquer ponto do Brasil e formadas de iniciativa oficial ou particular. A outra corrente

\footnotetext{
${ }^{13}$ MOURA, Gentil de Assis. "As Bandeiras Paulistas: estabelecimentos das diretrizes gerais a que obedecem e estudo das zonas que alcançaram.” In: R.I.H.G.S.P. Vol. XIX. São Paulo: Typographia do Diário Oficial, 1915. p. 75-76.

${ }^{14}$ Cf. ELLIS JR., Alfredo. O Bandeirismo Paulista e o Recuo do Meridiano. $2^{\mathrm{a}}$. ed. São Paulo: Companhia Editora Nacional, 1934.

${ }^{15}$ VOLPATO, Luiza Rios Ricci. Entradas e Bandeiras. São Paulo: Global, 1985. p. 57.

${ }^{16}$ MAGALHÃES, Basílio de. Op. cit.

${ }^{17}$ Cf. FAORO, Raymundo. Os Donos do Poder. Volume I. Porto Alegre: Globo, 1984.

${ }^{18}$ LUÍS, Washington. Na Capitania de São Vicente. Belo Horizonte-São Paulo: Itatiaia-Edusp, 1980. p. 188.

${ }^{19}$ Cf. Inventário de Maria de Unhate Madurga (1701). Cx. 1700-1703. A.H.M.T.
} 
limita a aplicação do termo entradas às expedições inspiradas pelos representantes da Coroa, e reserva apenas aos grupos paulistas, de formação espontânea, a nome bandeiras. ${ }^{20}$

Note-se, agora, que uma das determinantes é a regionalidade. Brasil de um lado e São Paulo de outro, como se fossem realidades bem distintas. ${ }^{21}$ Aliás, a diferenciação também fez com que se formulassem "ciclos". Novamente Basílio de Magalhães é lembrado. Para ele houve o ciclo das entradas e o das bandeiras; o primeiro comandado oficialmente pela Coroa e o segundo espontaneamente por particulares (excepcionalmente pelos paulistas). Dentro do segundo ciclo, continua Magalhães, havia as subdivisões: o ciclo do ouro de lavagem (metade do século XVII no litoral), o da caça ao índio (apogeu entre 1628 e 1680) e, por fim, o grande ciclo do ouro (início em 1693). ${ }^{22}$

É muito comum entre os pesquisadores esta tendência para a demarcação cronológica assentada nos objetivos das expedições, objetivos, aliás, que fizeram Cassiano Ricardo pensar em "bandeiras de conquistar o chão" e "bandeiras de conquistar almas". 23 Sobre tal cronologia assinala José Bernardo Ortiz que o bandeirismo, no caso o paulista, “iniciado em meados do quinhentismo, foi até cerca de 1690 essencialmente desbravador e voltado para a caça do índio" 24 , anulando desta maneira qualquer noção de processo histórico referente à exploração mineral anterior à descoberta oficial de ouro que se deu justamente na última década do século XVII. Ao contrário disso, acredita-se que não seja possível distinguir claramente os objetivos das bandeiras em ciclos ou períodos, mesmo porque uma vez no sertão os colonos visavam obter vantagens que, de fato, compensassem todos os esforços empregados, seja via apresamento indígena (coisa mais comum e mais ao alcance deles), seja via exploração dos metais e pedras preciosas (o que era mais difícil de acontecer, mas não impossível). Então, assim como para Pandiá Calógeras, entende-se que

\footnotetext{
${ }^{20}$ DAVIDOFF, Carlos Henrique. Bandeirantismo: verso e reverso. São Paulo: Brasiliense, 1982. p. 26-27.

${ }^{21}$ Esta questão será melhor trabalhada adiante.

22 MAGALHÃES, Basílio de. Op. cit. Cf. também do mesmo autor "O Bandeirismo no Brasil: subsídios para o estudo desse importante fenômeno da nossa evolução." In: R.I.H.G.B. Tomo LXXVII, Rio de Janeiro: Typographia Universal de Laemmert, 1915. p. 74.

${ }^{23}$ RICARDO, Cassiano. Marcha para o Oeste. Rio de Janeiro: Livraria José Olympio Editora, 1959. p. 132 e segs.

${ }^{24}$ ORTIZ, José Bernardo. São Francisco das Chagas de Taubaté. Tomo II. Taubaté: Prefeitura Municipal de Taubaté, 1996. p. 276.
} 
havia uma aproximação nas intenções das bandeiras, isto é, caça de índios e pesquisa mineral podiam conviver juntas na mesma empresa. ${ }^{25}$

O tamanho dos empreendimentos sertanistas também foi utilizado como parâmetro de classificação. Nesse sentido, entradas eram penetrações pequenas, de baixa envergadura, e as bandeiras eram expedições de maior porte. ${ }^{26}$ Faz parte ainda deste critério as chamadas "armações" que estavam entre as expedições menores destinadas apenas a reprodução das próprias unidades produtivas através da obtenção de silvícolas que eram a força coletiva de trabalho em ampla exploração. ${ }^{27}$

Por fim, há também uma tendência em se fazer a diferenciação por meio das características encontradas no comportamento das expedições. Ellis Jr. separa as bandeiras do século XVII das do XVIII. As primeiras, destinadas a caça do índio, eram expedições bélicas, já as seguintes, que buscavam ouro, eram essencialmente empresas comerciais. Tais mudanças, segundo o autor, também ocorreram nas relações sociais dentro das próprias bandeiras, visto que de um negócio comunitário passou a ser particularista. ${ }^{28}$

Devido a este emaranhado de opiniões é necessário definir melhor o objeto que se pretende analisar na presente dissertação. De imediato, preferiu-se não fazer distinção entre bandeiras e entradas sertanistas, da mesma forma quanto aos termos bandeirantes e sertanistas, visto que ambos se referem às ações de adentrar ao sertão e aos indivíduos que as exerceram, tanto em diferentes pontos geográficos quanto ao longo do tempo. Logicamente que se tem ciência de que é possível que houvesse algum tipo de classificação, porém, ao que tudo indica, a nomenclatura destinada a um ou a outro modelo de expedição ampliou seu quadro de referências, sendo utilizado como significado comum, isto é, os termos em questão popularizaram-se a nível de sofrer esvaziamento de

${ }^{25}$ Cf. CALÓGERAS, João Pandiá. As Minas do Brasil e sua Legislação. Rio de Janeiro: Imprensa Nacional, 1904. p. 33. Para Cunha Lima é de se crer que, além de caça ao índio, "os bandeirantes também se dedicassem à exploração da terra à procura do ouro." LIMA, J. A. Cunha. "As Descobertas do Ouro e o Regime Jurídico e Administrativo das Minas." In: Revista do Arquivo Municipal. Vol. CLXXI. Ano XXIX. p. 72.

${ }^{26}$ Cf. ORTIZ, José Bernardo. Op. cit. p. 271.

${ }^{27}$ Cf. MONTEIRO, John Manuel. Negros da Terra: índios e bandeirantes nas origens de São Paulo. São Paulo: Companhia das Letras, 1994. p. 85.

${ }^{28}$ ELLIS JR., Alfredo. Raça de Gigantes: a civilização no planalto paulista. São Paulo: Editora Helios Limitada, 1926. p. 286. 
significados mais específicos, como se fez notar pela diversidade de termos usados: entrada, bandeira, viagem, descobrimento, jornada, carregação, etc.

Se em princípios da colonização portuguesa na América as expedições com vistas ao reconhecimento e ao combate contra os indígenas eram quase que exclusivamente organizadas pelo poder oficial e de cunho basicamente militar, tempos depois esta configuração sofreu mudanças, sendo acrescentadas intenções econômicas e maior envolvimento de particulares. As mutações eram comuns e faziam parte da própria dinâmica da Colônia, e neste processo de constantes readaptações seria um erro querer traduzir num termo ou noutro uma prática que perdurou durante alguns séculos e que viu sua essência se transformar de acordo com as multi-realidades existentes. Nesse sentido, bandeirismo ou sertanismo serão tomados, aqui, como sinônimos das atividades voltadas ao sertão, isto é, dos esforços particulares ou oficiais, com objetivos de apresamento e/ou prospecção, de menor ou maior envergadura e efetuadas em qualquer região do Brasil.

Definido o objeto de estudo passa-se agora a discorrer sobre a especialização do paulista nas atividades sertanistas, situação esta que chamou a atenção de muitos estudiosos que, durante longo tempo, buscaram explicá-la.

Antes de qualquer argumentação, achou-se muito útil iniciar a reflexão partindo das palavras de Washington Luís. Entende ele que

tendo sido, em todas as Américas, idênticos os métodos e análogos os processos de devassar, apossear a terra, foram em S. Paulo que se organizaram as maiores e as mais numerosas bandeiras, e, por isso, bandeira tornou-se nome local e bandeirante ficou sinônimo de homem paulista. Mas nelas tomaram parte homens das outras vilas da capitania, das outras capitanias e da metrópole. ${ }^{29}$

Ora, se as bandeiras foram praticadas em diversas localidades, então, por qual razão os paulistas tiveram a fama de serem os mais experientes e os mais bem preparados para as adversidades do sertão? Esta questão se tornou o fio condutor de inúmeros estudos que inundaram, principalmente, a primeira metade do século XX. Muitas teses foram elaboradas sob os mais variados pontos de vista, todas, no entanto, contribuíram para a consolidação de uma imagem histórica de São Paulo colonial, imagem que perdura até os dias atuais não obstante os estudos revisionistas que estão em pauta. Torna-se importante,

\footnotetext{
${ }^{29}$ LUÍS, Washington. Op. cit. p. 186-187.
} 
por isso mesmo, expor aqui as hipóteses levantadas pela historiografia a fim de compreender a própria trajetória do assunto no meio acadêmico.

De fato, a colonização portuguesa na região sul do Brasil, algo que hoje seria o Sudeste e Sul, se processou em moldes diferenciados. Tanto em termos sociais, econômicos e políticos, o quadro existente era particular. No entanto, há que se ter noção da mutação e adaptação das realidades presentes no imenso Império português, o que quer dizer que as próprias diferenças faziam parte da sobrevivência do sistema de colonização e exploração. Logo, não é de se estranhar certas especificidades de São Paulo. Mas no início do século $\mathrm{XX}$, isso tudo causava euforia entre os interessados no assunto. Para eles, o estabelecimento de Piratininga, por exemplo, já na era de 1530, constituía uma vitória sobre a mata e "deste avanço procede o desenvolvimento peculiar de São Paulo."30 Diante de uma situação de extrema proximidade com o sertão a região tornou-se inevitavelmente uma "comarca das bandeiras." 31 Assim, nasceu com propósitos sertanistas de "ocorrência singular na América do Sul, tão específica, tão original que se nega às explicações, permanecendo fechada no segredo de sua tipicidade." 32

Uma das principais explicações para a sobreposição dos paulistas no contato com o sertão estava em sua formação racial. Vale lembrar que esta linha de pensamento, desde o século XIX até as primeiras décadas do XX, teve grande aceitação no meio acadêmico, norteando muitas pesquisas históricas. Dessa maneira, buscou-se entender como e porquê São Paulo se tornou a "pátria" de homens diferenciados, cujas especificidades lhe garantiram o título de "raça de gigantes" dado por Saint-Hilaire e que foi muitas vezes lembrado com exaltação pelos estudiosos. ${ }^{33}$

Alfredo Ellis Júnior foi, talvez, o principal representante destes estudos raciais. Intelectualmente, destacou-se pelo tom polêmico de suas teses que procuravam glorificar as origens paulistas. Lançando mão de teorias evolucionistas, de determinismo racial e físico, esforçou-se para dar bases científicas e históricas à exclusividade observada apenas em São Paulo frente ao resto do Brasil. Para ele, o motivo de tudo isso era, sem dúvida, a origem sócio-racial dos europeus e sua feliz mestiçagem com o elemento indígena. Entende que

\footnotetext{
${ }^{30}$ ABREU, Capistrano de. Op. cit. p. 127.

${ }^{31}$ ZENHA, Edmundo. Mamelucos. São Paulo: Empresa Gráfica da Revista dos Tribunais, 1970. p. 75.

${ }^{32}$ Idem, Ibidem. p. 99.

${ }^{33}$ Cf. SAINT-HILAIRE, Augustin. Viagem a Província de São Paulo. São Paulo: Itatiaia, 1976.
} 
"os povoadores ibéricos, que nos dois primeiros séculos iniciaram a população planaltina da capitania de São Vicente, foram indivíduos da elite mais apurada, e dotados de todos os recursos humanos para vencer na empreitada a que se propuseram"34, sendo que a forte ligação com os silvícolas possibilitou a formação de uma "sub-raça" chamada paulista, "os coeficentes causadores da grandeza dos feitos dessa, que Saint-Hilaire apelidou de 'raça de gigantes" ${ }^{\prime 35}$, mesmo porque somente pessoas desta estirpe tinham condições para atuar nos empreendimentos sertanistas.

Se Ellis Jr. defende a vinda de uma elite européia para São Paulo, Washington Luís acredita que, "se aqui tivessem ficado os fidalgos de linhagem, imbuídos de preconceitos de cor e de raça, amolecidos pelo viver na corte, ou habituados a serem obedecidos nos seus morgadios, não haveria Brasil". ${ }^{36} \mathrm{E}$ mais, continua o autor, "só essa gente rude, que ficou para mestiçagem, poderia deixar aos seus descendentes o nome de bandeirantes. Só os seus descendentes imediatos, os meio-sangues, os mamelucos, como injusta e desprezivelmente eram conhecidos, poderiam afrontar e vencer as agruras do sertão. ${ }^{„ 37}$ Logo, a origem dos colonos, de um lado nobre e de outro rude, era o fator determinante para o sucesso dos paulistas. Portanto, “o resultado do cruzamento desse povo [índígena] com o europeu foi o mameluco, um tipo especial de homem, eugênico, sarado de corpo e espírito, pura força da natureza." 38

Há quem defenda, também, a existência entre os colonizadores europeus das terras paulistas de uma "têmpera indomável" que com "determinação e coragem começaram a

${ }^{34}$ ELLIS JR., Alfredo. Raça de Gigantes: a civilização no planalto paulista. São Paulo: Editora Helios Limitada, 1926. p. 75.

${ }^{35}$ Idem, Ibidem. p. 88.

${ }^{36}$ LUÍS, Washington. Op. cit. p. 57.

${ }^{37}$ Idem, Ibidem. p. 57. De forma mais detalhada, assim atribui as vantagens raciais dos mamelucos paulistas: "Com o cruzamento das duas raças, apareceram os mamelucos que herdaram dos pais uma intelegência mais apurada, a iniciativa e a tenacidade nos esforços, as possibilidades da civilização, aprenderam a língua portuguesa e foram feitos cristãos; das mães herdaram a resistência física às agruras do viver sem conforto, a sobriedade na qual o comer não tinha horas marcadas, e, às vezes, nem havia o que comer. Herdaram mais a imunidade às febres, conseguiram a adaptação ao clima áspero e selvagem do sertão falto de todo o necessário, mas abundante de feras, de mosquitos, que dão febres, que herdaram também os ódios de tribos, e, por consequência, o gosto indômito de guerrear. Foram eles, foram esses mamelucos, os elementos básicos, indispensáveis para a organização das bandeiras e decisivos para o bom êxito das entradas ao sertão, concorrendo poderosamente para a conquista e povoação do interior do Brasil." Idem, Ibidem. p. 174-175.

${ }^{38}$ ZENHA, Edmundo. Op. cit. p. 270. 
construir um imenso País" por meio do desbravamento dos sertões. ${ }^{39}$ Houve autor que chegou a fazer a comparação entre os bandeirantes e os antigos gregos. O Dr. Artur Orlando, em artigo publicado na Revista do Instituto Histórico, Geográfico de São Paulo, datado do ano de 1912, defende que "o bandeirante reproduz o mesmo tipo de aventureiro grego a correr atrás do escravo e do velocino de ouro.” Explica Orlando que

o estudo dos bandeirantes mostra que, apesar da diferença de raça, de religião, de cultura, de tradições, em poucas palavras, de tudo que se refere ao elemento humano, dadas as mesmas condições de apropriação e produção do solo, surge um tipo social, que não é senão a reprodução de tipos anteriores, sempre idênticos entre povos, que se acham nas mesmas circunstâncias de ocupação e exploração da terra. (...) Assim, é que, em épocas bem distantes e em regiões bem diversas, vemos o bandeirante reproduzir o mesmo tipo do aventureiro grego. ${ }^{40}$

Como se fez notar, as teses sobre as causas do bandeirismo paulista, em princípio, estavam assentadas nas origens raciais, variando entre uma ascendência nobre ou rude, mas que de qualquer forma deu o passo inicial para a construção da grandeza do paulista ao se miscigenar com a população silvícola, cruzamento do qual surgiu o "inigualável” mameluco.

Ainda em termos de configuração física, outras determinantes costumeiramente apresentadas eram o clima e a geografia espacial. A junção do elemento europeu, indígena e as condições climáticas e geográficas seria, como acredita Myriam Ellis, filha de Alfredo Ellis Jr., o motivo que favoreceu a constituição do bandeirante paulista. ${ }^{41}$ Assim como esta autora, Edmundo Zenha ressalta que "o ótimo geográfico e, com ele, um processo de fusão de raças também em condições de ótimo eugênico, tudo favorecido por clima excepcional, produziram uma população surpreendente, dotada de força expansiva que dificilmente encontraria resistência." 42

Simbiose racial e determinismo climatológico eram, enfim, o que inspiravam as condições históricas específicas de São Paulo. Tudo isso, em conjunto, teria influenciado o espírito de seus habitantes, dando a eles aquilo que não havia em nenhuma outra população

\footnotetext{
39 ORTIZ, José Bernardo. São Francisco das Chagas de Taubaté. Tomo I. Taubaté: Prefeitura Municipal de Taubaté, 1996. p. 489.

${ }^{40}$ ORLANDO, Artur. "Bandeirantes”. In: R.I.H.G.S.P. Volume XIV. São Paulo: Typographia do Diário Oficial, 1912. p. 134-135.

${ }^{41}$ Cf. ELLIS, Myriam. Op. cit.

${ }^{42}$ ZENHA, Edmundo. Op. cit. p. 99.
} 
do Brasil: um espírito bandeirante, vanguardista. Este espírito teria, assim, guiado as ações dos paulistas, inclusive nas incursões ao sertão. Seja por razões econômicas, seja por razões sociais, religiosas, ou mesmo apenas por simples demonstração de bravura e coragem, as bandeiras foram uma resposta à pré-disposição espiritual de seus participantes.

Por muito tempo se cogitou que as bandeiras ocorreram devido ao isolamento reservado a São Paulo e a sua consequente marginalização dentro do sistema de exploração colonial. Se por um lado este quadro deu à região um estado negativo, visto que não proporcionava o desenvolvimento da exploração - principalmente agrária - e, por isso mesmo, forçou seus moradores a ir ao sertão buscar "seu remédio" devido sua extrema pobreza, por outro atuou de forma positiva na configuração de seu espírito democrático, corajoso, valente, audacioso, independente e tenaz lutador. ${ }^{43}$

Existem autores que acreditam terem sido as bandeiras inspiradas pela cobiça. Assim define, por exemplo, Vianna Moog: “Cobiça e luxúria, caça ao índio e caça à fêmea, em constantes reproduções sul-americanas do episódio do rapto das sabinas, eis no plano ético a síntese da história das bandeiras." ${ }^{44}$ Há também quem defenda que as incursões sertanistas foram causas imediatas da necessidade dos nobres de São Paulo em manterem seu status. Segue aqui um trecho do texto de Manoel Rodrigues Ferreira. Diz ele: “Os bandeirantes eram da nobreza, e não da classe dos oficiais mecânicos.” E se pergunta, "por que razão?" Pois bem, "lutando para que tanto eles, como seus filhos, não descessem à condição de oficiais mecânicos, os nobres procuravam no sertão, os índios que iriam trabalhar nas suas fazendas, e os minerais preciosos que lhes proporcionariam o cabedal necessário para continuarem a viver à lei da nobreza." Portanto, "se não existisse essa condição de nobre, com toda a certeza não teriam existido as bandeiras." ${ }^{45}$ Ora, como pôde ser a atividade sertanista, isto é, a prática de adentrar os sertões atrás de mão-de-obra e riquezas minerais um exercício de nobreza? Passar longo tempo no mato sob condições de

\footnotetext{
${ }^{43}$ Sobre a tese da fraca produção agrária em São Paulo Cf. ZEMELLA, Mafalda P. Abastecimento da Capitania das Minas Gerais no século XVIII. São Paulo: Hucitec: Editora da USP, $2^{\mathrm{a}}$ Edição, 1990; Já sobre a formação de uma sociedade democrática, independente e lutadora Cf. ELLIS, Myriam. Op. cit.

${ }^{44}$ MOOG, Clodomir Vianna. Bandeirantes e Pioneiros: paralelo entre duas culturas. $10^{\mathrm{a}}$. ed. Porto Alegre: Editora Globo, 1973. p. 110.

45 FERREIRA, Manoel Rodrigues. "História Político-Social de São Paulo.” In: FERREIRA, Tito Lívio; FERREIRA, Manoel Rodrigues. História da Civilização Brasileira. São Paulo: Editora Gráfica Biblos, 1959. p. 344-345.
} 
extrema dificuldade, em situações nada confortáveis era o suficiente para imprimir um status de nobreza? Se assim fosse, grande parte da sociedade paulista seria nobre. É, pois, inviável aderir a esta teoria porque ao eleger somente o fator "social" - em termos de manutenção de um status quase que fictício para o contexto analisado - como elemento único fomentador na execução das bandeiras tal pensamento exclui questões de maior relevância como, por exemplo, as características da economia local e a tipicidade da exploração colonial para a região.

Há quem atribua às bandeiras uma "missão superior." Para João de Scantimburgo "no fundo de cada luso-brasileiro palpitava a missão de Portugal, a dilatação da fé e do Império. Foi essa a origem do movimento bandeirante". ${ }^{46}$ Por outras palavras, as ações de devassamento do sertão foram impulsionadas por uma consciência que lembrava cada colono da sua obrigação enquanto cristão e vassalo, assim todo e qualquer esforço representava única e exclusivamente os interesses externos à realidade local. De maneira enfática, continua o autor:

defendo as bandeiras, essa majestosa epopéia, refutando a tese do exclusivo interesse econômico, o preamento de índios e a cobiça de supostos tesouros, que o ouro do Peru sugeriria aos bandeirantes. Armados de uma grande missão, a de dilatarem o Império português e a de levarem os missionários com a fé para o interior os bandeirantes a cumpriram. ${ }^{47}$

Além desta conotação religiosa, as bandeiras operavam num sentido extremamente político, como salientou o autor ao dar a seus participantes uma noção de cumprimento abstrato dos deveres inerentes a cada vassalo português, porém não questionou a intensidade desta consciência e o seu nível de interferência no cotidiano das pessoas. Aliás, ao mesmo tempo que Scantimburgo atribui essa concepção extrema de alinhamento dos interesses entre colono e Coroa direcionado a um fim maior, qual seja, a expansão da fé cristã e do Império, também salienta a formação de um "ardor patriótico" que acabou por construir "nos trópicos uma grande nação, o Brasil", ainda no período colonial. ${ }^{48}$ Ora, as bandeiras e os colonos que nelas estavam cumpriram uma missão acima de qualquer interesse pessoal e local fomentados por um "inconsciente coletivo" que tomava a expansão

\footnotetext{
${ }^{46}$ SCANTIMBURGO, João de. Os Paulistas. São Paulo: Imprensa Oficial do Estado de São Paulo, 2006. p. 103.

${ }^{47}$ Idem, Ibidem. p. 14.

${ }^{48}$ Idem, Ibidem. p. 60.
} 
espiritual e imperial como objetivo a ser cumprido, ou pairava sobre os colonos paulistas, essa "raça de gigantes", uma intenção deliberada e ciente voltada para a construção de uma nova pátria, o que denotaria, obviamente, um desacordo de interesses, uma falta de vínculos entre colônia e metrópole? Bem, este autor defende, estranhamente, os dois lados da moeda. Não há um meio termo, não há uma contextualização histórica, não há uma tentativa de aproximação com as articulações políticas, econômicas, sociais e religiosas que, como se sabe, conviviam conjuntamente e faziam parte da realidade, muitas vezes se contradizendo.

Tocando no tema dos objetivos políticos e do expansionismo do Império português, outro ponto muito usado para se explicar as causas do bandeirismo paulista foi a conquista territorial. Um dos maiores representantes deste ponto de vista foi o historiador português Jaime Cortesão. Para ele, as bandeiras estavam envoltas numa dimensão geopolítica sempre com vistas à expansão dos limites territoriais que cabiam a Portugal na América. Apesar de ainda manter uma tendência à glorificação da figura do bandeirante, Cortesão apontou para o que chamou de "cultura geográfica" indígena, isto é, a acumulação de conhecimentos topográficos adquirida pelos ameríndios durante muito tempo através do contato com o interior do continente, e lembrou que tal entendimento foi constantemente transferido para o colono europeu que soube utilizá-lo nas conquistas do interior. ${ }^{49}$ Para Vianna Moog, o Brasil foi obra do bandeirante que, apesar da cobiça, ofereceu "o bem inestimável da ampliação do território nacional para muito além dos limites que lhe haviam sido designados pelo tratado das Tordesilhas", um esforço que "não é pequeno". 50

Essa linha de raciocínio foi bastante aceita, muitos foram os estudiosos que a adotaram. Violentas ou não, ilegais ou não, nada pode tirar o brilho das conquistas sertanistas. Até se pesou na balança as vantagens e desvantagens. Capistrano de Abreu, após descrever as atrocidades que os paulistas cometeram contra os índios aldeados, se questionou: “Compensará tais horrores a consideração de que por favor dos bandeirantes pertencem agora ao Brasil as terras devastadas?"51 Belmonte não exita em dizer que os bandeirantes, esses "ciclópicos sertanistas", numa "forja de Titãs, que se vão formando os

\footnotetext{
${ }^{49}$ Cf. CORTESÃO, Jaime. Raposo Tavares e a Formação Territorial do Brasil. Rio de Janeiro: Imprensa Nacional, 1958. p. 15-18.

${ }^{50}$ MOOG, Clodomir Vianna. Op. cit. p. XIV e 166.

${ }^{51}$ ABREU, Capistrano. Op.cit. p. 131.
} 
gigantes que, em embates violentos, vão impelindo para longe, até os contrafortes dos Andes, a muralha de Tordesilhas." ${ }^{, 52}$ Referindo-se às bandeiras, menciona também José Felício Buarque de Macedo: “esse episódio da história territorial do Brasil, em que rebrilha a atividade patriótica de ousados aventureiros na dilatação do nosso território, em caça de índios e descoberta de minas." 53 Cobiça, nacionalismo, heroísmo e atrocidades fazem, assim, parte de um todo.

Como foi visto até aqui o bandeirismo paulista foi analisado sob diversas vertentes ao longo de muito tempo. Tem-se ideias elaboradas desde os fins do século XIX até as últimas décadas do XX, muitas delas não se sustentaram e outras se mantêm firmes e fortes na concepção histórica sobre São Paulo.

A trajetória destes estudos foi profundamente marcada pelas intenções contextuais em que estavam inseridas, ou seja, cada tese carrega em si a materialização das forças sociais, econômicas e políticas de sua época. Por isso é importante ter em mente o papel da historiografia em um dado momento, seja objetivamente ou subjetivamente. De maneira simplificada, os estudos históricos de São Paulo colonial e do bandeirismo foram marcados por dois momentos: o primeiro durante as primeiras décadas do século $\mathrm{XX}$ através da historiografia chamada de "paulística", e o segundo nos anos após $1950 .^{54}$

Ilana Blaj, responsável por uma das análises mais completas da historiografia sobre São Paulo, assim resume o tema:

A partir da historiografia 'paulística', vinculada ao Instituto Histórico e
Geográfico de São Paulo, algumas imagens a respeito de São Paulo
colonial foram sendo cristalizadas. Com efeito, tal historiografia tinha
como construção implícita, a preocupação de justificar o poder de São
Paulo no contexto de riqueza cafeicultora no âmbito da Republica Velha,
o que pressupunha um relacionamento com os outros Estados e a luta
pela hegemonia nacional. As imagens a partir daí resultantes edificam um
paulista altivo, independente, arrojado e leal, cuja síntese seria o
bandeirante.

\footnotetext{
${ }^{52}$ BELMONTE. No Tempo dos Bandeirantes. São Paulo: Governo do Estado, 1980. p. 150 e 274.

${ }^{53}$ MACEDO, José Felício Buarque de. "Ação das Bandeiras.” In: R.I.H.G.S.P. Volume XIV. São Paulo: Typographia do Diário Oficial, 1912. p. 326.

${ }^{54}$ Para maiores informações sobre as tendências historiográficas. Cf. IGLÉSIAS, Francisco. Os Historiadores do Brasil: capítulos de historiografia brasileira. Rio de Janeiro: Nova Fronteira; Belo Horizonte: UFMG, IPEA, 2000.

${ }^{55}$ BLAJ, Ilana. "Mentalidade e Sociedade: revisitando a historiografia sobre São Paulo colonial." In: Revista História. São Paulo. nº 142-143, 2000. p. 240.
} 
Após esta explanação fica claro o uso da História como ferramenta política. Assim, percebe-se que a figura do bandeirante e o seu "habitat" foram, em muitos casos, construídos sob influência de objetivos externos canalizados pela subjetividade do estudioso. Logo, aquilo que seria negativo tornou-se vantajoso: isolamento e pobreza não impediram os paulistas de serem audaciosos, aventureiros, independentes, democráticos, altivos, nobres, promotores da expansão territorial e da integração nacional e até mesmo leal servidores do rei de Portugal. Esta era a imagem do bandeirante, agora transformado em símbolo paulista representativo da sua própria identidade seja qual for a época, inclusive em momentos de conflito como o da República Velha e o da Revolução Constitucionalista de $1932 .^{56}$

O segundo bloco de análise pode ser observado após a década de 1950 que é quando os estudos se direcionam para o entendimento da posição mundial em que se encontrava o Brasil, o já extinto título de "terceiro-mundo". Em comparação aos grandes países, principalmente aos Estados Unidos, por qual motivo o Brasil não teve igual evolução? Partindo desta indagação, os especialistas foram buscar no passado a explicação para tal quadro. Dessa forma, o passado colonial e a exploração do Brasil foram intensamente avaliados, elegendo-se como modelo histórico desta fase o Nordeste açucareiro, logo, São Paulo foi relegado ao segundo plano. Esta tendência fez com que se confirmasse cada vez mais a imagem montada sobre o paulista, concluindo-se que São Paulo apresentava uma “formação peculiar, atípica, diferenciada com relação às áreas exportadoras escravistas",57, e por tudo isso o bandeirismo encontrou aí a sua melhor adaptação.

Enfim, economia, religião, sociedade, política, geografia, ética e raça foram os caminhos trilhados a fim de se explicar a especialização do paulista nos assuntos do sertão. Cada vertente destas contribuiu para o progresso do conhecimento histórico de São Paulo. Atualmente, porém, novos pontos de vista estão surgindo e muitos deles retificam antigas concepções.

Aliás, ainda por volta de meados do século passado, os escritos de Sérgio Buarque de Holanda apresentaram um desenvolvimento interpretativo inovador quanto a história de

\footnotetext{
${ }^{56}$ Cf. BLAJ, Ilana. A Trama das Tensões: o processo de mercantilização de São Paulo colonial (1681-1721). São Paulo: Humanitas/FFLCH/USP: Fapesp, 2002. Ver principalmente o capítulo 1, "A construção das imagens."

${ }^{57}$ BLAJ, Ilana. "Mentalidade e Sociedade...”. p. 242.
} 
São Paulo colonial. Com a publicação de Monções e Caminhos e Fronteiras, esse historiador procurou rebater justamente a imagem do paulista isolado e atípico em relação ao resto do Brasil. Sobre a especificidade da região, incluindo a prática sertanista, propôs uma análise que salientava a noção de que cada época e cada região têm seu próprio centro de gravidade formado em virtude da interação entre o meio, a cultura e a sociedade. Holanda mostrou que, mesmo tendo uma configuração diferenciada, a área paulista fazia parte do conjunto estrutural da colônia. Entretanto, as palavras de Holanda não ganharam tanto espaço entre os estudiosos. Foi preciso chegar a década de 1980 para o tema voltar à tona.

Em pequeno livro, mas não menos importante, intitulado Bandeirismo: verso $e$ reverso, Carlos Davidoff inovou ao desmascarar a violência que sempre permeou as relações entre os paulistas e o gentio da terra. Porém grande parte do seu texto ainda reproduz visões tradicionais sobre São Paulo. Apesar disso, há uma equivalência entre a repetição de alguns argumentos e o avanço no entendimento do bandeirismo. Veja-se o que diz:

O bandeirante foi fruto de uma região marginalizada, de escassos recursos materiais e de vida econômica restrita, e suas ações se orientaram ou no sentido de tirar o máximo proveito das brechas que a economia colonial eventualmente oferecia para a efetivação de lucros rápidos e passageiros em conjunturas favoráveis - como no caso da caça ao índio - ou no sentido de buscar alternativas econômicas fora dos quadros da agricultura voltada para o mercado externo, como ocorreu com a busca dos metais e das pedras preciosas. ${ }^{58}$

Foi, todavia, com a obra de John Manuel Monteiro que a renovação mais profunda se deu. Lançando novo olhar sobre um tema já bastante analisado, este autor buscou dar outra roupagem para o fenômeno do bandeirismo paulista, para tanto se amparou em extenso corpo documental. Suas argumentações visaram definir o papel do bandeirismo como ação que procurava sustentar a crescente economia de São Paulo ao oferecer constantemente mão-de-obra escrava para a produção agrária e pecuária. Assim resume Monteiro:

O ponto de partida é a simples constatação de que as frequentes incursões ao interior, em vez de abastecerem um suposto mercado de escravos índios no litoral, alimentavam uma crescente força de trabalho indígena no planalto, possibilitando a produção e o transporte de

${ }^{58}$ DAVIDOFF, Carlos Henrique. Op. cit. p. 25-26. 
excedentes agrícolas; assim, articulava-se a região da chamada Serra Acima a outras partes da colônia portuguesa e mesmo ao circuito mercantil do Atlântico meridional. ${ }^{59}$

Somente após lançar mão de toda essa recente abordagem, o autor pôde concluir que "apesar dos pretextos e resultados variados que marcaram a trajetória das expedições, a penetração dos sertões sempre girou em torno do mesmo motivo básico: a necessidade crônica de mão-de-obra indígena para tocar os empreendimentos agrícolas dos paulistas."60

O valor da análise de John Monteiro fica por conta de sua abordagem feita por uma perspectiva endógena, isto é, teve por objetivo situar o bandeirismo e a sociedade paulista dentro de um processo histórico específico em relação as outras regiões da colônia. Ao discorrer sobre as diversas restrições econômicas, demográficas e geográficas existentes na realidade do paulista procurou entender justamente as suas necessidades que, por sua vez, determinaram as suas ações e condutas. Assim, as bandeiras e o apresamento do índio passam a ser vistos como resultantes da própria dinâmica econômica e sócio-estrutural. E mais, o esforço dos colonos em manter o funcionamento da escravidão indígena, peça fundamental para a evolução produtiva da região, mostra o quanto se dependia desta instituição que, de fato, era o elemento de ligação com o sistema colonial de exploração, isto é, entende-se que, "a partir desta perspectiva, as estruturas que marcaram a sociedade colonial paulista não parecem tão distantes da sua contrapartida nas zonas açucareiras." ${ }^{\circ 1}$

Os novos apontamentos tendem a cada vez mais mostrar o Brasil como uma colônia em constante interação, onde diferentes regiões ligavam-se umas com as outras, cada qual com a sua especificidade mas sempre assentadas numa base única: a da estrutura sócioescravista. Aliás, este ponto é de suma importância para a avaliação dos paulistas, inclusive dos bandeirantes. Deve-se considerar as diferenças existentes que estavam distribuídas ao longo da extensa massa territorial do Brasil, diferenças estas observadas na eleição de certos produtos como sendo mais apropriados e nas práticas econômicas de maiores necessidades, todavia, como defende Ilana Blaj, havia uma unicidade estrutural na formação social brasileira. Por outras palavras: "a propriedade, a escravidão, os símbolos de prestígio e honrarias, constituem os fundamentos básicos da sociedade colonial

\footnotetext{
${ }^{59}$ MONTEIRO, John Manuel. Op. cit. p. 8.

${ }^{60}$ Idem, Ibidem. p. 57.

${ }^{61}$ Idem, Ibidem. p. 130.
} 
brasileira, com pecualiaridades específicas em todas as regiões, quer voltadas ao abastecimento interno como foi o caso de São Paulo." ${ }^{62}$ Nesse sentido, o paulista, máxime o bandeirante, não deve ser visto como uma "raça de gigantes", um povo "eleito", de qualidade superior, nascido para adentrar o sertão e pré-destinado a escrever na História seus grandes feitos. Portanto, o bandeirismo e seus atores serão tomados, aqui, apenas como colonos que, devido às circunstâncias materiais, encontraram nas incursões sertanistas uma saída para a montagem e manutenção da máquina de exploração colonial em São Paulo. Bandeirante passa a ser o colono que exercia economicamente uma função, a de caçar índio ou a de pesquisar a existência de metais e pedras preciosas.

Outro fator que deve ser destacado e que está entre os apontamentos feitos pela historiografia atual é a participação de São Paulo no sistema colonial de exploração e a sua interação tanto com outras localidades do Brasil como com a própria Metrópole. Nesse sentido, seria interessante questionar a "utilidade" do bandeirismo paulista no processo de colonização portuguesa e, com isso, verificar como se dava o relacionamento entre Coroa e vassalos dentro de um jogo de interesses, onde cada um dos lados agia a fim de conseguir a vantagem desejada.

\subsection{Bandeirismo Paulista: fama e utilidade.}

A Coroa portuguesa desde cedo direcionou parte de suas atenções para a região que mais tarde formaria a capitania paulista. Sem sombra de dúvida, já nos primeiros tempos da colonização, ela sabia que “a posição geográfica específica de São Paulo favorecia a situação de 'boca do sertão'.",63

De fato, parece ter havido uma relação entre tal vantagem no posicionamento geográfico da região e as primeiras medidas tomadas para a efetivação da colonização do Brasil, haja vista ter sido São Vicente a vila pioneira deste processo. Ora,

desde o início da colonização pensava-se que a capitania de São Vicente constituía um lugar privilegiado para a procura de ouro e Martim Afonso de Souza teria escolhido a região entre a ilha de São Vicente e o planalto de Piratininga para o estabelecimento dos primeiros núcleos de povoação porque se tratava da provável 'costa do ouro e da prata ${ }^{64}$

${ }^{62}$ BLAJ, Ilana. "Mentalidade e Sociedade..." Op. cit. p. 242-243.

${ }^{63}$ KOK, Glória Porto. Op. cit. p. 28.

${ }^{64}$ DAVIDOFF, Carlos Henrique. Op. cit. p. 65. Vale citar, aqui, uma carta do Padre Manoel da Nóbreza, infelizmente sem data, mas que comenta sobre o governo de Tomé de Souza (1549-1550) 
Noticia Frei Gaspar da Madre de Deus que Martim Afonso de Souza, em 1533, organizou uma bandeira destinada à procura de minas de ouro. Diz ele sobre o donatário: "a sua última ação memorável no Brasil teve por objeto o descobrimento de Minas”, pois “constando-lhe, por informação dos índios, que nas vizinhanças da Cananéia havia ouro, aprontou uma Bandeira de 80 homens e por eles mandou examinar o sítio indicado das Minas, mas com sucesso infeliz porque os bárbaros Carijós, senhores do país existente ao Sul do Rio da Cananéia, mataram os exploradores das minas, antes de as descobrirem.”, 65

Muitas foram as incursões sertanistas que partiram de São Paulo. Entende-se, assim, que a própria colonização da região foi assentada em pressupostos essencialmente ligados ao sertão e à procura de metais e pedras preciosas. Talvez esteja aí o germe da especialização dos paulistas na prática do bandeirismo. Logicamente que isso não foi tudo. Não obstante as condições materiais e culturais que favoreceram ao desenvolvimento das atividades sertanistas, há que se reconhecer o seu pontapé inicial, isto é, a familiaridade de São Paulo com o sertão começou logo cedo e com incentivo das autoridades portuguesas que, animadas devido "a vizinhança das riquíssimas minas de Potosi”, mandavam "expedições ao interior em busca do metal precioso.",66

É sabido que "corriam boatos sobre as potencialidades do sertão de São Paulo"67 e que "as histórias contadas pelos que retornavam do sertão serviam para aguçar a cobiça dos homens e fortalecer a crença de que tudo estava muito perto e que fortunas incalculáveis

e sobre a cristianização dos indígenas, destacando o papel da Capitania de São Vicente. Diz ele ao Rei D. João III: “(...) somente lhe darei alguma conta d'esta capitania de S. Vicente, onde a maior parte da Companhia residimos, por ser ela terra mais aparelhada para a conversão do gentio, que nenhuma das outras, porque nunca tiveram guerra com os cristãos, e é por aqui a porta e o caminho mais certo e seguro para entrar nas gerações do sertão, de que temos boas informações: há muitas gerações que não comem carne humana, as mulheres andam cobertas, não são cruéis em suas guerras, como estes da costa, porque somente se defendem; algumas têm um uso principal, e outras cousas, mui amigas da lei natural, por qual razão nos obriga Nosso Senhor a mais presto lhes socorrermos, maiormente que n'esta capitania nos proveu de instrumentos para isso, que são alguns irmãos línguas, e por estas razões n'esta capitania nos ocupamos mais que nas outras.” In: R.I.H.G.B. Tomo XLIII. Rio de Janeiro: Typographia Universal de Laemmert, 1880. p. 94-95.

${ }^{65}$ DEUS, Gaspar da Madre de (frei). Memórias para a história da Capitania de São Vicente hoje chamada de São Paulo e notícias dos anos em que se descobriu o Brasil. São Paulo: Martins Editora, 1953. p. 100.

${ }^{66}$ SOUZA, Laura de Mello e; BICALHO, Maria Fernanda Baptista. 1680-1720: o império deste mundo. São Paulo: Companhia das Letras, 2000. p. 22.

${ }^{67}$ Idem, Ibidem. p. 22. 
seriam logo atingidas." ${ }^{68} \mathrm{Na}$ verdade, foi justamente em território paulista que se concentrou a mais importante via da exploração mineira no Brasil. As pequenas faisqueiras que existiam não eram de grande vulto, todavia, "mais que as libras e oitavas, importam porém o gosto pelas pesquisas auríferas assim mantido e a prática do ouro de lavagem. Esta familiaridade influi de maneira benéfica sobre o desenvolvimento ulterior da mineração."69

De qualquer maneira, "eram os paulistas os únicos colonos com experiência mineira, pois, desde o século XVI, vinham explorando as minas dos arredores de São Paulo"70. Embora os minguados frutos dessas minas, muitas vezes aquém dos gastos dispendidos com a própria exploração, o importante é que elas existiam e isso era um avanço no processo de colonização do Brasil, em especial no diz respeito a São Paulo que cada vez mais se aproximava da órbita dos interesses da Coroa. Isto é tão certo que em fins do século XVI e início do XVII a atenção do principal representante do Rei no Brasil, o governador geral D. Francisco de Sousa, se voltou para o sul. Sérgio Buarque de Holanda é bem categórico quanto a isso: "não há melhor indício de que as jazidas de metal, embora pobres, eram aqui uma realidade, e capaz de impor-se à atenção dos agentes da Coroa.,"71

Reconhecidamente, a vinda de D. Francisco de Sousa a São Paulo é um fato bastante interessante, o que indica que a "Capitania de São Vicente fora visada pela Coroa de Castela desde os primeiros momentos da União.,"72 Aliás, em recente obra, Rafael Ruiz procurou mostrar a importância de São Paulo dentro dos planos da Espanha, que tencionava iniciar uma pesquisa de prospecção na região sul do Brasil e, para tanto, lançou mão de uma política de desenvolvimento econômico e demográfico, na qual São Paulo era a ponta de lança dos portugueses para o interior, como a porta de entrada para seu Império e ponto chave de defesa das Índias de Castela. ${ }^{73}$

No contexto da União Ibérica, houve um crescimento na atenção dada às terras dos paulistas por parte do poder oficial. Os boatos sobre a existência de minas de ouro e prata, a

\footnotetext{
${ }^{68}$ VOLPATO, Luiza Rios Ricci. Op. cit. p. 34.

${ }^{69}$ ABREU, Capistrano. Op. cit. p. 162.

${ }^{70}$ PINTO, Virgílio Noya. O Ouro Brasileiro e o Comércio Anglo-Português. São Paulo: Editora Nacional, 1979. p. 49.

${ }^{71}$ HOLANDA, Sérgio Buarque de. "A Mineração: antecedentes luso-brasileiros." In: História Geral da Civilização Brasileira. Tomo I. Vol. 2. Rio de Janeiro: Bertrand, 1989. p. 248.

${ }^{72}$ RUIZ, Rafael. São Paulo na Monarquia Hispânica. São Paulo: Instituto Brasileiro de Filosofia e Ciência Raimundo Lúlio (Ramon Llull), 2004. p. 59.

${ }^{73}$ Cf. Idem, Ibidem.
} 
familiaridade de seus habitantes com o sertão, a maior facilidade para as incursões sertanistas e as infrutíferas bandeiras que partiram da região nordeste, influenciaram no deslocamento de D. Francisco de Sousa para a região sul da colônia. Este governador trabalhou arduamente tanto em relação ao bandeirimo como na montagem de um aparato legal que sustentasse a mão-de-obra e a exploração das futuras minas. Nesse sentido, preocupou-se com a organização da força de trabalho, no caso a indígena, sob os mesmos moldes que a da América espanhola ${ }^{74}$, e com a legislação sobre as minas, que resultou no Regimento das Minas do Brasil, datado de 13 de agosto de $1603 .^{75}$

Tido como o "patriarca do bandeirismo", por receber "a glória de ser o propulsor inicial do movimento entradista paulistano"76, D. Francisco de Sousa não chegou a concretizar seus objetivos. A extensão do que realmente se efetivou na exploração do ouro de lavagem não se equiparou ao que foi prometido e o "tema das minas de São Paulo foi perdendo interesse ao longo do tempo. O consenso está na direção de que se tratou mais de uma obsessão, um sonho ou certos interesses políticos de D. Francisco e da própria Coroa."77 De fato, D. Francisco não achou o tão sonhado ouro que, ao fim, "foi a sua perdição."78

74 Para a Coroa de Castela "os índios eram livres, mas deviam trabalhar e, em prova do reconhecimento da sua liberdade, deviam receber um pagamento". Aqui, "estava sendo proposta uma estrutura análoga à castelhana. Estabelecia-se um sistema de 'repartimento de índios' do Brasil, para trabalhar a terra; e, com a finalidade de manter o princípio legal de liberdade, determinava-se que se pagasse aos indígenas, conforme a ficção jurídica já vinha sendo estabelecida pelos juristas castelhanos. (...) O problema, tal como ocorria no Peru e nos outros lugares da América espanhola, era saber se esse sistema de coerção legal com pagamento de salários seria o suficiente para fazer a terra, possivelmente porque os moradores não estavam dispostos ou não dispunham de quantia suficiente para pagar. Os moradores, e principalmente os paulistas, começarão em breve a utilizar do instituto legal da 'guerra justa' para conseguir uma mão-de-obra que não fosse necessário pagar.” RUIZ, Rafael. Op. cit. p. 98-99.

${ }^{75}$ O Regimento pode ser consultado na íntegra em LEME, Pedro Taques de Almeida Paes. Notícias das Minas de São Paulo e dos Sertões da mesma Capitania. São Paulo: Livraria Martins Editora, 1976. O principal destaque atribuído a tal regimento fica por conta da autorização para a exploração das minas dada aos colonos com a condição apenas de se pagar o quinto.

${ }^{76}$ TAUNAY, Affonso de E. História das Bandeiras Paulistas. São Paulo: Edições Melhoramentos, Tomo I, $2^{\text {a }}$ Edição, 1961. p. 16.

77 RUIZ, Rafael. Op. cit. p. 156. Para Davidoff, “apesar da pequena dimensão dos achados do período do ouro de lavagem, na capitania do sul, as pesquisas nos rios e nos sertões apresentaram razoável continuidade e na passagem do século XVI para o século XVII, o enviado real D. Francisco de Souza incentivou a pesquisa das minas e organizou a estrutura burocrática inicial da administração mineira, posteriormente modificada pela Metrópole.” DAVIDOFF, Carlos Henrique. Op. cit. p. 68.

${ }^{78}$ CALMON, Pedro. História do Brasil. Vol.II. 2a . Ed. Rio de Janeiro: José Olympio, 1963. p. 476. 
$\mathrm{Na}$ verdade seria um exagero dizer que após as investidas de D. Francisco e seu inesperado fracasso, o interesse pela descoberta dos metais preciosos tenha se perdido. $\mathrm{Na}$ pior das hipóteses ele apenas diminuiu. Outros representantes do poder real continuaram os trabalhos de pesquisa, inclusive com fortes ligações com a população paulista. Veja-se, por exemplo, o caso de Salvador Correa de Sá e Benevides, governador da Repartição do Sul. Oriundo de uma família com tradições sertanistas (sabe-se que Salvador de Sá, Martim e Gonçalo de Sá, seu avô, pai e tio, respectivamente, estiveram juntos em bandeiras) ${ }^{79}$, soube estreitar seus laços de interesses com os sertanistas de São Paulo, seja tratando de assuntos como a busca de ouro, seja na caça de índios. Charles R. Boxer, em monumental biografia, ressalta que "a julgar pela carreira feita depois por Salvador, parece provável que ele tinha despendido boa parte daqueles cinco anos (1615-1620) em entradas na Capitania de São Vicente, seja à caça de índios, seja na pesquisa de minas, em companhia dos paulistas." ${ }^{\prime 80}$

Apesar de todos os esforços empreendidos por diversos caminhos e direções, apesar das investidas feitas com ou sem o apoio dos paulistas, enfim, nem a Coroa portuguesa nem a espanhola obtiveram sucesso nas pesquisas minerais no Brasil de então. A situação até o fim da União Ibérica (1640) não havia mudado. Para Portugal, a falta de uma exploração sistemática de metais ou pedras preciosas em seu território americano era uma preocupação não somente em termos de obtenção de riquezas, mas também porque se deixava com isso de arrecadar impostos tão indispensáveis para a manuntenção de seu Império. Após 1640, a Coroa lusitana, triunfante no processo de Restauração, se encontrava submersa em problemas políticos, militares e, principalmente, financeiros, e a descoberta de riquezas minerais no Brasil tornava-se cada vez mais uma necessidade vital.

\subsection{Restauração Portuguesa e Crise Econômica}

A independência conquistada em 1640 deveria ser motivo para o reinício de uma vida próspera, livre do domínio espanhol, porém, a situação para Portugal e sua nova dinastia não começara muito bem. Avolumaram-se os problemas internos e externos que

\footnotetext{
${ }^{79}$ Pedro Calmon atribui ao governo de Salvador de Sá (Rio de Janeiro entre 1569-1572 e 15771599) um "sentido sertanista". Diz ele que Salvador "com Martim e Gonçalo de Sá, seus filhos, ampliou a conquista pelas montanhas adjacentes e através do vale do Paraíba, de maneira a não deixar índios hostis entre São Vicente e a Guanabara." Idem, Ibidem. p. 442.

${ }^{80}$ BOXER, Charles R. Salvador de Sá e a Luta pelo Brasil e Angola (1602-1686). São Paulo: Editora Nacional; Editora da USP, 1973. p. 54.
} 
acabaram por dificultar, de diversas maneiras, a consolidação da nova monarquia, além, é claro, de forçarem cada vez mais o declínio da já fraca economia portuguesa.

Para qualquer direção que se buscasse olhar era possível encontrar problemas. No entanto, parece ser o campo da economia o que mais sofreu nesse período. Vale lembrar que, se a conjuntura econômica de Portugal não ia muito bem, isso não quer dizer que fosse um caso isolado, ao contrário, ocorria naquele instante uma crise na economia européia que, logicamente, afetou mais gravemente os que possuíam uma estrutura já debilitada, que era o caso de Portugal. ${ }^{81}$ De qualquer forma:

a crise do metal precioso e a crise agrodemográfica, afetando quase todos os setores das atividades européias, provocaram a reversão do movimento secular mercantilista e precipitaram a recessão econômica, que se fez sentir desde meados do século XVII até início do século XVIII. ${ }^{82}$

Internamente, o reino estava, em sua totalidade, submerso num emaranhado de transtornos políticos, econômicos, sociais e militares. As palavras do Padre Antonio Vieira denunciavam as dificuldades enfrentadas naquele momento. Para ele os temas que mais mereciam atenção eram relacionados ao setor tributário, à produção de alimentos e ao perigo estrangeiro. ${ }^{83}$ Aliada à situação interna, o mundo colonial português também

${ }^{81}$ Para Fernando Novais, "na segunda metade do século XVII, debatia-se a economia portuguesa em grave depressão, aliás geral na Europa; o que os assessores da realeza de fato discutiam eram os tratos que a Restauração fora obrigada a fazer para defender-se da Espanha com concessões no mundo colonial, sobretudo à Inglaterra." NOVAIS, Fernando A. Portugal e Brasil na Crise do Antigo Sistema Colonial. 6a . ed. São Paulo: Editora Hucitec, 1995. p. 175-176.

${ }^{82}$ PINTO, Virgílio Noya. O Ouro Brasileiro e o Comércio Anglo-Português. São Paulo: Editora Nacional, 1979. p. 4. Para Boxer a crise à qual Portugal atravessava era conseqüência da "queda dos preços do açúcar e do fumo brasileiros e da elevação dos preços do trigo, dos tecidos e de outros artigos essenciais de importação, que vinham da Europa Setentrional." BOXER, Charles R. A Idade de Ouro do Brasil: dores de crescimento de uma sociedade colonial. $3^{\mathrm{a}}$. ed. Rio de Janeiro: Nova Fronteira, 2000. p. 47.

${ }^{83}$ Diz Vieira: “(...) considerando-se que o dinheiro com que o Reino serve e assiste a Vossa Majestade, não só não pode crescer mais, procedendo dos mesmos efeitos, mas cada vez será muito menor." E continua o padre: "porque as confiscações e cunho da moeda foram acidentes que se não podem repetir; as rendas e as comendas estão empenhadas para muitos dias e anos; os juros; as tenças e os salários não se pagam com um levantamento da moeda, que cresce o preço às mercadorias e faz que os estrangeiros tragam prata em vez de drogas, com que quebram muito os direitos das alfândegas; as terras das fronteiras, infestadas do inimigo, deixam de se cultivar por muitas léguas; as lavouras e as artes, levando-lhes os oficiais e lavradores para a guerra, se diminuem; o que tudo vai consumindo e atenuando as forças do Reino com passos largos, que em poucos anos não poderão os homens manter as vidas, quanto mais pagar os tributos e sustentar as despesas da guerra." VIEIRA, Pe. Antônio. "Proposta feita a el-rei d. João IV, em que se lhe 
declinava e, com isso, agravavam-se as condições de vida dos que viviam na metrópole e que dependiam, direta ou indiretamente, do comércio ultramarino.

É fato comumente conhecido que "Portugal encontrava-se bastante reduzido como potência colonial, quando recuperou sua independência em 1640." ${ }^{\text {, }}$ As atividades comerciais marítimas holandesas, francesas e inglesas surgiram como fortes concorrentes e acabaram por minar a hegemonia ultramarina lusitana. É nesse contexto que ocorreram as mudanças no quadro do Império português. Enquanto algumas de suas regiões perdiam importância, outras saltavam aos olhos da metrópole, com destaque à crescente atenção ao Brasil já que “(...) o refluxo do Império português no Oriente levava-o a entrincheirar-se no Atlântico sul, transformando-o num bastião ciosamente defendido e administrado." ${ }^{\circ 5}$

Desde o nascer do século XVII, o Brasil vinha se destacando como fonte de riqueza capaz de se equiparar com os frutos oriundos do Império Oriental, pois, enquanto a primeira crescia em produção, seguida pela lenta mas real estruturação político-fiscal, a segunda área de influência declinava em termos de rendimentos devido à perda do monopólio das rotas marítimas. Não por acaso “(...) o complexo açucareiro brasileiro, por volta da década de 1640, se tornara o coração do império português e a maior preocupação tanto para os habsburgos espanhóis, quanto para os bragancistas portugueses." ${ }^{86}$ Lembra-se ainda que a prosperidade do Brasil chamava a atenção de outras potências, em especial a dos holandeses que chegaram a ocupar de forma efetiva a área de maior produção açucareira do Brasil e, de quebra, também ocuparam Angola, importante região fornecedora de mão-de-obra escrava. ${ }^{87}$

Visando contornar a situação muita coisa foi feita logo após 1640 . Na tentativa de retomar o glorioso rumo, glória esta que esteve presente desde o início da expansão marítima portuguesa mas, que no século XVII, já não tinha mais a mesma aura, o recém-

representava o miserável estado do reino". Obras Escolhidas, vol. IV, Lisboa: Sá da Costa, s/d. p. 6-7.

${ }^{84}$ PINTO, Virgílio Noya. Op. cit. p. 5.

${ }^{85}$ MELLO, Evaldo Cabral de. Rubro Veio: o imaginário da Restauração Pernanbucana. Rio de Janeiro: Nova Fronteira, 1986. p. 126.

${ }^{86}$ SCHWARTZ, Stuart B. "Prata, açúcar e escravos: de como o império restaurou Portugal". In: Revista Tempo, vol. 12, n. 24, 2008. p. 212. Este mesmo autor informa que, por volta de 1630, havia 350 engenhos produzindo mais de vinte mil toneladas de açúcar por ano.

${ }^{87}$ A ocupação holandesa no Brasil se deu entre os anos de 1630 e 1654 . E Angola esteve sob domínio batavo entre 1641 e 1648. 
estabelecido governo português efetuou mudanças no seu modo de governar, tanto em relação à metrópole como às suas colônias, com destaque para a crescente importância do Atlântico Sul.

Algumas medidas foram tomadas visando a melhora da situação administrativa do Império, o que denota um interesse em organizar a estrutura de exploração que viabilizasse rendimentos mais significativos capazes de sustentar a independência de Portugal. Percebese que, neste momento, as ações governativas passam a agir num sentido metodicamente orientado, buscando sempre uma maior racionalização e padronização do mundo ultramarino. Institui-se o Conselho Ultramarino (1642), delineia-se a Repartição Sul (1643), cria-se o Principado do Brasil (1645), organiza-se a Companhia de Comércio do Brasil (1649) e reconhece-se o direito de representação do Brasil nas Cortes portuguesas (1653). ${ }^{88}$ Enfim, “em grande medida, buscava-se aproximar o Brasil, de forma mais íntima, de seu soberano recém-restaurado." 89

Tendo sempre a preocupação de se sustentar economicamente, a Coroa portuguesa, apesar da aplicação de tais medidas acima mencionadas, não se viu livre dos problemas que a colocavam numa situação nada cômoda. Era necessária, urgentemente, a injeção maciça de recursos. Então, foi durante este quadro crítico que surgiram homens que pensaram o Império português sob novo molde, alicerçado em base racional e burocrático, tendo como norte a exploração colonial, já que Portugal era, definitivamente, um reino que se fez via comércio-marítimo. Assim, percebe-se que a ânsia por recursos econômicos fez com que houvesse o reconhecimento da necessidade de reformulação nos padrões de relacionamento entre a Coroa e seus vassalos e entre Metrópole e Colônias. O caso dos bandeirantes paulistas é emblemático e, por isso, tema principal a ser discutido, porém antes seria interessante fazer uma ressalva e atentar-se para as discussões em torno dos judeus e cristãos-novos trazidas pelo padre Antonio Vieira.

\footnotetext{
${ }^{88}$ Para maiores informações ver GOUVÊA, Maria de Fátima Silva. "Poder Político e Administração na Formação do Complexo Atlântico Português (1645-1808).” In: FRAGOSO, João; BICALHO, Maria Fernanda Baptista; GOUVÊA, Maria de Fátima Silva (org.). O Antigo Regime nos Trópicos: a dinâmica imperial portuguesa (séculos XVI-XVIII). Rio de Janeiro: Civilização Brasileira, 2001. ${ }^{89}$ Idem, Ibidem. p. 294. Laura de Mello e Souza também mostra como o Brasil foi se tornando cada vez mais importante para Portugal. Para ela "a frágil situação do Reino no período imediato à Restauração de 1640 alimentava, assim, a idéia de estabelecer no Brasil um vasto império." SOUZA, Laura de Mello e. O Sol e a Sombra: política e administração na América portuguesa do século XVIII. São Paulo: Companhia das Letras, 2006. p. 100.
} 
Os judeus e cristãos-novos, que por muitíssimo tempo foram considerados impuros, de sangue infecto e indesejáveis numa sociedade cristã, detinham grande parte da preocupação daquele que é tido como "a mais brilhante expressão do século XVII em mundo lusitano"90, o padre Antonio Vieira. Alguns de seus textos são muito claros quanto a sua intencionalidade no uso dos judeus e cristãos-novos para os planos de re-estruturação do Império português. Como sabido, este padre jesuíta teve intensa participação no movimento de Restauração bragantina, exercendo funções como diplomata e, até mesmo, o de conselheiro Real de D. João IV. ${ }^{91}$ E é justamente nos conselhos, ou melhor, nas propostas com relação aos judeus e cristãos-novos que se percebe o tom das mudanças.

Atento à realidade econômica mundial e às transformações ocorridas durante os meados do século XVII, principalmente com relação à péssima situação em que se encontrava Portugal e suas possessões, Antonio Vieira é muito específico em suas palavras. Diz ele ao Rei: "Senhor, Portugal não se pode conservar sem muito dinheiro, e para o haver, não há meio mais eficaz que o do comércio, e para o comércio não há outros homens de igual cabedal e indústria aos de nação." ${ }^{92}$ Dois pontos nessa fala são fundamentais: 1) a percepção de que a riqueza está nas mãos daqueles que manipulam o comércio; 2) o reconhecimento dos homens de "nação" como detentores da grande parte dessa atividade.

Vieira foi muito enérgico quanto a sua proposta. Para ele a solução econômica de Portugal estava na aceitação dessa gente de nação e de seu capital muito costumeiramente investido nas transações comerciais ultramarinas. Atualmente tem-se em mente que "talvez dois terços da comunidade mercantil de então fosse composta por cristãos-novos" "93, e estes, em sua maioria, recebiam restrições de todos os aspectos em solo luso, o que os forçaram a se estabelecer em outros lugares, em especial naqueles onde não haviam barreiras quanto ao culto religioso, por exemplo, os Países Baixos.

Em tom de desabafo, diz Vieira:

verdadeiramente é dificultosíssima de entender a razão de estado de Portugal, porque, sendo um reino fundado todo no comércio, lança os

\footnotetext{
${ }^{90}$ SOUZA, Laura de Mello e; BICALHO, Maria Fernanda. 1680-1720: o império deste mundo. São Paulo: Companhia das Letras, 2000. p. 8.

${ }^{91}$ Para informações mais detalhadas da vida de Antonio Vieira, ver: AZEVEDO, João Lúcio. História de Antonio Vieira. 2a . ed. Lisboa: Livraria Clássica Editora, 1931. Tomo I e II.

${ }^{92}$ VIEIRA, Pe. Antônio. Op. cit. p. 14.

${ }^{93}$ SCHWARTZ, Stuart B. "Prata, açúcar e escravos: de como o império restaurou Portugal". In: Revista Tempo, vol. 12, n. 24, 2008. p. 207.
} 
seus mercadores para os reinos estranhos, e aos estranhos os admite dentro de si mesmo, para que o interesse da negociação e comércio venha a ser todo dos estranhos, e nada seu. É evidente este argumento; porque o que os mercadores portugueses ganham nos reinos estranhos, lá fica, e o que os estranhos ganham no nosso, para lá vai. ${ }^{94}$

Se, num momento, "a Coroa portuguesa se beneficiou financeiramente da guerra social entre a Inquisição e os cristãos-novos e forçou empréstimos e contribuições 'voluntárias' em troca do chamado 'perdão geral",95, isso não significava que a arrecadação fosse certa e muito menos suficiente num momento de crise, além do que a falta de segurança vivida pelos judeus e cristãos-novos era motivo para ocasionar sua fuga, como realmente houve em grande quantidade para a Itália, França e Holanda. Nesse sentido, a pressão gerada pela Inquisição mais prejudicava do que ajudava, na opinião de Antonio Vieira. Em outra proposta redigida a D. João IV, o jesuíta não questionou a existência do Tribunal, ao contrário, a introdução dele foi "uma das mais assinaladas mercês que a misericórdia divina se serviu fazer a este Reino." 96 A implicância de Vieira era com relação aos estilos com que o Santo Ofício procedia quanto a maneira das inquirições e julgamentos, ocasionando muitos males a Portugal. Foi enumerando alguns “inconvenientes" que o padre chega à conclusão de que o medo e a insegurança gerados com a opressão inquisitorial eram as causas principais da fuga dos judeus e cristãos-novos de Portugal, e com eles iam também o capital e as atividades comerciais capazes de sustentar o reino. Enfraquecia-se Portugal com a evasão deles e fortaleciam-se os inimigos que os acolhiam.

Seja no plano espiritual, seja no plano material, o que se vê nas palavras de Antonio Vieira é a necessidade conjuntural de aceitação e de flexibilização do tratamento em relação aos de "sangue impuro". De indesejáveis no meio social, os judeus e cristãos-novos passaram a ser úteis, em sua ótica, para a restauração do Reino português e, principalmente, aos planos para o seu idealizado Quinto Império. ${ }^{97}$ Mas este caso não é o único que ilustra

\footnotetext{
${ }^{94}$ VIEIRA, Pe. Antônio. Op. cit. p. 20.

${ }^{95}$ SCHWARTZ, Stuart B. Op. cit. p. 207.

${ }^{96}$ VIEIRA, Pe. Antônio. "Proposta que se fez ao Sereníssimo Rei D. João IV a favor da Gente de Nação”. Obras Escolhidas, vol. IV, Lisboa: Sá da Costa, s/d. p. 27.

${ }^{97}$ Resumidamente seria o Quinto Império "um reino de mil anos, compreendendo todas as raças e culturas, unidas fraternalmente a fé católica e sob a égide de um só império mundial, governado pelos dois vigários de Cristo: o papa, em Roma, chefe do plano espiritual; e o rei, em Portugal,
} 
as mudanças no padrão de relacionando entre Coroa e vassalos pós-1640. O exemplo dos paulistas e de suas atividades sertanistas é bem elucidativo.

O período entre as décadas de 1660 e 1680 marcaram Portugal com o momento agudo da crise econômica, vivida há tempos. Charles Boxer coloca que vigoravam em terras lusas as discussões sobre o preço do açúcar, do tabaco e do escravo africano, além do temido déficit na balança comercial. No entanto, apresentavam-se também alternativas que poderiam viabilizar a recuperação da sua economia. Podem ser enumerados três tópicos de destaque: 1) a criação de manufaturas em Lisboa; 2) a abertura de novos ramos de comércio - pensa-se aqui na prata do Peru; e 3) o descobrimento e a exploração de metais preciosos no Brasil. Não só Boxer, outros historiadores também defendem a opinião de que a terceira opção era mais viável no momento. ${ }^{98}$

Portanto, “em meados do século XVII, a existência dessas minas [as de São Paulo] importava mais como prova de presença de ouro no Brasil do que pela sua produção”, isto é, os indícios de riqueza instigaram as autoridades portuguesas a investir na sua procura, e, "por essa época já era conhecida na Corte de Lisboa a capacidade dos paulistas de embrenharem-se pelos sertões." "99 São Paulo e seus sertanistas tornam-se, agora, parte efetiva dos planos de Portugal, visto que "o governo passou a estimular mais ativamente as buscas de minas de prata, ouro e esmeraldas no Brasil, buscas que tinham sido feitas, intermitentemente, desde meados do século XVI, pela Coroa." ${ }^{100}$ A forma como se deu essa aproximação na relação entre metrópole e sertanistas na condição de Coroa e vassalos dentro de um jogo de interesses será analisada a seguir.

chefe do plano temporal." Cf. SOUZA, Laura de Mello e; BICALHO, Maria Fernanda. Op. cit. p. 10. Percebe-se que o império a que se referia Vieira tem sua materialização nas conquistas lusitanas espalhadas pelo mundo, e as suas propostas para revitalizá-lo denotavam uma objetividade não simplesmente mundana, mas também espiritual, como a conversão e a expansão da fé católica. Confundiam-se os planos material e espiritual.

${ }^{98}$ Cf. BOXER, Charles R. Salvador de Sá e a luta pelo Brasil e Angola (1602-1686). São Paulo: Editora Nacional; Editora da USP, 1973. Para Luíza Volpato, em meio à crise econômica “(...) a política colonial portuguesa via na descoberta de metais preciosos no Brasil a alternativa mais viável para a economia portuguesa." VOLPATO, Luíza. Entradas e Bandeiras. São Paulo: Global, 1985. p. 90. Virgílio Noya Pinto também discorre sobre as alternativas de Portugal e a atenção dada à procura de metais preciosos no Brasil. Cf. PINTO, Virgílio Noya. Op. cit.

${ }^{99}$ VOLPATO, Luiza Rios Ricci. Op. cit. p. 90.

100 BOXER, Charles R. A Idade de Ouro do Brasil: dores de crescimento de uma sociedade colonial. $3^{\text {a }}$. ed. Rio de Janeiro: Nova Fronteira, 2000. p. 50. 


\subsection{A Política de Incentivos: prestação de serviços e recompensas}

Durante muito tempo, já desde o início da colonização da América, a Coroa portuguesa esteve próxima das atividades de prospecção aqui efetuadas. É certo que houve variações no modo como esta participação se deu, ora mais direta ora mais omissa, porém esteve sempre sequiosa por notícias que confirmassem a existências das riquezas minerais. Não foram poucas as instruções destinadas às autoridades governamentais presentes na colônia, referentes às formas e atitudes que se deviam levar, considerando-se o desejo do melhor aproveitamento possível em termos de exploração.

Existem cartas oficiais, alvarás e relatórios que testemunham a preocupação Real em avançar no conhecimento das potencialidades minerais do Brasil. Muitos homens, ourives e práticos em mineração, foram enviados para averiguação de minas e metais encontrados. Na maioria dos casos, estas diligências resultavam em relatórios com pareceres dos especialistas no que diz respeito a veracidade das minas e as conveniências mais adequadas a serem tomadas. ${ }^{101}$ Esta documentação mostra que, apesar da variação na sua intensidade ao longo dos anos, as autoridades reais estiveram sempre atentas aos acontecimentos que envolviam as pesquisas e a exploração de minas.

Como visto anteriormente, a Restauração portuguesa, ocorrida em 1640, gerou a necessidade de mudanças, dentre elas o aumento da atenção destinada à pesquisa mineral. Logo, neste contexto, "estorcia-se pois o Brasil premido pela terrível crise econômicofinanceira e as altas autoridades do Estado lançaram-se ardorosamente na via das pesquisas mineradoras", como informa Afonso Taunay. E mais, "era preciso, por força, descobrir metais nobres, ou de vez, convencer-se de que o Brasil era terra onde existia a fertilidade das minas." $" 102$

${ }^{101}$ Como exemplo Cf. "Nota do Alvará Régio concedendo ordenado a Luis Martins, mandado a examinar as minas de metais, que se constava existirem nas terras do Brasil, de 7 de setembro de 1559.” In: Documentos Interessantes para a História e Costume de São Paulo. Vol. XLVIII. Publicação Oficial: Arquivo do Estado de São Paulo; São Paulo: Estabelecimento Gráfico Irmãos Ferraz, 1929. p. 31-32; "Correspondência de Diogo Botelho - Governador do Estado do Brasil (1602-1608)." In: R.I.H.G.B. Vol. LXXIII. Rio de Janeiro: Typographia Universal de Laemmert, 1910. p. 6; "Sobre as Minas de São Vicente do Brasil." In: R.I.H.G.S.P. Vol. XLIV. São Paulo: Typographia do Diário Oficial, 1948. p. 316-318.

102 TAUNAY, Afonso de E. História Geral das Bandeiras Paulistas. Vol. 9. São Paulo: Museu Paulista - Imprensa Oficial do Estado, 1948. p. 63. 
Não obstante as muitas e dificultosas expedições feitas ao longo das décadas, o sertão ainda era um território pouco conhecido, menos ainda a sua disponibilidade no que diz respeito aos recursos naturais. ${ }^{103}$ Apenas as informações oriundas de São Paulo chegavam a animar, seja porque aí se encontrava uma incipiente exploração mineral, seja porque aí se encontravam pessoas com grande habilidade sertanista, capazes de vencer os embaraços do mundo interior. De fato, "com o correr do tempo, os paulistas tornaram-se tão habilidosos nas artes do sertão e dos matagais quanto os ameríndios já o eram, ou mesmo, segundo alguns contemporâneos, "como as próprias feras'."104 A própria Coroa estava ciente disso, e sabia que "a verdade estava em que, sem os de São Paulo, não se poderiam aproveitar devidamente aqueles sertões."

Incentivar, esta era a ordem expedida constantemente. Sem recursos suficientes para coordenar as ações de procura e exploração de metais e pedras preciosas, a Coroa passou a depender da iniciativa privada para tal, daí a enxurrada de cartas destinadas às autoridades do governo colonial e aos paulistas contendo palavras de incentivo à pesquisa de prospecção, lembrando sempre que tudo seria visto pelo Rei como digno de uma exemplar vassalagem. Enfim, “D. Pedro II, depois de ver frustadas ou mal correspondidas todas as esperanças concentradas nas minas, resolveu dar um grande passo: dirigiu as mais lisonjeiras cartas à gente principal de São Paulo, confiando-lhe por assim dizer a questão."106

Sem sombra de dúvida, sabe-se que "a Corte despachava cartas régias e mais cartas régias, ou instuções secretas, estimulando os colonos a se adentrarem pelo sertão à procura do cobiçado metal"107, mas além disso, é preciso lembrar que no cerne desta política de incentivos havia a contrapartida da oferta de títulos, honras e mercês como chamariz para aqueles que desejavam a ascensão social, isto é,

um dos principais estímulos para a marcha para o sertão era a esperança, sempre presente, de encontrar metais e pedras preciosas. (...) A descoberta de minas no Brasil era insistentemente incentivada pela

\footnotetext{
${ }^{103}$ Sertão aqui, como dizia os europeus, denotava um território promissor, na fronteira do mito e da experiência. Cf. KOK, Glória Porto. O Sertão Itinerante: expedições da capitania de São Paulo no século XVIII. São Paulo: Hucitec: Fapesp, 2004.

${ }^{104}$ BOXER, Charles R. Op. cit. p. 58.

${ }^{105}$ HOLANDA, Sérgio Buarque de. "Metais e Pedras Preciosas". In: História Geral da Civilização Brasileira: a época colonial. Rio de Janeiro: Bertrand, Tomo I, Volume II, 1989. p. 272.

${ }^{106}$ ABREU, Capistrano. Op. cit. p. 162.

${ }^{107}$ MOOG, Clodomir Vianna. Op. cit. p. 91.
} 
politica colonial portuguesa. Prêmios, honras e mercês eram oferecidos àqueles que se dispusessem a enfrentar os riscos e conseguissem atingir o tão almejado objetivo. ${ }^{108}$

Na verdade, esta política desempenhada com maior intensidade por Portugal nas últimas décadas do século XVII não era nenhuma novidade. Dela sempre se utilizaram os monarcas lusitanos, principalmente após as descobertas marítimas. ${ }^{109}$ Veja-se que,

no processo de colonização do Brasil, a Coroa utilizou-se da iniciativa particular e nela se apoiou, buscando, porém, sempre seu controle. Se, na perspectiva do Estado contemporâneo, essa situação pode ser vista como fragilidade, à época, no processo de formação do Estado, tal política constituiu hábil recurso: a Coroa utilizava recursos humanos $e$ financeiros particulares para viabilizar seus projetos, sem que the coubesse nenhum ônus, cedendo, em troca desse apoio, terras, cargos, rendas e títulos nobiliárquicos. ${ }^{110}$

O sucesso deste tipo de política só foi possível porque houve a junção de dois importantes fatores: primeiro, a constituição de Portugal como um Estado patrimonialista; e, segundo, o assentamento da sociedade portuguesa e colonial em valores estamentais.

Analisando-se a tipicidade do Estado português da era Moderna é de comum percepção a perene indissociação entre o Rei e o Estado. Um representava o outro. “O Monarca era o centro simbólico e originário do poder. Sua dominação, de caráter pessoal, caracterizava-se por considerar o estado patrimônio do soberano, como direito privado" "111, salienta Júnia Ferreira Furtado. E ainda, diz a autora, "para se fazer representar e efetivar esta dominação, o Rei dispunha de um quadro administrativo que era extensão de seu próprio poder, como sua prioridade." ${ }^{112}$ Logo, "nessa perspectiva, era de origem pessoal

${ }^{108}$ VOLPATO, Luiza Rios Ricci. Op. cit. p. 37.

${ }^{109}$ Segundo António Vasconcelos de Saldanha, esta prática pode ser observada nas doações das primeiras capitanias hereditárias. Cf. SALDANHA, António Vasconcelos de. As Capitanias do Brasil: antecedentes, desenvolvimento e extinção de um fenómeno atlântico. Lisboa: Comissão Nacional para as Comemorações dos Descobrimentos Portugueses, 2001.

${ }^{110}$ RICUPERO, Rodrigo. A Formação da Elite Colonial: Brasil, c.1530 - c.1630. São Paulo: Alameda, 2009. p. 13. Explica ainda o mesmo autor: "A lógica da troca de serviços por mercês foi utilizada pela Monarquia desde a reconquista no próprio Reino e depois por todas as latitudes e longitudes de seu Império, porém, graças às especificidades de cada local, esta lógica contribuiu para moldar sociedades diferentes." Idem, Ibidem. p. 14.

${ }^{111}$ FURTADO, Júnia Ferreira. Homens de Negócio: a interiorização da metrópole e o comércio das minas setecentistas. 2a ed. São Paulo: Hucitec, 2006. p. 47.

${ }^{112}$ Idem, Ibidem. p. 47. 
todo o poder que se reproduzia pela sociedade, primeiro fator da indistinção entre o público e o privado, tão característica desse período." ${ }^{\prime 13}$

Como um Estado Patrimonial, amparando-se ao conceito caro a Max Weber, vale lembrar o papel central do Rei, "como dispensador ou fonte de todas as graças e mercês" "114, e, por isso mesmo, ter em mente que, dentro da lógica da prestação de serviços e da recompensa, tal prática deve ser observada como uma parte indispensável da própria dinâmica do sistema governativo, não estando, portanto, sujeito apenas a maior ou a menor liberalidade do monarca, tanto que foi imprescindível na conquista e manutenção de seu Império. $^{115}$

No caso da colonização do Brasil, logo cedo se deu esta prática. Procurando utilizar o máximo possível de recursos particulares, a fim de se abster de maiores gastos, a Coroa portuguesa determinou que "àqueles que se dispunham a vir a iniciar o povoamento do Brasil [seriam] conferidos títulos e outras graças, porém, eles deveriam arcar com as despesas que se fizessem necessárias tanto para ocupar a terra, dar início à plantação, como para erigir engenhos ou outros estabelecimentos." ${ }^{\prime 16} \mathrm{O}$ desenvolvimento da colônia interessava tanto a Metrópole quanto ao colono: para a primeira a exploração de suas possessões significava ser valorizada sob padrões mercantilistas; já para o segundo a abertura de novas frentes de exploração denotava o surgimento de possibilidades para o

\footnotetext{
${ }^{113}$ Idem, Ibidem. p. 47-48.

${ }^{114}$ RICUPERO, Rodrigo. "Governo-geral e a Formação da Elite Colonial Baiana no século XVI." In: BICALHO, Maria Fernanda; FERLINI, Vera Lúcia Amaral (orgs.). Modos de Governar: idéias e práticas políticas no Império português (séculos XVI a XIX). São Paulo: Alameda, 2005. p. 129. $\mathrm{O}$ conceito de patrimonialismo de Max Weber pode ser consultado no capítulo "Os tipos de Dominação". Cf. WEBER, Max. Economia e Sociedade: fundamentos da sociologia compreensiva. $4^{a}$. ed. Vol. 1. Brasília: Editora Universidade de Brasília, 2009. p. 148-156.

${ }^{115}$ Compartilha-se aqui das palavras de Rodrigo Ricupero quanto a sua escolha entre os conceitos de "Patrimonialismo", o de "economia das mercês" e o de "economia do dom". Diz ele: "a remuneração dos serviços não pode ser vista apenas como dom ou mercê do monarca, fruto de sua maior ou menor liberalidade. A troca de serviços por mercês foi componente central da política adotada pela monarquia portuguesa, que lhe permitiu não só a constituição do Reino independente na península, mas também a montagem do vasto Império. Nesse sentido, acreditamos que o uso do conceito weberiano de patrimonialismo, aplicado à monarquia portuguesa, permite uma melhor compreensão da realidade em sua totalidade, ao contrário de 'economia das mercês' de Fernanda Olival ou 'economia do dom' de Antonio Manuel Hespanha, que, embora expressem a importância da política de troca de serviços por honras e mercês, tendem a isolá-la dentro do contexto mais geral da monarquia, como uma política, entre outras, adotada de forma independente ou não." Cf. RICUPERO, Rodrigo. A Formação da Elite Colonial: Brasil, c.1530 - c.1630. São Paulo: Alameda, 2009. p. 53.

${ }^{116}$ VOLPATO, Luiza Rios Ricci. Op. cit. p. 26.
} 
enriquecimento e a nobilitação. Dessa maneira, ambos estabeleciam um relacionamento muito próximo, porém, quase sempre, tácito. Enfim, entende Florestan Fernandes que esta associação representa como uma forma de divisão de riscos e de solidariedade político-legal e econômica. Uma coroa pobre, mas ambiciosa em seus empreendimentos, procura apoio nos vassalos, vinculando-os aos seus objetivos e enquadrando-os às malhas das estruturas de poder e à burocracia do Estado patrimonial. ${ }^{117}$

De fato, as relações entre os diferentes lados sempre sofreram mudanças em seu tratamento, ora mais tranquilas, ora mais tensas, porém, guardadas as vicissitudes de cada momento e região, ao fim e ao cabo, todos buscavam o mesmo objetivo que era o desenvolvimento da colonização, o enriquecimento e a nobilitação, ou seja, "a sedimentação de uma ordem senhorial-escravista mercantil e cristã que interessava a ambos."118 Como uma espécie de "empresa em conjunto", termo utilizado por Florestan Fernandes e lembrado por Ilana Blaj, "colono e Metrópole uniam-se e articulavam-se constantemente em torno da exploração colonial, seja via agricultura, seja via busca incessante dos minérios preciosos." 119

A oferta de títulos, honras e mercês como prêmios concedidos aos que prestassem serviços à Coroa só teve efeito porque a sociedade em questão estava constantemente em busca de qualificação, de enobrecimento e cada um destes itens eram carregados com valores simbólicos que conferiam a seu portador uma invejada ascensão social. Mais uma vez é Ilana Blaj quem esclarece:

Independente da camada social à qual pertencia o colono, a busca de qualificação elou da requalificação era uma constante. Qualificação para os pobres do reino, para os pequenos e médios agricultores e comerciantes, para os artesãos e mesmo para os filhos bastardos; requalificação para os degredados e para os filhos segundos de uma nobreza empobrecida. Em síntese: enriquecimento, nobilitação, qualificação/requalificação permeavam o imaginário e os interesses do colono. ${ }^{120}$

${ }^{117}$ FERNANDES, Florestan. Circuito Fechado: quatro ensaios sobre o poder institucional. São Paulo: Hucitec, 1976. p. 34.

${ }^{118}$ BLAJ, Ilana. A Trama das Tensões: o processo de mercantilização de São Paulo colonial (16811721). São Paulo: Humanitas/FFLCH/USP: Fapesp, 2002. p. 220.

119 Idem, Ibidem. p. 302. Cf. também BLAJ, Ilana. "Mentalidade e Sociedade: revisitando a historiografia sobre São Paulo colonial." In: Revista História. São Paulo. n”. 142-143, 2000.

${ }^{120}$ BLAJ, Ilana. "Mentalidade e Sociedade...”. Op. cit. p. 244. 
Portanto, tem-se, de um lado, uma Coroa que lutava para se manter em pé, enfrentando problemas políticos, militares e financeiros, e de outro, uma colônia enorme em termos espaciais e que prometia gerar muita riqueza mas que, para isso, era preciso avançar no seu processo de exploração.

O interesse estava voltado, em especial, para as supostas minas de ouro das quais se tinham notícias. E, em se tratando de entradas sertanistas, era do conhecimento de todos a familiaridade dos paulistas no assunto. Logo, "era fundamental que o Rei colocasse esses vassalos a seu serviço, a fim de que eles utilizassem de seu conhecimento do interior do Brasil e de sua técnica de penetração pelo sertão para descobrir riquezas."121 Para tanto, "o monarca era aconselhado a usar determinadas estratégias: para os paulistas mais valiam honrarias do que riquezas. O Rei era aconselhado a oferecer, em troca das peregrinações, títulos e mercês." ${ }^{22}$ E foi o que aconteceu inúmeras vezes, seja diretamente pelo Rei, seja através de seus representantes. ${ }^{123}$

Em carta destinada ao governador do Rio de Janeiro, datada de 12 de janeiro de 1690, o Rei assim se expressa: visando o descobrimento das minas de ouro e prata "a mais eficaz diligência para se conseguir será ficarem persuadidos os moradores de São Paulo” e, para tanto, era preciso transmitir a eles que "este serviço me será agradável e do bom ânimo e vontade com que estou para fazer honras e mercês que os distinguam e diferenciam entre os outros naturais." Por fim, ordena que "por bem e vos dou poder para que todos aqueles que vos parecerem capazes e se quiserem empregar no descobrimento das minas de ouro e prata, que possais prometer-lhe o foro de fidalgos da minha casa e de cavaleiros fidalgos dela e dos hábitos das três ordens militares", mas ressalva que tudo isso só será efetivada após um exame nas minas declaradas quanto a sua qualidade e rentabilidade. ${ }^{124}$ Estas mesmas informações e ordens foram confirmadas em outras cartas com datas de 14 e 16 de

\footnotetext{
${ }^{121}$ VOLPATO, Luiza Rios Ricci. Op. cit. p. 91.

${ }^{122}$ Idem, Ibidem. p. 91.

${ }^{123}$ Vale lembrar que no Brasil, "o governador-geral, como representante do rei, também cumpria esse papel [o de dispensador de graças e mercês], mesmo que em menor escala e sempre sujeito à confirmação ou não do monarca." RICUPERO, Rodrigo. "Governo-geral e a Formação da Elite Colonial Baiana no século XVI." Op. cit. p. 129.

124 "Carta Régia dando poder ao governador do Rio de Janeiro para conceder honras e mercês aos moradores de São Paulo e mais capitanias que se empregassem no descobrimento de ouro e prata 13 de janeiro de 1690." In: R.I.H.G.S.P. Vol. XVIII. São Paulo: Typographia do Diário Oficial, 1914. p. 263-264.
} 
janeiro de 1693. Numa delas, o Rei concede ao governador do Rio de Janeiro, Antonio Paes de Sande, a "faculdade para que em meu nome possais propor, e dar todas as honras e mercês que expedidas pela Secretaria de Estado se vos declara deveis prometer aos Paulistas." 125

A política de concessão de prêmios era tanta que o governador do Rio de Janeiro, Artur de Sá e Menezes, precisou perguntar ao Rei, em 28 de maio de 1698, "quais as mercês que podiam ser concedidas aos descobridores de minas de cobre, estanho, salitre e calaim." "126 Talvez acostumado com toda esta prática, o mesmo governador chegou a exagerar em suas promessas. No ano de 1701, o rei ficou sabendo que ele prometeu que "os serviços dos descobridores de ribeiros auríferos teriam prêmios como os prestadores em guerra viva." Esta atitude desagradou ao monarca, pois "pareceu-me estranhar-vos mui severamente excederes o vosso Regimento" e, por isso mesmo, “obrastes muito mal neste particular." 127

Enfim, essa relação entre Coroa e vassalo era sustentada por uma espécie de contrato. Numa extremidade ficavam os títulos, honras e mercês monopolizadas pelo Rei, noutra ponta havia o colono disposto a assumir riscos de todas as naturezas a fim de alcançar os prêmios ofertados. Tal noção contratualista, isto é, a constituição de uma vassalagem contratual onde os serviços prestados ao rei eram postos em prática apenas mediante recompensas, era algo que fazia parte da cultura política dos paulistas e que, além de ter ajudado a criar a imagem de uma "República" de São Paulo, causava espanto nos contemporâneos, como bem analisou Adriana Romeiro. ${ }^{128}$ Dessa maneira,

\footnotetext{
125 “Carta Régia dando poder ao governador do Rio de Janeiro para conceder honras e mercês aos moradores de São Paulo e mais capitanias que se empregassem no descobrimento de ouro e prata 16 de janeiro de 1690." In: Idem. p. 293-294. Cf. também "Carta Régia concedendo amplíssima jurisdição ao Governador do Rio de Janeiro para os descobrimentos de minas de ouro e prata em Paranaguá, Itabaiana e Serra de Sabarabuçu - 14 de janeiro de 1693." In: Documentos Interessantes para a História e Costume de São Paulo. Vol. XLVII. São Paulo: Casa Vanorden, 1929. p. 34-35.

126 “Carta de Artur de Sá e Menezes ao Rei perguntando quais as mercês que podiam ser concedidas aos descobridores de minas de cobre, estanho, salitre e calaim - de 28 de maio de 1698." In: R.I.H.G.S.P. Vol. XVIII. São Paulo: Typographia do Diário Oficial, 1914. p. 348.

127 “Carta Régia a Artur de Sá e Menezes estranhando mui severamente e desaprovando o ato deste pelo qual os serviços dos descobridores de ribeiros auríferos teriam prêmios como os prestados em guerra viva - de 19 de novembro de 1701." In: Documentos Interessantes para a História e Costume de São Paulo. Vol. LI. São Paulo: Estabelecimento Gráfico Irmãos Ferraz, 1930. p. 46.

${ }^{128}$ Cf. ROMEIRO, Adriana. Paulistas e Emboabas no Coração das Minas: idéias, práticas e imaginário político no século XVIII. Belo Horizonte: Editora UFMG, 2008.
} 
havia o consenso de que, avessos às autoridades coloniais, os paulistas somente se punham a serviço da Coroa, quando devidamente recompensados, depois de árduas e arrastadas negociações, nas quais não hesitavam em exigir um sem-número de mercês e honrarias. Para convencê-los a se engajarem no serviço real, governadores e vice-reis eram obrigados a lançar mão de prêmios elevados, sem os quais eles se mostravam indiferentes aos apelos da Coroa. ${ }^{129}$

Os acordos estabelecidos entre a Coroa e os paulistas ocorriam com grande frequência, "ora articulando-se aos planos da Coroa em intensificar a busca de metais preciosos, ora oferecendo serviços militares em defesa do patrimônio açucareiro e pecuário do Nordeste." ${ }^{\prime 30}$ Muitos sertanistas de São Paulo foram convocados para compor as campanhas de "desinfecção" contra índios e negros revoltosos, com destaque para os conflitos no sertão da Bahia. ${ }^{131}$ Lembra John Monteiro que os paulistas foram também convidados para fazer parte do conflito luso-holandês em fins da década de 1640. Dentre todas as ocasiões, a campanha de Domingos Jorge Velho pode ser considerada a mais famosa por ter sido a responsável pela destruição do quilombo dos Palmares. ${ }^{132}$ Seja em campanhas militares, seja em projetos de desbravamento, ou em procura de minas, os paulistas eram sempre úteis à Coroa, isto é, "acenando com sedutoras promessas de títulos honoríficos, terras e até dinheiro, os paulistas eram mobilizados para servir, por determinados períodos, de mercenários." "133

Sem dúvida, "por quase dois séculos, um dos mais importantes itens do rol dos serviços pretados à Coroa pelos paulistas foram os feitos como descobridores de metais preciosos."134 Durante todo esse período houve muitas entradas sertanistas que se divergiam entre si, tanto com relação aos objetivos traçados (caça de índios ou pesquisa mineral), quanto a forma de sua organização (oficial ou privada). O certo, porém, é que todas fizeram parte do processo de desbravamento e exploração do interior do Brasil, o que

\footnotetext{
${ }^{129}$ Idem, Ibidem. p. 237-238.

${ }^{130}$ MONTEIRO, John M. Op. cit. p. 92.

${ }^{131}$ Sobre a chamada Guerra dos Bárbaros Cf. PUNTONI, Pedro. A Guerra dos Bárbaros: povos indígenas e a colonização do sertão nordeste do Brasil, 1650-1720. São Paulo: Hucitec, 2000.

${ }^{132}$ Os paulistas colocaram como condição para aceitar a tarefa o direito sobre parte dos negros revoltosos, além de sesmarias na própria região e exigiram ainda que o governo arcasse com os gastos da empresa (pólvora e chumbo). Cf. "Condições ajustadas com o governador dos paulistas Domingos Jorge Velho em 14 de agosto de 1693 para conquistar e destruir os negros de Palmares." In: R.I.H.G.B. Vol. XLVII. Rio de Janeiro: Typographia Universal de Laemmert, 1884. p. 19 e segs. ${ }^{133}$ Idem, Ibidem. p. 92 e segs.

${ }^{134}$ ROMEIRO, Adriana. Op. cit. p. 110.
} 
interessava diretamente a Coroa portuguesa. O incentivo via promessas servia, então, como mola propulsora que ajudava a acelerar este processo.

Embora as promessas de mercês tenham sido feitas em muitas ocasiões, elas eram destinadas a colonos específicos, ou seja, "aos principais integrantes das expedições do sertão, incentivadas pelo governo, prometia-se a concessão de títulos." ${ }^{\text {"135 }}$ Isto se dava por dois motivos: primeiro porque a Coroa procurava sempre se relacionar com a elite local estabelecida, já que esta era a responsável direta pela manuntenção da ordem em termos de administração do poder na área, e muitos dos membros desta elite local estavam envolvidos com o bandeirismo; e segundo porque somente pessoas com cabedal financeiro disponível eram capazes de prestar tais serviços.

Além deste afunilamento no alcance social que as promessas abarcavam, outro fator que também deve ser considerado é a dificuldade em se conseguir o prêmio prometido. Se já não bastassem as agruras presentes nas jornadas sertanistas e o quase inalcançável sucesso nas pesquisas de prospecção, a obtenção da mercê era outra tarefa demasiadamente custosa, demorada e cansativa. Enfim, "servir a Coroa era apenas o primeiro passo para se obter as tão almejadas honras e mercês. O segundo, não necessariamente mais simples, era requerê-las junto ao monarca ou aos seus representantes." ${ }^{\text {"136 }} \mathrm{E}$, levando-se em consideração tudo isso, "é evidente que nem sempre as promessas eram mantidas: a distância e o acesso à corte, a falta de contatos influentes, a troca do soberano poderiam significar a perda das recompensas prometidas." ${ }^{137}$ Portanto, uma coisa era a promessa, outra era a mercê efetiva.

A descoberta oficial de minas de ouro feita nos primeiros anos da década de 1690 acarretou, inevitavelmente, na abertura de novas frentes de exploração, surgindo muitos outros pontos de mineração. Apesar de muitos bandeirantes terem encontrado o tão esperado ouro, pouco receberam em troca. Ressalta Adriana Romeiro que,

de modo geral, a Coroa recusou-se a atender as reivindicações dos descobridores, sobretudo os pedidos de concessão de foros de fidalgo e cavaleiro da Ordem de Cristo, alegando pretextos pouco objetivos. Um deles foi o de que as minas não eram de rendimento duradouro, sendo que as promessas régias de comendas das ordens militares limitavam-se as minas certas e ricas. Outra alegação era de que as reivindicações dos paulistas incorriam na 'falta de notório merecimento em razão das muitas

${ }^{135}$ KOK, Glória Porto. Op. cit. p. 68.

${ }^{136}$ RICUPERO, Rodrigo. A Formação da Elite Colonial: Brasil, c.1530 - c.1630. São Paulo: Alameda, 2009. p. 72.

${ }^{137}$ Idem, Ibidem. p. 21. 
ações consideradas ilícitas e da conduta pouco virtuosa', como a escravização injusta de índios, a prática de crimes e os abusos cometidos contra governadores. A suspeita de sangue infecto, de cristão novo ou gentio da terra, que recaía sobre grande parte dos paulistas, também constituiu um obstáculo na Mesa de Consciência e Ordens, encarregada de proceder às provanças dos candidatos. ${ }^{138}$

Por outro lado, "a Coroa revelou-se mais pródiga na concessão de patentes de oficiais milicianos" ${ }^{\prime 139}$. A posse de patentes militares e de cargos político-administrativos por parte dos paulistas representou, até certo ponto, o reconhecimento de seus esforços, o que dava a eles o controle inicial da exploração da nova área da colônia. De fato, além do direito sobre as minas - sempre com a condição do pagamento do quinto - muitos sertanistas foram nomeados para as funções militares e políticas, visando-se com isso, na ótica da Coroa, manter a ordem do local e, de certa maneira, compensar seus esforços colocando-os no controle.

Todavia, esta situação iria durar pouco. A descoberta das minas gerou uma forte onda de migração oriunda de todas as partes do Brasil e de fora dele, e isso fez com que os paulistas - pioneiros neste processo - se sentissem ofendidos e lesados com a concorrência de outras pessoas estranhas a seu grupo na exploração das minas. O descontentamento dos paulistas estava baseado na possível quebra do "direito de conquista" adquirido por eles uma vez que se julgavam os únicos responsáveis pela descoberta das minas. Enfim,

os paulistas vão exigir o direito à posse das minas de ouro, alegando que, na carta régia de 18 de fevereiro de 1694, o rei D. Pedro II prometia aos descobridores delas, para além do foro de fidalgo e o hábito de qualquer das suas três ordens militares, 'as propriedades das minas, obrigadas apenas ao pagamento do quinto para a real fazenda' ${ }^{140}$

Em ata da Câmara da vila de São Paulo, datada de 16 de abril de 1700, foi exigida do governador uma representação junto ao rei alegando

que as terras do território das minas de Cataguases, assim campos como matos lavradios, de direito pertenciam aos paulistas, para as possuírem por datas de S. M. ou do donatário, porquanto eles foram os que conquistaram e descobriram as minas de ouro que de presente se lavram, o que é notório e patente, o que tudo fizeram à custa de suas vidas e

\footnotetext{
${ }^{138}$ ROMEIRO, Adriana. Op. cit. 250-251.

${ }^{139}$ Idem, Ibidem. p. 251.

${ }^{140}$ ROMEIRO, Adriana. "Revisitando a Guerra dos Emboabas: práticas políticas e imaginário nas Minas setecentistas.” In: BICALHO, Maria Fernanda; FERLINI, Vera Lúcia Amaral. (orgs). Modos de Governar: idéias e práticas políticas no Império português (séculos XVI a XIX). São Paulo: Alameda, 2005. p. 397.
} 
fazendas, sem dispêndio algum da fazenda real, e que seria grande injustiça, concederem as ditas terras aos moradores do Rio de Janeiro, que nunca tiveram parte tanto na conquista, como descobrimento. ${ }^{141}$

Apesar de todos os apelos elaborados defendendo a garantia do monopólio paulista na exploração mineira, nada podia ser feito para evitar a quebra desta situação. A aglomeração de colonos em torno das minas era fato natural, e de igual maneira eram os conflitos que disso viriam. De fato, o choque entre paulistas e outros colonos, sustentado em grande medida pela incompatibilidade político-cultural, atingiu a sua forma mais extrema: o conflito armado. ${ }^{142}$ A chamada "guerra dos emboabas", ocorrida entre os anos de 1708 e 1709, representou o fim da hegemonia paulista nas Minas Gerais, não apenas em termos de poder local ou de controle na exploração das minas ${ }^{143}$, mas também em termos de administração visto que a Coroa se aproveitou da instabilidade gerada com o conflito para tomar as "rédeas" da nova e próspera área da colônia. "Ao fim e ao cabo, o levante emboaba era uma feliz coincidência aos propósitos da Monarquia."144

Os paulistas que, anteriormente, foram úteis para a consolidação dos planos da Coroa em ampliar a exploração do Brasil, especificamente em relação à mineração passam agora a ser um empecilho para o próprio desenvolvimento da minas pois causavam transtornos na nascente sociedade mineira devido às suas tentativas de se manter no controle econômico, militar e político, coisa que seria impossível sustentar por mais tempo. Maria Verônica Campos buscou perceber uma característica encontrada nos conflitos até então pouco valorizada e que pode ser vista na ocasião da guerra dos emboabas. Para ela

na conjuntura de expansão da fronteira, os motins são mais um sinal de fraqueza que de força das elites locais. Destituídas paulatinamente das funções que desempenhavam durante a abertura e devassamento de novas

${ }^{141}$ Atas da Câmara da Vila de São Paulo, v.VII, p.536. In: Aureliano Leite. O cabo-maior dos paulistas na guerra com os emboabas. São Paulo, Livraria Martins, 1942. p. 37. Apud. ROMEIRO, Adriana. Op. cit. p. 397.

142 "Em vez de uma mera disputa por terras e riquezas, a Guerra dos Emboabas foi, sobretudo, um conflito entre práticas e concepções políticas de paulistas e forasteiros, as quais, provenientes de experiências históricas diferentes, desembocariam em fins do século XVII no cenário explosivo das Minas.” ROMEIRO, Adriana. Paulistas e Emboabas no Coração das Minas: idéias, práticas e imaginário político no século XVIII. Belo Horizonte: Editora UFMG, 2008. p. 30.

${ }^{143}$ Cf. "Carta de Antonio de Albuquerque Coelho de Carvalho a D. João V sobre o requerimento da Câmara de S. Paulo para que fossem restituídas aos paulistas as terras das minas de que haviam sido expulsos pelos Emboabas, de 26 de abril de 1712." In: Documentos Interessantes para a História e Costume de São Paulo. Vol. XLVII. São Paulo: Casa Vanorden, 1929. p. 80-81-82.

${ }^{144}$ Idem, Ibidem. p. 318. 
áreas de colonização, reagiam no momento em que a Coroa não as recompensava com as mercês e funções prometidas com levantes, ameaças, redação de termos de reivindicações e eleição de autoridades. $^{145}$

Enfim, os paulistas estavam perdendo espaço nas Minas Gerais e a Coroa estendia até aí a sua política centralizadora levada à cabo nos anos iniciais do século XVIII. Se já não bastasse a retirada de grande parte dos paulistas do controle das Minas, também “a capitania de São Paulo foi gradativamente sendo ofuscada", até que, "em 1720 separou-se de Minas Gerais." ${ }^{146}$ Nesse instante, os paulistas voltam suas atenções para outra região da colônia: as recém-descobertas minas de Cuiabá e Mato Grosso.

Portanto, como se viu ao longo deste capítulo, os paulistas foram extremamente úteis à Metrópole. Devido à especialização nos assuntos ligados ao sertão, foram constantemente procurados pelas autoridades reais que, oferecendo títulos, honras e mercês, visavam estabelecer um contrato de prestação de serviços em torno da descoberta de minas de metais e pedras preciosas. É preciso ter em mente que esta relação entre São Paulo e Portugal, ou melhor, entre os bandeirantes paulistas e a Coroa portuguesa fez parte do processo que culminou no achamento das minas de ouro ocorrido na década de 1690. Não é possível precisar a intensidade desta influência visto que as empresas sertanistas que desbravaram o interior do Brasil eram formadas por fatores internos e externos, ou seja, tal processo histórico não pode ser creditado apenas a um ou a outro fator, foi uma mescla de necessidades, de sobrevivência e de exploração. Vale lembrar também que, dentro deste conjunto todo, não foram somente os bandeirantes da vila de São Paulo os que tiveram parte ativa, habitantes de outras vilas também se envolveram. Assim, é necessário que se dê atenção para uma destas vilas que, na historiografia brasileira, tem vivido injustamente à sombra de São Paulo. Refere-se, aqui, a Taubaté, importante vila que esteve diretamente ligada à história do bandeirismo paulista.

145 CAMPOS, Maria Verônica. "Goiás na década de 1730: pioneiros, elites locais, motins e fronteira.” In: BICALHO, Maria Fernanda; FERLINI, Vera Lúcia Amaral. (orgs). Op. cit. p. 354.

${ }^{146}$ KOK, Glória Porto. Op. cit. p. 51. Cf. também "Alvará de criação do novo governo de S. Paulo, de 2 de dezembro de 1720." In: Documentos Interessantes para a História e Costume de São Paulo. Vol. XLVII. São Paulo: Casa Vanorden, 1929. p. 94-95-96. 


\section{CAPÍTULO 2}

\section{A VILA DE SÃO FRANCISCO DAS CHAGAS DE TAUBATÉ}

O presente capítulo tem por objetivo lançar luz sobre as características do universo espaço-temporal no qual estavam inseridas as atividades sertanistas e seus coadjuvantes. Tão importante quanto o estudo do objeto principal é o conhecimento da configuração de seu contexto histórico. Se isolados, objeto e contexto não adquirem a forma apropriada enquanto fruto de uma pesquisa histórica científica. Dessa maneira, pretende-se, aqui, discorrer sobre a região do vale do rio Paraíba, a sua exploração e o seu povoamento, buscando dar ênfase ao crescente interesse em desbravá-la, interesse esse despertado tanto nos colonos que habitavam as redondezas, como nos funcionários régios. Pensa-se na possível existência de uma relação entre as motivações iniciais do desbravamento do vale e o curso histórico tomado pelas povoações ali estabelecidas. Em seguida, tratar-se-á da fundação da vila de Taubaté e as suas principais características sociais, políticas e econômicas. Somente após a exposição do panorama geral da vila é que será possível identificar e caracterizar os indivíduos envolvidos nas atividades sertanistas, bem como medir a importância de tais empreendimentos para a vida da sociedade taubateana.

\subsection{Vale do rio Paraíba: exploração e povoamento}

A região conhecida como o vale do rio Paraíba, hoje pertencente aos Estados de São Paulo e Rio de Janeiro, é a área correspondente a esta pesquisa. Logicamente que não ela toda, o que significaria uma extensão demasiadamente grande. Escolheu-se a parte denominada como "médio vale do Paraíba", evidentemente, devido à localização da antiga vila e atual cidade de Taubaté que se encontra neste recorte espacial. A fim de melhor definir tal espaço, entende-se por médio vale

(...) toda área drenada por esse rio desde o seu grande cotovelo, em Guararema até a zona em que, recebidos os primeiros afluentes de importância (Piabanha-Preto e Paraibuna-Preto), começam as grandes corredeiras denunciadoras de sua rápida descida do planalto. Aí, nessa zona, já não encontraremos mais as altas elevações da Mantiqueira que enquadram, ao norte, o médio curso do rio. ${ }^{147}$

147 AB'SABER, Aziz Nacib; BERNARDES, Nilo. Vale do Paraíba, Serra da Mantiqueira e Arredores de São Paulo. Conselho Nacional de Geografia: Rio de Janeiro, 1958. p.74. 
Como o próprio nome já diz, a região é constituída por um vale que forma um corredor natural ligando por terra São Paulo ao Rio de Janeiro. Tal vale está localizado entre os dois famosos paredões, as serras do Mar e a da Mantiqueira, e que por isso mesmo coloca à sua disposição as águas do rio Paraíba que por ele corre. A importância deste rio foi creditada à considerável influência exercida na ocupação da área - o que se verá a seguir - e que, aliás, muitos anos mais tarde, ainda era tido como um dos rios de maior relevância. ${ }^{148}$ Vale lembrar que a referência dada aqui à ocupação diz respeito tanto aos silvícolas, que há muito já habitavam o local, quanto aos brancos que progressivamente foram se instalando logo depois da década de 1620. Porém, antes mesmo de qualquer indício de fixação da população branca no médio vale do Paraíba, a atração exercida por este território chamou a atenção de muitos aventureiros que por aí transitaram.

Pouco se tem de específico na historiografia sobre o devassamento do vale, não mais que algumas páginas, mas o que há está em harmonia em si quanto ao início das incursões mato a dentro. São unânimes em registrar que houve muitas entradas sertanistas que percorreram tal sertão já desde as últimas décadas do século XVI. Discordam, no entanto, em relação a suas intencionalidades, variando ora como empreendimentos de guerra e preamento indígena, ora como empresa de prospecção. Para a presente pesquisa, procurou-se pensar as expedições sertanistas como molas propulsoras da colonização portuguesa, sem fazer distinção entre as suas práticas e suas intencionalidades, mesmo porque era caçando o índio ou investigando possíveis jazidas de metais preciosos, que o sertão ia sendo desbravado. Assim, de forma geral, percebe-se que as entradas sertanistas poderiam até ter um objetivo definido, porém, uma vez no isolamento do sertão, as necessidades ou mesmo as oportunidades exerciam pressões que moldavam as suas ações. Nesse sentido, compartilha-se das palavras de José Bernardo Ortiz:

\footnotetext{
${ }^{148}$ Responsável por elaborar um quadro estatístico da Província de São Paulo, o Marechal Daniel Pedro Müller assim escreveu sobre o rio Paraíba: "Na enumeração dos rios mais notáveis da Província se tracta primeiro do Parahyba, que fica a Leste, o qual tirando suas origens da Serra do Mar, e Bocaina, corre a Oeste, e depois voltado a Nordeste, com a singularidade de passar depois de dilatado curso, pouco distante das suas vertentes, vae atravessar parte da Província do Rio de Janeiro, pelos Campos dos Goytacazes, desaguando no mar perto da Cidade de S. Salvador de Campos. Os principaes ramos d'este rio são o Paraitinga, e o Paraibuna. É navegável em grande parte, sendo as cachoeiras de maior consideração a da Fortaleza, perto da Vila de Rezende, e outra pouco adiante d'esta chamada do Inferno." MÜLLER, Daniel Pedro. Ensaio d'um Quadro Estatístico da Província de S. Paulo. Reedição. São Paulo: Governo do Estado, 1923. p.11.
} 
Eram expedições que buscavam, via de regra, escravos índios para trabalhar nas sesmarias e fazendas combatendo os gentios mais rebeldes, inclusive tamoios e geromimis (guarumimis ou Guarulhos) que acometiam periodicamente as povoações colonizadoras. Paralelamente pesquisavam possíveis regiões auríferas atravessando o vale em demanda das gargantas de Piracuama, Piquete ou Embaú e faziam o reconhecimento de novas terras que servissem ao estabelecimento de propriedades agro-pastoris. ${ }^{149}$

Acrescenta-se que tais expedições poderiam não seguir nesta ordem proposta por Ortiz, como se verá adiante.

Tem-se notícias de algumas entradas efetuadas no sertão do vale que datam da década de 1560. A dificuldade é muito grande em precisar tanto as datas quanto o volume delas, muito mais árduo também seria pensar em descrevê-las minuciosamente devido à pouquíssima documentação existente para o período, e o que se tem são basicamente informações esparsas na bibliografia consultada, além de alguns relatórios e diários de oficiais régios, homens do governo e viajantes.

As incursões conhecidas podem ser enumeradas. Houve, em fins de 1561, uma entrada comandada por Brás Cubas na qual esteve presente um mineiro chamado Luís Martins. Dúvidas existem quanto ao seu ponto de partida, ou seria de Santos ou de São Paulo. Passou por Mogi das Cruzes, desceu pelo rio Paraíba até a paragem de Cachoeira, local onde encontraram o caminho que atravessa a serra da Mantiqueira em direção aos sertões dos Cataguás. Sobre a sua intencionalidade "dizem que tal jornada exploradora, em direção ao S. Francisco, foi mesmo combinada em S. Vicente por Mem de Sá, para busca de riquezas metálicas. ${ }^{150}$ No entanto, como já apontado, a guerra e caça de índios também figuravam entre as ações sertanistas, como exemplo disso, vê-se que este mesmo governador travou combates com os primitivos habitantes do vale. ${ }^{151}$ Testemunha disso, o padre Manuel da Nóbrega, em uma carta datada de $1^{\circ}$. de junho de 1560 , envolve o nome de Mem de Sá no complexo processo de conversão dos indígenas. Nela o padre diz que as

${ }^{149}$ ORTIZ, José Bernardo. São Francisco das Chagas de Taubaté. Tomo II. Taubaté: Prefeitura Municipal, 1996. p. 23.

150 ABREU, Waldomiro Benedito de. Pindamonhangaba: tempo e face. Aparecida: Editora Santuário, 1977. p. 94.

151 "Tal guerra se dirigia contra os selvícolas do Paraíba e originou a entrada sob comando de Jorge Moreira, da qual o padre José de Anchieta participou como intérprete, de tudo advindo maior tranqüilidade para os colonos litorâneos e de S. Paulo." Cf. Idem, Ibidem. p. 94. 
coisas em relação à conversão dos índios na capitania de São Vicente estão melhores no governo de Sá, mas ainda tem-se que vencer a

contradição de todos os cristãos desta terra, que era quererem que os indios se comessem, porque nisso punham a segurança da terra; $e$ quererem que os índios se furtassem uns aos outros, para eles terem escravos; e querem tomar as terras aos índios contra razão e justiça, e tinarizarem-nos por todas vias; e não querem que se juntem para serem doutrinados (...). ${ }^{152}$

Ora, colonização e exploração denotam esforços primários como desbravamento, conflitos, prejuízos financeiros e humanos, enfim, é a velha dicotomia prevista na História: a convivência dos conflitos e das acomodações.

Outras incursões foram feitas ao longo dos anos. Conhecidas ou não, deduz-se que, por volta do ano de 1580, "findara a conquista da região compreendida entre a Mantiqueira, em S. Paulo, e a serra do Mar." ${ }^{153}$ Mas isso não quer dizer que a exploração da região chegara ao seu estágio de consolidação. Uma vez amenizado o problema dos ataques inimigos, buscou-se conhecer cada vez mais as potencialidades naturais do local visado e de suas redondezas. Talvez por isso que se ainda mantinha em alta as incursões.

A década de 1590 foi especial nesse contexto. Seu diferencial fica por conta da chegada do sétimo Governador Geral do Brasil, D. Francisco de Sousa. Tido como o "patriarca do bandeirismo", coube a ele "a primeira organização razoável para a prospecção metódica e inteligente das riquezas minerais brasileiras (....). ${ }^{, 154}$ Muito conhecido por seu fascínio pelos mistérios do sertão, e como grande sonhador de minas repletas de metais e pedras preciosas, suas ações foram voltadas, desde o início de seu governo, para a organização de expedições de prospecção.

Em princípio, suas medidas foram postas em prática sob sua própria intervenção. As primeiras entradas partiram da Bahia, sede do Governo Geral. Muitas destas foram alimentadas pelas informações vindas dos próprios índios e de outros colonos que ainda mantinham frescas na mente a famosa aventura de Gabriel Soares de Sousa, um rico proprietário de terras e escravos que, em 1587, penetrou os sertões e encontrou ouro, em

152 "De uma carta do padre Manuel da Nobrega, que escreveu ao Ilm. Cardeal; de São Vicente, o $1^{\circ}$. de Junho de 1560". In: R.I.H.G.B. Vol. 19, outubro de 1843. Rio de Janeiro: Typographia Universal de Laemmert. p. 352-353.

${ }^{153}$ ABREU, Waldomiro Benedito de. Op. cit. p. 99.

${ }^{154}$ TAUNAY, Afonso de E. História das Bandeiras Paulistas. Tomo I. $2^{\text {a }}$. ed. São Paulo: Edições Melhoramentos, 1961. p. 16 e 153. 
pouquíssima quantidade, a bem da verdade. ${ }^{155}$ Pouco frutíferas, tais expedições geravam muitos gastos. Mas, se por um lado as coisas não iam muito bem via região Nordeste, mais ao Sul surgiam boatos animadores sobre o achamento de minas de metais preciosos, isto é, “corria a fama de que no litoral paulista havia copioso ouro.",156

Importa ressaltar que a exploração aurífera na Capitania de São Vicente era pouco rentável, mas o seu verdadeiro valor correspondia a sua própria existência, o que denotava a possibilidade de haver mais minas a serem descobertas. ${ }^{157}$ Assim, "não há melhor indício de que as jazidas de metal, embora pobres, eram aqui uma realidade, e capaz de impor-se à atenção dos agentes da Coroa." "158 Atenção que foi despendida por D. Francisco de Sousa, que, ansioso por melhores resultados, veio conferir de perto os trabalhos dos pesquisadores.

Porém, antes de vir às capitanias do Sul, mandou que se fizessem algumas entradas a fim de averiguar a veracidade dos boatos. Em 1596, João Pereira de Sousa Botafogo adentrou os sertões do vale do Paraíba. No ano seguinte, ocorre a famosa viagem de Martim de Sá juntamente com o inglês Antonio Knivet que também percorreu o vale e chegou a atingir a área denominada "sertão dos Cataguás." Felizmente, chegou até os dias

\footnotetext{
${ }^{155}$ Pedro Calmon além de descrever a famosa entrada de Gabriel Soares, mostra como ele estava bastante ligado ao círculo governamental ao solicitar títulos e direitos oficiais sobre tal empresa. Diz ele: "vimos Gabriel Soares em Espanha desde 1584, a pleitear a concessão, para reforço da qual, sem dúvida, escreveu - minucioso roteiro do Brasil - o seu livro sobre a geografia e a colonização da América Portuguesa. A base dos planos era o itinerário descrito por João Coelho de Sousa. Obteve o título de 'capitão-mor e governador da conquista e descobrimento do Rio de São Francisco', com o direito de nomear os oficiais administradores no seu distrito, duzentos índios frecheiros que o governador-geral lhe daria, para quatro cunhados e dois primos, o hábito de Cristo com 50\$000, e mais doze para os que o acompanhassem, autorização para outorgar o foro de cavaleiro fidalgo a cem pessoas. Tais vantagens, e a obsessão do São Francisco, revelam o intuito de Gabriel Soares, que era achar as nascentes do rio onde - no paralelo das minas do Peru - lhe parecia deverem estar as jazidas lendárias do 'Dorado'." Continua: "não houve minas descobertas, nem as nascentes do São Francisco, nem vestígios da civilização primitiva que se escamava de puro ouro à beira do lago fantástico - da Guiana, o Eldorado." CALMON, Pedro. História do Brasil. Vol. II. 2a ${ }^{\text {a }}$ Ed. Rio de Janeiro: José Olympio, 1963. p. 423 e 425.

${ }^{156}$ TAUNAY, Afonso de E. Op. cit. p. 28.

${ }^{157}$ A falta de precisão nos dados referentes à quantidade da produção mineral é uma preocupação constante entre os estudiosos do assunto devido à inexistência ou a parcialidade da documentação coeva. Embora os largos esforços destes, o máximo que se tem são números de aproximação e, ainda assim, bastante variados. Cf. OLIVEIRA, Álvaro de Sales. "Produção do Ouro no Brasil." In: R.I.H.G.S.P. Volume XXXVII, 1939. São Paulo: Typographia do Diário Oficial, 1939. p. 195-202. ${ }^{158}$ HOLANDA. Sérgio Buarque de. "A Mineração: antecedentes Luso-brasileiros". In: História da Civilização Brasileira. Tomo I, Vol. 2. Rio de Janeiro: Bertrand, 1989. p. 248.
} 
atuais um diário de viagem feito por knivet que detalha passo a passo o caminho percorrido por eles e que mais adiante se verá com maior atenção. ${ }^{159}$

Já no ano de 1598 “(...) visitava o Governador as capitanias do sul até São Vicente, onde providenciou sobre explorações em várias partes do sertão."160 Duas expedições devem ser destacadas aqui: a de André de Leão e a de Nicolau Barreto, postas em prática em 1601 e 1602, respectivamente. Ambas percorreram o vale do Paraíba e tinham, claramente, o objetivo de prospecção, pois buscavam pela lendária mina de Sabarabuçu, mas nada teve de satisfatório tais empreendimentos. ${ }^{161}$

Inspirador de tais entradas, iludido ou não com o sonho das minas, D. Francisco de Sousa teve parte considerável no processo de devassamento do vale do rio Paraíba. Sabido de que era por essa região que se podia alcançar o território das tão desejadas minas, tal governador contribuiu para o aumento do fluxo migratório, abrindo e ampliando caminhos que facilitavam a circulação de pessoas por essas bandas. Cresce assim, o interesse pelo vale.

A formação dos caminhos são vestígios da circulação de pessoas, sejam elas indígenas ou brancas. Existiram três grandes: 1) o chamado "caminho dos Guaianás", que foi aberto pelos selvagens desse nome que fazia comunicação entre os campos de Piratininga e o litoral fluminense. Esta foi a única via nos séculos XVI e XVII entre o Rio de Janeiro e o interior paulista e a região dos Cataguás. No final do século XVII, ficou conhecido como "caminho velho" e unia Parati ao lugar denominado Facão (hoje município de Cunha), bifurcando-se para Taubaté e Guaratinguetá. Desta última, prosseguia até as "roças de Bento Rodrigues", em Guapacaré (Lorena), atravessando o Paraíba, nas alturas de Cachoeira, bem como o Embaú, na Mantiqueira, e penetrando nas Minas; 2) um caminho litorâneo, também aberto pelos índios, ligava Parati, Ubatuba, Natividade, Paraibuna e

159 KNIVET, Anthony. As Incríveis Aventuras e Estranhos Infortúnios de Anthony Knivet. São Paulo: Companhia das Letras, 2007.

${ }^{160}$ POMBO, Rocha. História do Brasil. 4a. Ed. São Paulo: Companhia Melhoramentos, 1941. p.144. A pressa de D. Francisco também está registrada em outros textos. "Logo a chegada a São Paulo de Dom Francisco de Sousa, cuidou ele de enviar expedições ao sertão, que averiguassem a veracidade das lendas da existência de metais nas colônias portuguesas." ELLIS JR., Alfredo. $O$ Bandeirismo Paulista e o Recuo do Meridiano. 2a . Ed. São Paulo: Companhia Editora Nacional, 1934. p.83.

${ }^{161}$ Para Pedro Calmon, "levara André de Leão instruções para a pesquisa de minas no sertão." CALMON, Pedro. Op. cit. p.453. 
Mogi das Cruzes; e 3) o "caminho dos paulistas", também chamado de "caminho geral do sertão", era a estrada geral de São Paulo às Minas, seguindo o mesmo itinerário do Embaú. ${ }^{162}$

Waldomiro Benedito de Abreu estipulou uma espécie de quadro cronológico a fim de facilitar o entendimento do processo de colonização do vale e as suas diferentes etapas. Para ele os períodos se organizam da seguinte forma: de 1560 a 1580 corresponde ao momento de reconhecimento e domínio do vale; de 1585 a 1620, período de consolidação dessas providências e, de 1620 em diante, o de colonização e exploração econômica. A grosso modo, esta divisão segue uma lógica própria do movimento de colonização portuguesa, e, ainda que se questione os períodos estipulados, ratifica-se aqui o que acima se mostrou. Variações nos anos, para mais ou para menos, não alteram o processo em si. E tais alterações podem até ser trazidas à tona como, por exemplo, o que diz Benedito Calixto: para ele Martim Afonso de Sousa mandou uma bandeira para "explorar a bacia do vale do Paraíba até as encostas da Mantiqueira", ou seja, defende que a exploração teria começado já na primeira metade do século XVI. ${ }^{163}$ Sérgio Buarque de Holanda também mostrou como as datas muitas vezes são imprecisas. Holanda escreveu referindo-se ao vale que "só para o período que vai de 1608 a 1612 existem documentadas dezesseis petições ou concessões de sesmarias na mesma paragem", mostrando com isso que a instalação de colonos iniciara logo no início do seiscentismo. ${ }^{164} \mathrm{Na}$ documentação compulsada, a data mais antiga referente à ocupação da área valeparaibana é de 1628, correspondente a uma carta de sesmaria dada pelo Capitão-mor João de Moura Fogaça a Manoel Vieira Sarmento. ${ }^{165}$ Além desta concessão, há o famoso documento passado pelo mesmo Capitãomor ao responsável pela povoação, Jacques Félix, que também data de $1628 .{ }^{166}$ Ambos cedem terras nas proximidades de onde, mais tarde, se formará o núcleo da ocupação.

162 Pode-se acrescentar mais uma rota, o chamado "Caminho Novo" aberto por Garcia Rodrigues Pais aberto após as descobertas das minas de ouro que ligava o Rio diretamente às Minas. Tais informações foram obtidas em ABREU, Waldomiro Benedito de. Op. cit. p. 92.

${ }^{163}$ CALIXTO, Benedito. "Capitanias Paulistas". In: R.I.H.G.S.P. Vol. 21, 1924. p. 256.

${ }^{164}$ HOLANDA, Sérgio Buarque de. "Caminhos do Sertão." In: Revista de História. São Paulo: Janeiro-Março, Vol. XXVIII, n.57, ano XV, 1964. p. 95.

${ }^{165}$ Inventário de Manoel Vieira Sarmento (1720). Cx: 1720-1723. Arquivo Histórico Municipal de Taubaté.

${ }^{166}$ Para a leitura do documento na íntegra Cf. GUISARD FILHO, Félix. Jacques Félix: achegas à História de Taubaté. São Paulo: Athena Editora, 1938. p. 15-16. 
Com a crescente importância do vale, aumenta-se o interesse não somente dos colonos, mas também dos oficiais régios. Além disso, os conflitos em torno da posse e da jurisdição, tão comuns no Brasil colônia, passam a ocupar bastante espaço nas discussões. A questão da legitimidade da herança e as dificuldades de definição das fronteiras são os principais motivos de discordância entre os envolvidos em libelos. O mais famoso deles, e que aqui, particularmente, é peça fundamental para o melhor entendimento do processo histórico sobre o vale do Paraíba, é o atrito entre os Vimieiros e os Monsantos.

Durante o regime inicial das Capitanias Hereditárias ${ }^{167}$, Martim Afonso de Souza foi agraciado com uma enorme faixa de terras que foi denominada Capitania de São Vicente. Esta se estendia de Macaé, localizada ao norte de Cabo Frio, até a Ilha do Mel, aproximadamente ao norte de Paranaguá. Estranhamente, seu irmão, Pero Lopes de Souza, recebeu uma seção de terras que ficava dentro de suas posses. Tal seção compunha dez léguas de costa e começava ao norte de São Sebastião, mais precisamente no rio Juqueriquerê, terminando na barra de Bertioga. Esta faixa de terras foi chamada de Capitania de Santo Amaro. Há quem acredite que esta original composição tenha seus motivos específicos e que definiram o curso dos acontecimentos. Essencialmente, "a razão desse capricho real, na distribuição das Capitanias desses famosos irmãos, residia em que, na época de sua criação, já era conhecida a existência de minas de metais preciosos, no interior dos sertões." 168 Insinua-se com isso que tal divisão assim feita teve por objetivo evitar uma possível injustiça ao ficarem as minas incluídas dentro de uma só capitania.

Posteriormente, os problemas começaram a surgir entre os herdeiros dos donatários. De um lado os senhores de Monsanto e de Cascais, como herdeiros de Pero Lopes de Souza, e de outro lado, a Condessa de Vimeiro, herdeira de Martim Afonso de Souza. Muitos problemas judiciais que questionavam a legitimidade das posses, inclusive baseadas na fragilidade das demarcações territoriais, fizeram com que a seção de terras atribuída à

\footnotetext{
${ }^{167}$ Sobre os fundamentos históricos que levaram à criação das Capitanias Hereditárias no Brasil e a estrutura legal, política e econômica que as sustentaram, Cf. SALDANHA, António Vasconcelos de. As Capitanias do Brasil: antecedentes, desenvolvimento e extinção de um fenómeno atlântico. Lisboa: Comissão Nacional para as Comemorações dos Descobrimentos Portugueses, 2001.

${ }^{168}$ ABREU, Waldomiro Benedito de. Op. cit. p. 104. Outro autor também compartilha da mesma idéia. Para Bernardo Ortiz, "o motivo dessa estranha divisão deve estar relacionado com o fato dos irmãos donatários já terem notícia, àquele tempo, da existência de minas preciosas no interior dos sertões das áreas doadas." ORTIZ, José Bernardo. São Francisco das Chagas de Taubaté. Tomo I. Taubaté: Prefeitura Municipal, 1996. p. 511.
} 
Capitania de Santo Amaro aumentasse, englobando algumas vilas como a de São Paulo, Santos e até mesmo a vila capital São Vicente. ${ }^{169}$ Novamente, os interesses na conquista das tão cobiçadas minas de pedras e metais preciosos estavam, supostamente, em jogo. ${ }^{170}$

Foi nesse contexto de flutuações nas posses e jurisdições territoriais que a Capitania de Santo Amaro se apossou do título de Capitania de São Vicente. Assim, caberia à Condessa de Vimieiro, após perder a vila de São Vicente em 1624, transferir a sede de sua Capitania à antiga vila de Nossa Senhora da Conceição de Itanhaém, nome que também passou a ser dado a sua possessão.

Importa registrar que grande extensão das terras do vale do Paraíba estava sob posse da Condessa. E após o prejuízo tido no processo com os Monsantos, esta região passou a guardar especial atenção de sua donatária. A ação deliberada de tomada efetiva de posse por meio da fundação de vilas, neste caso, a de Taubaté, esteve entre as medidas assumidas pela Condessa a fim de maximizar a exploração de suas posses. Tais questões serão discutidas a seguir.

\subsection{A Fundação da Vila de Taubaté}

Reafirma-se que a pretensão de discorrer sobre o desbravamento e ocupação do vale do Paraíba, e conseqüentemente sobre a fundação de Taubaté, primeira vila da região, tem a ver com o objetivo de analisar as possíveis relações entre as intencionalidades evidenciadas no processo inicial de colonização e, depois, com a configuração encontrada na dinâmica da vila. Isto é, questiona-se o quanto que o rumo tomado pela vila referente às suas atividades econômicas e sociais pode estar ligado às suas raízes.

\footnotetext{
${ }^{169}$ Em obra datada de 1772, Pedro Taques investigou a História da Capitania de S. Vicente. Este trabalho foi feito a pedido do Sr. D. João de Faro, principal da Santa Basílica Patriarcal do Conselho de Sua Majestade. Tal pesquisa visou resolver o problema da posse da Capitania entre o Conde de Monsanto e a Condessa de Vimieiro. O autor, por fim, defende a legitimidade da posse da Condessa. Cf. LEME, Pedro Taques de Almeida Paes. História da Capitania de S. Vicente. São Paulo: Ed. Melhoramentos, s/d. Para uma síntese de todo esse processo judicial cf. SILVA, Maria Beatriz Nizza da (org.). História de São Paulo Colonial. São Paulo: Editora UNESP, 2009. Em especial o capítulo "São Vicente, capitania donatarial (1532-1709)". p.13-88.

170 "Os herdeiros de Pero Lopes de Souza, senhores de Monsanto e de Cascais, se empenhavam assim em apoderar-se da vila de S. Paulo, a fim de fazerem dela a sede de sua Capitania de Santo Amaro, em esperança de que seria, desse ponto, que se haviam de irradiar as 'linhas de roteiro', na conquista das brenhas, que ainda ocultavam as tão cobiçadas minas de pedras e metais preciosos." ABREU, Waldomiro Benedito de. Op. cit. p.105.
} 
Como mostrado anteriormente, a donatária da Capitania de São Vicente, agora chamada de Itanhaém, após perder parte importante de suas posses, passou a dar maior atenção aos territórios que "prometiam" certa prosperidade. ${ }^{171}$ Nesse sentido, "a ocupação da região valeparaibana, se intensificou quando a Condessa de Vimieiro ordenou o povoamento oficial das terras e sertões do Paraíba, com distribuição, registro e posse de sesmarias." ${ }^{\prime 172}$ Veja-se que dois pontos merecem destaque: primeiro a própria ocupação do vale como resultado deliberado; e segundo o caráter oficial dela.

Apesar da situação privilegiada em termos geográficos, o vale, naquele tempo, ainda não possuía nenhuma edificação significante, muito menos a posse oficial materializada evidentemente na fundação de vilas. Há muito tempo conhecido, principalmente pelas possibilidades de acesso aos sertões que escondiam as riquezas minerais, o vale só foi definitivamente pensado como setor de povoamento a partir da década de 1620, intensificando-se na seguinte, mesmo porque “(...) a conveniência dessa ocupação passava a interessar vivamente as autoridades, atentas, talvez, às vozes correntes sobre a presença ali de minas de ouro."173

Personagem principal nesta história, Jacques Félix, o moço, foi o responsável por colocar em prática os planos idealizados pela donatária de Itanhaém. ${ }^{174}$ Seus atributos não se restringiam apenas por ser considerado um "homem bom", mas mais ainda por ser

171 "D. Mariana de Sousa da Guerra, a Condessa de Vimieiro, após haver perdido a faixa de sua capitania precisava criar meios para fazer prosperar o restante de terras que lhe tocavam." MARTINS, Gilberto. Taubaté nos seus Primeiros Tempos. Taubaté: Empresa Gráfica Editora Taubaté, 1973. p. 40.

${ }^{172}$ ABREU, Maria Morgado de. Taubaté: de núcleo irradiador de bandeirismo a centro industrial e universitário do vale do Paraíba. 2a . ed. Aparecida: Editora Santuário, 1991. p. 17.

${ }^{173}$ HOLANDA, Sérgio Buarque de. Op. cit. p. 101.

174 "Jaques Félix: paulista, segundo alguns filho do precedente [Jaques Félix, o flamengo] e segundo outros, filho de Belchior Félix Perestelo, casado em 1575, em Santos, com uma filha de Jerônimo Dias. Jaques Félix casou-se em São Paulo com Francisca Morzillo, filha do sertanista João Morzillo. Em 1598, dizendo-se morador antigo dessa vila, com filhos, obteve sesmaria no caminho de Ibirapuera. Tomou parte na bandeira de Tenório de Aguilar, aos bilreiros, saindo de São Paulo em 1608 e, destroçada a leva, apareceu de regresso em 1610. Exerceu cargos na câmara da vila e obteve outras sesmarias, em 1616, 1628 e 1632. Com seus filhos, combateu índios guarumimís ou guarulhos, puris e caetés, que ficavam em território atualmente de Minas-Gerais, na vertente de além Mantiqueira, no alto Sapucaí. Explorou também grandes tratos do vale do rio Paraíba, onde em 1636 fundou um arraial, no antigo local de uma aldeia indígena e que tomou por isso nome de Taubaté. Em novembro de 1640 já era falecido, deixando geração.” FRANCO, Francisco de Assis Carvalho. Dicionário de Bandeirantes e Sertanistas do Brasil. São Paulo: Comissão do V Centenário da Cidade de São Paulo, 1954. p. 149. 
grande conhecedor das terras banhadas pelo rio Paraíba, percorridas por ele desde o início do século XVII. ${ }^{175}$ Também é possível que tenha transpassado o enorme paredão da Mantiqueira, atingindo os sertões que guardavam as minas encobertas, mas, como acredita Sérgio Buarque de Holanda, já suspeitadas. ${ }^{176}$

Experimentado nos mistérios do sertão, foi escolhido para implantar a posse oficial através da fundação de um povoado numa área muito bem localizada, lugar de uma antiga aldeia guaianá, conhecida como a bacia sedimentar de Taubaté, "o mais amplo dos compartimentos de relevo do vale do Paraíba."177

O próprio nome "Taubaté” designa a presença primitiva de índios. Apesar de variar muito nos registros documentais, as duas principais hipóteses para o termo são as seguintes: 1) Taba (aldeia, povoação) e eté (verdadeira, legítima, antiga), significando aldeia legítima ou verdadeira, ou mesmo aldeia antiga; e 2) Taba (aldeia, povoação) e ibaté (alta), significando aldeia alta. É difícil precisar o verdadeiro significado. ${ }^{178}$ Parecem ser as duas versões bastante convincentes, a primeira porque pode se referir a uma aldeia central, a principal entre todas as outras que existissem pela região, e a segunda porque se sabe, hoje, que tal povoação se localizava na encosta de uma colina. De qualquer forma, é interessante notar que a implantação da futura vila feita pelos brancos seguiu a orientação espacial traçada pelos seus antigos moradores, tanto que o nome Taubaté acabou sendo emprestado a ela. Atualmente, é bastante conhecido o forte envolvimento entre a cultura indígena e a européia no mundo colonial, com destaque para predominância de costumes primitivos praticados pelos índios em relação ao conhecimento geográfico, alimentício, estratégias militares e entre outros, que foram adotados pelos colonos. ${ }^{179}$

${ }^{175}$ Félix Guisard Filho defende que Jacques Félix já percorria o vale desde 1604. Cf. GUISARD FILHO, Félix. Op. cit. p.12-13.

${ }^{176}$ HOLANDA, Sérgio Buarque de. Op. cit. p. 96.

${ }^{177}$ AB'SABER, Aziz Nacib; BERNARDES, Nilo. Op. cit. p. 87.

${ }^{178}$ Para Diogo de Vasconcelos, por exemplo, "o sinal de plural entre os índios era - eté, aita, ou etá. Assim Tabua-eté significa Tabua-muita, ou tábuas. Era uma cana das tifacéias (typha-minor), com que se faziam esteiras. Sertão de Tabuaté, pois, queria dizer Sertão das Tábuas." VASCONCELOS, Diogo de. História Antiga das Minas Gerais. $3^{\mathrm{a}}$. ed. vol. 1. Belo Horizonte: Itatiaia; Brasília, INL, 1974. p. 71.

${ }^{179}$ Cf. HOLANDA, Sérgio Buarque de. Caminhos e Fronteiras. São Paulo: Companhia das Letras,

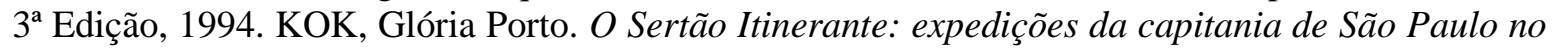
século XVIII. São Paulo: Hucitec: Fapesp, 2004. 
Quando se iniciaram as primeiras ações com vistas à instalação da vila, a população indígena não oferecia mais perigos, e mesmo um pouco antes, “(...) já na primeira década seiscentista esses silvícolas do Vale do Paraíba encontravam-se, em grande parte, aldeados ou cativos. Os grupos remanescentes, 'não reduzidos', foram rapidamente dizimados ou fugiram pra outras regiões." ${ }^{180}$ Portanto, o caminho estava livre para a exploração da área.

De acordo com o raciocínio de John M. Monteiro, muitas expedições penetraram o vale do Paraíba e "este movimento acarretou a fundação na região de novas vilas por pioneiros paulistas, sendo que nos anos 1640-50 foram instalados pelourinhos em Taubaté, Guaratinguetá e Jacareí." Assim, "o desenvolvimento de cada uma dessas vilas refletia as novas orientações da busca pela mão-de-obra indígena." ${ }^{181}$ Nesse sentido, a ocupação desta extensa área teria sido o resultado direto tanto do desenvolvimento econômico da capitania como da crescente necessidade por terras e mão-de-obra. Tal linha de pensamento é bastante convincente, aliás, muito bem traçada e defendida em sua obra. Do ponto de vista do colono, isto é, da dinâmica interna da colônia esta tese se sustenta fortemente, sendo amplamente aceita. No entanto, pensa-se para a presente dissertação, numa análise através da vertente externa, ou seja, do lado dos agentes oficiais da colonização, isto sem querer contrariar as opiniões de Monteiro, antes complementá-las.

Em se tratando do processo de fixação do povoamento, defende-se, portanto, que pode ter sido o resultado de "ações deliberadas". Como já exposto atrás, após sofrer perdas, a Condessa de Vimieiro, donatária da capitania de Itanhaém, promoveu a maximização da exploração das terras que ainda lhe restavam, e o vale do Paraíba era o foco principal. Pode-se enumerar três documentos que comprovam o caráter oficial deste processo. ${ }^{182}$

O primeiro deles, datado de 20 de janeiro de 1636, foi concedido por Roque de Gouveia, então Capitão-mor da vila de Nossa Senhora da Conceição de Itanhaém, ao capitão Jacques Félix, dando instruções sobre a povoação que foi encarregado de fundar,

\footnotetext{
${ }^{180}$ REIS, Paulo Pereira. O Indígena do Vale do Paraíba. São Paulo: Governo do Estado, 1979. p. 34.

${ }^{181}$ MONTEIRO, John Manuel. Negros da Terra: índios e bandeirantes nas origens de São Paulo. São Paulo: Companhia das Letras, 1994. p. 81-82. Em outro trecho, Monteiro afirma que, "reagindo a uma crise no abastecimento de cativos guarani, a partir de 1640 os colonos de São Paulo, Parnaíba e Mogi das Cruzes passaram a reorientar suas expedições para o vale do Paraíba, onde as vilas de Taubaté (1643), Guaratinguetá (1651) e Jacareí (1653) logo brotaram.” p. 109.

${ }^{182}$ As informações foram extraídas de ORTIZ, José Bernardo. Op.cit. p. 06-07.
} 
discorrendo também sobre as regras que deveriam ser seguidas quanto às concessões e demarcações das sesmarias oferecidas.

O segundo, com data de junho de 1639, é um despacho do governador e sesmeiro da capitania de Itanhaém, Vasco da Mota. Nele, há a concessão de um prazo de seis meses para os povoadores ocuparem as terras, referindo-se ao interesse da donatária e também de Sua Majestade em fundar a mencionada povoação.

E por último, um alvará de 13 de outubro de 1639, assinado novamente por Vasco da Mota. Contém informações sobre as demarcações que deveriam ser feitas na paragem de “Tabebaté”, inclusive uma légua de terras para aí estabelecer o rocio da nova povoação.

Por meio de tais informações, constata-se que o governo da capitania e a Coroa estavam cientes do que acontecia nessas terras, guardadas as distâncias espaço-temporais entre os acontecimentos e o transporte das notícias. Interesses existiam, necessidades também. Seria muito válido pensar na questão do caráter oficial desse empreendimento. Sabe-se que, como visto até agora, Jacques Félix “(...) como procurador bastante da Condessa donatária, de Vimieiro, penetrou oficialmente os sertões, aumentando, assim, conforme às ordens da metrópole, o conhecimento das terras da referida condessa."183 Sabe-se também que havia notícias de que a região do vale, pertencente à condessa, oferecia condições de penetração em sertões que escondiam minas de metais preciosos. Ora, é correto então pensar a colonização do vale e, principalmente, a fundação de Taubaté como uma ação oficial? Acredita-se que sim, conforme também cogitou Sérgio Buarque de Holanda.

Para Holanda, as notícias da presença de minas, ou mesmo de caminhos que permitiam o acesso a elas, eram as principais motivações para a ocupação do vale. Assim,

a obra de exploração e povoamento de toda aquela região pode equiparar-se a uma empresa metodicamente governada pela certeza de que se encontrariam riquezas prenunciadas ou já entrevistas durante a administração de D. Francisco de Sousa. ${ }^{184}$

Levando em consideração o que sugere este autor, deve-se situar a fundação de Taubaté no contexto deste processo. Feito isso, a presente pesquisa passa a entender as atividades sertanistas, tanto de caça ao índio quanto o de prospecção, como elementos que

${ }^{183}$ GUISARD FILHO, Félix. Convento de Santa Clara: achegas à História de Taubaté. São Paulo: Editora Athena, 1938. p.11.

${ }^{184}$ HOLANDA, Sérgio Buarque de. Op. cit. p. 110. 
formam a base das intenções existentes no processo de exploração e consolidação do povoamento em terras valeparaibanas, o que pode levar a pensar na possibilidade de influência na dinâmica sócio-econômica daquele aglomerado que se formará ao longo dos anos.

Enfim, a elevação do povoado de Jacques Félix à categoria de vila, em 5 de dezembro de 1645, com o nome de São Francisco das Chagas de Taubaté, representa a materialização dos esforços, em princípio oficiais, no sentido de consolidar a posse da região, e mais, servir como ponto de apoio e sustentação das entradas sertanistas que demandavam as terras longínquas em busca dos sonhados metais preciosos.

Verificar as principais características da vila pode ajudar a compreender melhor o desenrolar do processo histórico que culminou no reconhecimento de Taubaté como um dos maiores pólos de irradiação sertanista do Brasil.

\subsection{Migração e Composição Social}

Em se trantando de estudos sobre migração, o ideal seria o levantamento de dados quantitativos, o que permitiria uma melhor avaliação da trajetória histórica da formação populacional da vila e um exame das possíveis variações do seu tamanho. Infelizmente, não se tem conhecimento da existência de documentação pertencente a Taubaté capaz de fornecer precisamente tais dados. Ao que se sabe, não houve durante o período estudado o registro formal dessa população, isto é, a formulação dos Maços de População, fonte esta que, de fato, é mais favorável ao uso de estudos demográficos. ${ }^{185}$ Visando contornar a situação, pensou-se na utilização dos registros de batismo e casamento que poderiam ajudar na reconstrução da realidade populacional de Taubaté, mas não foi possível haja vista que só existe um pequeno fragmento documental que contempla os bastismos de homens livres somente entre os anos de 1688 e 1704, ou seja, uma parcela miníscula frente ao período

\footnotetext{
${ }^{185}$ A segunda metade do século XVIII ficou marcada pelas ações de Sebastião José de Carvalho e Mello, o Marquês de Pombal, que buscava ampliar o conhecimento do Império português. Nesse sentido, era importante a compreensão da realidade das colônias e da própria metrópole para que pudessem ser elaboradas as reformas necessárias para a manutenção e engrandecimento do Império. Eram reformas administrativas, econômicas, sociais e políticas. Foi neste contexto que surgiram as primeiras tentativas de levantamentos censitários.
} 
avaliado pela presente dissertação. ${ }^{186}$ Sendo os inventários e os testamentos o corpo documental básico deste estudo, não foi possível, então, estipular números com relação a população já que este tipo de fonte não permite tal façanha. De qualquer maneira, buscouse indícios qualitativos dispersos na documentação compulsada e na bibliografia consultada que apontassem para a configuração da sociedade taubateana ao longo de sua história.

Dentro do recorte cronológico estabelecido para esta pesquisa, foi possível identificar dois momentos em que a configuração populacional da vila pode ter sofrido mudanças. O primeiro deles, logicamente, faz parte do período inicial de ocupação da região indo até os anos que antecedem a descoberta oficial das minas (1640 a 1680); em seguida, tem-se a década de 1690 e as duas primeiras do século XVIII que é quando se percebe maior movimentação de pessoas devida as oportunidades surgidas com a exploração do ouro nas Gerais.

Lembra-se que a intenção em registrar essas tendências mais marcantes em relação à circulação populacional ocorrida em Taubaté fica por conta da possível influência que tal mobilidade tenha gerado na estrutura social e econômica da vila, principalmente nos seus momentos de maior significância.

Antes, porém, de se tratar especificamente deste assunto, é nessessário reconhecer o caráter extremamente móvel da sociedade colonial. Apesar da existência de situações em que se presencia a maior ou menor movimentação dela, esta sempre houve. Sheila de Castro Faria mostrou que fluxo de colonos era muito corriqueiro a ponto de não causar estranheza naqueles que observavam tal deslocamento humano. Para ela,

o homem colonial era essencialmente migrante. O fluxo intenso de gente, a transitoriedade de residência, de ocupação e de fortuna, a aventura, as possibilidades de enriquecimento, a abertura de novas áreas de exploração, as lutas cotidianas e a rapidez das transformações eram as fortes características da sociedade colonial brasileira. ${ }^{187}$

Aspectos como a mobilidade, a dispersão e a instabilidade devem ser, inevitavelmente, consideradas como parte integrante da realidade colonial. Em referência a São Paulo, muito já se falou quanto a isso, seja nas palavras pioneiras de Sérgio Buarque de

\footnotetext{
${ }^{186}$ Cf. Código de Sacramentos: batizados (CSBa. 01) - 27/09/1688 a 08/02/1704. Arquivo Histórico da Cúria Diocesana de Taubaté.

${ }^{187}$ FARIA, Sheila de Castro. A Colônia em Movimento: fortuna e família no cotidiano colonial. Rio de Janeiro: Nova Fronteira, 1998. p. 194.
} 
Holanda, seja nas de Ilana Blaj, ou, mais recentemente, nas de Márcio Santos. ${ }^{188}$ Com extrema habilidade, Fernando Novais notou que "a intensa mobilidade aparece, portanto, como a mais geral característica da população no mundo colonial, em contraposição à relativa estabilidade característica do Velho Mundo." ${ }^{\prime 89}$ Enfim, tudo isso fazia parte da própria natureza do processo de colonização portuguesa na América.

A respeito do primeiro período salientado acima, sabe-se que as razões da ocupação efetiva do vale do Paraíba ainda geram controvérsias entre os estudiosos. São cotadas como as suas principais causas as notícias sobre a existência de minas de ouro, a situação geográfica, a caça de índios e a busca por terras. ${ }^{190}$ Recorda-se também das ordens oficiais da Condessa de Vimieiro para que devassassem a área. De qualquer forma, seria impossível dissociar em partes antagônicas os interesses oficiais e os interesses particulares, "ainda que no fundo, o motivo mesmo da empresa povoadora tenha sido o desejo de Portugal de, efetivamente, apossar-se da terra, há pontos em que cruzam e associam os interesses particulares com os oficiais." 191 Portanto, há que se reconhecer a coexistência de pressões internas e externas.

Seja a procura de metais e pedras preciosas, seja o desejo por terras e índios, ou mesmo como refúgio de conflitos internos, é possível que os primeiros anos de vida da vila tenham presenciado a inserção de ondas de migração. ${ }^{192}$ Elevada à categoria de vila em

${ }^{188}$ Cf. HOLANDA, Sérgio Buarque de. "Movimentos da população de São Paulo no século XVIII." Revista do Instituto de Estudos Brasileiros. São Paulo. Vol. I; BLAJ, Ilana. Op. cit.; SANTOS, Márcio. Bandeirantes Paulistas no Sertão do São Francisco: povoamento e expansão pecuária de 1688 a 1734. São Paulo: Editora da Universidade de São Paulo, 2009.

${ }^{189}$ NOVAIS, Fernando A. "Condições da Privacidade na Colônia." In: SOUZA, Laura de Mello e (org.). História da Vida Privada no Brasil: cotidiano e vida privada na América portuguesa. Vol. I. São Paulo: Companhia das Letras, 1997. p. 20

${ }^{190}$ Em termos de posição geográfica e processo de exploração colonial, vale citar o que diz Caio Prado Júnior. Para ele, o Tietê e, em menor escala, o Paraíba, foram rios utilizados "não só para as grandes expedições de reconhecimento e exploração do interior, as entradas e bandeiras, mas também, e isto é o principal, para o intercâmbio das populações que se estabelecem no planalto. E é para gozar das vantagens destes caminhos naturais e de fácil acesso que o povoamento procura no início de preferência, e quase exclusivamente, a margem dos rios." PRADO JÚNIOR, Caio. Evolução Política do Brasil e outros estudos. 3a. ed. São Paulo: Brasiliense, 1953. p.108.

${ }^{191}$ ABREU, Waldomiro Benedito de. Op. cit. p.104.

192 Além dos sonhos metalíferos e o desejo por terras, há quem acredite que as lutas entre as famílias dos Ramalhos e dos Pinheiros forçou a vinda destes para o vale do Paraíba, com grande contribuição na fundação de Taubaté. Cf. DANTAS, Luiz. "O Segredo dos Pinheiros". In: Revista do Instituto de Estudos Brasileiros. n ${ }^{\circ}$. 23, São Paulo: IEB/USP, 1981. 
1645, Taubaté constituiu-se como ponto de atração para aqueles que desejavam buscar novos ares.

Como vila recém-fundada, Taubaté e sua imensa área territorial serviram de atrativos para as pessoas que desejavam melhores condições de vida. Em toda a documentação consultada (inventários e testamentos) existente para o primeiro período (1640 a 1680), isto é, período inicial da instalação de pessoas na vila e de consolidação do processo de ocupação e exploração, foram encontradas 101 menções a posse de terras passíveis de identificação de origem. Dentre estas, 62 (61,4\%) eram reconhecidas por entrega via Sesmaria e Carta de Data, contra 39 (38,6\%) adquiridas através de compra. ${ }^{193}$ Isto é um indício de que a migração para a vila pode ter sido um atrativo visto que a oferta de terras era grande e que havia uma certa facilidade em adquirí-las sem que isso demandasse gastos iniciais extensos. John Monteiro é bastante coerente quanto a isso. Em sua pesquisa sobre a vila de São Paulo detectou que, a partir de 1640, os documentos acusam a falta de terras disponíveis para os colonos que estavam em plena expansão produtiva. Assim, a solução para este problema estava na concessão de sesmarias em áreas favoráveis, no caso, o vale do Paraíba. ${ }^{194}$ De fato, a falta de propriedades e de recursos contribuía para a itinerância da população, como bem ressaltou Glória Kok. ${ }^{195}$

Promessa de terras férteis, boatos sobre minas de ouro e uma fronteira com regiões que ofereciam mão-de-obra indígena, tudo isso pode ter contribuído para a migração ocorrida inicialmente. Da mesma forma que as terras, a abundância de mão-de-obra indígena disponível era uma realidade. Ainda sobre o mesmo período, encontrou-se o contingente de 1.868 índios distribuídos em 95 documentos, isto dá uma média de 19,6 para cada. A disponibilidade de toda essa força de trabalho agradava aqueles que pretendiam se instalar na vila e iniciar uma atividade produtiva. Em conjunto, essa situação, isto é, movimentação populacional, povoamento, tomada de territórios e posse de mão-de-obra escrava sintetiza, em partes, os aspectos do processo de colonização no Brasil. Enfim, resumidamente,

foi a múltipla abertura de novas áreas de fronteira agrícola, em várias regiões, entretanto, que imprimiu o ritmo da movimentação dos homens

${ }^{193}$ Essas informações foram extraídas de 95 documentos, entre inventários e testamentos, datados de 1649 a 1690. Todos estão tutelados pelo Arquivo Histórico Municipal de Taubaté.

${ }^{194}$ MONTEIRO, John Manuel. Op. cit. p. 107.

${ }^{195}$ KOK, Glória Porto. Op.cit. p. 31. 
durante todo o período colonial. Algumas se transformaram em ricas zonas de exportação ou com produções voltadas para um amplo mercado interno. Outras se caracterizaram por um povoamento mais esparso, com agricultura de alimentos para subsistência e pouca comercialização dos resultados do trabalho. Houve ainda as que, apesar de iniciado algum tipo de atividade, foram simplesmente abandonadas por vários séculos. ${ }^{196}$

Apesar das oportunidades oferecidas, dos grandes atrativos existentes, a instabilidade era o tom da vida cotidiana. As dificuldades inerentes à realidade do sertão ou de um povoado distante faziam-se presentes e influenciavam na prática do deslocamento das pessoas. Acredita-se que a preocupação imediata dos recém-chegados era, em grande medida, a moradia e a subsistência alimentar. Numa economia com bases essencialmente agrárias os frutos da produção estavam sujeitos às mudanças climáticas que determinavam os bons ou maus resultados. As incertezas ditavam os procedimentos em relação à ocupação do território. Muitas foram as famílias que se deslocaram para Taubaté. Outras prefiriram vir em partes. No inventário de Maria Delgado, por exemplo, datado de 1657, está registrado que os herdeiros, filhos da dita Maria, eram ainda moradores em São Paulo. ${ }^{197}$ Noutro caso, a precariedade da vila fez com que a viúva de João Azeredo Coutinho declarasse "ter seus filhos mandado a ensinar e a doutrinar na Ilha Grande onde gastou com eles." ${ }^{\prime 198}$ É de se supor que a incipiente produção agrária e a falta de instituições de ensino (fato comum a toda a colônia) tenham determinado a dispersão dos membros dessas famílias.

A ligação com os lugares de origem também pode ter gerado a circulação das pessoas. O instrumento jurídico da Procuração que firmava o poder que um indivíduo dava a outro para agir em seu nome, além de indicar um contato entre dois ou mais lugares denota a tentativa de evitar a locomoção do outorgante, mas, por outro lado, forçava o outorgado a tal. Foi o que aconteceu com Domingos do Prado Martins e Matheus Vaz da Silva como procuradores de Miguel Luis que receberam a missão, em 29 de agosto de 1678, de deixar Taubaté para ir "fazerem exame de sua sogra Domingas Pereira mulher de

\footnotetext{
${ }^{196}$ FARIA, Sheila de Castro. Op. cit. 26.

${ }^{197}$ Inventário de Maria Delgado (1657). Cx: 1649-1667. A.H.M.T.

${ }^{198}$ Inventário de João Azeredo Coutinho (1661). Cx: 1649-1667. A.H.M.T.
} 
seu sogro Manoel Dias Pereira mãe da dita sua mulher Luzia Pereira que faleceu na cidade do Rio de Janeiro."199

Estando de viagem de Taubaté para a cidade da Bahia, em 16 de fevereiro de 1679, Bernardo Bonfillio, natural de Gênova, registrou em cartório o desejo de outorgar a sua mulher, Maria da Sunssão, o Capitão Antonio de Faria Monteiro, Manoel Rodrigues Pinheiro, o Doutor Pedro Vaz Rocha e o licenciado Bartolomeu de Oliveira, todos moradores na dita cidade, como seus procuradores legais. ${ }^{200}$ Bernardo não só manteve laços afetivos entre ambos os lugares como também, ao que tudo indica, relações comerciais.

Francisco Martins Farel, morador em Taubaté, outorgou em 4 de agosto de 1676 a Paulo Correa Pinto, ao Capitão Gaspar Peres Dalmada e a João Monteiro Paiva, todos moradores na Ilha Grande, o direito de em seu nome e "com ele em pessoa" poder "cobrar e receber (...) e haverem a seu poder suas dívidas de dinheiro, fazendas, rendimentos, mercadorias, encomendas, carregações, escravos e seus procedidos e peças da terra e coisas de qualquer validade e sustância." ${ }^{201}$ Neste caso, ou Francisco Farel frequentava a Ilha Grande, ou seus procuradores a Taubaté, visto que ocorria de, em certos momentos, estarem juntos.

Estes exemplos mostram a contínua necessidade de locomoção dos colonos e, ao mesmo tempo, a tentativa de minimizá-la através das procurações.

Enfim, este primeiro período ficou marcado pela fundação e evolução da vila, e por isso mesmo, por uma instabilidade cotidiana. Ao longo dos anos, não obstante a consolidação do povoamento, da produção agrária e da dinâmica comercial, a circulação de indivíduos foi permanente, uma marca registrada cara a própria sociedade colonial, máxime a paulista.

Ao final do primeiro período, isto é, na década de 1680, é possível perceber, em termos econômicos e produtivos, uma certa regularidade e uma maior solidificação da vila. Seria natural, então, pensar num crescimento populacional. Passado o período inicial marcado pelas constantes instabilidades produtivas e pelos vai-e-vem das pessoas, a vida local se mostra através da documentação um pouco melhor. Maior número de fazendas

\footnotetext{
${ }^{199}$ Livro de Registros e Escrituras. Cx. 157 (1676-1700). Doc. Fragmento 1676/1679. f. 26 e 27.

${ }^{200}$ Livro de Registros e Escrituras. Cx. 157 (1676-1700). Doc. Fragmento 1676/1679. f. 36 e 37. Cf. também Inventário de Bernardo Bonfillio (1681). Cx: 1678-1689. A.H.M.T.

${ }^{201}$ Livro de Registros e Escrituras. Cx. 157 (1676-1700). Doc. Fragmento 1676/1679. f. 3 e 4.
} 
produzindo, maior oferta de alimentos, terras e mão-de-obra disponíveis, assim era Taubaté nesse momento.

A partir da década de 1690, e aqui já se está no segundo período estabelecido, o grande atrativo que pode ter influenciado na instalação de pessoas na vila, além dos pontos já salientados anteriormente, é o papel exercido pela vila como local de partida de muitas entradas sertanistas que demandavam os sertões além-Mantiqueira. Famílias inteiras chegavam à vila, "muitas houve que vieram esperançadas pelas minas de metais preciosos, sobre as quais as primeiras novas já corriam entre os habitantes da colônia (...)". ${ }^{202}$ Tal fato se torna claro quando Taubaté é reconhecida por exercer "o papel de centro irradiador da ocupação do Vale do Paraíba ao viabilizar o desbravamento dos Sertões de Taubaté ou Cataguases como era denominada a região das Gerais."

A vila ia se desenvolvendo muito em função das entradas sertanistas que dela partiam, mesmo porque se consagrava como uma “(...) etapa necessária a quem pretendia atirar-se à aventura das Minas Gerais." ${ }^{204}$ Havia empresas organizadas tanto pelos seus próprios habitantes como por diversos outros aventureiros que nesta povoação estacionavam antes de adentrarem o sertão. É possível então pensar que a dinâmica sócioeconômica encontrada em Taubaté teve grande impulso com a convivência entre uma realidade local, fechada em si, e as atividades sertanistas que, ao fim e ao cabo, lançavam o seu nome às mais distantes localidades. A última década do século XVII pode ter presenciado, então, um aumento de sua população e, ao certo, uma diversificação da sua economia. Existiram pessoas que se aproveitavam do papel exercido por Taubaté como entreposto sertanista para melhor investir seus recursos, ou seja, "criam-se no Vale muitas fazendas que passaram a fornecer gêneros alimentícios para as bandeiras vindas de São Paulo ou do litoral rumo ao Sabarabussu.",205

${ }^{202}$ GUISARD FILHO, Félix. Jacques Félix: achegas à História de Taubaté. São Paulo: Athena Editora, 1938. p. 22.

203 RANGEL, Armênio de Souza. Escravismo e Riqueza: formação da economia cafeeira no município de Taubaté (1765-1835). São Paulo: Tese de Doutorado - Faculdade de Economia Universidade de São Paulo, 1990. p. 47.

${ }^{204}$ SILVEIRA, Carlos da. "Cristovam Diniz de Anhaya, um paulista andejo." In: Revista do Arquivo Municipal de São Paulo. Ano I, abril de 1935. São Paulo, vol. XI. p. 35.

${ }^{205}$ MARTINS, Gilberto. Taubaté nos Seus Primeiros Tempos. Taubaté: Empresa Gráfica Editora Taubaté, 1973. p. 34. 
Em conjunto, os anos finais do século XVII e os iniciais XVIII, presenciaram algumas mudanças. Como se sabe, a descoberta das jazidas de ouro que teve lugar em meados de 1690, ou pelo menos a sua divulgação, gerou uma intensa movimentação de forças humanas e materiais no Brasil e, em Taubaté, não foi diferente. ${ }^{206} \mathrm{Com}$ participação direta no processo de desbravamento do sertão das Gerais e, conseqüentemente, no trabalho de prospecção, a população taubateana estava mais familiarizada com o "mundo interior" que diariamente se apresentava na vila sob formas variadas: ida e vinda de sertanistas, forasteiros, índios e caravanas, além das notícias, é claro.

Logo após a ocupação inicial das ricas terras mineiras através da formação de arraiais, muitas pessoas, sozinhas ou com toda a família, para lá se dirigiram. Muitos são os exemplos disso. Os Livros de Registros e Escrituras da vila estão recheados de informações que permitem a melhor visualização do fenômeno. Ainda no ano de 1693, em 23 de fevereiro, o Capitão Manoel Garcia Velho e sua Maria Fragosa registram a venda de "um lanço de casas de sobrado, de taipa de pilão, cobertas de telha de 15 braças de chãos para quintal", o qual foi comprador Francisco Luis Leme. O capitão Antonio de Barros Freire, como procurador do Capitão Manoel Garcia Velho, “fazia a venda do imóvel por ordem que lhe deu para fazer a dita venda quando para o sertão foi". ${ }^{207}$

Em 10 de maio de 1695, Antonio Vieira da Maia emprestou de Francisco Rodrigues Moreira vinte mil réis e lhe pagaria em ouro pois que "estava de caminho para as minas."208 Também o Capitão João da Veiga da Costa, devendo duzentas patacas a Manoel Rodrigues Cordeiro, em 9 de abril de 1696, prometeu "lhe pagar em ouro a volta do sertão das minas de Itaverava." 209 No mês de outubro de 1697, Gabriel de Góis da Costa declarou dever dezoito mil réis a Francisco Leite e por isso "se obrigava a dar-lhe a dita quantia em ouro em pó, a dez tostões o ouro, até a volta das Minas." ${ }^{210}$ João Delgado de Oliveira emprestou, em 20 de janeiro 1698, oitenta oitavas de ouro quintado de Domingos Cordeiro

\footnotetext{
${ }^{206}$ Como não podia ser diferente, "a maior parte da população que se dirigia para as Minas era constituída de paulistas, considerados selvagens e brutos, com intensa miscigenação com os índios." FURTADO, Júnia Ferreira. Homens de Negócio: a interiorização da metrópole e o comércio das minas setecentistas. 2a. ed. São Paulo: Hucitec, 2006. p. 219.

${ }^{207}$ Livro de Registros e Escrituras. Cx: 157 (1676-1700). Doc. 02. f. 6.

${ }^{208}$ Livro de Registros e Escrituras. Cx: 157 (1676-1700). Doc. 03. f. 21.

${ }^{209}$ Livro de Registros e Escrituras. Cx: 157 (1676-1700). Doc. 03. f. 45.

${ }^{210}$ Livro de Registros e Escrituras. Cx: 157 (1676-1700). Doc. 04. f. 4.
} 
comprometendo-se lhe pagar "a volta das minas de Itaverava que de presente segue."211 Outro que pegou dinheiro emprestado foi Francisco da Cunha Lobo, mais precisamente 36\$000 réis, e o credor foi Bento da Costa Preto, assim, firmaram acordo em 21 de novembro de 1698 na qual o devedor diz lhe devolver a quantia equivalente a 36 oitavas de ouro quintado "a volta das Minas desta viagem que de presente segue." ${ }^{212}$ Iguais a estes, existem muitos outros exemplos, o que mostra realmente a euforia da descoberta das minas refletida na população.

Os inventários e testamentos também revelam as atitudes frente às oportunidades do momento. O Capitão Sebastião Gil de Siqueira declarou em seu testamento que "João Pedroso me deve um rapaz a volta do sertão de onde anda agora." ${ }^{213}$ E no inventário do mesmo João Pedroso, falecido em 1691, consta que seu filho homônimo solicitou em 21 de março de 1703 ao juiz ordinário, o Capitão João Vaz Cardoso, o que lhe cabia e aos seus irmãos menores da herança de seu pai segundo a ordenação "pois se queria passar de morada com todos os bens para as minas." 214 Outro que parece ter frequentado as minas foi Diogo Teixeira da Cunha pois registrou em seu testamento, de 13 de novembro de 1698, que "trouxe na minha caixa cento e vinte oitavas de ouro em pó que são de meu irmão Antonio da Cunha", além de um cano de espingarda o qual é de João Machado morador em São Paulo e hoje está nas minas.” E mais, consta, agora em seu inventário, dever a Antonio da Cunha Abreu o terço da roça que o defunto plantou nas minas com os seus negros."215

Já que "as possibilidades de enriquecimento estavam, na mentalidade popular, abertas a todos (...)"216 , as áreas de fronteira pressionavam boa parte da sociedade a arriscar tudo que possuíam e ir tentar a vida longe do lugar de origem, atitude muito típica do mundo colonial. Migrantes e aventureiros, colonização e exploração são partes de um todo. Como se vê, então,

desde a última década seiscentista inúmeras famílias de Taubaté e outras localidades paulistas foram se passando para os povoados e sítios mineiros, de tal sorte que em paralelo às atividades de pesquisa e

\footnotetext{
${ }^{211}$ Livro de Registros e Escrituras. Cx: 157 (1676-1700). Doc. 04. f. 19.

${ }^{212}$ Livro de Registros e Escrituras. Cx: 157 (1676-1700). Doc. 05. f. 17 .

${ }^{213}$ Inventário do Capitão Salvador Gil de Siqueira (1691). Cx: 1691-1699. A.H.M.T. O testamento encontra-se anexado ao documento.

${ }^{214}$ Inventário de João Pedroso (1691). Cx: 1691-1699. A.H.M.T.

215 Inventário de Diogo Teixeira da Cunha (1699). Cx: 1691-1699. A.H.M.T. O testamento encontra-se anexado ao documento.
}

${ }^{216}$ FARIA, Sheila de Castro. Op. cit. p. 113. 
exploração das minas se ia desenvolvendo, continuamente, um processo de colonização. ${ }^{217}$

Ao que tudo indica, se num primeiro momento pode ter havido uma maior circulação populacional devido às oportunidades oferecidas com o desenvolvimento das minas, por outro lado o movimento inverso não deixa de ter ocorrido nas mesmas proporções, através do retorno de boa parte delas. Isso não quer dizer que a movimentação das pessoas teria se estagnado, ao contrário, ainda continuou em grande quantidade. Seja ainda visando a exploração mineira, seja com objetivos comerciais (agora com muito vigor), muitos homens continuaram partindo de Taubaté para as Gerais. Na verdade, é quase que impossível distinguir em períodos tais práticas, isto é, não dá para se estabelecer um momento da "ida" e outro da "volta", visto que elas ocorrem simultameamente. Tanto a década de 1690 como as duas primeiras do século seguinte presenciam a ida e vinda de pessoas das minas. Daí a escolha desses anos como um segundo período para análise.

As viagens para as minas, então, fizeram parte do cotidiano de Taubaté. Muitos foram, muitos voltaram. A grande inserção de ouro trazido por esses aventureiros serve de prova para tal prática. E mais, a disponibilização de recursos financeiros - sendo o ouro como responsável por isso - possibilitou a negociação de empréstimos envolvendo mais viagens para as minas.

Lançando sua sorte, Antonio Dias de Oliveira, provalmente o famoso sertanista que descobriu o cobiçado metal precioso em Ouro Preto ${ }^{218}$, adquiriu em 16 de abril de 1700 um empréstimo no valor de 100 oitavas de ouro em pó, firmando acordo com o seu credor de que "lhas daria a volta das minas desta viagem que de presente faz."219 Outro que também seguiu o mesmo caminho foi o Capitão Manoel Homem de Azeredo que, em data de 23 de novembro de 1702, contraiu dívida de 200 oitavas de ouro em pó a fím de levar consigo na

${ }^{217}$ ORTIZ, José Bernardo. São Francisco das Chagas de Taubaté. Tomo II. Taubaté: Prefeitura Municipal de Taubaté, 1996. p. 303.

218 "Sertanista de São Paulo, nascido em Taubaté e que foi o descobridor de ouro no Ouro Preto, em 1698. De 1700 a 1701 abandonou as suas lavra nesse local e foi minerar no Piracicaba, onde erigiu em 1706 um arraial conhecido por Antonio Dias Abaixo. Teve patente de Guarda-Mor dessa região em 11 de janeiro de 1711 e nesse documento se faz referência aos muitos serviços que prestou como sertanista." FRANCO, Francisco de Assis Carvalho. Op. cit. p. 268.

${ }^{219}$ Livro de Registros e Escrituras. Cx: 158 (1700-1711). Doc. 01. f. 13. 
viagem que faz as Minas. ${ }^{220}$ Foram muitos os casos iguais as estes. De fato, o trânsito de pessoas que fazeram o trajeto entre Taubaté e as minas foi intenso.

Ao retorno, de igual maneira, estabelecia-se uma "escritura de destrato" que era o registro da quitação de dívida. Foi o que fez o Capitão Gaspar Vaz da Cunha "à volta das minas", em 21 de setembro de 1701, entregou ao Capitão Bento da Costa Preto a quantia de 85 oitavas de ouro em pó de que devia. ${ }^{221}$ Outra consequência que muitas vezes ocorria com as pessoas que retornavam das minas era a manutenção de relações pessoais e de negócios. Dizem os herdeiros de Jerônimo da Veiga Correa, inventariado em 1716, que era a dever doze mil réis "Antonio Luiz morador desta vila que de presente se acha nas minas."222 Já no testamento de Bartolomeu Bueno de Mendonça, feito em 1704, que "tudo o que me deve meu cunhado José Martins Gago [são] 14 oitavas de ouro procedidas de ferramentas que lhe deixei nas minas as quais cobrarão meus herdeiros."223

Poderia também não ser completamente feliz a volta a Taubaté. Foi o que aconteceu com Francisco Borges que, em 1703, declarou que "sua esposa falecera repentinamente há um ano pouco mais ou menos estando ele nas minas."224

Muitos acabaram não voltando, ou porque preferiram ficar ou porque morreram. No inventário do Capitão Manoel da Costa Cabral, que data de 15 de junho de 1711, existe um registro de que um de seus herdeiros, Francisco de Arruda, está ausente nas minas e, sendolhe enviadas duas precatórias não houve resposta. ${ }^{225} \mathrm{~A}$ interação de Francisco com as minas parece ter sido tão intensa que acabou por cortar seus laços parentais, ou pelo menos, o isolou dos contatos vindos da vila de origem. Fato comum era a notícia da morte de algum aventureiro. Com certo atraso, coisa natural para a época, Assença da Mota diz, em 23 de novembro de 1703, que "seu marido falecera nas minas havera ano e meio."226 Já o Capitão Pedro Teixeira da Cunha morreu, em 1704, no Rio das Mortes "distrito de Mato Dentro termo da Vila Nova da Rainha."227 Outro que não voltou foi o Capitão João Cabral da Silva que "faleceu nas minas de Ouro Preto", em 1702, e após sua morte foi entregue

\footnotetext{
${ }^{220}$ Livro de Registros e Escrituras. Cx: 158 (1700-1711). Doc. 01. f. 98-99.

${ }^{221}$ Livro de Registros e Escrituras. Cx: 158 (1700-1711). Doc. 01. f. 101 e 102.

${ }^{222}$ Inventário de Jerônimo da Veiga Correa (1716). Cx: 1716-1719. A.H.M.T.

${ }^{223}$ Testamento de Bartolomeu Bueno de Mendonça (1704). Cx: 1704-1717. A.H.M.T.

${ }^{224}$ Inventário de Ana Vaz Bicuda (1703). Cx: 1700-1703. A.H.M.T.

${ }^{225}$ Inventário do Capitão Manoel da Costa Cabral (1711). Cx: 1709-1715. A.H.M.T.

${ }^{226}$ Inventário de Domingos Soares (1703). Cx: 1700-1703. A.H.M.T.

${ }^{227}$ Inventário do Capitão Pedro Teixeira da Cunha (1704). Cx: 1704-1717. A.H.M.T.
} 
aos herdeiros, moradores em Taubaté, 703 oitavas de ouro em pó que pertenciam ao defunto. $^{228}$

Enfim, algumas pessoas tiveram mais sorte que outras. Enquanto que uma parcela delas pôde retornar com uma certa quantidade de riqueza - basicamente ouro - , existiram aquelas que voltaram na mesma condição que foram, senão mais pobres e debilitados. Aos que fizeram parte do primeiro grupo, coube a injeção de riquezas na vila, aumentando a circulação de bens e, principalmente, crédito. Há, com isso, uma diversificação da economia, inclusive, com a inserção de escravos africanos que, aos poucos passaram a competir em números com os índios que, até então, compunham a base da mão-de-obra local.

Passa-se agora a discorrer brevemente sobre a composição social de Taubaté.

O objetivo é, aqui, unicamente o de expor a proporção social existente na população taubateana equivalente a três tipos de indivíduos - livres, índios e negros - e não discutir questões etnográficas. Mas também não se pode deixar de fazer algumas considerações sobre as características encontradas na sociedade formada desde muito cedo nas capitanias do sul (São Vicente e Itanhaém).

A colonização da região sul do Brasil e as suas especificidades sociais, econômicas e políticas foi, e ainda é, forte atrativo para pesquisadores. Em especial, as relações até certo ponto íntimas entre o elemento branco e os nativos estão entre os temas mais estudados, mesmo porque é impossível dissociar o indígena e sua cultura do curso tomado pela história paulista. Por muito tempo, as teorias de raça e determinismo geográfico eram as fórmulas para se pensar o paulista, ou melhor, o seu formato oriundo da miscigenação, o "mameluco". Autores da primeira década do século XX defendiam a existência de uma raça diferenciada, capaz de sobreviver às dificuldades do meio, detentora de um espírito altivo, democrático, justo, solidário e aventureiro. Literalmente uma "raça de gigantes". 229

\footnotetext{
${ }^{228}$ Inventário do Capitão João Cabral da Silva (1702). Cx: 1700-1703. A.H.M.T.

229 Encabeçava esta tendência historiográfica Alfredo Ellis Júnior que, tomando emprestada a expressão "raça de gigantes" cunhado por Sant-Hilaire, publicou vários textos que defendiam a superioridade dos paulistas frente ao resto do Brasil. Cf. SAINT-HILAIRE, Augustin. Viagem a Província de São Paulo. São Paulo: Itatiaia, 1976. ELLIS JÚNIOR, Alfredo. Raça de Gigantes: a civilização no planalto paulista. São Paulo: Editora Helios Limitada, 1926.
} 
Diferentemente das teses vigentes, Sérgio Buarque de Holanda se dedicou à análise não da miscigenação racial, e sim cultural, que para ele era o ponto chave para se entender os hábitos de uma determinada sociedade. Diz Holanda:

para a análise histórica das influências que podem transformar os modos de vida de uma sociedade é preciso nunca perder de vista a presença, no interior do corpo social, de fatores que ajudam a admitir ou a rejeitar a intrusão de hábitos, condutas, técnicas e instituições estranhos à sua herança de cultura. ${ }^{230}$

Enfim, se houve o hibridismo racial e cultural, isso quer dizer que existiam condições favoráveis para tal, uma aceitação conjunta, não sem algum esforço e resistência, às vezes violenta, mas que de uma forma ou de outra forjou a realidade sócio-cultural paulista, isto é, "as relações interétnicas, assim, faziam parte do cotidiano dos moradores da capitania de São Paulo."231

Questões culturais à parte, cabe observar como era composta a população de Taubaté durante o período estudado. Com o quadro abaixo pretende-se ilustrar melhor as divisões sociais, divisões estas muito comuns em toda a história de São Paulo.

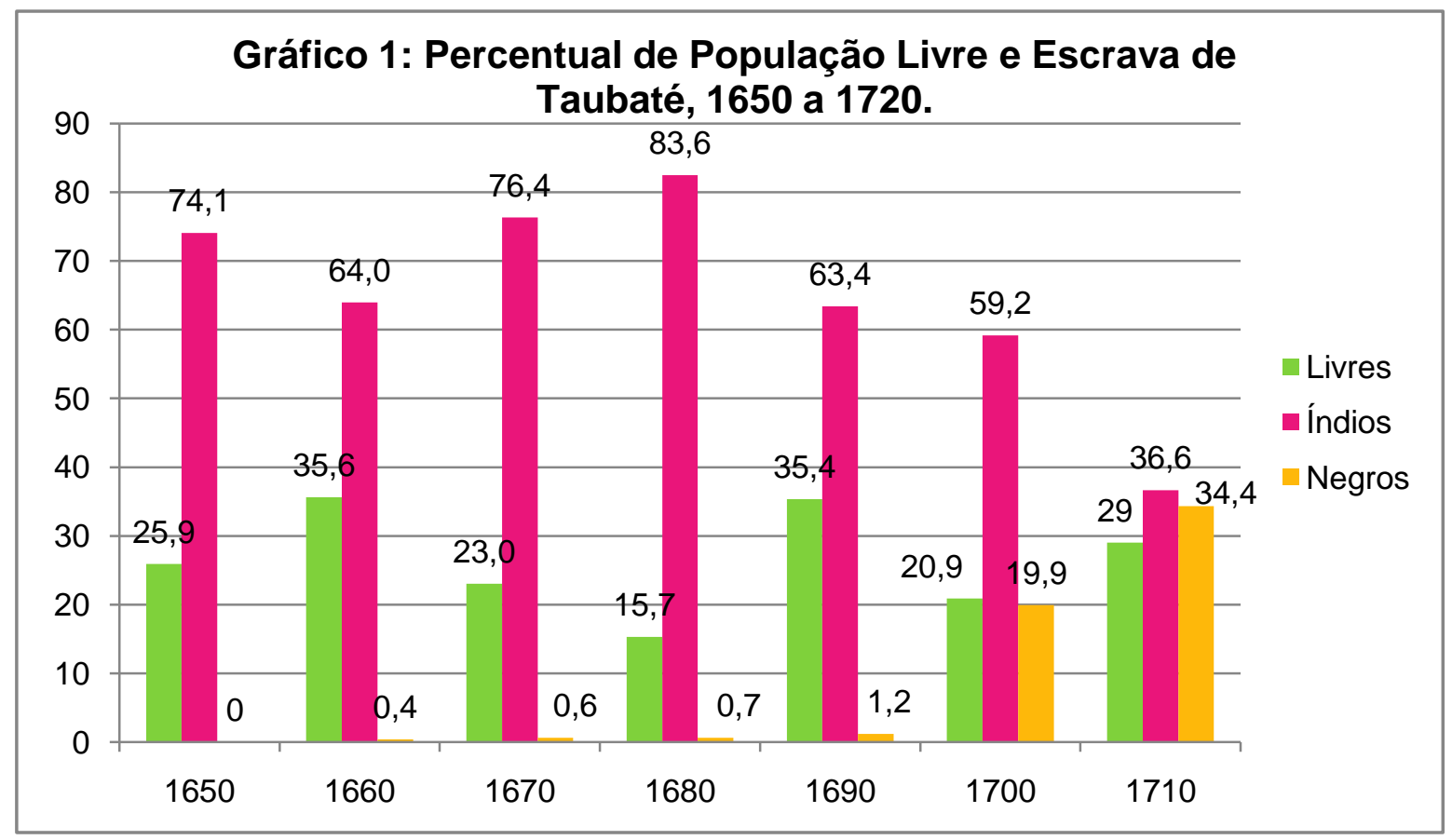

Fonte: Inventários (1649 a 1720). Arquivo Histórico Municipal de Taubaté.

${ }^{230}$ HOLANDA, Sérgio Buarque de. Caminhos e Fronteiras. $3^{\mathrm{a}}$. ed. São Paulo: Companhia das Letras, 1994. p. 55.

${ }^{231}$ KOK, Glória Porto. O Sertão Itinerante: expedições da capitania de São Paulo no século XVIII. São Paulo: Hucitec: Fapesp, 2004. p. 64. 
De maneira geral, o que se vê é um quadro social tipicamente colonial, sobretudo paulista. As relações existentes são orientadas pelo regime senhorial-escravista. Definitivamente, era uma vila assentada no trabalho compulsório, e dele vivia a economia local. Independentemente da atividade exercida, seja agrária, seja comercial, seja sertanista, lá estava o índio escravizado, corroborando a afirmação de que “(...) o verdadeiro ouro dos paulistas eram os índios que eles escravizavam."232

Durante todo o período considerado há o predomínio do elemento indígena, variando entre a máxima parcela de $83,6 \%$ a mínima de 36,6\%. Tal variação está diretamente ligada às situações como: inserções de novas levas de índios recémescravizados, mortalidade, natalidade, às próprias atividades sertanistas que se utilizavam de muitos deles como guias e ajudantes e, por fim, às oscilações dos outros elementos sociais, isso ocorre porque é um gráfico de percentual, ou seja, se uma coluna cresce conseqüentemente a outra declina.

Apenas a título de comparação, também vista como maneira de associar diferentes vilas a uma mesma característica, a alta porcentagem de população indígena também pode ser verificada em São Paulo. Para meados do século XVII, Sérgio Buarque de Holanda estima que tal grupo social comporte $83 \%$ do total da população, caso muito parecido com o que se vê em Taubaté na década de $1680 .^{233}$

A presença maciça de índios na vila é fruto das atividades de preamento organizadas pelos próprios habitantes dela. Ao que parece, a vida econômica girava em torno deles. A produção agrária dependia desta mão-de-obra e muitos dos fazendeiros também participavam das caçadas a fim de aumentar seu plantel de escravos, expandindo assim sua

${ }^{232}$ SOUZA, Laura de Mello e; BICALHO, Maria Fernanda Baptista. 1680-1720: o império deste mundo. São Paulo: Companhia das Letras, 2000. p. 22. Todos os índios computados foram considerados escravos visto que foram arrolados no inventário como posse da família, onde pôde ser constatado o caráter intrínsico do seu valor monetário seja ele medido através do indivíduo em si ou por meio de seus serviços, já que a escravização indígena implicava problemas jurídico-legais. Neste caso, existiam diversas as maneiras de se burlar a condição cativa dos indígenas, uma delas era registrar a posse como sendo apenas pela "administração", isto é, não percentiam ao senhor mas estavam sob sua tutela, o que na verdade não mudava a condição prática da escravidão. Para análise mais aprofundada conferir a importante obra de John Monteiro. Negros da Terra: índios e bandeirantes nas origens de São Paulo. São Paulo: Companhia das Letras, 1994. Destaque para o capítulo "A Administração Particular".

${ }^{233}$ Cf. HOLANDA, Sérgio Buarque de. "Movimentos da população de São Paulo no século XVIII". Revista do Instituto de Estudos Brasileiros. São Paulo, v.1, 1966. p. 55-111. 
produção. Por muito tempo pensou-se que os paulistas caçavam índios para vender aos engenhos de cana da região nordeste, pois era lá que estava assentada a máquina de exploração colonial. ${ }^{234}$ Estudos atuais apontam para outro caminho, trazendo à tona a dinâmica econômica existente em São Paulo e suas redondezas. ${ }^{235}$ Servia-se a sociedade dos frutos de seu próprio esforço sertanista.

Como a posse de índios escravos dependia dos próprios habitantes, e o seu custo era relativamente barato, o seu alto percentual se manteve até a década de 1700. A década seguinte, todavia, mostra uma situação interessante, pois quase que se igualam a porcentagem de livres, índios e negros.

A inserção de negros africanos era mais dificultosa não só em termos geográficos, já que para chegarem a Taubaté o caminho era demasiadamente longo, mas também econômico pois custavam inicialmente quase o dobro do valor dos índios. ${ }^{236}$ Tal barreira é representada pelo gráfico. Os africanos só começaram a ter presença significante a partir da década de 1690, saltando bruscamente nas duas décadas seguintes, chegando a atingir $34,4 \%$ da população. Essas informações merecem maior atenção visto que vão de encontro a certas posições historiográficas sobre o assunto. Por muito tempo acreditou-se que "em São Paulo, dos quinhentos, dos seiscentos e mesmo da primeira metade dos setencentos o negro era ausente e mesmo quase desconhecido, só existindo em casos esporádicos."237 Essa situação teria ocorrido, segundo Suely Robles Reis de Queirós, pelo fato de São Paulo viver somente de uma economia de subsistência, isto é, sem maiores demandas por mão-deobra, ou melhor, nada acima do que os índios cativados pudessem suprir. Somente após a descoberta de ouro é que houve uma procura por negros africanos, porém estes eram geralmente destinados às Gerais juntamente com as grandes levas de paulistas que para lá se moveram. Assim, a presença de africanos em São Paulo ocorreu porque muitos deles desembarcavam nos portos paulistas rumo às minas e, "inevitavelmente alguns seriam aproveitados pelos habitantes locais, mas a quantidade tendia a ser muito pouco

${ }^{234}$ Cf. ZEMELLA, Mafalda P. O Abastecimento da Capitania das Minas Gerais no século XVIII. $2^{\text {a }}$. Ed. São Paulo: Hucitec: Editora da USP, 1990.

${ }^{235}$ Cf. MONTEIRO, John Manuel. Op. cit.

${ }^{236} \mathrm{Na}$ década de 1660, data em que foi encontrado o primeiro negro em Taubaté, os valores eram os seguintes: um índio adulto estava avaliado em torno de $25 \$ 000$, enquanto que o negro valia $45 \$ 000$.

${ }^{237}$ ELLIS JÚNIOR, Alfredo. Raça de Gigantes: a civilização no planalto paulista. São Paulo: Editora Helios Limitada, 1926. p. 89. 
expressiva." 238 Ainda para esta autora, a insignificante presença de africanos em São Paulo também teria sua causa na decadência econômica vivida após o despovoamento da região. ${ }^{239}$ Dessa forma,

o surto minerador não age como fator de fixação do elemento negro em São Paulo. Ao contrário, exerce ação negativa por várias razões: também impele grandes levas de paulistas para fora de sua Capitania, agindo como fator de despovoamento. Se a despovoava de homens brancos que seriam o elemento dominador do negro escravo, não poderia consequentemente povoá-la de negros. Além disso, a diminuição da densidade demográfica da Capitania levaria a uma queda da produtividade agrícola bem como ao declínio das demais atividades. ${ }^{240}$

Suely finaliza dizendo que o negro africano só faria parte da sociedade paulista em fins do século XVIII mas, principalmente, no XIX que foi quando surgiu uma economia de maior produção assentada na plantação de cana-de-açúcar e café. ${ }^{241}$

De fato, para os séculos XVI e XVII a proporção de negros em relação ao resto da população deveria ser muito pequena. No entanto, a situação muda já na virada para o século XVIII. O gráfico anterior mostrou que foi bastante significativa a inserção de negros africanos em Taubaté. Essa ascensão pode ser explicada: coincide com as descobertas metalíferas nas Minas Gerais, o que denota uma maior liquidez de riquezas nas mãos dos habitantes da vila que por sua vez tinham a possibilidade financeira de adquirir tais negros. Além dos recursos disponíveis, surge também a oportunidade de aumentar a produção agrária a fim de atender as necessidades dos novos povoados que iam se formando nas Gerais. Como muitos índios foram levados para trabalharem nas lavras, houve maior demanda por trabalhadores braçais.

$\mathrm{O}$ interesse dos habitantes taubateanos nos escravos africanos era tanto que muitos aventureiros que passavam pela vila antes de seguir rumo às minas conseguiram adquirir empréstimos dando por garantia seus cativos. Em 20 de setembro de 1699, Pascoal da Silva Guimarães "morador em a cidade do Rio de Janeiro e ora estante nesta vila", contraiu

238 QUEIRÓS, Suely Robles Reis de. Escravidão Negra em São Paulo: um estudo das tensões provocadas pelo escravismo no século XIX. Rio de Janeiro: José Olympio, 1977. p. 18.

${ }^{239}$ A tese do despovoamento de São Paulo foi, coerentemente, contextada por Maria Luíza Marcílio que, ao invés de um declínio, identificou um crescimento de $400 \%$ em sua população. Cf. MARCÍlLIO, Maria Luiza. Crescimento demográfico e evolução agrária paulista: 1700-1836. Tese (Livre Docência) - FFLCH: USP: São Paulo, 1974. Será discutido mais adiante o tema da economia paulista e os novos pontos de vista que contrariam esta suposta decadência.

${ }^{240}$ QUEIRÓS, Suely Robles Reis de. Op. cit. p. 16.

${ }^{241}$ Idem, Ibidem. p. 19 e seguintes. 
dívida com Domingos Rodrigues do Prado, "morador nela." A quantia acertada foi de $382 \$ 500$ mil réis e "confessa haver recebido esse dinheiro em ouro quintado que tomava a ganhos pelo espaço de um ano a 8\%", e caso não pague a dívida "disse obrigava sua pessoa e bens móvies e de raiz havidos e por haver futuros e contingentes e em especial dois negros do gentio da Guiné ambos por nome Francisco e outros dois do dito gentio, ambos por nome Alexandre." ${ }^{242}$ Noutra escritura há o mesmo acordo. O Capitão Sebastião de Siqueira Gil, morador em Taubaté, emprestou, em 11 de janeiro de 1700, 780\$000 mil réis em ouro quintado ao Capitão Fernando Faleiro Homem "morador no Rio de Janeiro e ora estante nesta vila", tendo como garantia quatro negros gentios da Guiné que o devedor trazia em sua companhia. $^{243}$

Se por um lado a procura por negros africanos foi grande, por outro a intensa circulação de ouro pela vila chamou a atenção de negociadores. São muitas as transações envolvendo ouro e escravos. João Ribeiro da Rosa comprou de João Correa da Silva, morador no Rio de Janeiro, uma negra do gentio da Guiné por nome Isabel pelo preço de 200 oitavas de ouro em pó, comprometendo-se a pagar-lhe "sem a isso pôr dúvida ou embargo", o que foi acertado em 8 de outubro de $1700 .^{244}$ Outro negócio feito foi envolvendo André Leme da Silva e Francisco Rodrigues da Silva. O primeiro comprou deste dois negros do gentio da Guiné pelo valor de $500 \$ 000$ mil réis, porém restava pagar 416\$950. Assim, fizeram uma escritura datada de 16 de dezembro de 1700 em que o devedor promete quitar tal dívida até o mês de abril de $1701 .^{245}$ Outro caso interessantíssimo que comprova a inserção dos negros africanos em Taubaté diz respeito a uma escritura de dívidas que "fazem o Sargento-mor Francisco Félix Correa, João de Toledo Piza, Domingos de Quevedos Cabral, Lourenço de Siqueira Machado e Manoel Ferreira de Castilho todos moradores nesta vila a João Dias morador na cidade da Bahia e ora estante nesta vila de Taubaté." ${ }^{246}$ Firmaram em 10 de janeiro de 1701 a compra de 14 escravos do gentio da Guiné "de vários senhores moradores na dita cidade da Bahia e seu Recôncavo" pelo valor de 1.599 oitavas de ouro quintados e obrigavam-se a "pagar tudo no mês de dezembro próximo desta dita era em vila de Parati por suas contas e riscos deles

\footnotetext{
${ }^{242}$ Livro de Registros e Escrituras Cx: 157 (1676-1700). Doc. 05. f. 51.

${ }^{243}$ Livro de Registros e Escrituras Cx: 157 (1676-1700). Doc. 05. f. 69.

${ }^{244}$ Livro de Registros e Escrituras Cx: 158 (1700-1711). Doc. 01. f. 30.

${ }^{245}$ Livro de Registros e Escrituras Cx: 158 (1700-1711). Doc. 01. f. 33.

${ }^{246}$ Livro de Registros e Escrituras Cx: 158 (1700-1711). Doc. 01. f. 36 e 37.
} 
ditos. ${ }^{247}$ E tiveram o cuidado de registrar que "cada um de per si fazia esta obrigação sobre o abono de suas pessoas e bens fiando-se uns aos outros e um por todos e cada um por si." Pode-se citar muitos outros casos semelhantes a estes acima, porém não há espaço para tanto. Enfim, demanda, oferta e recursos financeiros disponíveis foi a combinação perfeita para a inserção dos negros em Taubaté.

Já com relação à parcela livre da sociedade, nada de novo se percebe. Muito comum ao retrato da colônia como um todo. Os livres sempre se mantiveram por volta de $1 / 3$ da população, sofrendo algumas variações, a mínima registrada em 15,3\% e a máxima em 35,6\%. Preferiu-se não entrar em detalhes quanto à caracterização desse grupo. Havia brancos, índios forros e a massa de mamelucos. A documentação pouco fala quanto a isso. Poucas referências são encontradas, algumas indicam filhos bastardos, outros mencionam índios livres, mas nada que se possa quantificar.

A presença dos chamados bastardos não significa necessariamente a constituição de ligações parentais, já que se percebe também neste termo a alusão aos mamelucos. Porém, em muitos casos, a atenção dada pelo testador com um ou outro bastardo denuncia uma afetividade implícita, atenção esta que pode indicar uma ligação parental. Bartolomeu da Cunha Gago, homem de grandes posses, incluindo 256 índios, escreveu em seu testamento datado de 16 de janeiro de 1685: "declaro que tenho mais três bastardos em minha casa, a saber, por seus nomes Henrique, Vitorino outra rapariga Joana os quais deixo forros e peço a minha mulher que the dê o tratamento e os ampare como filhos." 248 Apesar de não assumir diretamente a paternidade, pede para sua mulher os criar "como filhos", talvez dele também. Outro que declarou ter um bastardo foi Bartolomeu Bueno de Mendonça em seu testamento feito no ano de $1704 .^{249}$ Ao testar em 28 de julho de 1716, o Capitão Domingos Rodrigues do Prado, o moço, confessou que "tenho um bastardo por nome Manoel" e

\footnotetext{
${ }^{247}$ Vale citar aqui a descrição das "peças escravas", seus donos e seus valores: 1 negro da Nação Arda, de Antonio Lopes Terrão - 128 oitavas; 1 negro Antonio e outro Felipe, de João de Andrade Ozória embarcados por Manoel Correa Lima - 128 oitavas cada um; 1 negro Gregório, do Sargento-mor Cristóvão Coelho Vilas Boas - 105 oitavas; 1 negro Gaspar, de Antonio Maciel Teixeira - 90 oitavas; 2 moleques ambos por nome Manoel, de Antonio de Sousa - 85 oitavas; 2 negros por nomes Domingos e Manoel, do Padre Manoel Ferreira - 105 oitavas cada um; e 5 negros por nomes Francisco, Paulo, Vicente, Garcia, Antonio, que disse eram de sua conta e de seu irmão José Dias - 128 oitavas cada um.

${ }^{248}$ Testamento de Bartolomeu da Cunha Gago (1685). Cx: 1678-1689. A.H.M.T.

${ }^{249}$ Testamento de Bartolomeu Bueno de Mendonça (1704). Cx: 1704-1717. A.H.M.T.
} 
ordenou aos herdeiros que ele "fica dispendido de qualquer servidão."250 A escravização de filhos bastardos era uma realidade e essa prática pode ter pesado na consciência de Francisco Coelho de Abreu. Este declarou em 29 de agosto de 1697 que "vendi em Paraty um rapaz mameluco por nome João a André de Pontes o qual peço pelo amor de Deus a minha mulher e filhos o tornem a resgatar por serviço de Deus e desencargo de minha consciência."251 Não há provas de que João era seu filho, porém a preocupação e, principalmente, o medo que demonstrou servem de indícios de algum tipo de ligação parental ou, pelo menos, de responsabilidade. ${ }^{252}$

Algumas pessoas carregavam em seus nomes o peso da discriminação. No inventário do capitão Salvador Gil de Siqueira, este diz que um tal "Domingos Gil, o Bastardo" lhe devia $1 \$ 280 .^{253}$

Ter filhos ilegítimos poderia causar problemas. Aproveitando-se disso, algumas pessoas chegavam até a lucrar com isso. Salvador de Morais devia a Antonio Antunes Barbosa cerca de quatro mil réis correspondentes à "criação de um filho seu bastardo." 254 Já no inventário de Ana Vaz Cardozo, iniciado em 22 de julho de 1692, há uma declaração do conhecido sertanista Salvador Fernandes Furtado em que diz ser devedor "neste inventário

\footnotetext{
${ }^{250}$ Inventário do Capitão Domingos Rodriges do Prado, o moço (1717). Cx: 1716-1719. A.H.M.T. $\mathrm{O}$ testamento encontra-se anexado ao documento.

${ }^{251}$ Inventário de Francisco Coelho de Abreu (1697). Cx: 1691-1699. A.H.M.T. O testamento encontra-se anexado ao documento.

${ }^{252}$ Vale lembrar que a crença no "julgamento" pós-morte fazia com que as pessoas exercitassem uma rápida leitura de suas vidas e registrassem nos testamentos todas as ações cometidas que pudessem as prejudicar. Assim, a "importância dada à confissão denota a ação eclesiástica no sentido da culpabilização e, por seguinte, no convencimento do fiel acerca da punição dada aos que não se mostrassem arrependidos e não seguissem as diretrizes eclesiásticas. Essa punição auricular e na penitência, a Igreja dava um passo decisivo na direção da formulação da Pedagogia do Medo, que se utilizaria da morte, do julgamento divino e da possibilidade de condenação transitória ou eterna como elementos de pressão sobre a consciência e o comportamento dos fiéis." RODRIGUES, Cláudia. Nas Fronteiras do Além: a secularização da morte no Rio de Janeiro (séculos XVIII e XIX). Rio de Janeiro: Arquivo Nacional, 2005. p. 46-47. Sobre as atitudes dos homens perante a morte no Brasil Cf. REIS, João José Reis. A Morte é uma Festa: ritos fúnebres e revolta popular no Brasil do século XIX. São Paulo: Companhia das Letras, 1991.

${ }^{253}$ Inventário do Capitão Salvador Gil de Siqueira (1691). Cx: 1691-1699. Arquivo Histórico Municipal de Taubaté. Ao longo do tempo, “(...) o termo mameluca foi sendo paulatinamente substituído por bastarda, termo que juntou o significado de ilegítima com a conotação étnica de mestiça." SILVA, Maria Beatriz Nizza da (org.). História de São Paulo Colonial. São Paulo: Editora UNESP, 2009. p.73.

${ }^{254}$ Inventário de Antonio Antunes Barbosa (1681). Cx: 1678-1689. A.H.M.T.
} 
$4 \$ 500$ e 4\$000 mil réis procedidos da criação de sua bastarda." ${ }^{255}$ Outros se aproveitaram para usufruir da força de trabalho destas pessoas. No arrolamento dos bens de Antonio de Siqueira de Escobar, os herdeiros dizem que os gentios da terra João e Guiomar eram "bastardos criados em casa filhos de Verônica cujos pais se não sabem aparecendo pessoa a quem pertençam pagando a criação lhos entregarão."256

Sabe-se que a miscigenação era muito comum, principalmente entre brancos e índios, já entre negros e índios ou negros e brancos, era coisa muito rara, pelo menos até o fím do século XVII. ${ }^{257}$ Como se viu, as décadas de 1700 e 1710 assistem ao crescimento da população negra e, nesse contexto, os contatos sexuais poderiam ser consumados, mas esse assunto não cabe discutir profundamente aqui.

Ao longo destas páginas procurou-se mostrar as situações que devem ter proporcionado mudanças na população de Taubaté ao longo do tempo, tanto em quantidade como em diversidade. Tais quadros estavam intimamente ligados às conjunturas sócioeconômicas. Migração, produção, riqueza, tudo isso influenciava na composição social da vila. Estudar as principais atividades econômicas exercidas em Taubaté pode ajudar a entender o rumo tomado pela vila no curso da sua história.

\subsection{Economia Local e Distribuição da Riqueza}

Em geral, é escassa a historiografia sobre o vale do Paraíba e muito mais sobre a vila de Taubaté no seu período colonial. Completamente inverso é este quadro quando os temas estudados estão inseridos no século XIX como, por exemplo, a cafeicultura e a emancipação dos escravos. Talvez pela maior quantidade de documentação e pela melhor facilidade na sua leitura, tal período histórico está entre a preferência dos especialistas.

Além de serem poucas, as obras que tratam de Taubaté nos seus primeiros tempos ou são antigas ou não se enquadram nos moldes de um trabalho cientificamente orientado. Problemas como a não citação de fontes, a falta de pesquisa documental, o velho conhecido

\footnotetext{
${ }^{255}$ Inventário de Ana Vaz Cardozo (1692). Cx: 1691-1699. A.H.M.T.

${ }^{256}$ Inventário de Antonio de Siqueira de Escobar (1694). Cx: 1691-1699. A.H.M.T.

${ }^{257}$ Sobre a miscigenação existente no último quartel do século XVII, Charles Boxer diz que "na região de São Paulo os mamelucos mostravam-se mais numerosos, e pessoas com mistura de sangue negro, bem como brancos puros, eram literalmente raras." BOXER, Charles R. A Idade de Ouro do Brasil: dores de crescimento de uma sociedade colonial. $3^{\mathrm{a}}$. Ed. Rio de Janeiro: Nova Fronteira, 2000. p. 46.
} 
“bairrismo", a exaltação de personagens históricos, enfim, são obras que merecem revisão. Reconhece-se a importância delas como pioneiras que por muito tempo foram as únicas referências sobre a história de Taubaté. Se hoje é possível propor novas interpretações é porque o conhecimento atual foi fruto do processo iniciado muitas décadas atrás.

A economia, em especial, é o aspecto que foi analisado com maior intensidade. Porém, o que se percebe é que existe uma "tradição" que perpassa anos e mais anos, mantendo-se até mesmo no conhecimento popular através, principalmente, do ensino escolar, velhas definições comuns à sociedade paulista colonial, isto é, são constantes as afirmações de pobreza, subsistência, escravidão indígena como "remédio" para a miséria, isolamento, falta de comércio e igualdade na distribuição da riqueza. Tais idéias são ainda heranças da forte tendência historiográfica que dominou as primeiras décadas do século XX.

A atual historiografia, assentada em bases revisionistas, tem avançado consideravelmente nos últimos anos. Infelizmente, o mesmo não se pode dizer sobre a história de Taubaté. As páginas que se seguem visam contribuir modestamente para a inserção de tal história nas tendências atuais, lançando sobre ela novos pontos de vista. Assim, a preocupação nesse momento fixa-se na economia local e a composição existente quanto à distribuição da riqueza.

Algumas tabelas e gráficos foram elaborados com os dados obtidos na documentação compulsada a fim de possibilitar a caracterização dos aspectos econômicos da vila. A primeira delas, refere-se à composição da riqueza distribuída por setor econômico. Esta tabela permite visualizar os setores de maior ou menor investimento, o que revela a configuração dos interesses e das prioridades da sociedade. Antes de visualizá-la, é preciso definir os setores estabelecidos e os seus significados que foram denominados da seguinte forma ${ }^{258}$ :

1) Rural: bens relacionados às atividades rurais como terras, edificações, equipamentos, plantações, instrumentos de trabalho e rebanho;

\footnotetext{
${ }^{258}$ Por ser considerada bastante válida, esta divisão seguiu os moldes estabelecidos por Maurício Martins Alves, sofrendo somente algumas pequenas alterações. Cf. ALVES, Maurício Martins. Caminhos da Pobreza: a manutenção da diferença em Taubaté (1680-1729). Taubaté: Prefeitura Municipal, 1999.
} 
2) Urbano: casas e terrenos (chãos) na vila;

3) Escravos: índios e negros;

4) Ouro: ouro em pó, lavrado e quintado;

5) Prata: objetos de prata;

6) Padrão de Vida: vestuário, mobília da casa (o que inclui pratos de estanho, tachos de cobre, garrafas de vidro, imagens de santos, entre outros objetos);

7) Comércio: refere-se somente às mercadorias que estavam à venda;

8) Sertanismo: corresponde aos instrumentos típicos de armações sertanistas como armas de fogo, correntes com colares, pólvora, chumbo e armas brancas;

9) Dívidas Ativas: são as dívidas que se devem ao inventário;

10) Dívidas Passivas: são as dívidas que o inventário deve (o valor destas dívidas não foi somado ao monte-mor, e sim subtraído dele).

$\mathrm{Na}$ verdade, foram feitas duas tabelas. Uma expõe os valores reais e a outra a sua equivalente em porcentagem, assim, permitindo analisar as eventuais variações nos interesses econômicos da vila. Veja-se:

Tabela 1: Composição da riqueza em valores reais por setor econômico (Taubaté, 1650 a 1720)

\begin{tabular}{|c|c|c|c|c|c|c|c|}
\hline Item & 1650 & 1660 & 1670 & 1680 & 1690 & 1700 & 1710 \\
\hline Rural & $394 \$ 660$ & $201 \$ 330$ & $413 \$ 860$ & $1: 346 \$ 150$ & $1: 423 \$ 440$ & $5: 238 \$ 930$ & $7: 939 \$ 720$ \\
\hline Urbano & $18 \$ 800$ & $32 \$ 000$ & $99 \$ 200$ & $255 \$ 080$ & $552 \$ 680$ & $1: 599 \$ 840$ & $2: 440 \$ 020$ \\
\hline Escravo & $5: 456 \$ 000$ & $2: 877 \$ 000$ & $4: 770 \$ 000$ & $16: 429 \$ 720$ & $8: 784 \$ 400$ & $40: 153 \$ 120$ & $45: 311 \$ 000$ \\
\hline Ouro & $14 \$ 000$ & $53 \$ 100$ & $8 \$ 140$ & $70 \$ 000$ & $66 \$ 450$ & $5: 501 \$ 765$ & $28: 570 \$ 395$ \\
\hline Prata & $12 \$ 820$ & $64 \$ 240$ & $20 \$ 300$ & $76 \$ 700$ & $162 \$ 840$ & $843 \$ 590$ & $633 \$ 651$ \\
\hline Comércio & $63 \$ 540$ & 0 & 0 & $243 \$ 900$ & $142 \$ 390$ & $683 \$ 695$ & $5: 140 \$ 271$ \\
\hline P. Vida & $267 \$ 290$ & $299 \$ 140$ & $245 \$ 220$ & $503 \$ 280$ & $1: 546 \$ 640$ & $2: 647 \$ 270$ & $3: 694 \$ 530$ \\
\hline Div. Ativa & $168 \$ 800$ & $427 \$ 980$ & $197 \$ 158$ & $2: 155 \$ 088$ & $924 \$ 600$ & $8: 880 \$ 189$ & $22: 726 \$ 310$ \\
\hline Sertanismo & $47 \$ 430$ & $87 \$ 480$ & $78 \$ 220$ & $184 \$ 600$ & $370 \$ 460$ & $682 \$ 260$ & $371 \$ 040$ \\
\hline Monte-mor & $6: 394 \$ 020$ & $4: 042 \$ 270$ & $5: 832 \$ 098$ & $21: 264 \$ 518$ & $13: 973 \$ 900$ & $66: 391 \$ 609$ & $116: 826 \$ 937$ \\
\hline Div. Passiva & $610 \$ 003$ & $289 \$ 460$ & $1: 355 \$ 451$ & $3: 638 \$ 100$ & $1: 724 \$ 420$ & $10: 664 \$ 942$ & $19: 602 \$ 804$ \\
\hline $\begin{array}{l}\text { Monte- } \\
\text { menor }\end{array}$ & $5: 784 \$ 017$ & $3: 752 \$ 810$ & $4: 476 \$ 647$ & $17: 626 \$ 418$ & $12: 249 \$ 480$ & $55: 726 \$ 667$ & $97: 224 \$ 133$ \\
\hline Inventários & 18 & 20 & 23 & 34 & 33 & 33 & 36 \\
\hline
\end{tabular}

Fonte: Inventários (1649 a 1720). Arquivo Histórico Municipal de Taubaté. 
Tabela 2: Composição da riqueza em porcentagem por setor econômico (Taubaté, 1650 a 1720)

\begin{tabular}{lccccccc}
\hline Item & $\mathbf{1 6 5 0}$ & $\mathbf{1 6 6 0}$ & $\mathbf{1 6 7 0}$ & $\mathbf{1 6 8 0}$ & $\mathbf{1 6 9 0}$ & $\mathbf{1 7 0 0}$ & $\mathbf{1 7 1 0}$ \\
\hline Rural & 6,17 & 4,98 & 7,09 & 6,33 & 10,18 & 7,89 & 6,79 \\
Urbano & 0,29 & 0,79 & 1,70 & 1,19 & 3,95 & 2,40 & 2,08 \\
Escravo & 85,30 & 71,17 & 81,78 & 77,26 & 62,86 & 60,47 & 38,78 \\
Ouro & 0,21 & 1,31 & 0,13 & 0,32 & 0,47 & 8,28 & 24,45 \\
Prata & 0,20 & 1,58 & 0,34 & 0,36 & 1,16 & 1,27 & 0,54 \\
Comércio & 0,98 & 0 & 0 & 1,14 & 1,01 & 1,02 & 4,39 \\
P. Vida & 4,18 & 7,40 & 4,20 & 2,36 & 11,06 & 3,98 & 3,16 \\
Div. Ativa & 2,63 & 10,58 & 3,38 & 10,13 & 6,61 & 13,37 & 19,45 \\
Sertanismo & 0,74 & 2,16 & 1,34 & 0,86 & 2,65 & 1,02 & 0,31 \\
Monte-mor & $100 \%$ & $100 \%$ & $100 \%$ & $100 \%$ & $100 \%$ & $100 \%$ & $100 \%$ \\
& $6: 394 \$ 020$ & $4: 042 \$ 270$ & $5: 832 \$ 098$ & $21: 264 \$ 518$ & $13: 973 \$ 900$ & $66: 391 \$ 609$ & $116: 826 \$ 937$ \\
Div. Passiva & 9,54 & 7,16 & 23,24 & 17,10 & 12,34 & 16,06 & 16,77 \\
Monte-menor & $90,46 \%$ & $92,84 \%$ & $76,76 \%$ & $82,90 \%$ & $87,66 \%$ & $83,94 \%$ & $83,23 \%$ \\
& $5: 784 \$ 017$ & $3: 752 \$ 810$ & $4: 476 \$ 647$ & $17: 626 \$ 418$ & $12: 249 \$ 480$ & $55: 726 \$ 667$ & $97: 224 \$ 133$ \\
Inventários & 18 & 20 & 23 & 34 & 33 & 33 & 36 \\
\hline
\end{tabular}

Fonte: Idem.

A partir dos números acima, passa-se a fazer algumas considerações sobre os itens, não necessariamente na mesma ordem estabelecida nas tabelas. De maneira geral, percebese que dentro do curso histórico da vila, existem dois momentos a serem notados. Primeiro o período anterior à descoberta e exploração mineira, isso até a última década seiscentista, e o segundo refere-se aos vinte primeiros anos do século XVIII. Diga-se, desde já, que a base econômica da vila não sofre tantas alterações, apenas evolui ao longo do recorte cronológico. O que desperta a atenção é o seu rápido desenvolvimento, principalmente, após o ano de 1700, quando os frutos oriundos das minas já causam efeitos na dinâmica interna.

Observando as tabelas, é de fácil percepção a importância dada à mão-de-obra escrava e aos bens rurais. É certo que se está diante de uma economia essencialmente agrária e escravista, ou seja, uma imagem tipicamente colonial. Mesmo com o passar dos anos, tais itens estão entre os mais valorizados, tanto em termos reais, como em termos relativos. $\mathrm{O}$ alto percentual de riqueza depositada nos escravos índios, inicialmente, e depois nos negros africanos, permite dizer que Taubaté, como qualquer outra vila paulista, “(...) é uma sociedade inteiramente apoiada no índio e progredindo em função dele." ${ }^{259}$ A

\footnotetext{
${ }^{259}$ ZENHA, Edmundo. Mamelucos. São Paulo: Empresa Gráfica da Revista dos Tribunais, 1970. p.
} 1. 
questão da utilidade dessa mão-de-obra fez parte de diversas discussões historiográficas. Estão atreladas a estas discussões temas como a capacidade produtiva da economia paulista e o uso maciço de tantos braços escravos.

A antiga, mas persistente, idéia de que a região de São Paulo vivia isolada do resto da colônia, de que não tinha uma economia substancial, sendo apenas voltada para a mera subsistência, de que a pobreza grassava por toda a sociedade, pode ter influenciado as considerações feitas pelos estudiosos da história de Taubaté. Sob tal ponto de vista, assim como São Paulo, Taubaté e o vale do Paraíba também estariam inseridos no quadro descrito acima.

Sobre a caça e escravização indígena acreditava-se que a pobreza era o seu principal motivo. A pobreza era o estímulo para o amor ao sertão, a constante busca pelo seu "remédio"260. Também reinava a ideia de que "a produção pequena, os lucros insignificantes tornam as populações pobres em sua maioria, tanto em Guaratinguetá e Vale do Paraíba, como nas outras vilas de São Paulo."261 Na vertente deste raciocínio, o interesse na escravidão indígena não estava ligado à produção local.

Para Lucila Herrmann, “os escravos são raros e a subsistência da família é mantida pelo trabalho dos próprios membros e dos 'expostos'."262 Apesar de tal afirmação, sua obra não traz nenhum dado que sustente seus argumentos. De fato, a realidade parece ser muito diferente do que acredita a historiadora. Como se pode ver no gráfico de número 1, a porcentagem da população escrava - indígena e africana - supera a livre em todo o período estudado, constituindo praticamente no dobro dela. ${ }^{263}$ Ora, se a produção era apenas de subsistência e a mão-de-obra básica era formada pela própria família, duas questões vêm à tona: para onde iriam tantos índios escravizados? E seria mesmo a produção local uma fórmula voltada apenas à subsistência?

Existe ainda uma tradição historiográfica quando se fala em escravização indígena como atividade econômica comum aos paulistas. Como já afirmado em linhas anteriores,

\footnotetext{
${ }^{260}$ CALMON, Pedro. História do Brasil. Vol. II. 2 a . Ed. Rio de Janeiro: J. Olympio, 1963. p. 576.

261 HERRMANN, Lucila. Evolução da Estrutura Social de Guaratinguetá num Período de Trezentos Anos. São Paulo: Instituto de Pesquisas Econômicas/USP, 1986. p. 15.

${ }^{262}$ Idem, Ibidem. p. 15. Apesar desta obra focar Guaratinguetá, a autora costuma generalizar suas afirmações, estendendo-as a todo o vale do Paraíba, logo, Taubaté também faz parte dos quadros apresentados por ela.

${ }^{263}$ Ver o gráfico 1 na página 79.
} 
muitos acreditam que tal prática era um resultado natural da pobreza que assolava a região sul da colônia. Diante deste quadro, a caça e escravização dos índios era uma resposta "forçada" à difícil situação em que os paulistas viviam. Então, a solução seria utilizar o contingente humano escravo como mercadoria, vendendo-o para a maior e principal região produtora do Brasil, o nordeste açucareiro. É muito comum encontrar afirmações que defendem esta concepção. Gilberto Martins, ao discorrer sobre a péssima situação em que se encontrava a capitania de São Paulo, aponta o apresamento e venda de índios aos engenhos do Norte açucareiro como principal atividade econômica. ${ }^{264}$ Ele não é único a pensar assim. Myriam Ellis afirma que São Paulo estava no plano inferior no sistema econômico colonial, sobrevivendo apenas com uma policultura de subsistência, sendo o comércio de índios para outras regiões mais produtivas o único negócio verdadeiramente rentável, tão lucrativo que "chegavam a escassear nas lavouras paulistas, tal o êxodo forçado para outras capitanias, em certas épocas." 265 Há também o que diz Mafalda Zemella. Para ela "a crise da produção açucareira do Nordeste, refletindo-se na indústria do apresamento, obrigou o paulista a procurar outra atividade econômica e daí a intensificação, no último quartel do século XVII, das pesquisas de metais e pedras preciosas." ${ }^{266}$ Além da dependência para com o mercado nordestino, Zemella entende que as atividades de prospecção levadas a cabo pelos paulistas tinham ligação direta com a queda da produção açucareira, o que, sob o ponto de vista defendido nesta dissertação, não corresponde totalmente à realidade pois ainda existem questões de natureza externa que podem ter influenciado neste processo histórico. Enfim, para os estudiosos acima citados, a caça e escravização de índios estava relacionada à pobreza em que viviam os habitantes das capitanias do sul e o êxodo de tal mão-de-obra através do comércio seria a única atividade lucrativa, além de ser uma forma de inserção no circuito comercial da colônia.

Outra questão diz respeito à economia classificada como sendo de subsistência. Durante muito tempo, a historiografia defendeu a existência da pobreza geral encontrada em São Paulo, muito em função da sua suposta posição de isolamento. Em se tratando do vale do Paraíba e, mais precisamente, Taubaté, as concepções permanecem as mesmas. De

\footnotetext{
${ }^{264}$ MARTINS, Gilberto. Op. cit. p. 39.

${ }^{265}$ ELLIS, Myriam. “As Bandeiras na Expansão Geográfica do Brasil.” In: HOLANDA, Sérgio Buarque de. (org.) História Geral da Civilização Brasileira. Tomo I, Vol. I, Rio de Janeiro: Bertrand, 1989, p. 278.

${ }^{266}$ ZEMELLA, Mafalda P. Op. cit. p. 36.
} 
maneira geral, os estudiosos procuraram elaborar um quadro cronológico que traduzisse a evolução econômica da região. Para José Bernardo Ortiz e, na linha deste, Antonio Carlos de Argôllo Andrade e Maria Morgado de Abreu, assim definem as fases vividas pela economia taubateana: 1) de 1640 a 1690, predominância de uma atividade agro-pastoril de subsistência aliada ao ciclo de caça ao índio; 2) de 1690 a 1715, sobressai uma atividade agro-pastoril conjugada com o ciclo do ouro nas Gerais; por fim, 3) de 1715 em diante, uma atividade agro-pastoril com preponderância da cultura da cana-de-açúcar. Lucila Herrmann é mais enfática em dizer que o ciclo econômico de subsistência do vale do Paraíba pode ser visto entre 1630 a $1775 .^{267}$

Com vistas nas tabelas e quadros elaborados para esta pesquisa, é possível fazer algumas ressalvas quanto às afirmações feitas acima, mesmo porque acredita-se que houve um avanço na pesquisa documental, o que proporcionou a melhor visualização do panorama econômico do objeto em pauta.

Seguindo a atual tendência historiográfica, os dados obtidos permitem o questionamento do quadro econômico classificado como sendo apenas de subsistência. A grande presença de mão-de-obra escrava é um forte indício do desenvolvimento produtivo da vila de Taubaté. Como salientou John Manuel Monteiro, se a demanda por braços cativos existia é porque havia um mercado crescente que movimentava a dinâmica local e regional. ${ }^{268}$ Assim, com base na extensa população cativa existente na vila pode-se cogitar que a economia local se apresentava num estágio acima dos meros propósitos de subsistência, pois se estes fossem os objetivos únicos da vila, por que então a contínua demanda por mais braços? Aliás, por que uma suposta propriedade que visava apenas

${ }^{267}$ Cf. ORTIZ, José Bernardo. São Francisco das Chagas de Taubaté. Tomo II. Taubaté: Prefeitura Municipal de Taubaté, 1996. p. 407 e 408; ANDRADE, Antonio Carlos de Argôllo; ABREU, Maria Morgado de. História de Taubaté Através de Textos. 2a. ed. Taubaté: Prefeitura Municipal de Taubaté, 2004. p. 60; HERRMANN, Lucila. Evolução da Estrutura Social de Guaratinguetá num Período de Trezentos Anos. São Paulo: Instituto de Pesquisas Econômicas/USP, 1986. p. 13.

${ }^{268}$ Diz este historiador: "o ponto de partida é a simples constatação de que as frequentes incursões ao interior, em vez de abastecerem um suposto mercado de escravos índios no litoral, alimentavam uma crescente força de trabalho indígena no planalto, possibilitando a produção e o transporte de excendentes agrícolas; assim, articulava-se a região da chamada Serra Acima a outras partes da colônia portuguesa e mesmo ao circuito mercantil do Atlântico meridional." MONTEIRO, John Manuel. Op. cit. p. 8. 
manter a subsistência familiar poderia possuir dezenas e até centenas índios, senão para aumentar sua produção para fins comerciais? $?^{269}$

O crescimento e a variação nos tipos de cultura também ajudam a argumentação que defende a presença de uma economia comercial ainda no século XVII. A tabela abaixo procura demonstrar que desde muito cedo havia um cultivo de produtos muito visados para o comércio. Lamenta-se que o tipo de documentação utilizado não forneça dados sobre a quantidade produzida. Todavia, assim como para Maurício Martins Alves, acredita-se que a relação entre o número de mão-de-obra existente mais a própria declaração da plantação em inventário sejam indícios de que a produção agrária tinha algum valor monetário já que faziam parte dos bens arrolados no inventário e que, por isso mesmo, poderiam ser motivo para disputas entre herdeiros. ${ }^{270}$

\footnotetext{
${ }^{269}$ São os casos de Bartolomeu da Cunha Gago que possuía 256 índios, Domingos Pires Valadão que tinha 50, Antonio de Faria Albernaz com 40, além de muitos outros que estenderiam em muito esta exemplificação. Ver: Inventário de Bartolomeu da Cunha Gago (1685) Cx: 1678-1689. Inventário de Domingos Pires Valadão (1660) Cx: 1649-1667. Inventário de Antonio de Faria Albernaz (1663) Cx: 1649-1667. Todos pertencentes ao Arquivo Histórico Municipal de Taubaté.

${ }^{270}$ Para este autor "a produção de mantimentos não deve ser vista como apenas o mínimo para sobrevivência das pessoas que o produzem, mas representa uma produção em tamanho considerado suficientemente grande para ser arrolado e dividido entre os herdeiros. Fosse pequena demais esta produção, impossibilitaria a partição e não teria sentido arrolá-la (quando muito, um acordo entre as partes resolveria o problema). Assim, é possível supor que parte desta produção de mantimentos constitui uma atividade monetarizada, ao menos para ter seu preço em réis declarado para efeito de arrolamento no inventário e, talvez, seja grande o suficiente para ser vendida." ALVES, Maurício Martins. Formas de Viver: formação de laços parentais entre cativos em Taubaté, 1680-1848. Tese de Doutorado, Universidade Federal do Rio de Janeiro, 2001. p. 20.
} 


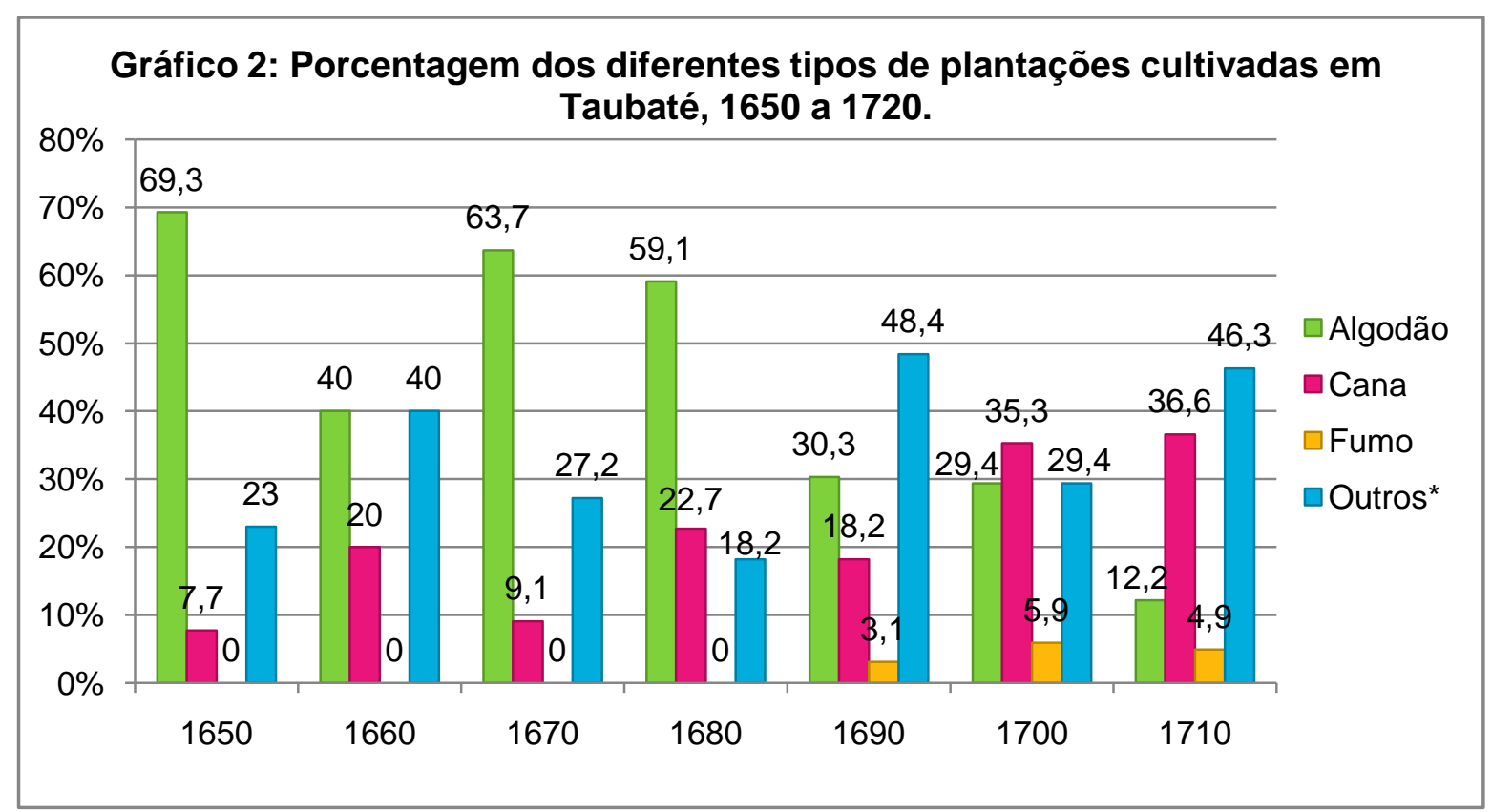

Fonte: Inventários (1649 a 1720). Arquivo Histórico Municipal de Taubaté.

* Refere-se, aqui, basicamente a milho, mandioca e feijão.

Com o passar dos anos, conforme a vila se solidificava, as plantações aumentavam em quantidade e diversidade. Com destaque para a década de 1680 que mostra um salto na porcentagem de fazendas produzindo cana e algodão, década esta, aliás, a que apresenta a maior porcentagem de população escrava da vila. ${ }^{271} \mathrm{O}$ período seguinte segue a tendência de crescimento, principalmente em relação aos gêneros alimentícios classificado no gráfico como "outros" que sobe de $18,2 \%$ para $48,4 \%$ do total de plantações, surgindo também, pela primeira vez, a menção à produção de fumo. No entanto, há um declínio no item algodão.

As décadas de 1700 e 1710 sofreram os reflexos dos fatos ocorridos na década anterior. O panorama é muito interessante, pois denuncia uma mudança no ritmo da vila. Em todos os sentidos, seja populacional ou econômica, as transformações são bastante visíveis. Juntamente com o retorno de muitas pessoas das minas, há uma diversificação nas fazendas produtivas. As preferências pelos tipos de cultivo podem estar ligadas ao destino dado à produção, e o grande mercado no momento era a região das lavras mineiras. Decresce a produção de algodão, produto, aliás, mais voltado ao mercado local, dando lugar aos itens com maior demanda, com destaque para os gêneros de primeira necessidade

${ }^{271}$ Cf. o gráfico 1 na página 79. 
como os alimentos e, em seguida, a cana e seus derivados, principalmente, a aguardente. ${ }^{272}$ Percebe-se, assim, que a experiência dos habitantes de Taubaté nos ambientes ligados às lavras pode ter influenciado na escolha dos ramos de maior produção, ou melhor, nos tipos de cultivo, visando, logicamente, aqueles que tinham maior grau de comercialização. Há que se reconhecer que a abertura de um novo mercado consumidor gerou reflexos positivos no quadro econômico da vila, como o aumento na produção e a sua elevação nos tratos mercantis, mas isso só foi possível porque já existia uma base assentada capaz de acompanhar as oportunidades, isto é, já havia antes mesmo do século XVIII um sistema agrário produtivo (em pequena escala, é verdade) e um contingente de mão-de-obra escrava disponíveis na vila.

Ao contrário do que pensam aqueles autores que enxergam em Taubaté apenas uma policultura de subsistência, que sobrevivia à custa do trabalho familiar, e que só teve algum desenvolvimento após o descobrimento do ouro, é preciso ter em mente que a lógica comercial de abastecimento local e regional também fazia parte do sistema colonial. Como ressalta John Monteiro, com o crescimento da economia açucareira do Nordeste, muitas regiões consideradas secundárias, no caso São Paulo, tiveram oportunidades de desenvolvimento econômico através da criação de gado e da produção de gêneros de abastecimento. ${ }^{273}$ Depois de longas e duras discussões sobre a economia colonial, hoje reconhece-se a importância da produção e comercialização de gêneros para o abastecimento das regiões agro-exportadoras para a formação de um vigoroso e dinâmico mercado interno, o que possibilitava, em certa medida, "acumulações endógenas" no espaço colonial. ${ }^{274}$ Tal dinâmica contribuiu para a geração de circuitos mercantis inter e intraregionais, com destaque para São Paulo, Rio de Janeiro, Minas Gerais e colônias do Sul.

${ }^{272}$ Em seu testamento, Bartolomeu Bueno de Mendonça registra que deu "ao Coronel Salvador Fernandes [Furtado de Mendonça] um barril de aguardente que levou um negro alugado de Bento Pires para o vender nas minas." Note-se que são nomes extremamente conhecidos no rol dos sertanistas. Há ainda outros casos como o encontrado no inventário de Bernarda de Souza da Silveira, filha do famoso Carlos Pedroso da Silveira, onde está escrito dever a fazenda Francisco Alves Correa, o Moço, "um barril de aguardente que lhe entregou nas minas." Cf. Testamento de Bartolomeu Bueno de Mendonça (1704). Cx:1704-1717. Inventário de Bernarda de Souza da Silveira (1710). Cx: 1709-1715. A.H.M.T.

${ }^{273}$ MONTEIRO, John Manuel. Op. cit. p. 100.

${ }^{274}$ Cf. FLORENTINO, Manolo; FRAGOSO, João. O Arcaísmo como Projeto: mercado atlântico, sociedade agrária e elite mercantil em uma economia colonial tardia: Rio de Janeiro, c.1790 c.1840. Rio de Janeiro: Civilização Brasileira, 2001; FRAGOSO, João Luiz Ribeiro. Homens de 
Voltando a Taubaté, apesar do pouco que foi encontrado sobre o destino dos produtos locais além de algumas vilas vizinhas e litorâneas, a própria existência de terras produtivas e a grande quantidade de mão-de-obra escrava indicam uma dinâmica produtivacomercial acima do que se entende por economia de subsistência.

Muito se diz sobre a falta de comércio como pressuposto para a predominância de uma economia de subsistência. Para alguns autores, uma coisa estava inteiramente ligada à outra. Por exemplo, sobre o período entre 1640 e 1690, dizem que:

nessa primeira fase econômica de Taubaté e região, todas as atividades produtivas, limitavam-se apenas ao abastecimento local, isto é, destinavam-se somente ao consumo interno, pois nessa época, o comércio regional era praticamente inexistente e, se existia, era na base do escambo (troca de mercadorias) e, assim mesmo, em pequena quantidade. ${ }^{275}$

Seguindo este raciocínio, o escambo não figurava como uma prática consistente a ponto de ser considerado comércio. Ora, numa realidade colonial, onde o numerário era escasso, como movimentar a dinâmica comercial senão por meio do escambo? Aliás, e os chamados "conhecimentos", não faziam parte do exercício comercial cotidiano? Na própria documentação, são arrolados inúmeros "conhecimentos" que correspondem a antigos tratos comerciais. Entende-se assim que a falta de numerário e o escambo não são motivos para justificar uma suposta inexistência de comércio.

Nas tabelas 1 e 2, o que se registra sobre o item "comércio" deve ser melhor explicado. Lá, os dados se referem especificamente às mercadorias que estavam à venda, ou seja, bens destinados exclusivamente ao comércio comumente estabelecidos nas chamadas "lojas". Trata-se de pessoas, em sua maioria, ligadas apenas à atividade comercial. Como o número de lojas na vila era muito baixo, pelo menos até a década de 1690, as tabelas mostram a sua pequena importância frente aos outros itens. ${ }^{276}$ Mas perceba-se que logo

Grossa Ventura: acumulação e hierarquia na praça mercantil do Rio de Janeiro, 1790-1830. Rio de Janeiro: Civilização Brasileira, 1998. Apesar das críticas feitas às teses destes autores, muito em função de problemas metodológicos e contextuais, os avanços no conhecimento do mercado interno colonial abriram caminho para novas abordagens sobre o assunto. Sobre as críticas. Cf. SCHWARTZ, Stuart B. Segredos internos: engenhos e escravos na sociedade colonial. São Paulo: Companhia das Letras, 1988.

${ }^{275}$ ANDRADE, Antonio Carlos de Argôllo; ABREU, Maria Morgado de. Op. cit. p.60.

${ }^{276}$ De fato, o que se pôde constatar foi a presença de apenas uma loja, sendo seu responsável um estrangeiro, natural de Gênova, chamado Bernardo Bonfillio. Cf. Inventário de Bernardo Bonfillio (1681). Cx: 1678-1689. A.H.M.T. O testamento encontra-se anexado ao inventário. 
após 1700, tal ramo só tende a ocupar maior espaço. ${ }^{277}$ Como o grosso do comércio era feito pelas pessoas comuns, não detentoras de lojas, não foi possível quantificar a produção voltada ao comércio. Muitas vezes até eram declaradas transações comerciais, porém estas servem apenas para comprovar a existência delas.

Como se viu, os anos que seguem as descobertas das minas foram marcados por uma injeção de riquezas na vila de Taubaté, além da abertura de um novo mercado consumidor que, em conjunto, possibilitaram mudanças bastante significativas. A disponibilidade de liquidez através do ouro ocupou lugar importante neste contexto.

As décadas de 1700 e 1710 vivenciaram uma considerável injeção de ouro. Observando novamente os números apresentados na tabela 1, logo se percebe o salto ocorrido: na década de 1690, o ouro representado em valores corresponde a $66 \$ 450$ réis, já nas décadas seguintes os valores sobem para 5:501\$765 e depois para 28:570\$395. ${ }^{278} \mathrm{~A}$ circulação de riquezas, seja ela via comércio ou empréstimos, favoreceu de imediato fortes mudanças na configuração da vila. Em termos de valores, há o crescimento em todos os setores indicados nesta pesquisa, o que significa dizer que a liquidez oriunda das Minas impulsionou a dinâmica econômica interna gerando, com isso, maiores oportunidades de negócio. Ressalta-se o uso da palavra "impulsionou” e não "criou”, pois acredita-se que, assim como Ilana Blaj observou em relação a vila de São Paulo, a abertura de um novo mercado possibilitou o crescimento dos setores produtivos das áreas periféricas, setores estes que não foram criados em prol das minas pois já existiam e viviam a sua própria lógica econômica muito antes das descobertas oficiais dos fins do século XVII. ${ }^{279}$ Assim toma-se, aqui, a influência mineira na economia local da vila de Taubaté como um elemento propulsor que acelerou o seu processo de "mercantilização". A inserção de mãode-obra escrava de origem africana, o aumento da produtividade de cana-de-açúcar, a valorização do setor urbano e, por último, mas não menos importante, o maior fluxo nas

${ }^{277}$ Foram encontrados os registros de duas lojas que estavam em funcionamento na década de 1710. Cf. Inventário de Margarida Bicuda (1716) e de Pedro da Fonseca de Carvalho (1718). Cx: 17161719. A.H.M.T.

${ }^{278}$ Cf. página 88 .

${ }^{279}$ Para Ilana Blaj, não foi a demanda do mercado mineiro que forçou a criação da produtividade agro-pecuária em São Paulo, como quer, por exemplo, Mafalda Zemella. Blaj diz que "é o desenvolvimento da vila de São Paulo e de seus arredores que explica a possibilidade do abastecimento do mercado mineiro, e não o contrário." Cf. BLAJ, Ilana. Op. cit. p. 205. ZEMELLA, Mafalda P. Op. cit. 
transações comerciais, dentre elas o adiantamento e endividamento, são indícios de tal processo.

As chamadas "dívidas ativas" e "dívidas passivas" estão entre os itens que mais receberam investimento ao longo do período estudado. Como já apontado, a ausência de moeda não era motivo que pudesse levar à inexistência de relações comerciais. O escambo como prática bastante utilizada, além da feitura dos "conhecimentos", era alternativa muito eficaz neste contexto e que mantinha em funcionamento toda a economia local.

Em estudo recente, Milena Fernandes Maranho dispensou grande atenção ao papel das dívidas numa economia colonial. ${ }^{280}$ Com o objetivo de entender os significados econômicos existentes na região do Planalto de Piratininga entre os anos de 1648 e 1682, Maranho detectou alguns aspectos que merecem destaque: 1) ela percebeu que a condição de "pobreza" pode ser uma justificativa utilizada pelos colonos para a obtenção de sesmarias, para o não pagamento de impostos e, principalmente, para a legitimação da caça de índios; 2) que a pobreza geral, muito difundida pela historiografia, deve ser relativizada levando em conta o peso dado pelas dívidas durante a vida econômica das pessoas.

O primeiro ponto salientado, tem muito a ver com o que a historiografia tradicional tem a dizer sobre o assunto. Para alguns autores, como Ernani Silva Bruno, por exemplo, o isolamento geográfico de São Paulo levava à pobreza e esta, por sua vez, gerava a necessidade das constantes buscas no sertão do denominado "remédio" para o alívio de tal situação, ou seja, o bandeirismo de apresamento era uma resposta às dificuldades encontradas na realidade. ${ }^{281}$ Nessa ótica, a escravização indígena constituía um "mal necessário". No entanto, os antigos estudiosos não questionaram as intencionalidades imbricadas nas declarações de pobreza feitas pelos próprios colonos, aceitaram as “confissões" encontradas na documentação como relatos fiéis à realidade. Não se perguntaram sobre os significados de tais declarações. Daí, o valor das reflexões trazidas por Maranho, que encontrou nas condições tidas como de pobreza não apenas uma resposta a uma realidade, mas também como uma maneira de justificar a caça e a escravização dos índios, uma espécie de "desculpa" para a legitimação dessas ações que eram, em teoria,

${ }^{280}$ MARANHO, Milena Fernandes. A Opulência Relativizada: significados econômicos e sociais dos níveis de vida dos habitantes da região do Planalto de Piratininga (1648-1682). Dissertação de Mestrado: Unicamp, 2000.

${ }^{281}$ Cf. BRUNO, Ernani Silva. História e Tradições da Cidade de São Paulo - Arraial de Sertanistas (1554-1828). Rio de Janeiro: Livraria José Olympio Editora, 1953. 
proibidas. Além disso, usava-se a pobreza como forma de adquirir terras e isenção de impostos.

A idéia de "pobreza geral" que assolava São Paulo tem, hoje, os seus problemas. Como dito no segundo ponto de destaque, por muito tempo a historiografia aceitou e difundiu a ausência de riqueza em terras piratininganas e, mais amplamente, em todas as capitanias do sul. A fórmula utilizada para se definir a presença ou não da riqueza local pode ser exemplificada pelos estudos de Alcântara Machado, em sua famosa obra Vida $e$ Morte do Bandeirante. Nela, o autor se apoiou nas descrições dos bens e seus respectivos valores encontrados nos inventários post mortem e, dessa maneira, classificou os indivíduos que eram pobres e os que eram ricos. Machado, defendendo a pobreza geral e buscando contrariar a possível condição nobre dos paulistas, defendida principalmente pelos linhagistas, diz o seguinte: "daí se conclui quanto se distanciam da realidade os que se fiam cegamente na palavra dos linhagistas. Dos quatrocentos inventários seiscentistas, há apenas vinte que delatam alguma abastança. Cinco por cento." 282 Pois bem, a conclusão parece fazer sentido, mas ainda há que se levar em conta o papel exercido pelas dívidas, coisa que Alcântara Machado não fez.

Não é seguro tomar apenas a posse de bens como indicador de riquezas. Reconhecidamente como uma prática cotidiana, os empréstimos eram fundamentais numa economia colonial. Além de serem muito usados em transações comerciais, serviam também como forma de manutenção do status social, seja como um meio utilizado para a aquisição de bens, seja como uma atividade econômica, muito rentável por sinal. Tais práticas não eram ações isoladas, ao contrário, estavam presentes nas mais diferentes situações. ${ }^{283}$ Então, ratifica-se aqui a idéia sustentada por Maranho de que "o crédito movia a economia e a sociedade 'paulista', e era mantido durante toda a vida daquelas pessoas

\footnotetext{
${ }^{282}$ MACHADO, Alcântara. Vida e Morte do Bandeirante. Coleção Paulística. Vol. XIII. São Paulo: Imprensa Oficial, 2006. p. 44.

283 Júnia Ferreira Furtado, citando um documento coevo, salientou que "embora os mineiros tivessem acesso direto ao ouro, referência universal de troca, 'o estilo observado nestas Minas, depois que elas se descobriram até o presente, foi sempre o comprar-se tudo fiado, a pagamento de um ano, ano e meio e dois anos, e não há coisa nenhuma que se compre que seja com pagamento a vista, senão fiada'. O mescanismo de endividamento que a população se encontrava em relação aos comerciantes era enorme." FURTADO, Júnia Ferreira. Homens de Negócio: a interiorização da metrópole e o comércio das minas setecentistas. $2^{\mathrm{a}}$. ed. São Paulo: Hucitec, 2006. p.119-120. A citação por ela utilizada foi extraída em "Transcrição da segunda parte do código da Seção colonial." Revista do Aquivo Público Mineiro. 1980. Ano 31. p. 261.
} 
através de uma ostentação de bens muitas vezes financiada pelos empréstimos."284 Em outras palavras, o crédito favorecia a manutenção não só do sistema econômico, mas também o padrão de vida de muitas pessoas que viviam, no dizer da autora, numa "riqueza aparente".

Em termos de presença dos empréstimos na circulação de riquezas e na movimentação de uma economia local, a vila de Taubaté parece seguir na mesma linha. Atentando-se novamente às tabelas 1 e 2, vê-se que é bastante considerável a parcela de riqueza depositada nas dívidas ativas e passivas. Apesar das variações sofridas ao longo do período analisado, elas estão sempre entre os itens mais valorizados. Chama a atenção o forte crescimento, tanto da prática como da importância delas, nas décadas a partir de 1700, o que mais uma vez denota as mudanças ocorridas com a injeção de ouro na vila. A economia ao se aquecer com a disponibilidade de liquidez permite, quase que automaticamente, o aumento dos adiantamentos/endividamentos que eram, como se viu, fundamentais para as transações comerciais. Além desta constatação, a origem das dívidas pode dizer muito sobre a vida econômica local. A tabela abaixo expõe as taxas referentes às dívidas ativas e passivas e suas respectivas origens.

Tabela 3: Origem das Dívidas encontradas em Taubaté, 1650 a 1720.

\begin{tabular}{ccccccc}
\hline & \multicolumn{3}{c}{ Dívidas Ativas } & \multicolumn{3}{c}{ Dívidas Passivas } \\
\hline & Interna & Externa & Total & Interna & Externa & Total \\
$\mathbf{1 6 5 0}$ & $121 \$ 000$ & $47 \$ 800$ & $168 \$ 800$ & $473 \$ 483$ & $136 \$ 520$ & $610 \$ 003$ \\
$\mathbf{1 6 6 0}$ & $349 \$ 640$ & $78 \$ 340$ & $427 \$ 980$ & $208 \$ 460$ & $81 \$ 000$ & $289 \$ 460$ \\
$\mathbf{1 6 7 0}$ & $137 \$ 198$ & $59 \$ 960$ & $197 \$ 158$ & $1: 146 \$ 551$ & $208 \$ 900$ & $1: 355 \$ 451$ \\
$\mathbf{1 6 8 0}$ & $1: 874 \$ 935$ & $280 \$ 153$ & $2: 155 \$ 088$ & $2: 981 \$ 790$ & $656 \$ 310$ & $3: 638 \$ 100$ \\
$\mathbf{1 6 9 0}$ & $855 \$ 000$ & $163 \$ 200$ & $1: 018 \$ 200$ & $1: 551 \$ 840$ & $172 \$ 580$ & $1: 724 \$ 420$ \\
$\mathbf{1 7 0 0}$ & $8: 627 \$ 789$ & $252 \$ 400$ & $8: 880 \$ 189$ & $8: 226 \$ 712$ & $1: 258 \$ 230$ & $9: 484 \$ 942$ \\
$\mathbf{1 7 1 0}$ & $21: 843 \$ 650$ & $834 \$ 660$ & $22: 678 \$ 310$ & $16: 820 \$ 157$ & $2: 778 \$ 647$ & $19: 598 \$ 804$ \\
\hline
\end{tabular}

Fonte: Inventários (1649 a 1720). Arquivo Histórico Municipal de Taubaté.

De imediato, percebe-se a predominância da origem interna das dívidas sobre a externa em todo o período considerado. Apesar das variações, esta era a regra. Entretanto, outras considerações podem ser feitas sobre os dados.

Primeiro, com relação às dívidas externas, as décadas de 1650 e 1660, e até mesmo a de 1670, apresentam valores mais elevados do que o restante dos anos. Talvez por ser

${ }^{284}$ MARANHO, Milena Fernandes. Op. cit. p. 89. 
parte de um momento caracterizado por uma aparente instabilidade da vila, período que ao mesmo tempo também é representativo de uma incipiente migração, as relações de dependência para com outras regiões sejam ainda necessárias e até inevitáveis. Pelo menos em se tratando das dívidas ativas tal dependência diminui bastante com o despertar do século XVIII devido à injeção de riqueza que houve na vila. Já com relação às dívidas passivas, os valores diminuem com o tempo mas não são menores que $172 \$ 580$ mil réis, o que mostra ainda as ligações estabelecidas com outras localidades regidas sob a forma de compromissos financeiros. A bem da verdade, a manutenção das dívidas passivas pode estar atada ao comércio de mercadorias, pois há casos que exemplificam tal situação. Além disso, o conjunto dos dados mostra uma realidade de comunicação entre diferentes áreas, seja via comércio ou empréstimo, isso não importa, o que interessa realmente é que Taubaté e o vale do Paraíba não eram isolados. Havia contatos com muitas localidades como Rio de Janeiro, Parati, Ubatuba, São Paulo, Mogi das Cruzes, Santos, entre outras, que permitia a circulação de riquezas. ${ }^{285}$ Enfim, isto tudo contraria a ideia de isolamento geográfico e econômico-comercial, como crêem alguns autores. ${ }^{286}$

Todavia, os contatos com outras localidades não significam uma total dependência em termos financeiros. Não obstante a existência das dívidas passivas externas, o que seria o mesmo que a saída de riqueza, a tabela mostra que a vila detinha grande parte dos recursos financeiros de que necessitava. Tal reserva aumenta como reação à presença de ouro que inflama ainda mais as atividades comerciais, em especial os próprios adiantamentos e endividamentos. Portanto, “(...) pode-se atribuir ao ouro a formação de uma liquidez de tal monta que possibilita a montagem de uma rede de

285 A título de exemplo, no inventário de Bernardo Bonfillio é possível identificar contatos comerciais com o Rio de Janeiro, Ilha Grande, Paraty, Guaratinguetá, Ubatuba, São Sebastião e até com a Bahia. Ver: Inventário de Bernardo Bonfillio (1681). Cx: 1678-1689. A.H.M.T.

${ }^{286}$ Rangel diz que "as dificuldades de transposição da Serra do Mar, a inexistência de fluxos de comércio exterior e o fato de não apresentar vantagens imediatas para os interesses mercantis metropolitanos, conduziram ao relativo estado de isolamento em que permaneceu a Capitania de São Vicente até o advento da mineração. Em meio ao isolamento, conformou-se no planalto uma economia desvinculada das linhas do comércio colonial e uma organização da sociedade relativamente à margem da administração colonial portuguesa, em que a pobreza e a rudeza de sua população parecem ter sido marcantes.” RANGEL, Armênio de Souza. Op. cit. p. 3. Ilana Blaj que, em importante estudo, questiona antigas concepções também não vê tal isolamento. Para ela "a região de Piratininga não era tão isolada e pobre como vários autores acreditam." BLAJ, Ilana. Op. cit. p.109. 
adiantamento/endividamento residente e autônoma." ${ }^{287}$ É preciso deixar claro que ser autônoma não significava ser isolada. A autonomia aqui defendida corresponde à ideia de que a vila detinha recursos suficientes para manter sua economia em funcionamento.

Até agora, foram vistas as principais áreas da economia de Taubaté e as relativas importâncias atribuídas a elas, cada qual com a sua respectiva variação. Buscou-se revisar algumas concepções historiográficas sobre o assunto, por um lado, e preencher algumas lacunas que ainda permaneciam, por outro. O leitor atento deve ter percebido que não se discorreu sobre o item "sertanismo", e isso ocorreu propositalmente porque será o tema do capítulo seguinte. Mas antes disso, é necessário ainda entrar em outro campo de análise: a sociedade taubateana propriamente dita, isto é, procurar-se-á mostrar adiante a localização e distribuição da sociedade na realidade econômica exposta acima.

\subsection{Desigualdade Social e Interesses Econômicos Variados}

A preocupação aqui é tentar verificar a existência ou não de divisões sociais entre a população livre da vila de Taubaté. Como é sabido, era muito comum na sociedade colonial a solidificação de estratos sociais diferenciados não só entre homens livres e a massa escrava, mas também entre os próprios não-cativos. Assim, verticalmente tinha-se a desigualdade de condição (escravos e livres) e horizontalmente havia as diferentes posições entre pessoas livres (ou forras) que eram condicionadas, principalmente, pela posse de cabedal econômico, além da ontentação de símbolos nobilitadores.

Foram elaboradas tabelas que mostram as divisões da riqueza mapeada na vila durante todo o período de estudo, separadas por décadas. Com os valores levantados, a atenção se direcionou no sentido de situá-los em determinadas faixas de riqueza referentes à posse de cada inventário, assim foi possível relacionar a quantidade de riqueza com a parcela da população que a possuía.

O objetivo imbricado na confecção destas tabelas está ligado às motivações revisionistas presentes na historiografia atual. Tanto na história de São Paulo quanto na de Taubaté, é bastante difundida a ideia da existência de uma democracia sócio-econômica na população estabelecida nestas partes. Para alguns estudiosos, as vilas paulistas eram, até o

287 ALVES, Maurício Martins. Caminhos da Pobreza: a manutenção da diferença em Taubaté (1680-1729). Taubaté: Prefeitura Municipal, 1999. p. 92. 
século XVIII, constituídas apenas por uma população de pequenos proprietários policultores, onde ainda se achava instalada a estrutura escravocrata. ${ }^{288}$ Não é difícil de encontrar textos que defendem a existência de "uma riqueza bem distribuída". ${ }^{289}$ Muito do que se escreveu com relação às características sócio-econômicas da população paulista colonial está assentada naquelas antigas concepções historiográficas acerca da pobreza, do isolamento, da altivez e do espírito igualitário do homem paulista. Dentro desta vertente, não havia espaço para as desigualdades. Pois bem, apesar de algumas destas imagens ainda permanecerem em obras não tão distantes no tempo, sua revisão é parte da tendência historiográfica atual. Nesse sentido, as tabelas abaixo visam dar as suas contribuições.

Tabela 4: Distribuição dos inventários dos habitantes de Taubaté segundo as diferentes faixas de riqueza bruta (1650)

\begin{tabular}{cccccc}
\hline & \multicolumn{2}{c}{ Riqueza Bruta } & \multicolumn{2}{c}{ Inventários } \\
\hline $\begin{array}{c}\text { Faixa de } \\
\text { Riqueza (mil } \\
\text { réis) }\end{array}$ & $\begin{array}{c}\text { Soma dos } \\
\text { Montes }\end{array}$ & $\mathbf{( \% )}$ & $\begin{array}{c}\mathbf{N}^{\mathbf{0}} \text {. } \\
\text { Absoluto }\end{array}$ & $\mathbf{( \% )}$ & $\begin{array}{c}\text { Riqueza } \\
\text { Média }\end{array}$ \\
0 a 499 & $1: 264 \$ 590$ & 19,8 & 12 & 66,6 & $105 \$ 382$ \\
$\mathbf{5 0 0}$ a 999 & $3: 186 \$ 370$ & 49,8 & 5 & 27,8 & $637 \$ 274$ \\
$\mathbf{1 0 0 0}$ a 1999 & $1: 943 \$ 060$ & 30,4 & 1 & 5,6 & $1: 943 \$ 060$ \\
2000 a 2999 & - & - & - & - & - \\
3000 a 5000 & - & - & - & - & - \\
Mais de 5000 & - & - & - & - & - \\
Total & $6: 394 \$ 020$ & 100 & 18 & 100 & $355 \$ 223$ \\
\hline
\end{tabular}

Fonte: Inventários (1649 a 1720). Arquivo Histórico Municipal de Taubaté.

Tabela 5: Distribuição dos inventários dos habitantes de Taubaté segundo as diferentes faixas de riqueza bruta (1660)

\begin{tabular}{cccccc}
\hline & \multicolumn{2}{c}{ Riqueza Bruta } & \multicolumn{2}{c}{ Inventários } \\
\hline $\begin{array}{c}\text { Faixa de } \\
\text { riqueza (mil } \\
\text { réis) }\end{array}$ & $\begin{array}{c}\text { Soma dos } \\
\text { montes }\end{array}$ & $\mathbf{( \% )}$ & $\mathbf{N}^{\mathbf{0}}$. absoluto & $\mathbf{( \% )}$ & $\begin{array}{c}\text { Riqueza } \\
\text { Média }\end{array}$ \\
$\mathbf{0}$ a 499 & $2: 370 \$ 110$ & 58,6 & 18 & 90,0 & $131 \$ 672$ \\
$\mathbf{5 0 0}$ a 999 & $662 \$ 100$ & 16,4 & 1 & 5,0 & $662 \$ 100$ \\
$\mathbf{1 0 0 0}$ a 1999 & $1: 010 \$ 060$ & 25,0 & 1 & 5,0 & $1: 010 \$ 060$ \\
$\mathbf{2 0 0 0}$ a 2999 & - & - & - & - & - \\
3000 a 5000 & - & - & - & - & - \\
Mais de 5000 & - & - & - & - & - \\
Total & $4: 042 \$ 270$ & 100 & 20 & 100 & $202 \$ 113$ \\
\hline
\end{tabular}

Fonte: Idem.

${ }^{288}$ Cf. HERRMANN, Lucila. Op. cit. p. 21-22.

${ }^{289}$ Cf. ORTIZ, José Bernardo. São Francisco das Chagas de Taubaté. Tomo II. Taubaté: Prefeitura Municipal, 1996. p. 60. 
Tabela 6: Distribuição dos inventários dos habitantes de Taubaté segundo as diferentes faixas de riqueza bruta (1670)

\begin{tabular}{cccccc}
\hline \multicolumn{2}{c}{ Riqueza Bruta } & \multicolumn{2}{c}{ Inventários } \\
\hline $\begin{array}{c}\text { Faixa de } \\
\text { riqueza (mil } \\
\text { réis) }\end{array}$ & $\begin{array}{c}\text { Soma dos } \\
\text { montes }\end{array}$ & $(\%)$ & $\mathbf{N}^{\mathbf{0}}$. absoluto & $(\%)$ & $\begin{array}{c}\text { Riqueza } \\
\text { Média }\end{array}$ \\
$\mathbf{0}$ a 499 & $4: 384 \$ 838$ & 75,2 & 22 & 95,7 & $199 \$ 310$ \\
$\mathbf{5 0 0}$ a 999 & - & - & - & - & - \\
$\mathbf{1 0 0 0}$ a 1999 & $1: 447 \$ 260$ & 24,8 & 1 & 4,3 & $1: 447 \$ 260$ \\
$\mathbf{2 0 0 0}$ a 2999 & - & - & - & - & - \\
$\mathbf{3 0 0 0}$ a 5000 & - & - & - & - & - \\
Mais de 5000 & - & - & - & - & - \\
Total & $5: 832 \$ 098$ & 100 & 23 & 100 & $253 \$ 569$ \\
\hline
\end{tabular}

Fonte: Idem.

As tabelas acima, representantes das três primeiras décadas do estudo, são bastante claras quanto as suas objetividades. É de fácil percepção a desigualdade na distribuição da riqueza encontrada na vila. Nas três amostragens, uma parcela mínima dos inventários analisados, isto é, $5,6 \%, 5 \%$ e 4,3\% deles, detém um percentual de riqueza que corresponde de $24,8 \%$ até $30,4 \%$. Isto significa que poucas pessoas se destacavam economicamente, estando a grande maioria da população vivendo no mesmo padrão social, mas isto não nivela a sociedade a ponto de anular as desigualdades, apenas demonstra que o padrão de riqueza e as oportunidades de investimento eram ainda comuns a todos. Talvez por ser o tal período ainda de consolidação da economia local, um momento ainda de solidificação da vila, a dinâmica econômica permitia o pequeno destaque de atividades que se desvinculassem da prática comum, sendo algumas exceções aqueles que se viam à frente no padrão de posse de riquezas. Além do que, o nível de riqueza ainda parece ser baixo na vila, pois os mais ricos estavam entre a faixa correspondente a um conto de réis até 1:999\$000.

Com o passar dos anos, a vila e sua estrutura produtiva caminhavam em sentido positivo. O aumento das fazendas produtivas, a diversificação da produção e a grande disponibilidade de mão-de-obra cativa indígena eram quesitos favoráveis ao maior rendimento econômico. As décadas de 1680 e 1690 foram testemunhas das mudanças ocorridas no padrão de riqueza, entretanto continuaram a expressar as mesmas desigualdades encontradas nos anos anteriores. 
Tabela 7: Distribuição dos inventários dos habitantes de Taubaté segundo as diferentes faixas de riqueza bruta (1680)

\begin{tabular}{cccccc}
\hline \multicolumn{2}{c}{ Riqueza Bruta } & \multicolumn{2}{c}{ Inventários } \\
\hline $\begin{array}{c}\text { Faixa de } \\
\text { riqueza (mil } \\
\text { réis) }\end{array}$ & $\begin{array}{c}\text { Soma dos } \\
\text { montes }\end{array}$ & $(\%)$ & $\mathbf{N}^{\mathbf{0}}$. absoluto & $(\%)$ & $\begin{array}{c}\text { Riqueza } \\
\text { Média }\end{array}$ \\
$\mathbf{0}$ a 499 & $4: 358 \$ 530$ & 20,5 & & & \\
$\mathbf{5 0 0}$ a 999 & $5: 238 \$ 030$ & 24,6 & 20 & 58,8 & $217 \$ 926$ \\
$\mathbf{1 0 0 0}$ a 1999 & $7: 744 \$ 148$ & 36,4 & - & $-20,6$ & $748 \$ 290$ \\
$\mathbf{2 0 0 0}$ a 2999 & - & - & - & 17,6 & $1: 290 \$ 691$ \\
$\mathbf{3 0 0 0}$ a 5000 & $3: 923 \$ 810$ & 18,5 & 1 & - & - \\
Mais de 5000 & - & - & - & - & $3: 923 \$ 810$ \\
Total & $21: 264 \$ 518$ & 100 & 34 & 100 & - \\
\hline
\end{tabular}

Fonte: Idem.

Tabela 8: Distribuição dos inventários dos habitantes de Taubaté segundo as diferentes faixas de riqueza bruta (1690)

\begin{tabular}{cccccc}
\hline \multicolumn{5}{c}{ Riqueza Bruta } & \multicolumn{2}{c}{ Inventários } \\
\hline $\begin{array}{c}\text { Faixa de } \\
\text { riqueza (mil } \\
\text { réis) }\end{array}$ & $\begin{array}{c}\text { Soma dos } \\
\text { montes }\end{array}$ & $\mathbf{( \% )}$ & $\mathbf{N}^{\mathbf{0}}$. absoluto & $\mathbf{( \% )}$ & $\begin{array}{c}\text { Riqueza } \\
\text { Média }\end{array}$ \\
$\mathbf{0}$ a 499 & $5: 319 \$ 660$ & 38,1 & & & \\
$\mathbf{5 0 0}$ a 999 & $3: 972 \$ 810$ & 28,4 & 24 & 72,7 & $221 \$ 652$ \\
$\mathbf{1 0 0 0}$ a 1999 & $2: 593 \$ 630$ & 18,6 & 2 & 18,2 & $662 \$ 135$ \\
$\mathbf{2 0 0 0}$ a 2999 & $2: 087 \$ 800$ & 14,9 & 1 & 6,1 & $1: 296 \$ 815$ \\
$\mathbf{3 0 0 0}$ a 5000 & - & - & - & 3,0 & $2: 087 \$ 800$ \\
Mais de 5000 & - & - & - & - & - \\
Total & $13: 973 \$ 900$ & 100 & 33 & 100 & - \\
\hline Fot & & & & & $423 \$ 451$ \\
\hline
\end{tabular}

Fonte: Idem.

Atente-se para o fato de que mais outras duas faixas de riqueza também foram atingidas, subindo com isso o índice de riqueza presente na vila. Outra característica importante vista nessas duas décadas se refere à maior divisão por níveis de riqueza da população, ou seja, mais pessoas estavam transitando entre as diferentes faixas. Apesar de ainda ser bastante visível a concentração de riqueza nas mãos de poucos, existia uma parcela da sociedade que estava se estabelecendo entre as duas pontas referenciais.

E, por fim, as duas últimas décadas, a de 1700 e a de 1710. 
Tabela 9: Distribuição dos inventários dos habitantes de Taubaté segundo as diferentes faixas de riqueza bruta (1700)

\begin{tabular}{cccccc}
\hline & \multicolumn{2}{c}{ Riqueza Bruta } & \multicolumn{2}{c}{ Inventários } \\
\hline $\begin{array}{c}\text { Faixa de } \\
\text { riqueza (mil } \\
\text { réis) }\end{array}$ & $\begin{array}{c}\text { Soma dos } \\
\text { montes }\end{array}$ & $\mathbf{( \% )}$ & $\mathbf{N}^{\mathbf{0}}$. absoluto & $(\boldsymbol{\%})$ & $\begin{array}{c}\text { Riqueza } \\
\text { Média }\end{array}$ \\
0 a 499 & $2: 080 \$ 500$ & 3,2 & & & \\
$\mathbf{5 0 0}$ a 999 & $2: 359 \$ 150$ & 3,6 & 3 & 24,2 & $260 \$ 062$ \\
$\mathbf{1 0 0 0}$ a 1999 & $15: 370 \$ 230$ & 23,2 & 10 & 9,1 & $786 \$ 383$ \\
2000 a 2999 & $19: 883 \$ 091$ & 29,9 & 8 & 24,2 & $1: 537 \$ 023$ \\
3000 a 5000 & $7: 319 \$ 510$ & 10,8 & 2 & 6,1 & $3: 659 \$ 3756$ \\
Mais de 5000 & $19: 379 \$ 128$ & 29,3 & 2 & 6,1 & $9: 689 \$ 564$ \\
Total & $66: 391 \$ 609$ & 100 & 33 & 100 & $2: 011 \$ 866$ \\
\hline
\end{tabular}

Fonte: Idem.

Tabela 10: Distribuição dos inventários dos habitantes de Taubaté segundo as diferentes faixas de riqueza bruta (1710)

\begin{tabular}{cccccc}
\hline & \multicolumn{2}{c}{ Riqueza Bruta } & \multicolumn{2}{c}{ Inventários } \\
\hline $\begin{array}{c}\text { Faixa de } \\
\text { riqueza (mil } \\
\text { réis) }\end{array}$ & $\begin{array}{c}\text { Soma dos } \\
\text { montes }\end{array}$ & $(\boldsymbol{\%})$ & $\mathbf{N}^{\mathbf{0}}$. absoluto & $(\boldsymbol{\%})$ & $\begin{array}{c}\text { Riqueza } \\
\text { Média }\end{array}$ \\
$\mathbf{0}$ a 499 & $1: 911 \$ 590$ & 1,7 & & & \\
$\mathbf{5 0 0}$ a 999 & $6: 762 \$ 710$ & 5,8 & 7 & 19,4 & $273 \$ 084$ \\
$\mathbf{1 0 0 0}$ a 1999 & $15: 464 \$ 745$ & 13,2 & 10 & 25,0 & $751 \$ 412$ \\
$\mathbf{2 0 0 0}$ a 2999 & - & - & - & - & $1: 546 \$ 474$ \\
$\mathbf{3 0 0 0}$ a 5000 & $15: 680 \$ 358$ & 13,4 & 4 & 11,1 & - \\
Mais de 5000 & $77: 007 \$ 534$ & 65,9 & 6 & 16,7 & $12: 834 \$ 589$ \\
Total & $116: 826 \$ 937$ & 100 & 36 & 100 & $3: 245 \$ 192$ \\
\hline
\end{tabular}

Fonte: Idem.

São duas décadas inteiramente diferenciadas no conjunto da pesquisa. Como se viu ao longo de todas as tabelas e quadros expostos na presente dissertação, fortes mudanças ocorreram neste espaço de tempo, e elas estavam diretamente ligadas à relação estabelecida entre a vila e a nova região mineira da colônia.

Mais uma vez, a desigualdade na distribuição da riqueza é evidente. Na década de 1700, o percentual de 6,1\% dos inventários detém 29,3\% da riqueza total da vila. No período seguinte, os números são ainda mais discrepantes. Cerca de $16,7 \%$ da população possuía, nada menos, do que $65,9 \%$ da riqueza bruta, ou seja, mais da metade do poder econômico de Taubaté estava nas mãos de uma minoria. Além do que, vê-se que a faixa estabelecida como a mais rica dentre todas foi atingida. Tal realidade incita a pensar numa abertura de possibilidades econômicas, papel este reconhecidamente exercido pelas Minas, 
e que disponibilizou oportunidades de aquisição de riqueza não somente a uma parcela populacional prioritária. Foram muitas as pessoas que se viram diante das mudanças no padrão econômico familiar. A injeção de ouro e a abertura de novos mercados consumidores favoreceram direta e indiretamente a todos que viviam na vila e que passaram a ter, agora, maiores chances de retorno financeiro positivo.

Após observar todas estas tabelas, seria um erro pensar em "democracia econômica" num período onde a desigualdade na distribuição da riqueza era a regra. Assim, não se pode dizer que havia "uma riqueza bem distribuída", como pensa José Bernardo Ortiz. De forma bem enfática, este trabalho, seguindo nas linhas propostas por Maurício Martins Alves, também defende que "longe de igualitária, a sociedade taubateana foi marcada por profundas desigualdades na distribuição da riqueza." 290

Além das desigualdades na distribuição da riqueza, outras informações também puderam ser extraídas das fontes. Foi possível verificar os setores econômicos de maior interesse indicados pelos conjuntos de pessoas localizadas nas diferentes faixas de riquezas definidas. Já foi apresentada uma tabela que expôs a divisão da riqueza local depositada em diferentes setores, e esta permitiu uma visão ampliada da economia da vila. Mas, agora, pretende-se aprofundar um pouco mais a análise. Separar grupos sociais via condição econômica vivida por eles ajuda a estabelecer padrões diferenciados no que diz respeito aos seus respectivos interesses.

Se por um lado foi comprovada a existência de uma desigualdade crônica na sociedade taubateana, desigualdade esta que pode estar ligada às poucas oportunidades de empreendimento oferecidas num dado momento e, depois, à ampliação do campo comercial oriundo das novas fronteiras de exploração mineira, por outro, ainda é preciso discorrer sobre os interesses de cada grupo social, dessa forma será possível enxergar se havia ou não diferenças nos setores de maior ou menor investimento entre os mais ricos e os mais pobres.

Como de praxe, as tabelas estão divididas por décadas.

\footnotetext{
${ }^{290}$ ALVES, Maurício Martins. Op. cit. p.50.
} 
Tabela 11: Percentual da riqueza bruta da vila de Taubaté imobilizada em cada tipo de setor segundo faixa de riqueza (1650)

\begin{tabular}{lcccccc}
\hline & \multicolumn{6}{c}{ Faixa de Riqueza Bruta (em mil réis) } \\
\hline Setor & $\mathbf{0 ~ a}$ & $\mathbf{5 0 0}$ a & $\mathbf{1 0 0 0}$ a & $\mathbf{2 0 0 0}$ a & $\mathbf{3 0 0 0}$ a & Mais de \\
& $\mathbf{4 9 9}$ & $\mathbf{9 9 9}$ & $\mathbf{1 9 9 9}$ & $\mathbf{2 9 9 9}$ & $\mathbf{5 0 0 0}$ & $\mathbf{5 0 0 0}$ \\
Rural & 8,0 & 7,0 & 3,7 & - & - & - \\
Urbano & 0,4 & 0,2 & 0,5 & - & - & - \\
Escravo & 75,0 & 85,8 & 88,9 & - & - & - \\
Ouro & - & 0,4 & - & - & - & - \\
Prata & - & 0,1 & 0,4 & - & - & - \\
Comércio & 5,0 & - & - & - & - & - \\
P. Vida & 3,9 & 4,3 & 4,1 & - & - & - \\
Sertanismo & 0,6 & 0,7 & 0,8 & - & - & - \\
D. Ativa & 7,1 & 1,5 & 1,6 & - & - & - \\
D. Passiva & 34,9 & 2,1 & 5,3 & - & - & - \\
\hline
\end{tabular}

Fonte: Inventários (1649 a 1720). Arquivo Histórico Municipal de Taubaté.

Tabela 12: Percentual da riqueza bruta da vila de Taubaté imobilizada em cada tipo de setor segundo faixa de riqueza (1660)

\begin{tabular}{lcccccc}
\hline & \multicolumn{6}{c}{ Faixa de Riqueza Bruta (em mil réis) } \\
\hline Setor & $\mathbf{0 ~ a}$ & $\mathbf{5 0 0}$ a & $\mathbf{1 0 0 0}$ a & $\mathbf{2 0 0 0}$ a & $\mathbf{3 0 0 0}$ a & Mais de \\
& $\mathbf{4 9 9}$ & $\mathbf{9 9 9}$ & $\mathbf{1 9 9 9}$ & $\mathbf{2 9 9 9}$ & $\mathbf{5 0 0 0}$ & $\mathbf{5 0 0 0}$ \\
Rural & 5,2 & - & 7,2 & - & - & - \\
Urbano & 0,9 & - & 1,2 & - & - & - \\
Escravo & 72,8 & 86,1 & 57,7 & - & - & - \\
Ouro & 1,9 & - & 0,7 & - & - & - \\
Prata & 1,4 & 2,4 & 1,5 & - & - & - \\
Comércio & - & - & - & - & - & - \\
P. Vida & 10,8 & 11,5 & 4,5 & - & - & - \\
Sertanismo & 1,3 & - & 5,7 & - & - & - \\
D. Ativa & 5,7 & - & 21,5 & - & - & - \\
D. Passiva & 7,7 & - & 10,5 & - & - & - \\
\hline
\end{tabular}

Fonte: Idem.

${ }^{291}$ Lembrar que os valores aqui expostos correspondem ao cálculo obtido sobre o monte-mor, já que eles serão o percentual de subtração do total. Por exemplo: $34,87 \%$ é o valor que o monte-mor está comprometido a pagar, ou seja, é o percentual que será subtraído dele. 
Tabela 13: Percentual da riqueza bruta da vila de Taubaté imobilizada em cada tipo de setor segundo faixa de riqueza (1670)

\begin{tabular}{lcccccc}
\hline & \multicolumn{6}{c}{ Faixa de Riqueza Bruta (em mil réis) } \\
\hline Setor & $\mathbf{0}$ a & $\mathbf{5 0 0}$ a & $\mathbf{1 0 0 0}$ a & $\mathbf{2 0 0 0}$ a & $\mathbf{3 0 0 0}$ a & Mais de \\
& $\mathbf{4 9 9}$ & $\mathbf{9 9 9}$ & $\mathbf{1 9 9 9}$ & $\mathbf{2 9 9 9}$ & $\mathbf{5 0 0 0}$ & $\mathbf{5 0 0 0}$ \\
Rural & 7,7 & - & 5,3 & - & - & - \\
Urbano & 2,0 & - & 0,7 & - & - & - \\
Escravo & 79,0 & - & 90,2 & - & - & - \\
Ouro & 0,2 & - & - & - & - & - \\
Prata & 0,3 & - & 0,4 & - & - & - \\
Comércio & - & - & - & - & - & - \\
P. Vida & 5,4 & - & 0,7 & - & - & - \\
Sertanismo & 1,2 & - & 1,9 & - & - & - \\
D. Ativa & 4,2 & - & 0,8 & - & - & - \\
D. Passiva & 30,2 & - & 2,1 & - & - & - \\
\hline
\end{tabular}

Fonte: Idem.

Como ponto em comum entre os diferentes níveis sociais, o depósito de grande parte da riqueza em escravos não só era a preferência durante todo o período como também parece ser o mais seguro de todos os itens. Não se pode esquecer de que se está falando de uma sociedade escravista. A riqueza depositada na mão-de-obra cativa chega a comprometer altas porcentagens, ficando entre $57,7 \%$ e $88,9 \%$. Definitivamente, a população de forma geral estava em consonância em relação à importância atribuída à propriedade de cativos. Logicamente que numa sociedade escravocrata, a posse deles era um quesito básico para a sustentação estamental, mas, além disso, as "peças" escravas compunham um setor muito seguro para os investimentos porque gerava retorno financeiro, seja em primeira instância como meio para suprir a subsistência (força de trabalho), seja em seguida como via de maiores lucratividades (compra e venda). O próprio comércio de escravos, em paralelo à grande demanda por mão-de-obra, fazia com que seus donos se sentissem seguros quanto à manutenção relativa do valor empregado. Estende-se tal raciocínio tanto aos índios quanto aos negros africanos.

Muito atrás do item escravo, estão o setor rural, dívidas ativas, dívidas passivas e padrão de vida, não necessariamente nesta ordem.

$\mathrm{O}$ percentual referente às propriedades rurais é relativamente baixo, variando de $3,7 \%$ a $8,0 \%$, mas isso não quer dizer que tal setor seja de pouco interesse, ao contrário, era a área produtiva, onde trabalhava a grande maioria daquela população escrava. Sabe-se que as terras em si não tinham tanto valor monetário, pois como a região participava ainda de 
um período de ocupação, boa parte da área estava à disposição dos que chegavam. ${ }^{292}$ No entanto, o que a tornava valiosa eram os mecanismos produtivos instalados como, por exemplo, os maquinários, as plantações, os animais e, principalmente, a mão-de-obra escrava. Assim, é preciso observar a ligação existente entre o campo - representado pelo item "rural" - e os trabalhadores escravos como a essência que formava a base da economia local.

Em seguida, há as dívidas ativas e passivas. Como já foi salientado, o exercício delas era determinante para o funcionamento da economia não só local, mas em todo o universo colonial. Ora, eram muitas as motivações que levavam as pessoas a contraí-las: as necessidades de recursos para iniciar um negócio e/ou a sustentação de um padrão de vida estavam entre as causas mais comuns. É muito difícil saber exatamente os motivos de cada grupo social, mas tentar-se-á fazer algumas notas. Porém, antes, há que se ter noção de que o envolvimento com as dívidas era quase inevitável já que elas tinham imensa participação dentro dos mecanismos de funcionamento da economia. Se na maioria dos casos a aquisição de dívidas fazia parte da própria dinâmica da sobrevivência em sociedade, houve casos em que a manipulação dos empréstimos parecia ser um negócio. Por exemplo, no inventário de Sebastiana de Unhate, datado de 16 de abril de 1703, o viúvo, Jorge Dias Velho, declarou ter 4:547\$293 réis em "dinheiro amoedado" nas mãos de muitas pessoas através de empréstimos a juros. Esse valor correspondia a 32,5\% de toda a riqueza da família, sem contar os juros que irá receber. ${ }^{293}$ Outro que também pode ter visto nesta prática uma oportunidade de negócio foi o Capitão Domingos Rodrigues do Prado, inventariado em 1715. Consta em seu documento um rol de dívidas ativas, isto é, "que devem a fazenda", onde se vê a circulação de muito ouro em pó através dos empréstimos,

\footnotetext{
${ }^{292}$ A abundância de terras teria sido o principal motivo para o seu baixo valor, além do que, era possível obtê-las através das doações em forma de sesmaria e datas de terras. Todavia, a posse de extensas áreas significava uma mudança no estatuto social, ou seja, as terras não tinham tanto valor monetário e sim grande valor simbólico. Maranho acredita "que a importância em ser proprietário não estava relacionada ao valor da terra concedida, mas sim ao significado da própria concessão, dada apenas 'aos mais antigos da terra', filhos e netos de povoadores. (...) Portanto, afirmar que a terra não possuía valor monetário é correto, contudo um outro valor era atribuído à sua posse: o valor social que possibilitava, junto às boas relações e a ostentação, a aquisição de posições de destaque." MARANHO, Milena Fernandes. A Opulência Relativizada: significados econômicos e sociais dos níveis de vida dos habitantes da região do Planalto de Piratininga (1648-1682). Dissertação de Mestrado: Unicamp, 2000. p.179.

${ }^{293}$ Inventário de Sebastiana de Unhate (1703). Cx: 1700-1703. A.H.M.T.
} 
tudo na forma de "créditos tomados sob juros." 294 Somando a quantia de 5:138\$790 réis, tais empréstimos equivaliam a $48,7 \%$ do monte-mor avaliado. Esse grande comprometimento sugere não apenas uma intensionalidade no exercício dos empréstimos nestes casos, é claro - mas também a existência de um negócio lucrativo visto que eram quase sempre feitos sob juros, sendo assim, uma fonte de renda. Portanto, involuntariamente ou não, grande parcela da população recorria a esta importante ferramenta.

Voltando aos dados encontrados, observa-se, em primeiro lugar, que todas as faixas sociais as praticavam, o que variava eram as equivalências delas em relação à riqueza total, isto é, enquanto que alguns eram mais devedores, outros eram credores. Engana-se quem pensa que eram os pobres os que mais deviam, os mais ricos também costumavam dever muito. Essa situação mudava com o tempo. Na década de 1650, aparece o grupo menos abastado como sendo devedor de $34,9 \%$ de toda sua riqueza, enquanto que na década seguinte, tal débito cai para 7,7\% para voltar a subir em 1670 à taxa de 30,2\%. Já o grupo mais rico, começou devendo 5,3\%, depois subiu para 10,5\%, para cair em seguida ao ponto de atingir $2,1 \%$.

Seria desgastante demais discorrer sobre todas as flutuações nas porcentagens de comprometimento das dívidas de cada grupo em questão. Reconhece-se a importância e necessidade de um estudo minucioso sobre isso, mas não há espaço aqui para demasiada discussão.

Importa constatar que as possibilidades de obtenção de crédito estavam disponíveis em todos os níveis econômico-sociais. Desde os mais pobres até os mais ricos, todos tinham acesso aos mecanismos que movimentavam tais transações, seja entre os seus próprios pares ou mesmo entre os diferentes níveis sociais. Aliás, era muito comum o uso do crédito como forma de manter relações sociais com fins políticos e, mesmo, como fortalecimento de clãs. ${ }^{295}$

As tabelas das décadas seguintes apresentam, de maneira geral, dados muito parecidos, mas alguns comentários podem ser feitos.

\footnotetext{
${ }^{294}$ Inventário do Capitão Domingos Rodrigues do Prado (1715). Cx: 1709-1715. A.H.M.T.

${ }^{295}$ Cf. MARANHO, Milena Fernandes. Op. cit.
} 
Tabela 14: Percentual da riqueza bruta da vila de Taubaté imobilizada em cada tipo de setor segundo faixa de riqueza (1680)

\begin{tabular}{lcccccc}
\hline & \multicolumn{5}{c}{ Faixa de Riqueza Bruta (em réis) } \\
\hline Setor & $\mathbf{0 ~ a ~}$ & $\mathbf{5 0 0}$ a & $\mathbf{1 0 0 0}$ a & $\mathbf{2 0 0 0}$ a & $\mathbf{3 0 0 0}$ a & Mais de \\
& $\mathbf{4 9 9}$ & $\mathbf{9 9 9}$ & $\mathbf{1 9 9 9}$ & $\mathbf{2 9 9 9}$ & $\mathbf{5 0 0 0}$ & $\mathbf{5 0 0 0}$ \\
Rural & 7,2 & 9,5 & 5,6 & - & 2,5 & - \\
Urbano & 1,9 & 1,0 & 1,2 & - & 0,8 & - \\
Escravo & 76,2 & 76,7 & 71,3 & - & 90,8 & - \\
Ouro & 1,1 & 0,1 & 0,2 & - & 0,2 & - \\
Prata & 0,4 & 0,3 & 0,3 & - & 0,5 & - \\
Comércio & 0,2 & 0,8 & 1,4 & - & 2,2 & - \\
P. Vida & 3,2 & 3,2 & 2,0 & - & 1,1 & - \\
Sertanismo & 0,7 & 1,7 & 0,6 & - & 0,4 & - \\
D. Ativa & 9,1 & 6,7 & 17,4 & - & 1,5 & - \\
D. Passiva & 9,2 & 17,1 & 24,0 & - & 12,2 & - \\
\hline
\end{tabular}

Fonte: Inventários (1649 a 1720). Arquivo Histórico Municipal de Taubaté.

Nesta década, verifica-se o avanço social nas faixas econômicas pré-estabelecidas, isso ocorre devido à evolução produtiva da vila. Continuam sendo os escravos os elementos de maior valor na sociedade, seguido pelo setor rural. As dívidas também continuam ocupando bastante espaço no conjunto da riqueza de todos os níveis da população.

Os anos seguintes seguem as tendências de mudanças no quadro da riqueza local em função das descobertas auríferas que, como já foi muitas vezes falado, favoreceram o enriquecimento da vila por meio da injeção de ouro e aquecimento da produção destina ao comércio.

Tabela 15: Percentual da riqueza bruta da vila de Taubaté imobilizada em cada tipo de setor segundo faixa de riqueza (1690)

\begin{tabular}{lcccccc}
\hline & \multicolumn{7}{c}{ Faixa de Riqueza Bruta (em réis) } \\
\hline Setor & $\mathbf{0 ~ a}$ & $\mathbf{5 0 0}$ a & $\mathbf{1 0 0 0}$ a & $\mathbf{2 0 0 0}$ a & $\mathbf{3 0 0 0}$ a & Mais de \\
& $\mathbf{4 9 9}$ & $\mathbf{9 9 9}$ & $\mathbf{1 9 9 9}$ & $\mathbf{2 9 9 9}$ & $\mathbf{5 0 0 0}$ & $\mathbf{5 0 0 0}$ \\
Rural & 13,5 & 8,7 & 12,6 & 1,4 & - & - \\
Urbano & 2,6 & 1,4 & 8,0 & 7,2 & - & - \\
Escravo & 66,3 & 66,6 & 70,6 & 37,4 & - & - \\
Ouro & 0,1 & 0,4 & - & 2,2 & - & - \\
Prata & 0,7 & 1,4 & 1,5 & 1,6 & - & - \\
Comércio & 1,6 & 1,2 & 0,4 & - & - & - \\
P. Vida & 5,0 & 6,9 & 4,2 & 43,0 & - & - \\
Sertanismo & 2,5 & 1,8 & 0,7 & 7,2 & - & - \\
D. Ativa & 7,7 & 11,6 & 2,0 & - & - & - \\
D. Passiva & 8,6 & 11,5 & 15,6 & 19,6 & - & - \\
\hline Fonte: Idem & & \multicolumn{7}{c}{. }
\end{tabular}

Fonte: Idem. 
Tabela 16: Percentual da riqueza bruta da vila de Taubaté imobilizada em cada tipo de setor segundo faixa de riqueza (1700)

\begin{tabular}{lcccccc}
\hline & \multicolumn{6}{c}{ Faixa de Riqueza Bruta (em réis) } \\
\hline Setor & $\mathbf{0 a}$ & $\mathbf{5 0 0} \mathbf{a}$ & $\mathbf{1 0 0 0} \mathbf{a}$ & $\mathbf{2 0 0 0} \mathbf{a}$ & $\mathbf{3 0 0 0} \mathbf{a}$ & Mais de \\
& $\mathbf{4 9 9}$ & $\mathbf{9 9 9}$ & $\mathbf{1 9 9 9}$ & $\mathbf{2 9 9 9}$ & $\mathbf{5 0 0 0}$ & $\mathbf{5 0 0 0}$ \\
Rural & 4,4 & 7,0 & 10,4 & 10,0 & 7,1 & 4,5 \\
Urbano & 1,5 & - & 3,5 & 1,4 & 2,7 & 2,9 \\
Escravo & 52,2 & 86,9 & 52,3 & 64,6 & 78,5 & 53,6 \\
Ouro & 5,2 & - & 13,0 & 10,8 & 2,2 & 6,5 \\
Prata & 0,2 & 0,6 & 0,7 & 0,5 & 4,2 & 1,6 \\
Comércio & 1,7 & - & 2,3 & 1,0 & - & 0,5 \\
P. Vida & 4,9 & 2,5 & 5,9 & 3,5 & 1,6 & 4,0 \\
Sertanismo & 2,5 & 0,4 & 1,5 & 0,7 & 1,5 & 0,7 \\
D. Ativa & 27,4 & 2,6 & 10,4 & 7,5 & 2,2 & 25,7 \\
D. Passiva & 45,2 & 5,9 & 37,2 & 11,8 & 3,3 & 6,7 \\
\hline
\end{tabular}

Fonte: Idem.

Tabela 17: Percentual da riqueza bruta da vila de Taubaté imobilizada em cada tipo de setor segundo faixa de riqueza (1710)

\begin{tabular}{lcccccc}
\hline & \multicolumn{5}{c}{ Faixa de Riqueza Bruta (em réis) } \\
\hline Setor & $\mathbf{0 ~ a}$ & $\mathbf{5 0 0} \mathbf{a}$ & $\mathbf{1 0 0 0} \mathbf{a}$ & $\mathbf{2 0 0 0} \mathbf{a}$ & $\mathbf{3 0 0 0} \mathbf{a}$ & Mais de \\
& $\mathbf{4 9 9}$ & $\mathbf{9 9 9}$ & $\mathbf{1 9 9 9}$ & $\mathbf{2 9 9 9}$ & $\mathbf{5 0 0 0}$ & $\mathbf{5 0 0 0}$ \\
Rural & 8,4 & 15,2 & 6,2 & - & 11,6 & 5,2 \\
Urbano & - & 2,9 & 2,5 & - & 2,6 & 1,9 \\
Escravo & 69,6 & 67,4 & 68,0 & - & 40,6 & 29,2 \\
Ouro & - & 0,3 & 0,8 & - & 0,8 & 36,8 \\
Prata & 0,8 & 1,6 & 0,3 & - & 0,8 & 0,4 \\
Comércio & - & 1,1 & - & - & 12,8 & 4,0 \\
P. Vida & 2,3 & 4,0 & 5,6 & - & 5,4 & 2,2 \\
Sertanismo & 0,9 & 1,2 & 0,8 & - & 0,4 & 0,1 \\
D. Ativa & 18,0 & 6,3 & 15,8 & - & 25,0 & 20,2 \\
D. Passiva & 8,2 & 21,7 & 14,7 & - & 44,0 & 11,4 \\
\hline
\end{tabular}

Fonte: Idem.

Como representativo de uma nova conjuntura, os dados acima também trazem novidades. Os números referentes a década de 1690 aparentam não ter alterações quanto aos períodos anteriores. Todavia, atente-se para a faixa de maior riqueza. Neste setor, é a primeira vez que a maior parcela de riqueza não está depositada nos escravos, mas sim no padrão de vida. Tem-se também a valorização do setor urbano que, aos poucos, ganha espaço no conjunto da riqueza da vila. 
Na década de 1700 todas as faixas de riqueza estão preenchidas, o que denota o enriquecimento da vila. ${ }^{296}$ Volta-se a ter a maioria da riqueza representada pelos escravos que, ligados ao setor rural, completavam o sistema produtivo básico da vila. Como de costume, as porcentagens de comprometimento com as dívidas ativas e passivas também são altas. Neste dado momento, a presença de liquidez via ouro e prata é quesito fundamental para o crescimento dos empréstimos, tornando-os um ramo muito lucrativo no sistema comercial da colônia. Há um impulso na mercantilização da economia de Taubaté e tal mudança atinge todos os setores, cada qual com o seu relativo peso, como se observa nas informações referentes à distribuição de ouro e prata.

E, por último, a década de 1710. O destaque aqui fica por conta da forte concentração de ouro nas mãos de uma pequena parcela da população. Se na década anterior havia uma melhor distribuição do metal, agora o quadro é de total desigualdade. A faixa mais rica detém nada menos que $36,8 \%$ da sua riqueza depositada no ouro, superando inclusive o item "escravo". A posse de tanta liquidez disponibilizava recursos que viabilizavam as transações que envolviam os empréstimos, mais ativos do que passivos, o que leva a crer na consolidação destas atividades como práticas muito lucrativas e de bastante flexibilidade, mas não disponíveis em grande proporção a toda a sociedade. Existiam os pequenos e grandes empréstimos, com variações devido as suas finalidades. Poderiam ter sido utilizados apenas como meio para obtenção de recursos para a sustentação de uma produção voltada à subsistência familiar, ou poderiam também ser destinados à implantação ou ampliação de alguma grande produção com fins comerciais, ou mesmo como uma forma de participação em empresas sertanistas, e até como meio de reutilização em novos empréstimos. Enfim, a circulação de liquidez através de atividades comerciais era uma realidade que cada nível social vivenciava à sua maneira, uns sendo

\footnotetext{
${ }^{296}$ É preciso ressaltar que a elevação dos números, isto é, dos níveis de riqueza, apresetados se deve não apenas a injeção de riquezas na vila, mas também devido ao efeito inflacionário ocorrido com a abundância de ouro e com a crise de abastecimento que atingiu muitas regiões do Brasil. Sobre o custo de vida na zona mineira observa Antonil: "Estes preços, tão altos e tão correntes nas minas, foram causa de subirem tanto os preços de todas as cousas, como se experimenta nos portos das cidades e vilas do Brasil, e de ficarem desfornecidos muitos engenhos de açúcar das peças necessárias e de padecerem os moradores grande carestia de mantimentos, por se levarem quase todos aonde vendidos hão de dar maior lucro.” ANTONIL, André João. Cultura e Opulência do Brasil. 3ª Ed. São Paulo: Editora da Universidade de São Paulo, 1982. p. 171. Vale consultar a lista de preços dos produtos feita pelo jesuíta que se encontra na mesma obra e página.
} 
mais prejudicados, outros mais favorecidos, alargando ainda mais as divisões sócioeconômicas existentes na vila.

Em termos sociais e econômicos, Taubaté configurava-se enquanto uma vila fortemente desigual. O posicionamento dos indivíduos na sociedade variava conforme suas posses, mas isso não era tudo, havia a participação nos meios de comando político que também davam àqueles que nele estavam status bastante considerável. E acrescente-se a posse de patentes militares como meio de distinção. A participação na Câmara municipal e no corpo militar local será discutida a partir de agora.

\subsection{Cargos Públicos: a câmara municipal e as ordenanças militares}

A vida colonial do Brasil tem lá as suas especificidades muito interessantes e, por isso mesmo, peculiares para quem observa de longe - no tempo - e bastante comuns para aqueles que participavam deste antigo ambiente histórico. Em termos de comportamento social as regras escravistas e estamentais ditavam a dinâmica das relações entre as pessoas de diferentes posições e, não em menor intensidade, entre seus pares.

Sem dúvida alguma, como demonstrado até aqui, critérios econômicos eram fundamentais para a consolidação da desigualdade existente na população. No entanto, não obstante o considerável peso financeiro exercido na balança como determinante do posicionamento social, outros caprichos também podiam ter suas influências como, por exemplo, o exercício de cargos públicos e a posse de patentes militares. Enfim, “o primeiro sinal de distinção social era o estatuto de homem livre e, em seguida, o de proprietário de terras e de escravos". Soma-se a estes, complementando o que diz Ilana Blaj, a participação na vida política e militar da vila como quesitos carregados com valores capazes de oferecer distinção e prestígio. ${ }^{297}$

Pensando nisso, procurou-se fazer algumas considerações sobre as características políticas e militares da vila de Taubaté, dando ênfase ao que se pôde coletar na documentação disponível. Aliás, como não se tem notícia da existência das Atas da Câmara e, muito menos, de alguma lista das ordenanças e milícias locais, todas as informações foram extraídas dos inventários e testamentos. Com certeza, tais documentos têm suas limitações no tocante a assuntos como política e organização militar; porém, a investigação

${ }^{297}$ BLAJ, Ilana. Op. cit. p. 326. 
de um pesquisador não pode ser barrada pela falta de fontes diretas. Ao contrário, é desejável a utilização de fontes paralelas a fim de ampliar o escopo da análise.

Taubaté foi elevada à categoria de vila em 5 de dezembro de 1645 e as atividades camarárias tiveram inicio em janeiro do ano seguinte. Ela foi a primeira vila da região do vale do Paraíba, tornando-se assim a referência do poder local. Sua enorme extensão territorial e, conseqüentemente, jurisdicional é testemunha disso:

o Termo da vila de Taubaté (município), citado em documentos do século XVII, correspondia às terras do curso alto e de grande parte do curso médio do rio Paraíba. Seu limite setentrional atingia, aproximadamente, os cômoros da Mantiqueira, enquanto que ao Sul se estendia às cumeadas externas da serra do Mar, a cerca de duas léguas do oceano, limitando uma faixa alongada que variava de cinqüenta a cem quilômetros de largura. A ocidente, o Termo da Taubaté tinha início aproximado na atual linha limítrofe entre os municípios de São José dos Campos e Caçapava prolongada de uma a outra serra, e para leste, se alongava na direção dos extremos do atual fundo paulista do vale, até limite incerto, nas terras dos atuais municípios de Queluz e Areias, numa extensão de cerca de cento e cinqüenta quilômetros e encerrando um quadrilátero de mais de oito mil quilômetros quadrados. ${ }^{298}$

Logicamente que dentro desta área houve outras povoações que, ao longo de tempo, também foram se tornando vilas. Mesmo assim, a vila taubateana ainda possuía o posto de núcleo do poder regional, isto talvez não só pelo seu caráter pioneiro, mas também pela sua localização geográfica, que lhe conferia um papel central na convergência da rotas terrestres que cortavam o vale do Paraíba.

Reconhecidamente, a Câmara era peça fundamental para o bom exercício do governo em termos locais. Por isso mesmo, cabe aqui uma descrição rápida dos cargos existentes e suas atribuições. Vale lembrar que a teoria normalmente não se materializava na prática, isto é, as multiplas realidades que compunham o Império português refletiam na própria organização dos sistemas governativos, isso significa que era comum as Câmaras municipais apresentarem números diferentes de membros, de cargos e, às vezes, de funções.

Basicamente, sua composição para a época estudada era a seguinte:

Juiz Ordinário - variando entre um ou dois eram eleitos trienamente para servir durante um ano. Apesar da pouca distinção que havia entre suas funções judiciais e

${ }^{298}$ ORTIZ, José Bernardo. São Francisco das Chagas de Taubaté. Tomo I. Taubaté: Prefeitura Municipal, 1996. p. 107-108. 
administrativas, era responsável pela aplicação da justiça - em cárater limitado ${ }^{299}$-, pela viabililização das decisões, pela manutenção de um direito local entre vizinhos e, quando preciso, exercia as funções do juiz dos órfãos;

Juiz dos Órfãos - provido pelo rei durante o período de três anos. Cabia a ele zelar pelos órfãos, principalmente no que diz respeito aos seus bens e rendas, inventariar a fazenda dos defuntos que deixassem filhos menores que vinte e cinco anos e fiscalizar a atuação dos tutores e curadores em relação aos bens dos órfãos;

Juiz de Fora - provido pelo rei, este cargo foi criado em 1696. Tinha praticamento as mesmas funções que o juiz ordinário, diferenciando-se apenas por ser um fiscal vindo de fora, a mando da metrópole ${ }^{300}$;

Vereadores - no número de dois ou três eram eleitos trienalmente para servir durante o período de um ano. Deveriam opinar sobre as contribuições, arrendamentos, doações e quitações, além de zelar pelos bens do conselho e tomar parte nas decisões de governo da cidade ou vila, visando sempre o "bem viver" dos moradores;

Procurador - eleito trienalmente, representava os interesses do conselho ou da coletividade em questões judiciais, sendo o equivalente a um promotor público. Deveria vistoriar o estado de conservação das casas, o aproveitamento das fontes, chafarizes, pontes, poços e calçadas, encaminhando solicitações à Câmara em caso de se encontrarem danos, requerendo os devidos reparos;

Almotacé - em número de um ou dois, eram eleitos mensalmente pela Câmara para fiscalizar o abastecimento de víveres para a localidade, fazer cumprir os preços estabelecidos pelo governo local, averiguar as medidas de comprimento e peso, observar a execução das posturas municipais referentes à disposição dos prédios e ordenação das ruas, além de zelar pela limpeza da vila ou cidade;

Escrivão - nomeado pela Câmara, era responsável por registrar todas as atividades por ela exercidas;

\footnotetext{
${ }^{299}$ Segundo o título LXV do livro I das Ordenações Filipinas, o juiz ordinário de um conselho com mais de sessenta vizinhos tinha alçada sem apelação nem agravo até a quantia de mil réis em causas envolvendo bens móveis. Caso tivesse menos de sessenta vizinhos, julgava em causas de até seiscentos réis. Já nas causas que envolviam bens imóveis sua alçada não ultrapassava quatrocentos réis.

${ }^{300}$ Registra-se desde já que, ao que tudo indica, Taubaté não abrigou este funcionário, pelo menos dentro do recorte cronológico da presente dissertação.
} 
Tesoureiro - eleito trienalmente, era responsável pelos trâmites e controles financeiros do órgão;

Além destes havia os cargos auxiliares como: porteiro, vedor de obras, corretor, sacador, pregoeiro, provedor de hospitais, etc.

Apesar de cada um ter a sua função específica era comum que, levando-se em consideração o tamanho da vila ou cidade governada, houvesse acúmulo de atribuições, fazendo com que variasse o número de cargos. No caso de Taubaté, foi possível identificar apenas a presença de um juiz ordinário (que também exercia a função de juiz dos órfãos), três vereadores, um procurador, um almotacé e um escrivão. Quanto aos outros cargos a documentação disponível não permitiu tomar conhecimento.

Considerando a importância político-administrativa que a Câmara municipal exercia no Brasil, assim como em todas as possessões portuguesas, ${ }^{301}$ a participação em suas decisões dava automaticamente aos seus membros um elevado grau de status social que se estendia não apenas ao membro propriamente dito, mas também aos seus herdeiros legítimos, condição muitas vezes exigida para o exercício de algum cargo público. Na verdade, o que se tem aqui é a formação de um grupo privilegiado que, de uma forma ou de outra, monopolizava os mecanismos das decisões políticas. Por exemplo, o direito de distribuição de terras, as chamadas "cartas de datas", ou mesmo o auxílio na obtenção de sesmarias era uma das maneiras de engrandecimento do grupo ligado ao poder local; assim, prestígio social, posse de terras e riqueza se auto-reproduziam no interior de uma dada parcela da sociedade, renovando-se ao longo dos tempos. ${ }^{302}$ De maneira geral,

(...) não são apenas os ganhos materiais o que de melhor o poder municipal oferecia àqueles que se encontravam habilitados para exercêlos. Os ganhos são políticos e também de prestígio. Existia a idéia de que os cargos políticos eram nobilitadores e, por isso, eles são desejados. $O$ anseio pela manutenção ou elevação de status quo estava envolvido, pois,

\footnotetext{
301 "Elementos de unidade e de continuidade entre o Reino e seus domínios, pilares da sociedade colonial portuguesa nos quatro cantos do mundo, as Câmaras Municipais Ultramarinas foram órgãos fundamentais de representação dos interesses e das demandas dos colonos." BICALHO, Maria Fernanda Baptista. "As Câmaras Municipais no Império Português: o exemplo do Rio de Janeiro." Revista Brasileira de História. São Paulo: ANPUH/ Humanitas Publicações, Vol. 18, n.36, 1998. p. 252.

302 "A Câmara também tinha um papel importante na distribuição de sesmarias, ficando encarregada em definir quais solicitantes estavam aptos a receber as terras pedidas." CÂMARA, Leandro Calbente. Administração Colonial e Poder: a governança da cidade de São Paulo (1765-1802). Dissertação de Mestrado: FFLCH/USP, 2008. p. 108.
} 
na estratégia de controlar o acesso a esses cargos ou, nas tentativas de acessá-los. ${ }^{303}$

Já que a ligação com os veículos de dominação da política local elevava a condição social daqueles que estavam neste meio, enganam-se os estudiosos que acreditam no exercício de uma "democracia”. Tal erro baseia-se na ânsia de estender à prática aquilo que se encontrava na teoria, ou mesmo num erro de interpretação. Os irmãos Tito Lívio Ferreira e Manoel Rodrigues Ferreira, por exemplo, acreditam que "os moradores do Brasil adquiriram pois, o hábito democrático de escolher por meio de eleições (...)" ${ }^{304}$ Tem-se a impressão de que tais autores levaram "ao pé da letra" o termo eleição e se esqueceram que isto não significava democracia, isto é, o sistema de escolha dos oficiais públicos poderia ser feito via eleição, mas é preciso lembrar que havia restrições que limitavam em muito a população que detinha o direito de voto. ${ }^{305} \mathrm{O}$ próprio sistema de pelouros, como era denominada tal eleição, “(...) permitia que um grupo pequeno de elementos controlassem os cargos do conselho e, portanto, não eram numerosos os que 'andavam na governança' de cada terra." 306

${ }^{303}$ SOUZA, George Félix Cabral de. Os Homens e os Modos da Governança: a Câmara Municipal do Recife do século XVIII num fragmento da história das instituições municipais do Império Colonial Português. Dissertação de Mestrado: Universidade Federal de Pernambuco, 2002. p. 54.

${ }^{304}$ FERREIRA, Tito Lívio; FERREIRA, Manoel Rodrigues. História da Civilização Brasileira. São Paulo: Editora Gráfica Biblos, 1959. p. 136.

${ }^{305}$ Seria um anacronismo intitular o sistema de escolha dos membros da Câmara municipal de "democrático" tomando como parâmetro de análise o simples fato de que uma pequena parcela da população tinha o direito a tal. Considerando que democracia significa a existência de um governo em que o povo exerce a soberania, onde as ações políticas são voltadas para atender os interesses populares e as decisões são tomadas, não de forma ocasional ou circunstancial, mas segundo princípios permanentes de legalidade, e, é claro, o comprometimento do sistema político com a igualdade ou com a distribuição equitativa de poder entre todos os cidadãos, fica impossível aplicar tal rótulo ao período colonial da história do Brasil no qual era regido por um sistema monárquico absolutista, sem falar na sociedade que era organizada sob os valores estamentais e escravistas. Para uma melhor compreensão das características históricas da cultura política e jurídica brasileira, recomenda-se a leitura de uma coletânia de artigos, recentemente publicada, onde são abordados diferentes temas ao longo de toda a História do Brasil. Cf. LARA, Silvia Hunold; MENDONÇA, Joseli Maria Nunes. (orgs). Direitos e Justiças no Brasil: ensaios de história social. Campinas: Editora da Unicamp, 2006.

${ }^{306}$ SOUZA, George Félix Cabral de. Op. cit. p. 53. Para Graça Salgado, as eleições dos oficiais “(...) apenas conferiam um aparente cunho liberal ao processo de escolha. Na realidade, eram limitadas a um círculo bastante restrito de indivíduos - as tais "pessoas de qualidade - e sempre supervisionadas por algum representante da Coroa: o ouvidor, o provedor ou o juiz de fora." SALGADO, Graça. Fiscais e Meirinhos: a administração no Brasil colonial. Rio de Janeiro: Nova Fronteira; Brasília: INL, 1985. p.111. 
Por meio das considerações historiográficas acerca do assunto, buscou-se avaliar a situação política da vila de Taubaté. Basicamente, visou-se identificar as pessoas que tiveram participação na Câmara local e para tanto a tarefa não foi fácil, pois a documentação relativa a este órgão, isto é, suas Atas, não existem ou pelo menos não se tem notícia delas. Visando ultrapassar o problema das fontes, a pesquisa lançou mão da seguinte estratégia: já que os inventários post-mortem eram documentos que necessitavam da aprovação oficial, isto significa que passavam pela Câmara municipal, e assim foi possível arrolar os nomes dos juízes ordinários e dos órfãos durante quase todo o período estudado. Infelizmente, não foi possível conhecer os nomes dos vereadores, mas acredita-se que tal lacuna não desqualificará a análise histórica em relação ao grupo social ligado ao mando local. Mesmo porque os dados e as conclusões aqui expostos não têm a pretensão de ter em si o fim analítico, ou seja, não constituem a "verdade absoluta" propriamente dita. São apontamentos que revelam tão somente uma aproximação à realidade.

Dos 75 anos que compreendem o período estudado, apenas para os anos de 1645, 1646, 1647, 1648 e 1654 não foi possível encontrar os nomes dos juízes. Quanto ao restante, identificaram-se 75 nomes. No entanto, destes apenas 19 possuem documentos disponíveis para análise. Então, as reflexões partirão do confronto entre os documentos relativos aos oficiais camarários e o restante da população representada pelos 197 inventários que sustentam a base desta pesquisa.

\section{Gráfico 3: Porcentagem de pessoas que ocuparam o cargo de Juiz em Taubaté, 1645 a 1720}

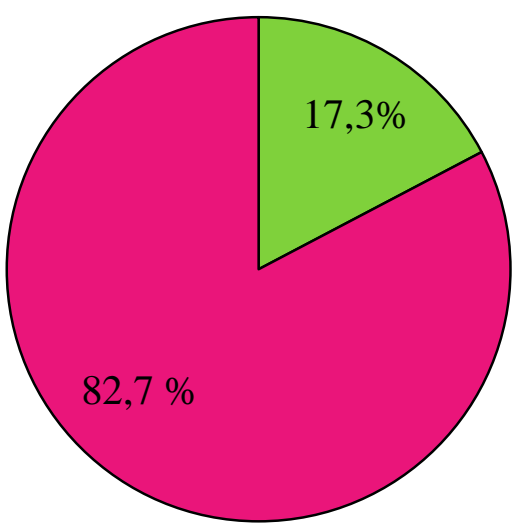

$\square$ Pessoas que ocuparam o cargo de juiz

Fonte: Inventários (1649 a 1720). Arquivo Histórico Municipal de Taubaté. 
O quadro mostra claramente o caráter minoritário do grupo ligado aos exercícios do poder local. Deve-se ter ciência de que estes números expressam apenas um indicativo, não sendo, portanto, uma expressão concreta da realidade, mesmo porque existem muitas lacunas que a documentação compulsada não permite preencher. Não obstante a falta de maiores informações que poderiam mudar os números obtidos, essa amostra denuncia o aspecto excludente do sistema político das vilas coloniais e, talvez, se se pensasse o quanto esses 17,3\% representavam frente a uma população não só de homens livres, mas também de escravos e libertos, tanto homens como mulheres, poder-se-ia imaginar tal grupo como um pequeno fragmento social.

Não é novidade a exclusão no acesso aos meios públicos de exercício do poder sofrida por grande parte da sociedade. De fato, os membros da Câmara "deveriam ser escolhidos entre os homens bons das vilas, que constituíam a elite proprietária e social da região. ${ }^{307}$ Comum a toda realidade brasileira colonial - e por que não imperial? - a história viu perpetuarem-se no controle político os chamados "principais" da terra, uma espécie de nobreza local. ${ }^{308}$ Definidos não só por critérios econômicos, mas também genealógicos principalmente em se tratando de heranças de títulos, patentes e cargos -, esses homens se destacavam perante o resto da população. Aliás, importava também, para eles, serem vistos por todos como diferentes, isto é, “(...) pertencer de fato à nobreza da terra significava ter o 'consentimento' da sociedade, ser visto por esta como nobre ou, o que é o mesmo ser reconhecido como membro de um grupo de qualidade superior." $" 309$ É preciso ressaltar o uso

\footnotetext{
${ }^{307}$ FURTADO, Júnia Ferreira. Homens de Negócio: a interiorização da metrópole e o comércio das minas setecentistas. $2^{\mathrm{a}}$. ed. São Paulo: Hucitec, 2006. p. 219.

${ }^{308}$ Evaldo Cabral de Mello assim define o significado de "principal": "Em primeiro lugar, ele denota riqueza, afluência, a posse de grandes cabedais. Em segundo lugar, o termo 'principal' era aplicado ao indivíduo que detinha uma parcela do poder político, seja por ocupar cargos públicos da capitania e de pertencer, como dizia a linguagem dos registros inquisitoriais, 'aos da governança da terra', seja devido ao fato de dispor de uma clientela ou de um séquito de homens livres e de escravos (o adjetivo 'principal' também era empregado para nomear os chefes indígenas), seja por tratar-se de religiosos ou de patentes militares, seja finalmente por ocupar uma posição proeminente." MELLO, Evaldo Cabral de. Rubro Veio: o imaginário da Restauração Pernambucana. Rio de Janeiro: Nova Fronteira, 1986. p. 159-160.

${ }^{309}$ FRAGOSO, João. "A Formação da Economia Colonial no Rio de Janeiro e de sua Primeira Elite Senhorial (séculos XVI e XVII).” In: FRAGOSO, João; BICALHO, Maria Fernanda Baptista; GOUVÊA, Maria de Fátima Silva. (org.) O Antigo Regime nos Trópicos: a dinâmica imperial portuguesa (séculos XVI e XVIII). Rio de Janeiro: Civilização Brasileira, 2001. p. 58.
} 
do termo "nobre" que, aqui, não corresponde àquele grupo de pessoas estabelecidas no entorno da figura real e que viviam de rendas dadas pelo Estado, imagem muito comum nas monarquias européias. No Brasil, no entanto, convencionou-se chamar de "nobreza da terra" as pessoas que detinham riqueza e poder, mas que estavam longe de se equiparar ao nobre reinol.

Outro fator que contribuía para a elevação do status social era a posse de patentes militares. De acordo com Christiane Pagano de Mello,

A 'nobreza' local, por não possuir herança que lhe garantisse uma posição proeminente no seio da sociedade aristocrática, buscava ascender na hierarquia social através dos cargos da administração municipal elou de patente das Ordenanças, fontes de prestígio e fatores legais de nobilitação (...). Por essas vias de ascensão social, a elite local se afirmava em nível político elou militar, articulada com o poder central que a legitimava. ${ }^{310}$

A estrutura militar portuguesa implantada no Brasil era montada, basicamente, nos mesmos moldes encontrados no reino. Desde o princípio da colonização da América, e de outras localidades, Portugal sustentou apenas uma força militar não profissional e pouco sistematizada. ${ }^{311}$ Somente após a Restauração, ocorrida em 1640, é que se vê mudanças neste quadro muito em função da forte dinâmica bélica encontrada não só na Europa como também no mundo colonial, o que deixava a Coroa lusitana e o seu imenso Império em constante perigo. Dessa maneira, procurou-se definir melhor a sua estrutura militar: em primeiro lugar foram organizadas as Tropas Regulares constituídas por homens dedicados apenas a essa função e sustentados através de soldos; em seguida havia as Tropas de Auxiliares, isto é, apesar de civis e não receberem soldo, estas "seriam treinadas e armadas de modo a ser, como segundo escalão da força militar, um contingente preparado para auxiliar a Tropa de Linha" ${ }^{312}$; e por último, e não menos importante, havia as Ordenanças que, de igual maneira que as Auxiliares, não recebiam pagamento e eram compostas pela própria população - mais precisamente a masculina entre 16 e 60 anos de idade.

\footnotetext{
${ }^{310}$ MELLO, Christiane F. Pagano de. Forças Militares no Brasil Colonial: Corpos de Auxiliares e de Ordenanças na segunda metade do Século XVIII. Rio de Janeiro: E-Papers, 2009. p. 40.

${ }^{311} \mathrm{O}$ ponta pé inicial para a organização legal de uma força militar em Portugal se deu com a legislação criada por D. João III, em 7 de agosto de 1549, e depois com a promulgação da Lei de Armas, de 9 de dezembro de 1569, e o Regimento das Ordenanças, de 10 de dezembro de 1570, ambos sob governo de D. Sebastião.

${ }^{312}$ Idem, Ibidem. p. 45-46.
} 
Com relação a Taubaté, o que tudo indica é que houve aí a presença de uma Companhia das Ordenanças e, talvez, em fins do século XVII, justamente após as descobertas oficiais de ouro, alguns habitantes da vila detiveram também patentes de militares das Tropas de Auxiliares. Embora muito semelhantes, tais corpos militares tinham suas diferenças:

Os Auxiliares eram Corpos Militares diretamente ligado ao governador da Capitania, não só pelo processo de provimento de postos de oficiais, mas também por se constituírem em forças essencialmente móveis, tropas usadas nos deslocamenteos que atendiam as necessidades estratégicas de governo. Já os Corpos de Ordenanças formavam uma força basicamente fixa e local, que não deveria ser deslocada da sede para defender outras áreas $^{313}$,

acrescenta-se ainda que era a Câmara municipal a responsável pela eleição dos oficiais deste Corpo, o que dava a esta instituição grande poder de controle. ${ }^{314}$

De maneira simplificada, visando não entrar em maiores detalhes, as patentes de oficiais de ambos os Corpos militares que atuaram em Taubaté e que, por isso mesmo, mantinha entre seus membros os moradores da vila, eram as seguintes: em termos de capitania o poder militar era comandado pelo Capitão-mor e sendo ajudado de perto pelo Sargento-mor. Já no âmbito de cada Companhia das Ordenanças havia os capitães, os alferes e os sargentos; a Tropa de Auxiliares era comandada pelo Mestre de Campo seguido pelo capitão, tenente, alferes e sargento. ${ }^{315}$ Tais postos militares eram cobiçados não apenas porque denotavam poder sobre a população mas também porque traziam consigo um efeito nobilitante ao conceder ao seu detentor certos privilégios e prestígios reconhecidos pelos rei como regalias, honras, liberdades e isenções em impostos. Vale lembrar que está se falando

\footnotetext{
${ }^{313}$ Idem, Ibidem. p. 71.

314 "As Câmaras formavam o espaço privilegiado de negociação com o poder real, na qual se viabilizava concretamente o pacto, a relação bilateral - naturalmente assimétrica pela diferença de escala - de troca entre o compromisso de obediência e fidelidade dos súditos à Coroa, e a proteção e manutenção das propriedades e privilégios da elite local, agente político da sociedade colonial. Apesar do programa de centralização político-administrativa da Coroa portuguesa, ter enfraquecido o poder dos governos municipais, as elites locais não perderam completamente o poder sobre as comunidades e continuaram a desempenhar um papel político de primeiro plano, conservando, dessa forma, um apreciável grau de autonomia." Idem, Ibidem. p. 59.

${ }^{315}$ Nas Ordenanças os postos subalternos eram o de meirinho, de escrivão e de cabo, já nas Tropas Auxiliares ainda havia o furriel, o porta-estandarte e o soldado. Sobre as funções de cada um destes postos e dos oficiais Cf. SALGADO, Graça. Fiscais e Meirinhos: a administração no Brasil colonial. Rio de Janeiro: Nova Fronteira; Brasília: INL, 1985.
} 
de uma sociedade orientada por valores estamentais, logo a posse de um cargo ou uma patente era o suficiente para a ascensão de um indivíduo.

Como a escolha de tais oficiais militares era coisa que deveria ser feita levando-se em consideração a "nobreza" e a qualidade dos candidatos, não é de se estranhar então a falta de pessoas capazes para o exercício do cargo. Assim, era muito comum a formação de grupos sociais que se auto-mantinham através de favores estamentais, isto é, tanto cargos políticos como militares eram monopolizados pelo mesmo grupo local e a perpetuação deste controle se fazia por meio da constante eleição de pessoas do próprio grupo. Portanto, usualmente "a escolha desses oficiais militares recaía sobre os que "costumam andar na governança', provocando o acúmulo de poderes municipais e militares em um mesmo homem, fator que servirá ao reforço dos governos municipais, conferindo-lhes maior poder de mando e melhor controle sobre a população.”,316

O gráfico abaixo visa mostrar o caráter excludente do acesso aos postos oficiais dos Corpos Militares.

\section{Gráfico 4: Porcentagem de Indivíduos que tiveram Patentes Militares em Taubaté, 1645 a 1720}

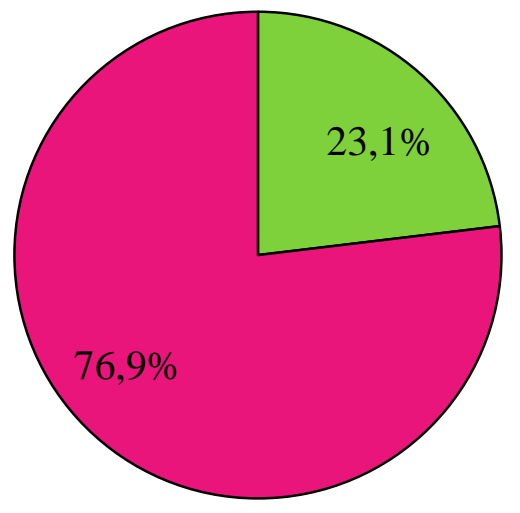

$\square$ Com Patentes

$\square$ Sem Patentes

Fonte: Idem.

A posse das patentes de oficiais militares atingiu o percentual de $23,1 \%$. Isso demonstra que, de fato, o oficialato local estava restrito a um pequeno grupo de pessoas, cerca de 1/4 da população masculina branca.

\footnotetext{
${ }^{316}$ Idem, Ibidem. p. 39-40.
} 
Como dito, não era somente a posse da patente que qualificava a pessoa, era também o poder de mando sobre outras pessoas que dela advinha. Para Carla Maria Carvalho de Almeida o prestígio obtido com a patente estava ligado ao recrutamento militar já que todos os homens maiores de dezesseis anos deveriam ser enquadrados dentro das ordenanças. Isso fazia com que os oficiais controlassem o fator de intimidação passível de afetar a vida das populações. Entende a autora que "as ordenanças funcionavam como fontes de poder local e de privilégios. Por isso mesmo, os postos de oficiais podiam, às vezes, ser motivo de disputas entre os grandes de cada localidade." ${ }^{317}$

Se isolada, "a patente embranquece e nobilita" 318 , imagine-se ela combinada com o exercício de cargos na Câmara municipal. É o que se pode ver quando se cruzam os dados das pessoas que atuaram pelo menos uma vez como juiz ordinário e/ou dos órfãos com os dados daqueles que possuíam as patentes. Do restrito grupo possuidor de patentes e que exercia cargos oficiais, apenas 37,5\% das pessoas se distinguiram por possuir os dois tipos de nobilitação, ou seja, tinham patentes e exerceram o cargo de juiz ordinário e dos órfãos. Isso em termos gerais significa dizer que aproximadamente $6 \%$ da população taubateana ocupou os setores de distinção ao deter patentes militares e cargos na Câmara municipal. Enfim, riqueza, cargos públicos e patentes militares eram o conjunto de elementos capazes de elevar o status social de uma pessoa, por isso eram cobiçados por uns e respeitados por todos.

317 ALMEIDA, Carla Maria Carvalho de. "Homens Ricos em Minas Colonial." In: BICALHO, Maria Fernanda; FERLINI, Vera Lúcia Amaral (org.). Modos de Governar: idéias e práticas políticas no Império português (séculos XVI a XIX). São Paulo: Alameda, 2005. p. 380.

${ }^{318}$ FAORO, Raimundo. Os Donos do Poder: formação do patronato político brasileiro. Vol. I, $6^{\text {a }}$. Ed. Porto Alegre: Globo, 1984. p. 192. Para este autor, a posse das patentes militares equivalia à carta de bacharel durante o período Imperial. 


\section{CAPÍTULO 3 O GRUPO SERTANISTA TAUBATEANO}

É largo o reconhecimento da participação de Taubaté no movimento sertanista que culminou no achamento de ouro no sertão dos Cataguazes, hoje Estado de Minas Gerais. De fato, não se pode negar a presença de taubateanos nos eventos cruciais que antecederam as descobertas metalíferas no Brasil. Mas isso tudo foi apenas uma consequência de um processo histórico iniciado muito tempo antes. Apesar da sua importância, pouco se sabe acerca das principais características deste processo que, em parte, se desenvolveu em Taubaté. Nesse sentido, ainda é preciso avaliar melhor o grau desta participação e a sua relevância no contexto da própria dinâmica local.

Localizar e caracterizar os indivíduos ligados às atividades sertanistas dentro do quadro espaço-temporal definido no capítulo passado é o objeto neste momento. Visando confrontar as velhas imagens consolidadas pela historiografia, procurar-se-á questionar sobre a parcela populacional envolvida no bandeirismo, sobre as suas características e interesses econômicos, sobre o seu posicionamento social, sobre as formas de organização das entradas sertanistas, além da eventual posse de patentes militares e participação na Câmara municipal.

Acredita-se que responder tais questões significará uma contribuição para a tendência de "re-moldagem" da imagem estabelecida sobre o fenômeno do bandeirismo paulista, pelo menos em se tratando da vila taubateana.

\subsection{Pessoas ligadas ao sertanismo}

O primeiro passo a ser dado consiste na identificação dos indivíduos que lidavam com as atividades sertanistas, seja esta ligação evidenciada por uma participação direta ou indireta, pois que, de uma forma ou de outra, colaboravam para a construção dessas empresas. $^{319}$

319 Para detectar tais indivíduos procedeu-se da seguinte forma: selecionou-se primeiramente os inventários que mencionavam ligações com tais empreendimentos; em seguida pesquisou-se nos próprios inventários nomes de outros indivíduos que pudessem estar ligados a elas; também se verificou nos Livros de Registros eventuais acordos estabelecidos com vistas às entradas sertanistas; por fim, através da pesquisa bibliográfica que, por vezes, indicava nomes de sertanistas. 
Tal arrolamento permitirá o manuseio de diversas informações que ajudarão a definir a tipicidade dos sertanistas e o seu formato peculiar em relação ao resto da população, se é que ele existia. A tabela e o gráfico a seguir expõem a parcela da população correspondente aos sertanistas frente à sociedade taubateana. Antes de prosseguir, porém, é preciso fazer uma ressalva: deve-se ter ciência de que os números adiante não são totalmente seguros visto que foram baseados em inventários, isto é, estes documentos registram a quantidade de sertanistas que morreram nas respectivas décadas e, por isso mesmo, as mudanças ocorridas podem também ter sido aleatórias. No entanto, ciente das limitações das fontes e salvaguardando-se dos perigos existentes, a análise destes dados é válida.

\begin{tabular}{ccccccccc}
\hline \multicolumn{2}{c}{ Tabela 18: Número real de inventários de indivíduos envolvidos nas Entradas } \\
Sertanistas, Taubaté (1650 a 1720) \\
\hline $\begin{array}{c}\text { N. total de } \\
\text { inventários } \\
\begin{array}{c}\text { Apenas } \\
\text { Sertanistas } \\
\text { Décadas }\end{array}\end{array}$ & 18 & 20 & 23 & 34 & 33 & 33 & 36 & 197 \\
\hline
\end{tabular}

Fonte: Inventários (1649 a 1720). Arquivo Histórico Municipal de Taubaté.

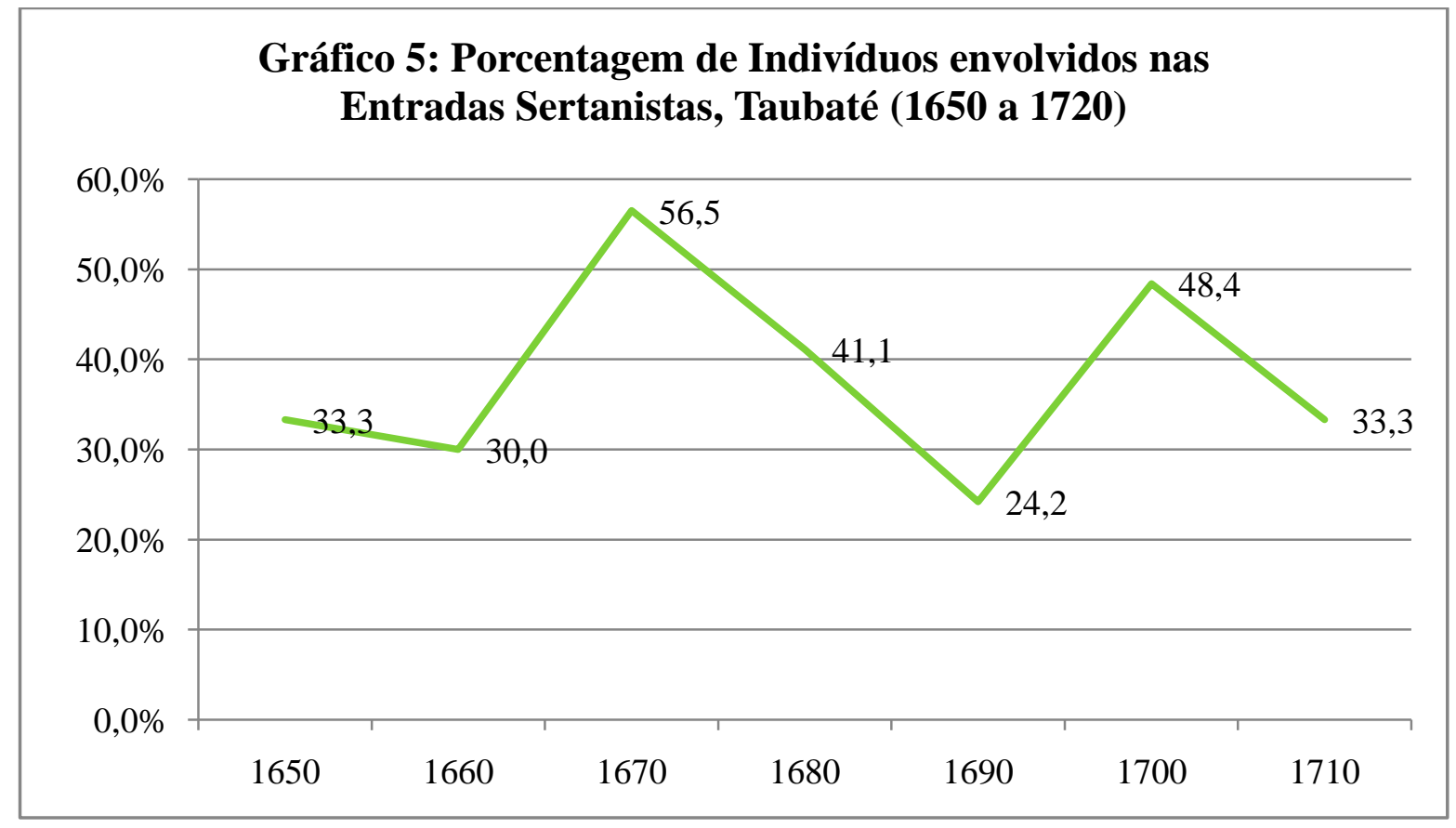

Fonte: Idem. 
Os números apresentados acima não só cogitam a formulação de concepções sobre a característica social de Taubaté, como também propõem uma legítima discussão sobre as idéias tradicionais acerca dos bandeirantes paulistas.

De imediato, o aspecto a ser notado é a não generalização da prática sertanista, isto é, não era toda a sociedade que participava dos movimentos que adentravam o sertão. Além disso, a variação no seu percentual pode ser reflexo das tendências econômicas de tais atividades dentro do contexto da vila e mais, representa também o fluxo populacional que era bastante recorrente no Brasil-colônia.

Em se tratando do bandeirismo, as décadas analisadas dividem-se da seguinte forma: 1650, 1660 e 1670 que são representativas do início e da lenta estruturação da vila em termos econômicos e sociais, sendo as incursões ao sertão uma atividade presente desde cedo e que se expandiu até tomar parte considerável da sociedade. Em separado, as décadas de 1680 e 1690 são muito interessantes. Pode-se dizer que nesse espaço de tempo a vila sofreu um processo de circulação de bandeirantes que vagavam por outras áreas em busca de riquezas (materiais e humanas) e melhores oportunidades de negócios, como no caso de Antonio Dias, fundador de Ouro Preto, que ao encontrar ouro em fins do século XVII “expediu para Taubaté a notícia do auspicioso evento, e avisou os parentes e amigos que viessem partilhar com ele da fortuna deparada." 320 Talvez o próprio sucesso da vila como lugar de organização e irradiação de sertanistas tenha sido o cerne da explicação para a locomoção de tais homens. Dessa forma, faz sentido o declínio na parcela da população envolvida com o bandeirismo.

Os sertanistas mais experientes, calejados de tanto lidarem com as dificuldades do sertão, podem ter percebido a abertura de oportunidades logo na década de 1680 e, principalmente, na de 1690, e por isso se aventuraram em busca de novos ares, daí a forte queda na porcentagem de pessoas que ainda tratavam com o sertanismo. Porém, com o florescer do século XVIII, muitos dos que saíram podem ter voltado à vila, com ou sem

\footnotetext{
320 "No ano imediato (1699) puseram-se por isso e logo a caminho Francisco da Silva Bueno e seu irmão Antônio da Silva Bueno, primos do Mestre-de-campo Domingos da Silva Bueno, e de Bartolomeu Bueno de Siqueira, Tomás e João Lopes de Camargos, sobrinhos de José de Camargos Pimentel, Félix de Gusmão de Mendonça e Bueno, e o Padre João de Faria Fialho, capelão da comitiva." VASCONCELOS, Diogo de. História Antiga das Minas Gerais. 3a . ed. vol. 1. Belo Horizonte: Itatiaia; Brasília, INL, 1974. p. 168-169.
} 
riquezas, mas possuidores de uma rica vivência no novo mercado colonial, mantendo ainda contatos com ele.

Já a população comum, diga-se dessa maneira, mesmo sem tradição nos assuntos bandeiristas, entrou no alvoroço causado com a implantação dos povoados mineiros. Tomando-se como referência a forte migração em direção às minas ocorrida neste período, fenômeno este que, além do Brasil, também atingiu a metrópole portuguesa, é inevitável pensar que parte da população de Taubaté tenha se dirigido para tal região. ${ }^{321}$ É importante deixar claro que este deslocamento de pessoas não significa, necessariamente, um decréscimo na população da vila, antes talvez uma estagnação. Enquanto uns iam, outros voltavam, assim era o cotidiano de uma vila colonial fronteiriça a um "novo mundo" sertanejo, de uma sociedade intimamente ligada às coisas do interior.

Tanto a década de 1700 como a de 1710 são parecidas. Ambas presenciaram o retorno de muitos aventureiros que antes haviam deixado a vila. A única diferença fica por conta de que, em termos gerais, num primeiro momento foram os sertanistas que retornaram, visto terem sido os pioneiros da empreitada, para depois, em seguida, ter sido a vez dos retardatários deste processo, isto é, dos indivíduos que não faziam parte do tradicional grupo bandeirista e por isso mesmo estavam um passo atrás daqueles.

${ }^{321}$ As palavras de Antonil são importantes ao denunciar a forte onda de migração gerada com as descobertas das minas de ouro. Para ele "a sede insaciável do ouro estimulou a tantos a deixarem suas terras e a meterem-se por caminhos tão ásperos como são os das minas, que dificultosamente se poderá dar conta do número das pessoas que atualmente lá estão." Sobre a confusão estabelecida na estrutura social mineira, diz ainda o jesuíta que "cada ano, vêm nas frotas quantidade de portugueses e de estrangeiros, para passarem às minas. Das cidades, vilas, recôncavos e sertões do Brasil, vão brancos, pardos e pretos, e muitos índios, de que os paulistas se servem. A mistura é de toda a condição de pessoas: homens e mulheres, moços e velhos, pobres e ricos, nobres e plebeus, seculares e clérigos, e religiosos de diversos institutos, muitos dos quais não têm no Brasil convento nem casa." ANTONIL, André João. Cultura e Opulência do Brasil. $3^{\mathrm{a}}$. Ed. São Paulo: Editora da Universidade de São Paulo, 1982. p.167. O constante deslocamento de grande massa populacional demandou a necessidade dos caminhos até as minas. Muitas pessoas viram nesta situação oportunidades de lucro, como o caso da obtenção de direitos sobre as passagens em rios. Numa provisão datada de 20 de dezembro de 1701, Artur de Sá e Menezes concede o direito de passagem pelo Rio Grande a José Pompeu Taques para, com isso, acabar com as "muitas desgraças que estão sucedendo no Rio Grande morrendo muita gente afogada", agindo assim "ao bem comum destes povos que continuam a caminho das minas". Cf. "Provisão da passagem do Rio Grande a José Pompeu Taques, dada por Arthur de Sá e Menezes, de 20 de dezembro de 1701." Documentos Interessantes para a História e Costume de São Paulo. Publicação Oficial: Arquivo do Estado de São Paulo; São Paulo: Estabelecimento Gráfico Irmãos Ferraz, 1930. Vol. LI. p.55-56. 
Como já notado em linhas anteriores, a não generalização do envolvimento direto da população nos empreendimentos sertanistas é um ponto importante e que deve ser discutido. Se ainda hoje a tendência generalizante da tipologia paulista-bandeirante se encontra presente no senso comum e faz parte dos estudos científicos, é porque foi amplamente aceita, máxime no contexto colonial, muito dependente das notícias que circulavam através das conversas entre andarilhos e que, pouco a pouco, construíam imagens que colaboravam para a criação de uma "fama" dos paulistas que, por um lado, pendia para uma "legenda negra", por outro era recebida como uma "legenda dourada". 322 Cada qual sob o seu ponto de vista, evidentemente, posto que "qualidades e defeitos aparecem, portanto, indissociados na qualificação dos paulistas durante todo o século XVII, e assim continuou depois." ${ }^{232}$

A herança colonial também pode ser visualizada no próprio entendimento que se dá ao sentido do "ser paulista", quase que exclusivamente associado o bandeirismo. Estudos feitos no século XX ratificam esta antiga ideia reproduzindo o que se sabia sobre o homem de São Paulo. As ações de alguns bandeirantes paulistas, muito conhecidas por todo o

\footnotetext{
${ }^{322}$ Raquel Glezer entende que "a 'lenda negra' que apresenta os habitantes da vila de São Paulo como cruéis assassinos, inimigos dos índios e dos padres e insubmissos vassalos dos reis de Portugal, foi elaborada nos séculos XVI e XVII, baseada nas versões dos padres jesuítas. Estes, ressentidos por suas difíceis relações com os paulistas, foram expulsos da vila na disputa pela exploração da mão-de-obra de índios aldeados, e por muito tempo impedidos de retornar. A atuação dos bandeirantes nos episódios das lutas e disputas de fronteira entre as duas Coroas ibéricas, nos setecentos, apenas agravou o conflito dos paulistas com os jesuítas. (...) A 'lenda dourada' por seu lado, considera os habitantes da Capitania criadores da nacionalidade, concretizadores da obra de colonização, integradores da população indígena no povo brasileiro, defensores do Estado português, proféticos premonitores de um futuro grandioso e brilhante." GLEZER, Raquel. Chão de Terra e Outros Ensaios sobre São Paulo. São Paulo: Alameda, 2007. p. 44-45. Já para Adriana Romeiro, "a legenda negra não era obra exclusiva dos jesuítas espanhóis, em protesto contra a destruição das grandes reduções jesuíticas do Guairá. Se eles desempenharam um papel decisivo na construção da legenda negra, é bem verdade que esta também se alimentou de outras fontes, que confluíram para formar a imagem negativa da gente do Planalto. Em 1628, o fidalgo militar D. Luís de Céspedes Xería visitou a Vila de São Paulo e escreveu horrores sobre os seus moradores (...).” E mais, "tão disseminado estava esse imaginário em terras americanas que todo estrangeiro que aqui aportasse logo tomaria conhecimento da singular e pitoresca aventura dos paulistas." ROMEIRO, Adriana. Paulistas e Emboabas no Coração das Minas: idéias, práticas e imaginário político no século XVIII. Belo Horizonte: Editora UFMG, 2008. p. 225 e segs. Para um aprofundamento na discussão sobre a dicotomia das imagens acerca dos paulistas Cf. SOUZA, Laura de Mello e. $O$ Sol e a Sombra: política e administração na América portuguesa do século XVIII. São Paulo: Companhia das Letras, 2006. Mais precisamente o capítulo intitulado "São Paulo dos Vícios e das Virtudes".
}

${ }^{323}$ SOUZA, Laura de Mello e. Op. cit. p. 116. 
Brasil, faziam ampliar cada vez mais o seu espectro aventureiro e desbravador. Seja por meio de serviços prestados para o governo na luta contra indígenas, seja no combate aos quilombos, seja na caça e escravização de nativos, ou ainda no trabalho de prospecção, a capitania inteira se destacava como seleiro de homens diferenciados.

Através de suas atividades sertanistas, do contato muito próximo com a cultura indígena, adotando-a vantajosamente devido ao próprio contexto, "com o correr do tempo, os paulistas tornaram-se tão habilitados nas artes do sertão e dos matagais quanto os ameríndios já o eram, ou mesmo, segundo alguns contemporâneos, 'como as próprias feras'. ${ }^{324}$ Esta era uma das opiniões correntes a respeito dos paulistas.

Aliás, os jesuítas também tiveram grande influência na disseminação deste estado de quase selvageria. Contrária às caçadas de escravização indígena, a Companhia de Jesus esteve sempre do lado oposto aos bandeirantes, combatendo e sendo combatida numa briga que levou centenas de anos de comprometimento entre ambas as partes. Nesse sentido, como não podia deixar de ser, os jesuítas divulgavam notícias variadas que, intencionalmente, buscavam denegrir o bandeirante e suas ações, sempre as associando ao homem de São Paulo, sem distinção em relação aos outros habitantes da capitania. Também entre os espanhóis, esta fama se espalhava. Assim, "aos mamelucos de São Paulo se referem com rancor os depoimentos espanhóis da época em que, devastando as missões do vale do Paraná, ameaçavam talvez Assunção, Buenos Aires, Potosi, as riquezas do Peru.” Desta maneira,

cresceu-lhes a fama de incomparáveis desbravadores, conhecendo como ninguém os segredos da selva, instruídos pelos índios nas artes de paz e luta, dotados das suas faculdades sutis de astúcia, sobriedade e resistência, tão adaptados à natureza que pouco pediam a civilização, mas na realidade impiedosos para com eles, como se os separasse uma incompatibilidade vingativa. ${ }^{325}$

Portanto, vê-se claramente que, "por todo o século XVII, paulista e sertanista, além de rima, eram sinônimos." 326 Forte e estreita ligação que passou a ser, hoje em dia, um paradigma disseminado no âmbito do conhecimento científico e popular.

${ }^{324}$ BOXER, Charles R. A Idade de Ouro do Brasil: dores de crescimento de uma sociedade colonial." $3^{\text {a }}$. ed. Rio de Janeiro: Nova Fronteira, 2000. p. 58.

${ }^{325}$ CALMON, Pedro. História do Brasil. Vol. II. 2a . ed. Rio de Janeiro: José Olympio, 1963. p. 450. ${ }^{326}$ SOUZA, Laura de Mello e; BICALHO, Maria Fernanda Baptista. 1680-1720: império deste mundo. São Paulo: Companhia das Letras, 2000. p. 29. 
Adotando esta imagem sem questioná-la, talvez até deliberadamente, Belmonte ao se referir às empresas paulistas de aprisionamento indígena diz que entre toda a sociedade "não há quem não o faça" dando a elas um caráter comum e mesmo necessário tendo em vista o ato de ir ao sertão para "buscar o seu remédio." ${ }^{327}$ Em outra passagem em que trata dos períodos em que ocorriam as entradas sertanistas que partiam de São Paulo, ratifica esta opinião ao mencionar que "toda a vila, excetuados os inválidos e as mulheres, sai por esses matos brutos. ${ }^{328}$ Ou seja, a prática sertanista, para ele, era uma atividade comum a todos, não havendo nem mesmo uma mínima parcela da sociedade que nela não atuasse.

Também analisando a civilização do planalto paulista sob a ótica da formação de uma raça distinta no interior do processo de colonização do Brasil, Alfredo Ellis Júnior associa o paulista ao bandeirante quase que de uma maneira natural, como se, inevitavelmente, os paulistas, "essa gente bandeirante", fosse talhada e determinada ao sertanismo. Em outras palavras, o bandeirismo seria uma exteriorização inevitável da característica biológica dos paulistas, aliás, de todos os habitantes da capitania, sem exceção. $^{329}$

A tradicional imagem do paulista bandeirante, construída inicialmente no século XVII, serviu de base para a afirmação ideológica dos estudiosos do século XX que defendiam o ponto de vista político hegemônico do Estado de São Paulo frente ao resto do país. Logo, a ligação estreita dos habitantes de uma região a uma dada atividade, no caso a sertanista, tornou-se a base da figura do "ser paulista". Não bastava ser sertanista, tinha de ser parte do "grupo seleto" dos homens do planalto piratiningano.

Tanto as considerações dos colonos acerca de São Paulo, quanto as intencionalidades adotadas pela historiografia do século XX devem ser vistas e analisadas como frutos das próprias condições contextuais. Isto posto, e observando o gráfico anterior, é lícito pensar numa eventual e depois intencional generalização de um estereótipo paulista, o que na verdade não traduzia por completo a realidade, pois não eram todas as pessoas que estavam ligadas às atividades sertanistas, pelo menos em se tratando da vila de Taubaté.

${ }^{327}$ BELMONTE. No Tempo dos Bandeirantes. Coleção Paulística. Vol. 20. São Paulo: Governo do Estado, 1980. p. 41.

${ }^{328}$ Idem. Ibidem. p. 268.

329 ELLIS JÚNIOR, Alfredo. Raça de Gigantes: a civilização no planalto paulista. São Paulo: Editora Helios Limitada, 1926. p. 61. 
De forma geral, a formação de um paradigma histórico serviu aos objetivos de muitos estudiosos engajados num processo de legitimação da superioridade paulista. Porém, muitos outros pesquisadores, e mesmo o senso comum, adotaram esta maneira de se observar o passado. Os trabalhos que contemplam São Paulo como objeto de estudo quase sempre percorrem os mesmos caminhos conceituais, às vezes já bastante desgastados, que acabam por reafirmar alguns vícios historiográficos. Raquel Glezer, por exemplo, chama a atenção para o sentido da "inclusão" percebido facilmente quando se trata de São Paulo em termos territoriais. Segundo Glezer, nessa perspectiva, "todos os habitantes do vago espaço são bandeirantes, são paulistas, herdeiros de uma longa tradição de arrojo, coragem, ousadia." Para isso, "basta estar no espaço, exercer alguma atividade econômica de porte para ser bandeirante. Espírito bandeirante possuem todos os moradores do espaço!"330

Enfim, a extensão da prática sertanista dada automaticamente à população geral da capitania de São Vicente deve ser repensada. No caso da vila de Taubaté pôde ser visto que esta natural associação não se fundamenta, e é possível que em outras localidades tal situação se assemelhe a este quadro de não-generalização da atividade bandeirante.

Cabe, agora, verificar a configuração econômica do grupo populacional envolvido no bandeirismo, suas características e seus interesses.

\subsection{Universo Econômico dos Sertanistas}

Como foi visto até aqui, Taubaté era uma vila que estava assentada numa produção agrária e escravista. Os frutos dessa atividade eram comercializados entre os seus próprios habitantes, além de outras localidades próximas. Longe de ser apenas uma economia de subsistência, a sua dinâmica comercial extrapolava os meros tratos residenciais. Essas e outras imagens pré-estabelecidas sobre a vila taubateana - e as demais da região - já foram discutidas e revisadas sob novo ponto de vista. Avançando nesse sentido, a análise que antes se preocupou com a vila de maneira geral, agora incide apenas nos indivíduos envolvidos nas atividades sertanistas.

Os dados obtidos já provaram que não era toda a sociedade que tratava dos assuntos sertanistas. Aliás, mostrou também a necessidade de se repensar a associação feita quase que espontaneamente entre o paulista e o bandeirante.

\footnotetext{
${ }^{330}$ GLEZER, Raquel. Op. cit. p. 150.
} 
Em termos de economia a presente análise tende a situar os sertanistas dentro do quadro geral encontrado na vila, buscando com isso verificar as possíveis diferenças em suas características e seus interesses.

As tabelas seguintes trazem números (reais e percentuais) correspondentes à riqueza dos sertanistas e à forma como ela estava distribuída entre os itens considerados na pesquisa. $^{331}$

Tabela 19: Composição da riqueza dos sertanistas de Taubaté por setor econômico (em valores reais)

\begin{tabular}{lccccccc}
\hline Item & $\mathbf{1 6 5 0}$ & $\mathbf{1 6 6 0}$ & $\mathbf{1 6 7 0}$ & $\mathbf{1 6 8 0}$ & $\mathbf{1 6 9 0}$ & $\mathbf{1 7 0 0}$ & $\mathbf{1 7 1 0}$ \\
\hline Rural & $201 \$ 880$ & $121 \$ 430$ & $265 \$ 420$ & $670 \$ 330$ & $281 \$ 920$ & $2: 704 \$ 170$ & $5: 674 \$ 260$ \\
Urbano & $9 \$ 600$ & $12 \$ 000$ & $73 \$ 400$ & $126 \$ 380$ & $98 \$ 240$ & $427 \$ 000$ & $934 \$ 520$ \\
Escravo & $2: 439 \$ 000$ & $1: 898 \$ 000$ & $3: 729 \$ 000$ & $10: 118 \$ 700$ & $1: 971 \$ 400$ & $18: 665 \$ 000$ & $25: 984 \$ 000$ \\
Ouro & 0 & $34 \$ 000$ & $8 \$ 140$ & $38 \$ 500$ & $16 \$ 250$ & $4: 148 \$ 365$ & $10: 472 \$ 145$ \\
Prata & $12 \$ 820$ & $38 \$ 720$ & $13 \$ 900$ & $48 \$ 660$ & $38 \$ 340$ & $392 \$ 940$ & $275 \$ 411$ \\
Comércio & $48 \$ 940$ & 0 & 0 & $113 \$ 160$ & $58 \$ 380$ & $648 \$ 515$ & $43 \$ 360$ \\
P. Vida & $133 \$ 920$ & $78 \$ 880$ & $118 \$ 500$ & $226 \$ 660$ & $241 \$ 040$ & $1: 503 \$ 450$ & $2: 490 \$ 010$ \\
Div. Ativa & $98 \$ 300$ & $382 \$ 160$ & $112 \$ 160$ & $395 \$ 160$ & $321 \$ 430$ & $2: 473 \$ 396$ & $9: 476 \$ 127$ \\
Sertanismo & $34 \$ 540$ & $64 \$ 200$ & $57 \$ 160$ & $95 \$ 360$ & $80 \$ 740$ & $372 \$ 160$ & $180 \$ 440$ \\
Monte-mor & $2: 979 \$ 000$ & $2: 629 \$ 390$ & $4: 357 \$ 880$ & $11: 833 \$ 710$ & $3: 107 \$ 740$ & $30: 272 \$ 896$ & $55: 530 \$ 273$ \\
Div. Passiva & $546 \$ 749$ & $246 \$ 940$ & $850 \$ 371$ & $1: 237 \$ 610$ & $551 \$ 050$ & $8: 088 \$ 842$ & $14: 903 \$ 654$ \\
Monte-menor & $2: 432 \$ 251$ & $2: 382 \$ 450$ & $3: 507 \$ 509$ & $10: 596 \$ 100$ & $2: 556 \$ 690$ & $22: 184 \$ 054$ & $40: 626 \$ 619$ \\
Inventários & 6 & 6 & 13 & 14 & 8 & 16 & 12 \\
\hline
\end{tabular}

Fonte: Inventários (1649 a 1720). Arquivo Histórico Municipal de Taubaté.

Tabela 20: Composição da riqueza dos sertanistas de Taubaté por setor econômico (em porcentagem)

\begin{tabular}{lccccccc}
\hline Item & $\mathbf{1 6 5 0}$ & $\mathbf{1 6 6 0}$ & $\mathbf{1 6 7 0}$ & $\mathbf{1 6 8 0}$ & $\mathbf{1 6 9 0}$ & $\mathbf{1 7 0 0}$ & $\mathbf{1 7 1 0}$ \\
\hline Rural & 6,77 & 4,61 & 6,09 & 5,56 & 9,07 & 8,93 & 10,21 \\
Urbano & 3,22 & 0,45 & 1,68 & 1,06 & 3,16 & 1,41 & 1,68 \\
Escravo & 81,87 & 72,18 & 85,56 & 85,50 & 63,43 & 61,65 & 46,79 \\
Ouro & 0 & 1,29 & 0,18 & 0,32 & 0,52 & 13,70 & 18,85 \\
Prata & 0,43 & 1,47 & 0,31 & 0,41 & 1,23 & 1,29 & 0,49 \\
Comércio & 1,64 & 0 & 0 & 0,95 & 1,87 & 2,14 & 0,07 \\
P. Vida & 4,49 & 2,99 & 2,71 & 1,91 & 7,75 & 4,96 & 4,48 \\
Div. Ativa & 3,29 & 14,53 & 2,57 & 3,33 & 10,34 & 8,17 & 17,06 \\
Sertanismo & 1,15 & 2,44 & 1,31 & 0,80 & 2,59 & 1,22 & 0,32 \\
Monte-mor & $100 \%$ & $100 \%$ & $100 \%$ & $100 \%$ & $100 \%$ & $100 \%$ & $100 \%$ \\
& $2: 979 \$ 000$ & $2: 629 \$ 390$ & $4: 357 \$ 880$ & $11: 833 \$ 710$ & $3: 107 \$ 740$ & $30: 272 \$ 896$ & $55: 530 \$ 273$ \\
Div. Passiva & 18,35 & 9,39 & 19,51 & 10,45 & 17,73 & 26,71 & 26,83 \\
Monte-menor & $81,65 \%$ & $90,61 \%$ & $80,49 \%$ & $89,55 \%$ & $82,27 \%$ & $73,29 \%$ & $73,17 \%$ \\
& $2: 432 \$ 251$ & $2: 382 \$ 450$ & $3: 507 \$ 509$ & $10: 596 \$ 100$ & $2: 556 \$ 690$ & $22: 184 \$ 054$ & $40: 626 \$ 619$ \\
Inventários & 6 & 6 & 13 & 14 & 8 & 16 & 12 \\
\hline
\end{tabular}

Fonte: Idem.

${ }^{331}$ Ver a relação descritiva dos itens na página 87 e 88. 
Ambas as tabelas expõem dados que auxiliam em muito o exercício da observação do grupo sertanista, permitindo não só o mapeamento do seu universo econômico, denotando seus principais interesses, mas também compará-lo com o resto da população, exercício este importante para a caracterização sócio-econômica dos indivíduos envolvidos nas expedições tanto de caça de índios como na de prospecção.

A primeira das duas tabelas, a que traz nas informações os valores reais, será melhor utilizada quando for colocada lado a lado com os dados referentes à vila em geral, ou seja, a comparação entre tais valores possibilitará a identificação dos níveis de posse de riqueza referente a cada segmento social, principalmente no que tange à distribuição nos diferentes itens e a variação no padrão de investimento. Para tanto, outras tabelas serão elaboradas e expostas mais adiante. Agora algumas considerações podem ser feitas a respeito do que se vê na tabela.

Ao longo do período estudado, a vila como um todo apresentou um processo de enriquecimento, sendo que os sertanistas acompanharam naturalmente este processo. Tal desenvolvimento está bem visível através dos números. No entanto, a década de 1690 parece ser um vale que interrompeu a tendência de crescimento econômico desses homens, pois a queda no montante da soma de suas riquezas foi excessiva. Este fato pode ser explicado pelo próprio sucesso do movimento sertanista levado a cabo pelos desbravadores da vila, isto é, com as primeiras descobertas auríferas e o crescente interesse na mineração, além da abertura de novas oportunidades, houve um surto aventureiro que acabou por deslocar muitos sertanistas para fora da vila de Taubaté, fenômeno que pode ser observado por meio do gráfico $5 .^{332}$ Os anos seguintes, a partir do início do século XVIII, confirmam esta realidade ao presenciarem uma situação contrária. $\mathrm{O}$ aumento na existência de sertanistas na vila sugere que muitos dos que saíram da vila em tempos passados podem ter voltado, contribuindo com o aumento na riqueza do grupo, cada indivíduo com a sua parcela, uns mais e outros menos.

A outra tabela, a que mostra a composição da riqueza em termos percentuais, é bastante útil para se entender os interesses particulares dos sertanistas ao longo das sete décadas estudadas. É factível a observação das mudanças ocorridas nos setores de maiores ou menores interesses econômicos, podendo variar de um período para outro o grau de

\footnotetext{
${ }^{332}$ Conferir na página 127.
} 
riqueza depositado em cada item. Assim, os números acima disponibilizam traços que evidenciam os aspectos da realidade colonial da vila de Taubaté sob o ponto de vista do grupo de homens que lidavam com as expedições sertanistas através de muitas maneiras.

Durante quase todo o período considerado, os dois itens de maior impulso econômico dos sertanistas eram o escravo e o rural. Esta combinação nada mais é do que a base da produção colonial, a mais típica imagem dada a uma vila, situação já comprovada no capítulo anterior. Os setores mais seguros eram exatamente os mais procurados, e mesmo os sertanistas, que viviam sertão adentro, também compartilhavam desta opinião. Conforme se observa a economia dos sertanistas estava em sua grande maioria assentada na produção agrária, prática muito comum a toda a população.

A situação das décadas iniciais, até pelo menos 1680, parece ser de poucas mudanças. Estas só começaram ocorrer nos anos após as primeiras descobertas oficias nas minas dos Cataguazes, no despertar da década de 1690. Somente deste período em diante é que os números se deslocam, dando nova configuração ao quadro econômico da vila. Não se pode esquecer que em termos reais tem-se uma queda no conjunto da riqueza, mas, depois, há uma grande retomada no crescimento. Apesar da diminuição do comprometimento da riqueza depositada nos escravos, isto não quer dizer que houve um desinteresse por este item, ao contrário, ainda continuou sendo a prioridade, seguida pela posse de terras. Tal queda sucedeu porque começaram a surgir outros setores de crescente importância, no caso, o ouro e as dívidas. Portanto, depois de iniciada a exploração mineira, ocorreu uma diversificação no padrão de interesses econômicos da vila, isto é, uma ampliação no leque de possibilidades de distribuição de sua riqueza, contribuindo assim para a maior dinamização produtiva e comercial dela. Tal diversificação não colocou em risco a base agrário-escravista de Taubaté, ao invés disso, a consolidou, uma vez que disponibilizou recursos econômicos necessários à inserção de indivíduos no mercado produtivo e comercial.

Alguns pontos notados com a análise destas tabelas devem ser melhor tratados, pois acarretam problemas com a historiografia sobre o assunto. São dois os problemas, mais especificamente: a não especialização do sertanista e o nível de gastos nas expedições.

Os dados obtidos possibilitaram uma verticalização na análise sobre o bandeirismo. Depois de já se ter visto que não era toda a população que praticava tais empreendimentos, 
agora se percebe que nem mesmo os próprios sertanistas viviam somente das expedições, ou seja, além destas existiam outras atividades econômicas exercidas por eles.

$\mathrm{Na}$ tabela 19, as informações acerca da distribuição da riqueza dos sertanistas permitem dizer que os setores de maior peso econômico eram os mesmos procurados pela população em geral; tanto sertanistas como não sertanistas compartilhavam das mesmas tendências econômicas, presentes, aliás, na base da economia local, senão colonial. Assim, a posse de escravos e de terras configurava a lógica do sistema. Mesmo com algumas variações nos níveis de comprometimento, principalmente no início do século XVIII, com a abertura de novas oportunidades de negócios, tal base econômica se manteve, talvez até se reforçando ainda mais com a crescente injeção de riquezas através de mão-de-obra africana adquirida com recursos oriundos das explorações mineiras.

Enfim, é preciso pensar no sertanista não como um homem que vivia única e exclusivamente das expedições e em função delas. Logicamente que estas e os seus frutos eram importantíssimos para a manutenção da dinâmica econômica tanto dos sertanistas como da vila em geral, mas existiam também outras atividades que demandavam igual atenção.

Envolvido com as expedições de apresamento, Manoel Monteiro Bezerra também se ocupava com os negócios da fazenda. Consta em seu inventário, datado de 20 de outubro de 1660, que possuía canaviais em seu sítio, um alambique "de destilar aguardente", uma moenda de moer cana e uma prensa. ${ }^{333}$ Em 1683, Isabel da Cunha, viúva do sertanista Pedro Gil, além de continuar com a tradição familiar nos tratos do sertão, manteve a propriedade rural ativa produzindo algodão, ao que tudo indica, para fins comerciais. Há entre os seus bens um "tear de tecer pano de algodão", quatro arrobas de algodão e onze libras e meia de fio de algodão fino. Note-se que a atividade da família não apenas se direcionava para o cultivo do algodão mas também para a sua manufatura, coisa que dava aos seus produtos maior saída no mercado, seja através da comercialização seja como moeda de troca. Isso de fato ocorria visto que está registrado em seu inventário que o Capitão Manoel Vieira Sarmento era a dever o valor referente a duzentas varas de pano de algodão. ${ }^{334}$ Os inventários consultados indicam que tanto o algodão como a cana-de-açúcar

\footnotetext{
${ }^{333}$ Inventário de Manoel Monteiro Bezerra (1660). Cx: 1649-1667. A.H.M.T.

${ }^{334}$ Inventário de Isabel da Cunha (1683). Cx: 1678-1689. A.H.M.T.
} 
eram os tipos de cultivo mais comuns na vila. Não foram poucos os documentos que registraram estas informações.

Outro sertanista que também diversificava seus negócios foi Diogo Teixeira da Cunha. Seu inventário, que data de 16 de junho de 1699, mostra que possuía um sítio com quatro canaviais, uma moenda, um tear com dois pentes finos, uma arroba e quatro libras de algodão, um "caroçador", uma urdideira e "vinte e uma libras de fumo que levou para as minas."335 Aliás, a criação de um novo mercado consumidor nas Minas Gerais foi fator determinante para a economia de Taubaté visto que para lá se dirigia grande parte desta produção. Sem maiores detalhes, infelizmente, o Capitão Antonio de Barros Freire declarou, em 11 de setembro de 1701, no inventário de sua mulher, Catarina Sisneira de Albernaz, que "nas minas tinha cento e dez mil réis que mandou com algumas coisas para lucrar e se obrigava a todo o tempo dar contas para efeito de se repartir com os órfãos."336 A forte demanda existente nas minas foi benéfica para a economia taubateana pois favoreceu o seu desenvolvimento. João Delgado de Escobar, oriundo de família tradicionalmente sertanista, além de possuir "terras com moenda e prensa" e duzentos e vinte e oito varas de fumo, tinha encomendado um alambique que se estava esperando chegar do Rio de Janeiro. ${ }^{337}$

Houve casos em que o desenvolvimento de atividades econômicas fugia do padrão agrário. Os herdeiros de Francisco Coelho de Abreu disseram, por exemplo, que ele possuía uma olaria. ${ }^{338}$ No inventário de Antonio Vieira da Maia, feito no ano de 1674, consta que possuía uma moenda velha, dois teares com vários pentes, uma urdideira e uma tenda de ferreiro com "seus aviamentos: um torno grande, uns tais antigos com uns foles velhos, um malho, um martelo, três tenazes, três craveiras, um tufo grande e um pequeno, um ferro de culatra e uma tarracha." ${ }^{339}$ Já no arrolamento dos bens pertencentes a Francisco Pedroso há uma tenda de sapateiro "com vinte formas, uma tezoura, um troquel, um cravador, sete sovelas, um compasso, um ferro de pique, um vazador e dois piques de abrir.” A produção de sapatos, ou o conserto deles, fez parte das preocupações de Francisco até sua morte,

\footnotetext{
${ }^{335}$ Inventário de Diogo Teixeira da Cunha (1699). Cx: 1691-1699. A.H.M.T.

${ }^{336}$ Inventário de Catarina Sisneira de Albernaz (1701). Cx: 1700-1703. A.H.M.T.

${ }^{337}$ Inventário de João Delgado de Escobar (1713). Cx: 1704-1717. A.H.M.T.

${ }^{338}$ Inventário de Francisco Coelho de Abreu (1697). Cx: 1691-1699. A.H.M.T.

${ }^{339}$ Inventário de Antonio Vieira da Maia (1674). Cx: 1668-1677. A.H.M.T.
} 
visto que faleceu sem poder entregar ao juiz ordinário de Taubaté, Salvador Machado, "dois pares de sapatos de cordavão" que lhe devia. ${ }^{340}$

Enfim, é evidente que os sertanistas não viviam exclusivamente das expedições mato adentro, mesmo porque estas ocorriam esporadicamente, e essa constatação causa um embate entre algumas idéias consolidadas pela historiografia. É muito comum encontrar autores que defendem o bandeirismo como uma atividade especializada, inclusive nos moldes de um tipo de "profissão". Este ponto de vista é encontrado nas palavras de Edmundo Zenha, nas de Washington Luís e Myriam Ellis, por exemplo. ${ }^{341}$ Nesse sentido, já que era uma profissão, outros estudiosos acreditam na existência de escolas de aprendizagem à maneira da Escola de Sagres onde jovens treinavam para o exercício do ofício. $^{342}$

Talvez a realidade não chegasse a tanto. É possível que haja um exagero nessas afirmações. Embora as entradas sertanistas tenham sido práticas econômicas, muitas vezes até negociáveis em termos de contratos de prestação de serviços, como visto nas ações de alguns paulistas no combate a índios e quilombolas no nordeste do Brasil, não é correto adjetivá-las de "profissão", pois é um termo carregado de significados que podem levar a uma análise anacrônica do fenômeno. Seria melhor pensá-las como uma atividade auxiliar, ou mesmo complementar, que viabilizava o desenvolvimento da colonização. Em outras palavras, a caça de índios como forma de aquisição de mão-de-obra - prioritariamente - e a procura de metais e pedras preciosas serviam como resposta imediata às necessidades de

\footnotetext{
${ }^{340}$ Inventário de Francisco Pedroso (1687). Cx: 1678-1689. A.H.M.T.

${ }^{341}$ ZENHA, Edmundo. Mamelucos. São Paulo: Empresa Gráfica da Revista dos Tribunais, 1970. p. 12. LUÍS, Washington. Na Capitania de São Vicente. Belo Horizonte, São Paulo: Itatiaia-Edusp, 1980. p. 191. ELLIS, Myriam. “As Bandeiras na Expansão Geográfica do Brasil”. In: HOLANDA, Sérgio Buarque de. História da Civilização Brasileira. Tomo I, Volume I, Rio de Janeiro: Bertrand, 1989.

${ }^{342}$ É o caso de Waldomiro Benedito de Abreu que afirma ter existido em Santo André e São Paulo uma escola sertanista à maneira da Escola de Sagres. Cf. ABREU, Waldomiro Benedito de. Pindamonhangaba: tempo e face. Aparecida: Editora Santuário, 1977. p. 96. Na verdade, a própria existência da Escola de Sagres foi tema de debate na historiografia portuguesa. Desde o princípio do século XX que a ideia de uma escola náutica fundada pelo Infante D. Henrique, onde se agrupariam os mais variados sábios, de várias partes da Europa, com o objetivo de obter uma vasta informação sobre determinadas áreas científicas como a geografia, a astronomia ou a cartografia, se encontra ultrapassada. Esta ideia é sobretudo uma lenda que carece de provas evidentes, devida principalmente a escritores e historiadores ingleses que procuraram promover a figura e a ação do Infante de Sagres. Cf. ALBUQUERQUE, Luís de. "Escola de Sagres" In: SERRÃO, Joel (Dir.) Dicionário de História de Portugal. Vol. III, Lisboa: Iniciativas Editoriais, 1971. p. 716-717.
} 
que carecia o processo de ocupação e exploração local. A própria diversificação das atividades econômicas, produtivas e comerciais dos sertanistas, aliada às expedições, ratifica a imagem da não profissionalização do indivíduo que adentrava os sertões somente em momentos na busca de riquezas humanas e materiais. Também para Alfredo Ellis Júnior “(...) nunca a indústria dos apresamentos formou uma classe à parte, como seria de se pensar, e sim foi constituída pelos próprios agricultores, que iam ao sertão buscar gente para as suas fazendolas.",343

Portanto, é lícito afirmar que os bandeirantes eram pessoas comuns, iguais a todas as outras ao seu redor, principalmente em se tratando de práticas de vivência, isto é, estavam inseridos em um mesmo conjunto de valores econômico-sociais e dele compartilhavam. Diferenciavam-se apenas por desenvolver uma atividade econômica assentada na caça de índios e procura de metais preciosos, isto é, empregavam tempo e dinheiro no sertanismo, coisa nada comum a toda população.

$\mathrm{O}$ outro ponto interessante que deve ser mencionado refere-se ao custo despendido na organização e execução das expedições. Como visto, é sabido que nem todos participavam de tais empreendimentos. Falta verificar, agora, a possível existência de barreiras econômicas e sociais que impediam a atuação de mais pessoas neste setor.

Recorrendo à historiografia sobre São Paulo colonial, são muitas as opiniões quanto ao custo de uma expedição. Divergem os autores sobre o assunto, uns preferem defender o baixo custo, outros já são partidários da opinião de que eram muito onerosas.

A velha relação entre a pobreza e o sertanismo por muito tempo foi aceita como causa e conseqüência. Para Pedro Calmon "a pobreza estimulava, em São Paulo, esse amor do sertão" e era percorrendo as terras desconhecidas durante meses e anos que o sertanista supria suas necessidades, buscando no sertão o seu "remédio". 344 Entende-se que, sob tal ponto de vista, todos os que participavam das entradas eram pobres e a própria organização destas não demandava muitos recursos, já que seus membros não os possuíam em larga escala. A atividade sertanista seria, assim, uma alternativa para a péssima situação de pobreza em que viviam a população da capitania de São Vicente, ou seja, uma prática exclusiva dos despossuídos. Também pensando numa tendência "democrática" de tais

${ }^{343}$ ELLIS JÚNIOR, Alfredo. Raça de Gigantes: a civilização no planalto paulista. São Paulo: Editora Helios Limitada, 1926. p. 213.

${ }^{344}$ CALMON, P. História do Brasil. Vol. II. 2a . Ed. Rio de Janeiro: José Olympio, 1963. p. 576. 
empreendimentos, Myriam Ellis exprime que as bandeiras eram acessíveis a todos os homens. $^{345}$

Em sentido inverso, outros autores preferem não aceitar tal argumentação. Defendem que as entradas sertanistas eram bastante onerosas e por isso tendiam a ser manipuladas por uma parcela da sociedade que dispunha de recursos suficientes para a prática dessas atividades. Para Maurício Martins Alves "a montagem de uma bandeira requer um alto investimento inicial, o que impede a maior parte da população de realizála." ${ }^{346}$ Dessa maneira, o fator econômico surge como critério de participação ou não de pessoas nas expedições, ou seja, eram somente os sertanistas como grupo social que detinham meios materiais que os qualificavam para essa condição.

Portanto, de um lado têm-se aqueles que pensam nas entradas sertanistas como resultados imediatos a uma situação de extrema pobreza e, de outro, aqueles que excluem os despossuídos de recursos financeiros por não estarem aptos para tais empreendimentos. Talvez essa dicotomia deva ser reavaliada. Mais do que apenas quesitos econômicos, outros fatores também podiam influenciar na participação popular no bandeirismo. Além do que, há indícios que levam a crer na possibilidade de que tenham existido diferentes níveis tanto de organização como de participação nas entradas, o que será analisado em seguida.

\subsubsection{Formas de organização e participação nas entradas sertanistas}

Algumas considerações devem ser feitas sobre o que as tabelas 18 e 19 mostram com relação aos gastos despendidos em materiais típicos de uma realidade assentada em constantes confrontos. A violência fazia parte da vida dos colonos em geral, porém mais acentuada era ela, naturalmente, para aqueles que passavam boa parte do tempo dispersados em matos desconhecidos em busca de mão-de-obra escrava e riquezas minerais.

Os instrumentos bélicos não eram extravagâncias de um ou de outro que desejava ostentar poder e vaidade, era sim uma necessidade intrínseca ao próprio processo de colonização do Brasil. Seja para defesa, seja para ataque, ou mesmo para a exploração através de expedições, as armas estavam sempre no rol dos bens dos que participavam

${ }^{345}$ Cf. ELLIS, Myriam. “As Bandeiras na Expansão Geográfica do Brasil.” In: História Geral da Civilização Brasileira. Tomo I, Vol. I, Rio de Janeiro: Bertrand, 1989.

346 ALVES, Maurício Martins. Caminhos da Pobreza: a manutenção da diferença em Taubaté (1680-1729). Taubaté: Prefeitura Municipal de Taubaté, 1998. p. 59. 
efetivamente deste processo. Se as armas de fogo e as armas brancas eram itens de extrema utilidade no cotidiano de uma vila, eram ainda muito mais numa expedição sertanista, avolumando com isso os gastos efetuados na sua organização e efetivação.

O item "Sertanismo" relacionado nas tabelas acima visa, então, dar uma idéia do peso econômico que os materiais bélicos geravam na riqueza dos habitantes da vila de Taubaté evolvidos com as atividades sertanistas. ${ }^{347}$ Primeiramente, é preciso notar que ao longo de todo o período analisado houve gastos e a sua intensidade variava de década para década, cada qual muito em prol da realidade específica do local. Em valores reais, percebe-se que os gastos mantiveram praticamente uma tendência de crescimento interrompida em dois momentos importantes na trajetória da própria história da vila, um durante a década de 1690 que presenciou a saída de muitos sertanistas da vila em direção as recém-descobertas minas, e o outro a partir da década de 1710, quando não há mais tanto interesse em expedições sertanistas propriamente ditas, mas sim em setores de produção agrária já que estes eram não só os meios mais seguros para o depósito de recursos financeiros (na maioria adquiridos com a exploração mineira), mas também porque surgiam maiores oportunidades de negócio com a abertura de outros mercados consumidores nos novos povoados que iam se formando nas Minas Gerais, mercados esses muito carentes de produtos de primeira necessidade. No entanto, mesmo sendo dois momentos em que houve uma queda nos investimentos em materiais sertanistas, isto não significa que deixaram de existir: estavam sempre entre as preocupações orçamentárias dos taubateanos.

Tomando como referência os dados expostos nas tabelas, a primeira impressão que se tem é a de que não eram grandes os gastos com o bandeirismo. Talvez seja melhor pensar mais sobre esse indício mesmo porque pode apontar para uma falsa realidade já que nem sempre a metodologia elaborada e a própria documentação permitem a reconstrução do objeto por inteiro, não contemplando todos os aspectos inerentes a ele.

Realmente, considerando-se somente os materiais aglutinados no item "Sertanismo" como parâmetro de referência sobre os custos gerados pelas atividades sertanistas, é de se supor que os gastos despendidos eram muito baixos com relação à riqueza total, ficando

\footnotetext{
${ }^{347}$ Como previamente estabelecido, o item "Sertanismo" é composto por armas de fogo, correntes com colares, pólvora, chumbo e armas brancas.
} 
numa média de $1,40 \%$ dela. Muito baixo, mesmo numa sociedade com poucos recursos materiais.

No entanto, outros tipos de gastos também devem ser computados na lista de despesas. Além dos já citados materiais, outros mais eram necessários numa expedição. Na documentação consultada é possível encontrar várias notas de compromisso de pagamento que descreviam seus motivos. Algumas delas mostram indivíduos tomando por empréstimo animais, objetos cotidianos, dinheiro, alimentos e, principalmente, índios. Consideraram-se aqui estes elementos como sendo "materiais" por ser passível de uma contabilidade, isto é, eram naquele contexto objetos taxados com valores monetários e por isso circulavam via comércio e empréstimos, inclusive os índios.

Com relação à utilização de animais nas viagens, a documentação é econômica em declarações. Na verdade, parece que as entradas sertanistas feitas ainda num período de expedição e desbravamento pouco se utilizaram dos animais, pelo menos nas que partiram da vila de Taubaté, muito provavelmente devido ao difícil caminho que cortava a serra da Mantiqueira, complicando assim a locomoção de animais de grande porte. Porém, durante a década de 1690, após a descoberta das minas de ouro e a formação de núcleos de povoamento no seu entorno, houve uma melhora nos caminhos, possibilitando o tráfego de maior volume. Dessa maneira, as entradas feitas agora, tanto com objetivos expedicionários quanto de comércio, poderiam usufruir da força animal. No inventário de Diogo Teixeira da Cunha, datado de 16 de janeiro de 1699, consta que um tal Francisco Pinto devia ao defunto "uma égua que levou para as minas." 348 Não há referência nem ao valor da dívida nem ao motivo do empréstimo, mas é fato que Francisco foi às minas com uma égua, ou seja, fez uma viagem à região recém povoada utilizando-se de um meio de transporte não muito comum aos sertanistas do passado mas que, a partir desse momento, passou a fazer parte dos itens arrolados entre os gastos efetuados numa viagem.

Os gastos necessários para a organização de uma entrada eram avolumados por alguns objetos considerados básicos, como as armas de fogo, pólvora, chumbo e correntes com colares. Visando contornar a falta de tais materiais e de recursos financeiros iniciais para se por em prática os planos da expedição, muitos alugavam de outras pessoas aquilo que não possuíam, outros ainda faziam acordos com terceiros, oferecendo em troca uma

\footnotetext{
${ }^{348}$ Inventário de Diogo Teixeira da Cunha (1699). Cx: 1691-1699. A.H.M.T.
} 
certa parcela dos frutos obtidos com o empreendimento. Interessante notar que não era apenas o indivíduo que adentrava os sertões o que se beneficiava com os resultados dessas viagens: muitas outras pessoas, que de alguma forma contribuíam para tais empresas, seja direta ou indiretamente, tinham retorno lucrativo, ora sob a forma monetária, ora em espécie - índios ou ouro.

Devido às entradas sertanistas terem sido ações de caráter violento, já que percorriam regiões pouco conhecidas e muitas vezes povoadas por tribos indígenas bastante hostis, pode-se dizer que carregavam em si aspectos tipicamente militares, que podem ser percebidos tanto nas formas de conduta como na posse das armas de fogo. Estas eram extremamente necessárias para a sobrevivência em terras onde as relações humanas ainda se encontravam conflitantes. Dessa maneira, são muitas as referências na documentação compulsada sobre as negociações de armas.

Consta no inventário de Francisco de Morais, feito em 24 de junho de 1660, que ele devia $2 \$ 000$ réis de uma pistola que comprou de Gaspar de Oliveira e mais $8 \$ 000$ réis a Manoel de Linhares pelo aluguel de uma espingarda "que o defunto levou para o sertão."349 Outro que precisou alugar uma arma de fogo foi Baltazar Fragoso que, como declara Manoel de Vasconcelos em seu testamento, datado de 1 de dezembro de 1702, lhe custou seis oitavas de ouro em pó. ${ }^{350}$ Veja-se que as circunstâncias que envolviam as entradas sertanistas levavam a uma dinamização econômica da vila, onde uns e outros negociavam objetos de interesses próprios, colocando em prática com isso um transbordamento participativo da sociedade que poderia estar de fora do âmbito sertanista.

Mais uma prova de que muitos sertanistas não dispunham do material básico para a participação nas entradas é o que se encontrou no inventário de José Cubas Raposo. Este documento é muito interessante porque foi feito ainda durante as investidas no sertão dos Cataguás, onde José foi morto. Está registrado que tal documento chegou do sertão aos 23 de agosto de 1685 juntamente com os pertences do defunto. Entre muitos índios capturados e bens pessoais estavam "três espingardas das quais se dará conta delas a seus donos que são alheios e hua que se entregou a Manoel de Góis da Costa que trouxe o dito Francisco

\footnotetext{
${ }^{349}$ Inventário de Francisco de Morais (1660). Cx: 1649-1667. A.H.M.T.

${ }^{350}$ Inventário de Manoel de Vasconcelos (1702). Cx: 1700-1703. A.H.M.T. O testamento encontrase anexado ao inventário.
} 
Correa Lemos que com ela fazem quatro espingardas."351 Não há menção ao valor combinado para a locação das armas, aliás, também é comum de se encontrar negociações que não estipulavam preços mas que ainda assim sugerem um compromisso econômico entre ambas as partes. Em 5 de agosto de 1686, o Capitão Salvador Gil de Siqueira declarou em seu testamento que "Bento da Costa me deve o que ele achar em sua consciência procedido de uma escopeta e um treçado que levou para o sertão sem conchavo nenhum, da escopeta estou entregue depois de ele haver servido dela." ${ }^{, 352}$ Ficou então a cargo do devedor o valor justo a ser pago, situação que pode pesar na definição deste preço para uma tendência mais generosa visto que poderia estar em jogo não apenas uma transação comercial livre de relações pessoais mas também de confiança e amizade.

Já no caso de Francisco Pedroso, a amizade pode ter pesado mais no trato estabelecido com Pedro da Costa, pois como declarou em seu testamento, este, "filho de Siriaco da Costa, tem uma espingarda minha no sertão em seu poder com condição de me dar a própria arma minha sem interesse algum." 353 Este é um exemplo de que nem tudo deve ser visto através de uma ótica econômico-comercial, pois há que se considerar outras vertentes de influências que atuavam sobre as ações dos homens, neste caso, a amizade e a camaradagem podem ter sido o motivo para a não cobrança do aluguel.

Os gastos com os materiais não paravam por aí. Uma vez que o uso das armas de fogo era praticamente obrigatório nas expedições, também não podiam faltar a pólvora e o chumbo, sem os quais as armas de nada serviriam. Sabendo da importância destes materiais, algumas pessoas que os possuíam, com base nas que foram encontradas na documentação analisada, tratavam logo de comercializá-los, ora estipulando um preço em moeda corrente, ora sugerindo o pagamento através de espécies. Era muito comum o estabelecimento de contratos comerciais que antecediam as entradas sertanistas. Os que iam viajar e que precisavam completar o rol de materiais necessários para tanto, procuravam os que possuíam, neste caso, pólvora e chumbo a fim de negociar a aquisição deles. Muitos acordos eram feitos sem nenhum pagamento inicial, ficando, assim, o registro de condições diferentes para a satisfação de ambas as partes nestas relações.

\footnotetext{
${ }^{351}$ Inventário de José Cubas Raposo (1685). Cx: 1678-1689. A.H.M.T.

${ }^{352}$ Inventário do Capitão Salvador Gil de Siqueira (1691). Cx: 1691-1699. A.H.M.T. O testamento encontra-se anexado ao inventário.

${ }^{353}$ Inventário de Francisco Pedroso (1687). Cx: 1678-1689. A.H.M.T. O testamento encontra-se anexado ao inventário.
} 
Ao testar em 20 de outubro de 1660, Manoel Monteiro Bezerra lembrou de um acordo feito a alguns anos antes com Simão Lopes, onde consta ter adquirido "seis arráteis de pólvora com doze de chumbo para levar para o sertão os quais lhe darei um rapaz ou uma rapariga a seu contento e sendo coisa que venha perdido lhe pagarei a pólvora e o chumbo como lhe custou." 354 Nota-se que a prioridade na forma de pagamento era a da entrega de um índio ao gosto do credor e, caso a expedição não rendesse frutos, a quitação seria feita normalmente via dinheiro. No entanto, parece que nenhuma das duas alternativas foi concretizada ainda em vida, pois a quitação dessa dívida só foi feita pelos herdeiros de Manoel após a sua morte, que ocorreu de forma violenta ao ser assassinado, isso oito anos depois de contrair a dívida. Infelizmente não é possível saber o por quê do não pagamento, já que o defunto dispunha de bens suficientes para tal, mas não de maneira abastada.

Também no inventário de Belchior da Cunha, datado de 1686, encontra-se uma menção a este tipo de negócio. Está acostado ao documento um acordo escrito e assinado pelo próprio defunto, onde declara:

Digo eu Belchior da Cunha que é verdade que devo a Francisco Alves oito mil réis em pólvora e chumbo e outras coisinhas que me faz necessário as quais sendo [rasurado] me dê algum remédio hei-lhe de pagar em dois [rasurado] a saber: dois rapazes ou raparigas, quando não haja rapazes ou raparigas de moça ou rapagão a seu contento $e$ sendo coisa que eu não traga nada desta viagem lhe porei os oito mil réis em dinheiro de contado. ${ }^{355}$

Aqui a forma prática muito usada na aquisição de materiais para as entradas é bastante clara. A falta de recursos financeiros iniciais fazia com que alguns indivíduos se endividassem e o crédito, muitas vezes, era obtido com a promessa de pagamento com outro tipo de moeda, no caso o índio, que era muito valorizado devido à sua grande procura. Somente se a expedição fracassasse, a quitação seria feita em dinheiro.

As negociações em torno dos preparativos que antecediam as entradas continuavam em relação a outros objetos. As correntes com colares eram fundamentais para o aprisionamento dos índios caçados, porém nem todos os sertanistas possuíam as suas, por isso buscavam adquiri-las com terceiros. Manoel Coelho de Souza, por exemplo, diz ter recorrido a Gabriel Barbosa de Lima, morador na vila de São Paulo, onde este "me

\footnotetext{
354 Inventário de Manoel Monteiro Bezerra (1660). Cx: 1649-1667. A.H.M.T. O testamento encontra-se anexado ao inventário.

${ }^{355}$ Inventário de Belchior da Cunha (1686). Cx: 1678-1689. A.H.M.T.
} 
emprestou para o sertão uma corrente de três colares." 356 Não menciona valores como condição para o empréstimo, mas provavelmente tenha existido algum, pois esse não era o único trato comercial registrado entre ambos. ${ }^{357}$

A necessidade de uns era o lucro de outros. O capitão Salvador Gil de Siqueira, como consta em seu inventário, vendeu e alugou correntes. Seus herdeiros declararam que um tal João Pedroso devia ao defunto "um rapaz procedido de uma braça de corrente com três colares." Mais uma vez o negócio era acertado tendo como moeda de pagamento o índio escravizado. Em outra passagem do documento esta prática que envolvia os negócios de compra, venda e empréstimos parece demonstrar o seu caráter corriqueiro, o que denota cada vez mais o forte interesse na aquisição da mão-de-obra escrava. Assim está escrito:

Digo eu João Dias de Vergara que é verdade que aluguei uma corrente de três braças com sete colares de Salvador Gil por uma peça posta em povoado a seu contento e quando me recolha para povoado perdido com a mesma corrente lhe farei pago a ele ou este mostrar e por assim se passar na verdade lhe passei este de minha letra e sinal, hoje dez de dezembro de mil e seiscentos e oitenta e oito anos. ${ }^{358}$

De qualquer forma, o dono das correntes lucrava, seja com o fruto das entradas quando havia sucesso no apresamento de cativos, seja com o pagamento em dinheiro, caso o devedor não tivesse conseguido trazer nenhum nativo do sertão.

Se em termos materiais o esforço econômico despendido pelos sertanistas já era considerável, ainda é preciso direcionar a atenção para a aquisição dos alimentos, tão úteis para a subsistência dos integrantes durante suas viagens.

Como sabido, "a garantia de sobrevivência no sertão da América portuguesa dependeu, em grande parte, dos conhecimentos legados pelas culturas nativas", e nesse sentido, os paulistas eram bastante habituados com os costumes indígenas, assimilando grande acervo de técnicas e de conhecimento que ofereciam o suporte necessário para a vivência cotidiana. ${ }^{359}$ A experiência concreta no mundo colonial era o fio condutor que

\footnotetext{
${ }^{356}$ Inventário de Manoel Coelho de Souza (1660). Cx: 1649-1667. A.H.M.T.

357 Há também a menção a dois conhecimentos no valor de cento e cinqüenta patacas que o inventariado devia a Gabriel.

${ }^{358}$ Inventário do Capitão Salvador Gil de Siqueira (1691). Cx: 1691-1699. A.H.M.T.

${ }^{359}$ KOK, Glória Porto. O Sertão Itinerante: expedições da capitania de São Paulo no século XVIII. São Paulo: Hucitec: Fapesp, 2004. p. 76. Para maiores informações sobre a assimilação da cultura indígena por parte dos colonizadores, ver HOLANDA, Sérgio Buarque de. Caminhos e Fronteiras.

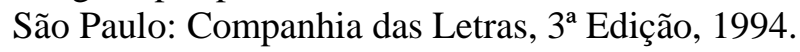


transmitia entre os homens as formas imediatas de comportamento exigidas em diferentes situações, condutas estas que possibilitavam na maioria das vezes a estabilidade vital do indivíduo.

A historiadora Glória Kok se ateve em descrever com riqueza de detalhes as dificuldades que assolavam os sertanistas durante suas incursões. Com evidente influência indígena e "com o intuito de evitar o triste desfecho da fome, os paulistas que se internavam no sertão praticavam a caça sempre que a ocasião permitisse." ${ }^{~} 60$ No rol dos animais consumidos estavam os pássaros de diversas espécies ${ }^{361}$, macacos, pacas, capivaras, veados, tamanduás, antas, porcos-do-mato e uma variedade de peixes. Estavam também entre as preferências do sertanista as raízes, as frutas, o palmito e o mel. Cada item com o seu sabor, ora sendo apreciado, ora sendo repudiado. ${ }^{362}$

Todavia, a descrição de tantas opções de alimentos não significava que a fome não fizesse parte das dificuldades diárias no sertão. Na verdade, a fome era uma preocupação que espreitava o sertanista e que gerava muitos problemas, alguns deles fatais. Taunay, em seus Relatos Sertanistas, descreveu inúmeras ocasiões que abarcavam a vida sertaneja, inclusive a tensão condicionada pela escassez de alimentos. Num episódio em que faltou alimento, durante a longa viagem entre São Paulo e Minas que consumia cerca de 30 a 40 dias de jornada,

houve tal que matou ao seu companheiro por lhe tomar com a tenaz de pau uma pipoca de milho que do seu borralho saltou para o do outro dos poucos grãos que cada um tinha para alimentar a vida naquele dia, aprovando-se por este caso como realidade o provérbio comum de que a fome não tem lei. ${ }^{363}$

Buscando evitar este tipo de fato, muitos homens que percorriam longas estradas procuravam combater a carestia levando consigo alimentos antecipadamente preparados, o que constituía mais um item na lista dos gastos com as entradas. Outro artifício praticado era a plantação de alimentos no curso dos caminhos que levavam às minas, isto é, "com a continuada frequentação da selva, a certa distância dos rios, nas proximidades das veredas e

\footnotetext{
${ }^{360}$ KOK, Glória Porto. Op. cit. p. 76.

${ }^{361}$ Como araras, arapirangas, canindés, jacus, macucos, patos, biguás, tabayayás, guraputepoca, gurátayaçus, socós guaçus, colhereiros, aracuãs, mutuns, trocazes, picacurovas, juritis, pairaris, tucanos, gurapongas e quero-quero.

${ }^{362}$ Sobre as opiniões de muitos viajantes em relação às iguarias sertanistas cf. Idem, Ibidem.

${ }^{363}$ TAUNAY, Afonso de E. Relatos Sertanistas. Belo Horizonte-São Paulo: Itatiaia-Edusp, 1981. p. 31.
} 
trilhos, na ida, faziam os sertanistas roças de mantimentos para colherem na volta, nas demoradas expedições que faziam." 364 Nesse sentido, tais "roças de subsistência eram também plantadas pelos sertanistas numa tentativa de ordenar a natureza", ou seja, cada vez mais o homem interferia no processo natural a que estavam sujeitos com intuito de minimizar as situações de fome que constantemente presenciavam e, com a possibilidade de coleta de alimentos que eles mesmos ou outros sertanistas tivessem plantado tempos antes, não só satisfariam as necessidades básicas como também contribuiriam para a queda nos gastos despendidos com a alimentação. ${ }^{365}$

Antonil ao percorrer o roteiro que levava de São Paulo às Minas durante os primeiros anos do século XVIII corrobora a existência destas plantações. Ao transpor um ribeiro chamado na época de "Passa-trinta" e achando-se num lugar denominado de Pinheirinhos, já em terras mineiras, diz o religioso: "E aqui há roças de milho, abóboras e feijão, que são as lavouras feitas pelos descobridores das minas e por outros, que por aí querem voltar. E só disto constam aquelas e outras roças nos caminhos e paragens das minas, e, quando muito, tem de mais algumas batatas." 366 Era comum, então, a existência dessas roças comunitárias ${ }^{367}$, porém, junto com elas também surgiam fazendas onde os sertanistas podiam se instalar e suprir suas necessidades, mas tudo isso com um preço a ser pago, em geral bastante elevado. Continuando a sua narrativa, Antonil reclama com um tom de revolta que em algumas das paragens que existem pelos caminhos

acha-se criação de porcos domésticos, galinhas e frangões, que vendem por alto preço aos passageiros, levantando-o tanto mais quanto é maior a necessidade dos que passam. E daí vem dizerem que todo o que passou a serra de Amantiqueira aí deixou dependurada ou sepultada a consciência. $^{368}$

${ }^{364}$ LUÍS, Washington. Na Capitania de São Vicente. Belo Horizonte-São Paulo: Itatiaia-Edusp, 1980. p. 189.

${ }^{365}$ KOK, Glória Porto. Op. cit. p. 85.

366 ANTONIL, André João. Cultura e Opulência do Brasil. $3^{\text {a }}$. Ed. São Paulo: Editora da Universidade de São Paulo, 1982. p. 182. Sua obra teria sido escrito, como acredita Taunay, por volta de 1709 e 1710 .

367 "Ao longo dos caminhos percorridos, plantavam roças de subsistência, que iam colher ao voltar ou que deixariam para outros sertanistas usufruírem. A presença de tais roças é constante nos roteiros da penetração paulista." SOUZA, Laura de Mello e. "Formas Provisórias de Existência: a vida cotidiana nos caminhos, nas fronteiras e nas fortificações." In: SOUZA, Laura de Mello e (org.). História da Vida Privada no Brasil: cotidiano e vida privada na América portuguesa. Vol. I. São Paulo: Companhia das Letras, 1997. p.47-48.

${ }^{368}$ ANTONIL, André João. Op. cit. p. 183. 
A reclamação do religioso faz sentido, pois, acerca do contexto em que tais palavras foram escritas, esse tipo de negócio era muito promissor visto que a grande circulação de pessoas por muitos caminhos desprovidos de recursos naturais aumentou a procura por alimentos manipulados pelos próprios homens. Aliás, “acrescenta-se à escassez de recursos naturais, a falta de provisão dos mineradores, mais preocupados em encontrar ouro do que em fazer suas roças. Essa situação de carestia provocou vertiginosa subida nos preços dos alimentos. ${ }^{\text {,369 }}$ Enfim, a instalação de pessoas interessadas no cultivo de alimentos em terras pelas quais cortavam os caminhos que levavam às minas ou em regiões próximas das lavras mostra que as roças eram definitivamente um negócio muito rentoso e capaz de movimentar uma rede econômica e populacional intimamente ligada a esse empreendimento.

Uma dessas roças pertencia a Francisco Rodrigues Moreira, habitante de Taubaté, inventariado em 1716. Seus herdeiros declararam que "no caminho das minas em a paragem chamada Pinheirinho [possuiam] uma légua e meia de sertão de terras de testada com légua e meia de sertão e nas quais terras está um sítio com casas de três lansos, paredes de mão cobertas de palha, com mantimentos." 370 Provavelmente, tal sítio encontrava-se na mesma paragem a que se referia Antonil. A importância deste imóvel, juntamente com seus mantimentos, conferiu-lhe uma avaliação de seu valor bastante considerável, cerca de 1:400\$000 réis. É impossível determinar a produção, muito menos a quantidade comercializada e seus rendimentos, mas supõe-se que os lucros obtidos fossem satisfatórios. Em outro documento menciona-se uma dívida no valor de não menos que $48 \$ 000$ réis em que José Dias de Carvalho devia ao Coronel Domingos Rodrigues da Fonseca "assistente nas minas procedidos de mantimentos que o inventariante comprou."371

Também bastante interessados nas terras próximas dos movimentados caminhos, Manoel Moreira de Brito e Antonio Raposo Barreto filhos do capitão Serafino Correa, deviam ao dito capitão 1:400\$000 “de um sítio que compraram nas Carrancas, caminho das minas", terras que "se não sabe a quantidade nem seu valor", mas que mesmo assim pareciam ser extremamente atraentes. ${ }^{372}$

\footnotetext{
${ }^{369}$ KOK, Glória Porto. Op. cit. p. 87.

${ }^{370}$ Inventário de Francisco Rodrigues Moreira (1716). Cx: 1716-1719. A.H.M.T.

${ }^{371}$ Inventário de Isabel da Rosa (1716). Cx: 1716-1719. A.H.M.T.

${ }^{372}$ Inventário do Capitão Serafino Correa (1717). Cx: 1716-1719. A.H.M.T.
} 
Para além da constatação de que os gastos com os alimentos também engrossavam o peso financeiro despendido por aqueles que participavam das entradas sertanistas, e que, por outro lado, diversas pessoas lucravam com os frutos de suas roças, os exemplos acima mostram que a própria fixação de sertanistas em sítios estáveis voltados a atividades econômicas que não sejam a da caça de índios e nem a da mineração era um fenômeno bastante comum. Buscando confrontar a antiga concepção de que os bandeirantes paulistas eram tradicionalmente ligados à mobilidade e à itinerância, e que só se fixaram em territórios conquistados após as descobertas auríferas ocorridas na década de 1690, ainda assim somente se a exploração mineira justificasse a instalação, Márcio Santos defende que o caráter plástico dos paulistas possibilitou a adaptação destes em diferentes situações geográfico-espaciais que em grande proporção contribuíam para o exercício de atividades econômicas, neste caso, não ligadas à exploração metalífera. Dessa maneira, a mudança do padrão de exploração dos bandeirantes paulistas, da mobilidade vista na caça de índios para a fixação em povoados, não significa que eles estivessem diretamente envolvidos com as lavras, consideradas pela historiografia como a única atividade compensadora; mas que havia outros ramos também economicamente vantajosos capazes de incentivar a instalação de sítios, como a pecuária e a produção de alimentos em geral. ${ }^{373}$

Peça fundamental na execução das viagens, a presença do índio era inevitável para o bom funcionamento da empreitada devido não apenas ao uso da força humana, muito eficaz num confronto bélico ou na utilidade com o carregamento de mantimentos e materiais, mas principalmente como guias, já que muito se aproveitava do conhecimento geográficoespacial dos nativos, além das próprias formas de sobrevivência e de contato com outras tribos.

Apesar de a História ter consagrado muitos nomes de bandeirantes paulistas como elementos centrais das entradas sertanistas, considerando-os responsáveis diretos por tudo aquilo que veio a acontecer, existia por trás deles toda uma estrutura multifacetada que aproximava em seus movimentos pessoas de diferentes níveis econômicos e sociais. A hierarquia, nesse contexto, era a maneira mais viável para o bom relacionamento, tanto horizontal como vertical. Nesse jogo de relações a grande massa humana sobre a qual

373 Cf. SANTOS, Márcio. Bandeirantes Paulistas no Sertão do São Francisco: povoamento e expansão pecuária de 1688 a 1734. São Paulo: Editora da Universidade de São Paulo, 2009. 
estava assentada a bandeira era composta justamente por aqueles que se econtravam na ponta inferior vertical de tal hierarquia, os índios escravizados.

Ao se tomar conhecimento de que "a grande maioria dos integrantes de uma bandeira paulista era constituída por escravos indígenas" ${ }^{\text {374 }}$, deve-se também considerar o peso econômico que isso acarretava. Devido ao grande volume de índios nas expedições talvez seja lícito considerá-lo financeiramente como sendo o de maior comprometimento nos gastos dos sertanistas. Seria interessante pensar um pouco nos problemas que isso poderia gerar visto que levar para o sertão uma parcela dos índios de seu próprio patrimômio não só significava colocar em risco a perda dos mesmos como também significava deslocá-los dos afazares cotidianos necessários para a sobrevivência da família, isto é, retirá-los dos trabalhos agrários que eram as atividades típicas de que se ocupavam para se embrenharem nos matos por tempo indeterminado, envoltos nos perigos comumente encontrados, capazes de resultar em baixas consideráveis. Assim, os gastos eram redobrados. Logicamente que a ocupação de parte da mão-de-obra indígena nas empresas sertanistas não deveria gerar uma desestruturação no sistema produtivo local, mesmo porque eram as mulheres que mais se destacavam no trabalho agrário, e estas raramente iam para o sertão.

Muitos dos sertanistas que pretendiam se aventurar não possuiam o cabedal humano necessário e, por isso, buscavam tratar com aqueles que o disponibilizavam pela via da compra ou do empréstimo. Assim como visto para as aquisições de armas de fogo, pólvora, chumbo e correntes, eram variadas as formas de negociação, encontradas na documentação consultada, que visavam adquirir a mão-de-obra necessária. A compra e o empréstimo eram as maneiras mais comuns. Isabel Rodrigues, mulher que foi de João Martins, declarou no inventário de seu marido, feito no ano de 1660, que ele devia ao capitão Salvador Pires de Medeiros, além de "uma espingarda de seis palmos que dizem haver dera por doze mil réis no sertão (...) mais um moço carpinteiro que levou para o sertão contra sua vontade e sem sua ordem". A viúva também manifestou mais “dois negros que o dito capitão emprestou ao defunto para levar ao sertão em sua companhia." 375 Interessante passagem pois, como se vê, além da compra de materiais, havia os empréstimos que, apesar de não constar o valor,

\footnotetext{
${ }^{374}$ KOK, Glória Porto. Op. cit. p. 47.

${ }^{375}$ Inventário de João Martins (1660). Cx: 1649-1667. A.H.M.T.
} 
eram taxados. Curioso foi o "rapto" do tal carpinteiro. Todos esses empréstimos estão arrolados no inventário entre o título das "dívidas que o defunto deve", isto é, fazem parte das despesas por cuja quitação os herdeiros eram responsáveis.

Sem desconsiderar os laços de amizade e camaradagem, aspectos esses importantíssimos numa relação de confiança, os empréstimos muitas vezes eram uma maneira de se obter vantagens para aqueles que não se envolviam diretamente nas entradas sertanistas. Seja através do pagamento em dinheiro, seja através do pagamento em espécie, muitos bandeirantes se comprometiam em retribuir o "favor" recebido, e para os que cediam os índios restava aguardar o resultado da expedição, certo de que, de uma forma ou de outra, receberia o prometido. Esta reciprocidade de ações era parte fundamental para a formação e manutenção dos chamados "clãs". Como era uma prática corriqueira, Isabel da Cunha não se recusou a emprestar uma de suas negras da terra a Jerômino da Veiga, um parente morador em São Paulo. Entretanto, em seu testamento, Isabel não deixou de registrar a decepção com tal negócio dizendo que Jerônimo ao visitá-la em Taubaté e dali "indo para o sertão me pediu uma negra emprestada a qual partiu para o sertão dizendo-me que quando a minha moça morresse em seu poder me daria duas por ela a qual moça é morta no sertão em seu poder e passando do sertão para São Paulo se não avistou comigo." ${ }^{376}$ A tentação da proposta e talvez a proximidade social sejam as causas da crença que Isabel depositou em Jerônimo ao fechar o acordo que, até sua morte, não havia sido cumprido por parte deste. Mas de qualquer forma, percebe-se que os empréstimos de índios eram práticas bastante úteis tanto para os que precisavam de mão-de-obra como para aqueles que desejavam tirar proveito material e financeiro deste contrato. Aliás, é possível que, a fim de evitar maiores explorações por parte dos credores, muitos sertanistas buscassem adquirir recursos junto ao grupo social do qual se viam mais próximos, no caso, os seus parentes.

Devido à importância dessas relações econômico-comerciais entre pessoas, com ou sem laços afetivos, relações estas que foram bastante significativas no processo de montagem e execução das bandeiras, procurar-se-á, a partir de agora, melhor analisá-las.

\footnotetext{
${ }^{376}$ Inventário de Isabel da Cunha (1683). Cx: 1678-1689. A.H.M.T. Infelizmento não foi possível identificar o grau de parentesco, pois o documento está rasurado, permitindo apenas a leitura do seguinte trecho: "Declaro mais que vindo um [...] meu de São Paulo." Apesar disso, tudo indica que seja um parente.
} 
Enfim, pôde ser constatado através da documentação compulsada que, uma vez sendo obrigatória a posse e o uso de alguns materiais pelos sertanistas, os gastos necessários com a montagem de uma expedição não eram pouco consideráveis visto que muitos homens que desejavam partir para o sertão e não dispondo de recursos recorriam a outras pessoas mais abonadas a fim de adquirirem empréstimos suficientes para a realização desta jornada.

Vale lembrar também que os gastos com o bandeirismo iam além dos materiais, já que se tratava de homens comuns, com suas limitações físicas e mentais. Não são poucas as referências às dificuldades enfrentadas pelos sertanistas constantemente atingidos por doenças, fome, sede, cansaço, saudade, animais selvagens, índios hostis, etc. Se não bastasse todos estes obstáculos enfrentados no sertão, a volta para casa também poderia acarretar problemas. Foi o caso de Luis Coelho, que voltando do sertão soube que sua mulher, Bernarda Rodrigues do Prado, falecera e que, indignado, reclamava que em sua casa

faltavam muitos bens e muitos mantimentos assim roças de mandioca como quantidade de milho e feijão e mais mantimentos e criações de porcos e que vindo do sertão achou a casa limpa e tudo mais destruído pelo que protestava por quem direito for sobre debaixo de tudo o que neste protesto alega contra quem de direito for em nenhum tempo até passar tempo de cobrar os ditos bens visto serem bens de seus filhos menores. ${ }^{377}$

O suporte religioso também era extremamente necessário no cotidiano colonial, principalmente para aqueles que adentravam o sertão. Muitos são os registros que testemunham atitudes religiosas que antecediam as perigosas expedições e que também eram usadas como forma de negócio, bastante lucrativo por sinal. Consta no inventário de José Cubas Raposo, feito em 7 de agosto de 1685, uma nota que exprime as seguintes informações:

João Faria Fialho, sacerdote do hábito de São Pedro que indo o defunto José Cubas para o sertão dos Berigassus, pediu a ele suplicante lhe dissesse uma missa cada mês por sua tenção para que Nosso Senhor lhe desse boa viagem e que vindo de volta com a gente nova lhe daria de esmola das ditas missas um bom rapaz ou rapariga com a desempedida de pai e mãe; não havendo rapaz ou rapariga desempedida lhe daria um

${ }^{377}$ Inventário de Bernarda Rodrigues do Prado (1672). Cx: 1668-1677. A.H.M.T. Sobre a complexa vida no sertão ver KOK, Glória Porto. Op. cit. 
bom rapaz ou uma boa moça e sendo caso viesse sem remédio do gentio novo perderia ele suplicante as esmolas das ditas missas, e por quanto da tal viagem consta haver trazindo muita gente que Manoel de Siqueira, irmão do dito defunto, a pôs em povoado e é testemunha dessa verdade. ${ }^{378}$

Se por um lado a falta de recursos financeiros era um empecilho para a participação no movimento bandeirista, por outro existiam diferentes ferramentas que viabilizavam a inserção de pessoas despossuídas de recursos próprios.

Era muito comum a associação entre pessoas interessadas nos frutos das expedições. Cada lado entrava com o que dispunha naquele momento. Uns com financiamentos através de dinheiro, outros com materiais e mão-de-obra e, por fim, outros com o próprio serviço. Luiza Volpato resume muito bem essa realidade:

a montagem de uma bandeira era, conseqüentemente, um empreendimento que demandava investimento de capital. (...) Existia também o caso de bandeiras serem armadas por indivíduos que não participavam efetivamente da expedição, mas apenas de sua montagem e de seus lucros. Estes eram os armadores das bandeiras, aqueles que investiam o capital para a armação da expedição e que estabeleciam contratos com outros, que participavam efetivamente da empreitada mas não dispunham de recursos para se armarem as suas próprias custas. ${ }^{379}$

A existência dessas diferentes formas de negociações permitia que os assuntos referentes às expedições extrapolassem o próprio círculo dos sertanistas, isto é, o investimento e a lucratividade obtida com as entradas não atingiam apenas aqueles que estavam inseridos diretamento na trama bandeirista, ao contrário, muitas pessoas que se ocupavam com outras atividades econômicas podiam estar na esfera de influência gerada a partir deste movimento.

O baixo custo relativo dos gastos individuais, pelo menos em relação à despesa total com a montagem da expedição, a não preocupação com todos os problemas acarretados pela organização e execução desta, e a possibilidade de um alto grau de retorno financeiro eram os incentivos encontrados na eventual participação em tais empreendimentos. Dessa maneira, muitos documentos atestam para o caráter comum dessas "associações" de capital onde cada um dos lados comprometia-se a entregar uma quantia, um material ou os próprios serviços em prol do sucesso da empreitada. Assim como as equivalências nos

\footnotetext{
${ }^{378}$ Inventário de José Cubas Raposo (1685). Cx: 1678-1689. A.H.M.T.

${ }^{379}$ VOLPATO, Luiza Rios Ricci. Entradas e Bandeiras. São Paulo: Global, 1985. p. 58.
} 
investimentos, a divisão dos possíveis frutos também era pré-definida, cabendo a cada um dos interessados uma parcela do lucro obtido.

Além dos objetos que precisou pegar emprestado ${ }^{380}$, Belchior da Cunha também recorreu ao capitão Manoel Garcia Velho a fim de adquirir "nove patacas em dinheiro de contado do que me emprestou os quais lhe pagerei a volta do sertão", e também a Salvador Machado "três mil e seiscentos réis em dinheiro de contado os quais lhe pagarei a volta desta viagem que faço agora um rapaz pagem ou rapariga dando-me Nosso Senhor remédio", e caso nada consiga, "lhe pagarei quatro mil réis." 381 Percebe-se que o endividamento foi grande nesse caso, onde o devedor se compreteu financeiramente com mais de uma pessoa, e mais, note-se a imposição de juros como condição do empréstimo, tornando-o assim um negócio seguro e vantajoso, pelo menos para os credores, já que para os herdeiros de Belchior nada restou de herança, ou pior, ficaram com o prejuízo de $78 \$ 780$ réis de dívidas.

Mais sorte teve a viúva e os filhos do capitão Miguel de Almeida Cunha que puderam usufruir dos resultados positivos oriundos dos negócios que o dito capitão havia feito antes de morrer. O seu inventário é uma testemunha concreta do seu envolvimento com o sertanismo taubateano, no qual está registrado não apenas a grande posse de índios cativos - algo acima de uma centena - mas também o investimento financeiro e material feito pelo menos em duas entradas, infelizmente não foi possível identificar a data destas, porém presume-se que devem ter sido efetuadas mais próximo da morte do capitão. Ao prestar contas dos bens da família, declarou a viúva, Maria Vieira, que

o defunto seu marido em sua vida tinha botado para o sertão duas armações a meias uma com João da Veiga com quatro negros e uma espingarda e um tacho e outra armação com Jerônimo da Veiga com oito negros e uma corrente e duas espingardas e um tacho e o mais necessário que se pede para o sertão e que não faria partilhas até virem os ditos seus armadores e que em vindo os ditos do sertão se farão as partilhas entre ela e seus filhos e que os negros que andavam no sertão vão lançados neste inventário. ${ }^{382}$

A declaração acima é muito rica em suas palavras porque esclarece alguns aspectos que eram bastante comuns no universo sertanista. Primeiro, deduz-se que a chamada

${ }^{380}$ Belchior já foi citado quando se tratou dos empréstimos que envolviam os materiais utilizados nas entradas sertanistas como a pólvora e o chumbo. Cf. página 146.

${ }^{381}$ Inventário de Belchior da Cunha (1686). Cx: 1678-1689. A.H.M.T.

${ }^{382}$ Inventário do capitão Miguel de Almeida Cunha (1687). Cx: 1678-1689. A.H.M.T. 
“armação" era o equivalente à montagem de uma bandeira, pois mesmo que os objetivos fossem diferentes (caça de índios, busca por metais preciosos, expedição de reconhecimento, etc) a variação nas denominações de tais entradas não traduzia as motivações implícitas do movimento em si, muito menos as mudanças no padrão de execução delas. Neste caso, o capitão Miguel de Almeida Cunha investiu grande quantidade de material em duas armações com claros objetivos de caça de índios, nas quais estavam envolvidos João da Veiga e Jerônimo da Veiga, possivelmente irmãos, chamados de "armadores". Armador aqui, aliás, não era o investidor e sim o que comandava a armação. O segundo aspecto que deve ser ressaltado é a associação empreendida no negócio sertanista. Enquanto havia de um lado a disponibilização de recursos materiais, do outro lado havia a prestação do serviço, e esta divisão de responsabilidades corresponde a uma associação previamente estabelecida, inclusive em seus resultados. Ao mencionar que seu marido havia botado duas armações "a meias”, a viúva quis dizer que ficou acertado que a metade dos frutos gerados pelas ditas armações pertenciam a ele. Com a volta de Jerônimo da Veiga, coube por direito aos herdeiros do inventariado dez peças escravas, além da devolução do material emprestado. Já com relação à entrada de João da Veiga nada foi registrado.

É grande a quantidade dos dados encontrados na documentação compulsada que exprimem essa forma de associação entre partes, visando à organização de uma entrada sertanista e, por isso, seria desgastante demais arrolá-los um a um. No entanto, é válida a citação de algumas passagens que, além de ratificarem a prática que havia em se estabelecer contratos em torno das bandeiras, mostram também o costume de envolver os próprios familiares nas empreitadas.

Verificou-se a participação de muitos indivíduos ligados por diferentes graus de parentesco numa mesma organização contratual sertanista. Esta constatação pode ser feita muito em função da ênfase dada pelos testadores ou pelos inventariantes na proximidade familiar existente entre os membros dos negócios estabelecidos. Como se verá, era bastante ampla a rede de influência entre parentes envolvidos nas entradas sertanistas, ora ficando no núcleo familiar, ora extravazando as cercas dos sítios e os muros das residências.

O capitão Salvador Gil de Siqueira, por exemplo, declarou em testamento, datado de 5 de agosto de 1686, que "fui para o sertão com armação de meu primo Sebastião de 
Siqueira para partir com ele a metade" ${ }^{, 383}$. Outro que tratou de negócios sertanistas em família foi Manoel de Figueiredo que disse, na ocasião da morte de sua esposa, ter feito uma armação com seu genro Antonio Marques. ${ }^{384}$

Apesar da ligação econômica entre parentes mais distantes, a manutenção desses negócios nos núcleos familiares, parece ter sido a preferência entre os sertanistas que optavam pelo controle total dos rumos tomados em prol da organização e execução das entradas. Não há dúvida para Monteiro que, "na ausência de dispositivos institucionais que garantissem tais investimentos, parecia mais seguro confiar em parentes."385

"Declaro que eu tenho dois filhos no sertão, Manoel de Góis e Gabriel de Góis por minha conta, e assim trazendo os [rasurado] salvamento com remédio entrará tudo no montemor para se fazer as partilhas entre todos os meus herdeiros, e conforme as peças que trouxer, de cada dúzia lhe darão três de seu trabalho", assinalou o capitão Domingos Gomes em seu testamento ditado em 19 de fevereiro de $1671 .^{386}$ Observando este trecho, fica clara a maneira como funcionava a inserção dos filhos nas expedições e como eram retribuídos pelos serviços prestados. Na verdade, pensando mais detalhadamente, para estes que receberam suas respectivas partes no lucro da empreitada, o ganho não ficava somente nisso, uma vez que o restante dos lucros que “entrará tudo no montemor" será repartido entre os herdeiros após a morte do dito capitão, ou seja, os filhos sertanistas receberão indiretamente mais uma parte daquilo que foram buscar no sertão. O não comprometimento financeiro com terceiros, a solidez na parceria e o aumento da riqueza familiar talvez sejam os principais motivos do envolvimento de filhos nas bandeiras.

Os testamentos são bastante úteis para a obtenção de informações sobre os tratos organizados no âmbito familiar. Neles, é possível encontrar depoimentos que explicitam, pelo menos em parte, a estrutura comercial da bandeira, isto é, alguns registram a responsabilidade do investimento e outros o direito de posse dos resultados.

Em 16 de abril de 1704, o capitão Antonio Delgado de Escobar declarou em seu testamento que "sendo ainda solteiro meu filho João Delgado de Escobar o mandei ao

\footnotetext{
${ }^{383}$ Inventário do Capitão Salvador Gil de Siqueira (1691). Cx: 1691-1699. A.H.M.T. O testamento encontra-se anexado ao inventário.

${ }^{384}$ Inventário de Sebastiana de Torres (1671). Cx: 1668-1677. A.H.M.T.

${ }^{385}$ MONTEIRO, John Manuel. Op. cit. p. 86.

386 Inventário do Capitão Domingos Gomes (1671). Cx: 1668-1677. A.H.M.T. O testamento encontra-se anexado ao inventário.
} 
sertão com negros e aviamentos e gastos de minha casa da qual viagem trouxe cinco almas". ${ }^{387}$ Isto posto, entende-se que ditando estas palavras o testador buscava ratificar o seu direito sobre os cinco índios escravizados alegando que quando seu filho os capturou era ainda solteiro, ou seja, estava sob sua tutela, e mais, a viagem teria ocorrido com o suporte material e humano da "minha casa".

Também visando justificar o uso de bens relativos à fazenda, o capitão Manoel da Costa Cabral fez questão de relatar que "em certo tempo mandei para as minas um negro da terra em companhia de meu filho Vitorio de Arruda para me trazer algum ouro e lá morreu este negro, peço pelo amor de Deus a meus herdeiros não falem nele", ${ }^{388}$ isto é, isenta o dito filho da responsabilidade pela perda de um bem da família e pede para que os outros herdeiros não mais toquem no assunto. Pelo tom das palavras, parece que o fato da morte do índio e a consequente diminuição da riqueza não agradou o restante da família.

Investimento feito pela fazenda significava que os frutos a ela pertenciam. Como exemplo interessantíssimo deste raciocínio, destaca-se o testamento do capitão Domingos Rodrigues do Prado, feito no ano de 1715 em Taubaté. Além do seu forte envolvimento nas entradas, também inseriu seus filhos no movimento sertanista. Começa por citar que três dos seus filhos, Domingos Rodrigues do Prado ${ }^{389}$, Salvador Rodrigues do Prado e Euzébio Rodrigues do Prado se encontravam, “nas minas e sempre lá andaram com cabedal e peças do monte", quer dizer, todos os três estavam a serviço do pai, já que receberam investimento material e humano da família. Nada de novo nestas linhas até aqui. Entretanto, mais adiante reclama o pai de que

estes três filhos além de sempre deverem ao monte há quatro anos ou
cinco que me fugiram para as minas do ouro e nos levaram sete negros e
uma negra a saber Severino, José do gentio da terra es mais escravos e
com estes descobriram minas novas de ouro no Rio de Paraipitanguy e
nelas com os negros que do nosso monte levaram e tem [rasurado] e

387 Inventário do Capitão Antonio Delgado de Escobar (1708). Cx: 1704-1717. A.H.M.T. O testamento encontra-se anexado ao inventário.

${ }^{388}$ Inventário do Capitão Manoel da Costa Cabral (1711). Cx: 1704-1717. A.H.M.T. O testamento encontra-se anexado ao inventário.

${ }^{389}$ Este é o famoso sertanista Domingos Rodrigues do Prado que além de ser conhecido pelos seus descobrimentos, com destaque para a mencionada vila de Pitangui, também figura entre os paulistas de gênio forte capaz de enfrentar as autoridades reais. Esta fama se espalhou devido ao seu envolvimento em rixas e levantes. Para maiores informações Cf. FRANCO, Francisco de Assis Carvalho. Dicionário de Bandeirantes e Sertanistas do Brasil. São Paulo: Comissão do V Centenário da Cidade de São Paulo, 1954. p. 309, 310, 311 e 312. 
aumentado os quais por nossas mortes devem repor ao monte assim as peças como os lucros delas para se repartirem por todos os mais herdeiros. ${ }^{390}$

O pai não estava nada satisfeito com as atitudes dos filhos, não com relação ao sucesso alcançado no achamento de novas minas, mas sim com a falta de contato e, principalmente, com o não retorno financeiro, coisa que fazia parte de um contrato estabelecido entre os membros da família. Aliás, é possível que o deslumbramento com as minas encontradas tenha causado um rompimento contratual nos negócios e na família, uma atitude desonesta, uma situação muito similiar à que se referia Antonil quando falava das mudanças do comportamento humano diante de oportunidades vantajosas. ${ }^{391}$

A intencionalidade econômica das entradas sertanistas é claramente exposta no seguinte trecho de um documento encaminhado ao juiz de órfãos da vila de Taubaté anexado ao inventário de José de Castilho, falecido no ano de 1684. Está escrito o seguinte:

Diz Manoel de Castilho, órfão que ficou de José de Castilho, seu pai legítimo, que a ele deu seu padrasto Antonio Rodovalho gastos para o sertão sem interesse nenhum de pólvora e chumbo e o mais necessário, $e$ quer ele suplicante ir ver se pode aumentar a fazenda de seus irmãos $e$ sua, e para seguir viagem lhe falta dois negros para o acompanhar $e$ como vai negros dos órfãos. ${ }^{392}$

Com o objetivo de "aumentar a fazenda", essa é a alegação feita por Manoel de Castilho para justificar a utilização dos bens, no caso dois negros, pertencentes aos seus irmãos que, aliás, também seriam beneficiados com os resultados da jornada. A morte do pai, o patriarca da família, abria oportunidades para os herdeiros iniciarem suas próprias empresas, porém, em muitos casos, era preciso fazer um acordo entre os irmãos ou mesmo solicitar ao tutor dos incapazes o empréstimo de recursos necessários. De qualquer forma, o que se vê é a re-estruturação dos contratos familiares em torno do movimento sertanista.

Já que a prática da associação em torno dos negócios sertanistas entre parentes era muito comum, seria interessante mostrar a intensidade desta. Para tanto, basta observar dois exemplos selecionados entre a documentação que podem ser considerados a prova de tal realidade.

\footnotetext{
${ }^{390}$ Inventário do Capitão Domingos Rodrigues do Prado (1715). Cx: 1709-1715. A.H.M.T. O testamento encontra-se anexado ao inventário.

${ }^{391}$ Cf. página 149 desta dissertação.

392 Inventário do José de Castilho (1684). Cx: 1678-1689. A.H.M.T. O mencionado documento encontra-se anexado ao inventário.
} 
Se a regra era a utilização dos bens da família para o custeio e execução das expedições, a não-utilização deles, isto é, a exceção à regra devia ser afirmada para que não houvesse dúvidas quanto à origem de tais recursos a fim de evitar conflitos entre diferentes partes. Foi o que fez Antonia Furtada ao registrar em seu testamento, feito no ano de 1672, que

meu filho Miguel Rodrigues do Prado foi ao sertão dos Tobaiaras a sua custa sem eu lhe dar ajudório nenhum, nem aviamento, que a sua custa foi [rasurado] quatro peças ou o que dela trouxe, todas são suas, peço a seus irmãos não entendo com ele que em minha consciência acho que são suas livres e desenbargadas adquiridas por sua agência e trabalho. ${ }^{393}$

Assim, a mãe declarou oficialmente que tudo o que foi feito pelo filho e o resultado de suas ações, no caso quatro índios escravizados, era dele por direito e que nenhum dos outros filhos deveriam clamar pela partilha dos citados bens. De acordo com John Monteiro, a necessidade de afirmação deste fato significava também o seu caráter incomum, ou melhor, a preferência dos sertanistas pelo uso dos recursos financeiros da família à utilização dos bens próprios. ${ }^{394}$

Também Antonio Vieira da Maia fez questão de mencionar que “os ditos meus filhos acima nomeados [João Vieira da Maia, Matheus Vieira da Cunha e Henrique Vieira da Cunha] foram ao sertão sem eu lhe dar ajudório nenhum." ${ }^{\text {,395 }}$ A fim de evitar problemas com os outros irmãos e mesmo com a justiça, uma vez que todos os bens do inventariado iam para o rol de partilhas, inclusive os que não estavam em sua posse no momento da morte, este pai se precaveu anotando estas palavras em seu testamento. Portanto, declarar que não houve a utilização da riqueza familiar em alguma empresa sertanista significava abdicar dos direitos sobre os possíveis frutos dela.

Como visto até aqui, o movimento sertanista era, em seu formato prático, a aglutinação de um grande número de recursos materiais e humanos alicerçado num mesmo suporte objetivo e estabilizado pela via dos contratos pré-definidos, tanto os oficiais quanto os não oficiais. Muitos gastos eram feitos nesse contexto, muito se despendia com a

\footnotetext{
393 Inventário de Antonia Furtada (1672). Cx: 1668-1677. A.H.M.T. O testamento encontra-se anexado ao inventário.

${ }^{394}$ Diz Monteiro: "Ao que parece, os filhos esperavam dos pais ajuda material e financeira para as viagens ao sertão. Tão usual deveria ser o socorro paternal nas armações que sua ausência tornavase fato digno de nota." MONTEIRO, John Manuel. Op. cit. p. 87.

${ }^{395}$ Inventário de Antonio Vieira da Maia (1674). Cx: 1668-1677. A.H.M.T. O testamento encontrase anexado ao inventário.
} 
organização e execução das entradas, excessivos esforços eram feitos, esforços esses que iam do âmbito físico ao mental. Agora, as perguntas que ficam são: com todas essas dificuldades, era o sertanismo uma atividade realmente compensadora? Como estavam situados econômica e socialmente os bandeirantes em relação à sociedade em geral? Essas e outras questões serão tratadas nas páginas seguintes.

\subsubsection{Os Sertanistas: um grupo social em destaque}

Apesar do avanço nas recentes pesquisas que contemplam o estudo das características de diferentes grupos sociais ${ }^{396}$, o mapeamento do perfil sócio-econômico dos bandeirantes ainda é bastante confuso. Muitas das concepções elaboradas nas primeiras décadas do século passado ainda estão entre as imagens aceitas como paradigmas de uma realidade sertanista do período colonial, sobretudo paulista.

É demasiadamente grande a dificuldade de se encontrar obras de referência que buscam definir as características dos homens envolvidos com as atividades sertanistas, tanto para São Paulo, como para Taubaté. Certamente, existem aquelas obras que elegeram um ou outro indivíduo como representante do movimento bandeirista, eleição esta que levou em conta os grandes feitos e a fama adquirida de geração em geração. ${ }^{397}$ No entanto, por trás destes havia um considerável contingente que viveu as mesmas experiências, positivas e negativas, daqueles indivíduos tidos como "heróis", mas que não ficaram marcados nas páginas da História.

A intenção aqui é tentar traçar um perfil social e econômico do grupo sertanista da vila de Taubaté. Para tanto foram elaboradas algumas tabelas que expõem a configuração da riqueza do grupo sertanista, inclusive a divisão dela entre os diversos setores de comprometimento da riqueza e a sua equivalência em porcentagem, tudo isso em comparação ao universo econômico do restante da população. As informações obtidas podem ajudar a localizar o posicionamento dos sertanistas dentro do universo social e

\footnotetext{
${ }^{396}$ Como exemplo desses estudos, pode-se citar a obra de Maria Aparecida de Menezes Borrego que analisa os homens envolvidos no negócio mercantil de São Paulo. Cf. BORREGO, Maria Aparecida de Menezes. A Teia Mercantil: negócios e poderes em São Paulo colonial (1711-1765). São Paulo: Alameda, 2010.

${ }^{397}$ Cf. AZEVEDO, Victor de. Manuel Preto: "o herói de Guairá”. Coleção Paulística n ${ }^{\circ} .22$, São Paulo: Governo do Estado, 1983. BARREIROS, Eduardo Canabrava. Roteiro das Esmeraldas: a bandeira de Fernão Dias Pais. Rio de Janeiro: José Olympio, 1979. CORTESÃO, Jaime. Raposo Tavares e a formação territorial do Brasil. Rio de Janeiro: Imprensa Nacional, 1958.
} 
econômico apresentado pela vila taubateana entre as décadas de 1650 e 1720, e entender melhor a lógica da prática sertanista como empreendimento destinado a fins lucrativos.

Tabela 21: Riqueza dos sertanistas em comparação a riqueza geral de Taubaté

\begin{tabular}{lcccccc}
\hline & \multicolumn{3}{c}{$\mathbf{1 6 5 0}$} & \multicolumn{3}{c}{ 1660 } \\
\hline \multicolumn{1}{c}{ Itens } & \multicolumn{2}{c}{ Sertanistas } & \multicolumn{1}{c}{ Geral } & \multicolumn{2}{c}{ Sertanistas } & Geral \\
Rural & $201 \$ 880$ & $51,1 \%$ & $394 \$ 660$ & $121 \$ 430$ & $60,3 \%$ & $201 \$ 330$ \\
Urbano & $9 \$ 600$ & $51 \%$ & $18 \$ 800$ & $12 \$ 000$ & $37,5 \%$ & $32 \$ 000$ \\
Escravo & $2: 439 \$ 000$ & $44,7 \%$ & $5: 456 \$ 000$ & $1: 898 \$ 000$ & $65,9 \%$ & $2: 877 \$ 000$ \\
Ouro & 0 & $0 \%$ & $14 \$ 000$ & $34 \$ 000$ & $64 \%$ & $53 \$ 100$ \\
Prata & $12 \$ 820$ & $100 \%$ & $12 \$ 820$ & $38 \$ 720$ & $60,2 \%$ & $64 \$ 240$ \\
Comércio & $48 \$ 940$ & $77 \%$ & $63 \$ 540$ & 0 & $0 \%$ & 0 \\
P. Vida & $133 \$ 920$ & $50,1 \%$ & $267 \$ 290$ & $78 \$ 880$ & $26,3 \%$ & $299 \$ 140$ \\
Dív. Ativa & $98 \$ 300$ & $58,2 \%$ & $168 \$ 800$ & $382 \$ 160$ & $89,2 \%$ & $427 \$ 980$ \\
Sertanismo & $34 \$ 540$ & $72,8 \%$ & $47 \$ 430$ & $64 \$ 200$ & $73,3 \%$ & $87 \$ 480$ \\
Monte-mor & $2: 979 \$ 000$ & $46,5 \%$ & $6: 394 \$ 020$ & $2: 629 \$ 390$ & $65 \%$ & $4: 042 \$ 270$ \\
Div. Passiva & $546 \$ 749$ & $89,6 \%$ & $610 \$ 003$ & $246 \$ 940$ & $85,3 \%$ & $289 \$ 460$ \\
Monte- & $2: 432 \$ 251$ & $42 \%$ & $5: 784 \$ 017$ & $2: 382 \$ 450$ & $63,4 \%$ & $3: 752 \$ 810$ \\
menor & & & & & & \\
Inventários & 6 & $33,3 \%$ & 18 & 6 & $30 \%$ & 20 \\
\hline
\end{tabular}

Fonte: Inventários (1649 a 1720). Arquivo Histórico Municipal de Taubaté.

As primeiras informações que se devem considerar são as que dizem respeito ao número de inventários dos indivíduos considerados sertanistas dentro da amostra documental existente. Através destes dados é que se poderá traçar uma análise comparativa entre o grau de riqueza e o uso dela entre os homens envolvidos com o bandeirismo e o restante da vila.

Nestas duas primeiras décadas, os indícios apontam que os sertanistas eram a minoria da população, algo em torno de $1 / 3$ dela. ${ }^{398}$ Todavia, a situação de inferioridade não impediu que eles detivessem uma boa parte da riqueza total da vila, cerca de 46,5\% para a década de 1650 e $65 \%$ para a de 1660, ou seja, passava pelas suas mãos uma considerável parcela da economia local que estava distribuída entre os itens levantados e tidos como comuns para uma sociedade de característica colonial. ${ }^{399}$ Destaque para os

\footnotetext{
${ }^{398}$ As informações referentes à população sertanista já foram expostas anteriormente, no gráfico 5 que está na página 127.

${ }^{399}$ São bastante curiosos os números apresentados em relação ao monte-mor. Aqui a porcentagem referente a posse da riqueza pertencente ao grupo sertanista aumentou, mas isso só ocorreu porque a riqueza geral da vila diminuiu e não porque a dos sertanistas tenha se elevado. De qualquer forma, houve a ampliação do controle da riqueza pelos sertanistas. Deve-se atentar para o fato de que se houve a queda da riqueza geral, pelo menos para os sertanistas o prejuízo foi em menor expressão, o que leva a crer que as atividades econômicas exercidas por eles podem ser consideradas as mais seguras.
} 
setores de maior interesse, o rural e o escravo, que formavam os pilares do comprometimento de tal riqueza, tendência esta comum a todos, inclusive aos sertanistas. Nota-se claramente o aumento do interesse por esses setores. Já que a economia local estava assentada na produção agrária, a posse de escravos era uma necessidade vital para o funcionamento do sistema produtivo, e nesse sentido, os sertanistas estavam um passo à frente do restante da população, pois eram eles os responsáveis pela inserção da mão-deobra indígena feita através das expedições de preamento. Isso explica a sua grande posse de escravos.

As dívidas passivas e ativas também têm influência dentro dos interesses apresentados. É impossível não notar a grande porcentagem das dívidas que circulavam por entre os bandeirantes, mostrando com isso que eles não só detinham riquezas depositadas na própria dinâmica da vila como também eram uma importante fonte capaz de disponibilizar recursos financeiros que contruibuíam para a manutenção da estrutura econômica da vila. Além do que, parecem ser elas um setor muito útil para o sistema local, principalmente porque eram responsáveis pela injeção de riqueza por meio da sua mobilidade e fonte de lucros.

De maneira geral, as características econômicas apresentadas pelos sertanistas durante as décadas seguintes não são muito diferentes das que foram vistas até agora, guardadas algumas exceções.

Tabela 22: Riqueza dos sertanistas em comparação a riqueza geral de Taubaté

\begin{tabular}{lcccccc}
\hline & \multicolumn{3}{c}{$\mathbf{1 6 7 0}$} & \multicolumn{3}{c}{$\mathbf{1 6 8 0}$} \\
\hline \multicolumn{1}{c}{ Itens } & \multicolumn{2}{c}{ Sertanistas } & Geral & \multicolumn{2}{c}{ Sertanistas } & Geral \\
Rural & $265 \$ 420$ & $64,1 \%$ & $413 \$ 860$ & $670 \$ 330$ & $49,7 \%$ & $1: 346 \$ 150$ \\
Urbano & $73 \$ 400$ & $73,9 \%$ & $99 \$ 200$ & $126 \$ 380$ & $49,5 \%$ & $255 \$ 080$ \\
Escravo & $3: 729 \$ 000$ & $78,1 \%$ & $4: 770 \$ 000$ & $10: 118 \$ 700$ & $61,5 \%$ & $16: 429 \$ 720$ \\
Ouro & $8 \$ 140$ & $100 \%$ & $8 \$ 140$ & $38 \$ 500$ & $55 \%$ & $70 \$ 000$ \\
Prata & $13 \$ 900$ & $68,4 \%$ & $20 \$ 300$ & $48 \$ 660$ & $63,4 \%$ & $76 \$ 700$ \\
Comércio & 0 & $0 \%$ & 0 & $113 \$ 160$ & $46,3 \%$ & $243 \$ 900$ \\
P. Vida & $118 \$ 500$ & $48,3 \%$ & $245 \$ 220$ & $226 \$ 660$ & $45 \%$ & $503 \$ 280$ \\
Dív. Ativa & $112 \$ 160$ & $56,8 \%$ & $197 \$ 158$ & $395 \$ 160$ & $18,3 \%$ & $2: 155 \$ 088$ \\
Sertanismo & $57 \$ 160$ & $73 \%$ & $78 \$ 220$ & $95 \$ 360$ & $51,6 \%$ & $184 \$ 600$ \\
Monte-mor & $4: 357 \$ 880$ & $74,7 \%$ & $5: 832 \$ 098$ & $11: 833 \$ 710$ & $55,6 \%$ & $21: 264 \$ 518$ \\
Div. Passiva & $850 \$ 371$ & $62,7 \%$ & $1: 355 \$ 451$ & $1: 237 \$ 610$ & $34 \%$ & $3: 638 \$ 100$ \\
Monte- & $3: 507 \$ 509$ & $78,3 \%$ & $4: 476 \$ 647$ & $10: 596 \$ 100$ & $60,1 \%$ & $17: 626 \$ 418$ \\
menor & & & & & & \\
Inventários & 13 & $56,5 \%$ & 23 & 14 & $41,1 \%$ & 34 \\
\hline Fo: Find
\end{tabular}

Fonte: Idem. 
Novamente, a atenção é dada em princípio à quantidade de sertanistas encontrada na documentação pesquisada. A porcentagem correspondente à parcela deles na sociedade taubateana constatada para a década de 1670, que é de 56,5\%, sugere que esta atividade estava em alta a ponto de abranger mais de metade da população, mas, no período seguinte, tal porcentagem volta a cair, mais precisamente, para 41,1\%. Essas variações no tamanho do grupo social envolvido com as atividades sertanistas podem indicar tanto o nível de interesse nesses empreendimentos, como a movimentação humana evidenciada nas constantes idas e vindas dos colonos. Ambas as evidências insinuam a participação direta da vila de Taubaté no processo desbravador acarretado pelas entradas sertanistas, ora mais intensamente, ora menos.

Com relação aos interesses no comprometimento patrimonial, os itens mais procurados e por isso sob forte controle do grupo bandeirante local continuam sendo o setor rural e o escravo, não significando, porém, a abstenção de outros setores que também mostram grande porcentagem de posse por parte desse grupo. Nota-se que, em termos de riqueza, a vila juntamente com o grupo sertanista estava crescendo, isto é, os números reais exibem um aumento considerável na posse e na circulação da riqueza local.

Sobre a posse dos sertanistas, percebe-se que, apesar do aumento de seu montante, houve uma queda na sua equivalência em relação à riqueza total da vila, mas ainda assim tal grupo concentrava $60,1 \%$ da riqueza. O recuo dessa concentração também pode ser visto em quase todos os setores analisados, com a exceção do item "Comércio". Não obstante a queda generalizada, o poder econômico dos sertanistas distribuído em tais setores continua forte, sempre próximo a 50\%, senão acima disso. A ressalva fica por conta das dívidas ativas e passivas, pois ambas sofrem queda vertiginosa, o que pode significar uma maior independência financeira. Entretanto, pensando por outro lado, a queda do controle da riqueza distribuída nos diferentes setores da economia local por parte dos sertanistas denota também a expansão do poder dos não-sertanistas.

Prosseguindo a visualização dos dados, a tabela seguinte marca um momento bastante interessante. 
Tabela 23: Riqueza dos sertanistas em comparação a riqueza geral de Taubaté

\begin{tabular}{lcccccc}
\hline & \multicolumn{3}{c}{$\mathbf{1 6 9 0}$} & \multicolumn{3}{c}{$\mathbf{1 7 0 0}$} \\
\hline \multicolumn{1}{c}{ Itens } & \multicolumn{2}{c}{ Sertanistas } & Geral & \multicolumn{2}{c}{ Sertanistas } & Geral \\
Rural & $281 \$ 920$ & $19,8 \%$ & $1: 423 \$ 440$ & $2: 704 \$ 170$ & $51,6 \%$ & $5: 238 \$ 930$ \\
Urbano & $98 \$ 240$ & $17,7 \%$ & $552 \$ 680$ & $427 \$ 000$ & $26,6 \%$ & $1: 599 \$ 840$ \\
Escravo & $1: 971 \$ 400$ & $22,4 \%$ & $8: 784 \$ 400$ & $18: 665 \$ 000$ & $46,4 \%$ & $40: 153 \$ 120$ \\
Ouro & $16 \$ 250$ & $24,4 \%$ & $66 \$ 450$ & $4: 148 \$ 365$ & $75,4 \%$ & $5: 501 \$ 765$ \\
Prata & $38 \$ 340$ & $23,5 \%$ & $162 \$ 840$ & $392 \$ 940$ & $46,5 \%$ & $843 \$ 590$ \\
Comércio & $58 \$ 380$ & $41 \%$ & $142 \$ 390$ & $648 \$ 515$ & $94,8 \%$ & $683 \$ 695$ \\
P. Vida & $241 \$ 040$ & $15,5 \%$ & $1: 546 \$ 640$ & $1: 503 \$ 450$ & $56,7 \%$ & $2: 647 \$ 270$ \\
Dív. Ativa & $321 \$ 430$ & $34,7 \%$ & $924 \$ 600$ & $2: 473 \$ 396$ & $27,8 \%$ & $8: 880 \$ 189$ \\
Sertanismo & $80 \$ 740$ & $21,7 \%$ & $370 \$ 460$ & $372 \$ 160$ & $54,5 \%$ & $682 \$ 260$ \\
Monte-mor & $3: 107 \$ 740$ & $22,2 \%$ & $13: 973 \$ 900$ & $30: 272 \$ 896$ & $45,5 \%$ & $66: 391 \$ 609$ \\
Div. Passiva & $551 \$ 050$ & $31,9 \%$ & $1: 724 \$ 420$ & $8: 088 \$ 842$ & $75,8 \%$ & $10: 664 \$ 942$ \\
Monte- & $2: 556 \$ 690$ & $20,8 \%$ & $12: 249 \$ 480$ & $22: 184 \$ 054$ & $39,8 \%$ & $55: 726 \$ 667$ \\
menor & & & & & & \\
Inventários & 8 & $24,2 \%$ & 33 & 16 & $48,4 \%$ & 33 \\
\hline
\end{tabular}

Fonte: Idem.

Comparando-se os números referentes às décadas de 1680 e 1690, percebe-se claramente uma tendência de queda, tanto na riqueza da população em geral como do grupo sertanista. Esta situação tem suas causas assentadas no próprio contexto da colonização e na intensidade do envolvimento da vila neste processo.

A década de 1690 tem o seu diferencial porque foi o período das chamadas "descobertas oficiais" das minas de ouro. Devido somente a este fato, muitas mudanças ocorreram no panorama do Brasil, afetando de diversas maneiras as características da colonização, até então, tipicamente litorânea e sedentária, passando, a partir do final do século XVII, a apresentar ondas de migração, e a vila de Taubaté não podia ter ficado fora disso. Como já foi exposto anteriormente, o fluxo de homens que circulava entre o sertão e a vila começou a ser mais significativo após o início da década de 1680 e foi se acentuando drasticamente na década seguinte, situação notada pela respectiva queda no percentual de sertanistas, de 56,5\% (1670) para 41,1\% (1680), depois para 24,2\% (1690).

Juntamente com a massa populacional sertanista que migrou para as minas, foram parte de suas riquezas. É muito acentuada a diferença entre a parcela de riqueza correspondente ao grupo sertanista da década de 1680 para a de 1690 , isto é, este grupo era responsável por $55,6 \%$ da riqueza total da vila, passando depois para 22,2\%, uma forte queda que acompanhou a própria tendência no deslocamento das pessoas. Menor riqueza disponível é igual a menor comprometimento dela entre os setores da economia local. Enfim, o que se vê é uma realidade anormal, onde estruturas econômico-sociais bem 
assentadas durante anos sofreram modificações violentas devido ao chamado "rush" do ouro.

No entanto, os dados referentes à decada de 1700 mostram uma retomada dos padrões anteriores ao dito "rush". Não apenas a porcentagem da população sertanista volta a atingir aproximadamente a metade dos habitantes da vila, cerca de 48,4\%, como também concentra em suas mãos $45,5 \%$ da riqueza total da vila. Houve em quase todos os itens analisados uma expansão no controle exercido pelo grupo sertanista, com destaque para a posse de $75,4 \%$ do ouro existente na vila, também para os $94,8 \%$ do comércio, além dos tradicionais setores "rural" e "escravo", com 51,6\% e 46,4\%, respectivamente.

Apesar do aumento nos números reais das dívidas ativas, ocorreu uma queda na participação dos sertanistas neste setor, seguindo na contramão da tendência para o momento. Isso pode significar um maior envolvimento do restante da população no setor dos empréstimos, setor este cada vez mais visto como uma opção de atividade econômica altamente lucrativa. Se por um longo tempo os sertanistas se mantiveram como principal fonte de recursos disponíveis para empréstimos, os últimos anos do século XVII e, principalmente, o início do XVIII assistiram a inclusão de parte do restante da população, aqueles com capital à disposição, no circuito mercantil local, diminuindo assim a porção dominada pelos sertanistas nesta atividade.

Por fim, a década de 1710. Este período ficou marcado pela re-estabilização do poder econômico e social dos bandeirantes da vila, mas não re-assumiram a posição hegemônica que detinham décadas atrás. 
Tabela 24: Riqueza dos sertanistas em comparação a riqueza geral de Taubaté

\begin{tabular}{|c|c|c|c|}
\hline & \multicolumn{3}{|c|}{1710} \\
\hline Itens & Sertan & & Geral \\
\hline Rural & $5: 674 \$ 260$ & $71,4 \%$ & 7:939\$720 \\
\hline Urbano & $934 \$ 520$ & $38,2 \%$ & $2: 440 \$ 020$ \\
\hline Escravo & $25: 984 \$ 000$ & $57,3 \%$ & $45: 311 \$ 000$ \\
\hline Ouro & $10: 472 \$ 145$ & $36,6 \%$ & $28: 570 \$ 395$ \\
\hline Prata & $275 \$ 411$ & $43,3 \%$ & $633 \$ 651$ \\
\hline Comércio & $43 \$ 360$ & $8,4 \%$ & $5: 140 \$ 271$ \\
\hline P. Vida & $2: 490 \$ 010$ & $67,3 \%$ & 3:694\$530 \\
\hline Dív. Ativa & $9: 476 \$ 127$ & $41,6 \%$ & $22: 726 \$ 310$ \\
\hline Sertanismo & $180 \$ 440$ & $48,6 \%$ & $371 \$ 040$ \\
\hline Monte-mor & $55: 530 \$ 273$ & $47,5 \%$ & $116: 826 \$ 937$ \\
\hline Dív. Passiva & $14: 903 \$ 654$ & $76 \%$ & 19:602\$804 \\
\hline Monte-menor & $40: 626 \$ 619$ & $41,7 \%$ & $97: 224 \$ 133$ \\
\hline Inventários & 12 & $33,3 \%$ & 36 \\
\hline
\end{tabular}

Fonte: Idem.

Houve uma pequena queda na porcentagem da população envolvida com o sertanismo, de 48,4\% em 1700 cai para 33,3\% em 1710, mas isso não significou a diminuição do seu poder econômico, pois se manteve em torno de 47,5\%, algo bastante considerável.

Para esta última década, verifica-se que a riqueza do grupo sertanista estava depositada, em sua maioria, nos escravos, no ouro, nas dívidas ativas e passivas, e no setor rural. Este quadro expõe a divisão do poderio econômico dos sertanistas em dois pólos: parte representada pela produção rural-escravista, parte pelo setor mercantil através dos empréstimos. Ainda que o setor mercantil seja considerável, percebe-se que a preferência de seus interesses voltava-se cada vez mais para a ruralização dos recursos econômicos, visto que detinham $71,4 \%$ da riqueza equivalente ao item "rural" e 57,3\% do item "escravo", ou seja, mesmo que as atividades mercantis exercidas através do comércio e dos empréstimos tenham se mostrado bastante vantajosas naquele instante, já que a vila possuía amplo recurso financeiro oriunda do ouro extraído nas minas, o grupo sertanista procurou, aos poucos, assegurar o referido capital em setores tradicionais, talvez pela maior solidez do empreendimento, sem falar também na procura da promoção no quadro sócioestamental, ascensão esta materializada no desejo de "ser senhor". ${ }^{400}$ Para Maurício Martins

\footnotetext{
${ }^{400}$ Vale lembrar que, não obstante a presença da Casa de Fundição em Taubaté, a grande maioria dos negócios era feita com o ouro ainda em forma de pó, isto é, não quintado. Assim sendo, existem dois documentos elaborados por Arthur de Sá e Menezes alertando os oficiais da vila para os "descaminhos que há do ouro em pó", pois que "me tem chegado a notícia que [os mercadores]
} 
Alves, por exemplo, este processo de ruralização ocorreu por influência de aspectos que iam além da economia, isto é, "a troca de um setor altamente rentável (o controle da rede de adiantamento/endividamento) por outro menos rentável (o setor rural) aparece como uma paradoxo, e somente se justifica por fatores extra-econômicos." Salienta o autor que "o poder sobre as pessoas é mais importante que o controle econômico. Através do primeiro se mantém o segundo."401 De fato, não se pode excluir as condicionantes extra-econômicas, mas também não se deve minimizar as conjunturas e as forças que orientavam a economia naquele dado momente. A complexidade disso tudo está justamente na dificuldade de se mapear um ou outro fator isoladamente.

De maneira geral, observando todas estas tabelas, é possível pensar no grupo sertanista taubateano como um grupo que oscilou entre o maior e o menor poder econômico, cada momento com sua respectiva situação favorável ou não. Eram os sertanistas, ao contrário do que pensam alguns autores, pessoas comuns que dividiam seus afazerez cotidianos entre os assuntos referentes ao banderismo e a vida sedantária da vila e da fazenda, ocupando-se com a produção agrária, sem falar nas práticas comerciais e financeiras. Não eram apenas homens do sertão, eram também homens da vila, homens do comércio, do cultivo de alimentos, empreendedores e - por que não? - homens da casa. Pode-se afirmar, então, que os sertanistas de Taubaté eram um grupo que, como todo o restante da população, tinha suas bases econômicas assentadas naquilo que de mais seguro se podia obter numa realidade colonial: terras e escravos. Porém, se diferenciavam dos outros apenas pelo fato de utilizarem parte dos recursos financeiros e humanos nos empreendimentos que demandavam o sertão à procura de mão-de-obra, metais e pedras preciosas. Portanto, "não havia, em síntese, uma contradição entre a mobilidade do

buscam alguns subterfúgios para o sobre dito descaminho". Cita o dito governador que um deles seria a grande quantidade de transações comerciais por meio das dívidas. Nesse sentido, é lícito imaginar que o grupo bandeirante, possuidor de ampla quantidade de ouro em pó, e envolvido no negócio dos empréstimos possa ter procurado investidor tal montante "ilegal" em empreendimentos mais sólidos e seguros já que, caso fosse constatado a transgressão das leis, todo o ouro seria confiscado. Cf. "Ordem de Arthur de Sá e Menezes a Estevão Cavaleiro sobre os mercadores e sobre o ouro em pó, de 23 de setembro de 1701" e "Ordem de Arthur de Sá e Menezes ao Provedor da oficina de Taubaté sobre os mercadores, de 25 de setembro de 1701". In: Documentos Interessantes para a História e Costume de São Paulo. Publicação Oficial: Arquivo do Estado de São Paulo; São Paulo: Estabelecimento Gráfico Irmãos Ferraz, 1930. Vol. LI. p.37-41.

401 ALVES, Maurício Martins. Caminhos da Pobreza: a manutenção da diferença em Taubaté (1680-1729). Taubaté: Prefeitura Municipal de Taubaté, 1999. p. 93. 
bandeirante e o sedentarismo do colono. Ambas as tendências eram faces da mesma moeda, ambas expressavam o processo pelo qual a população paulista se adaptou às restrições geográficas, econômicas e demográficas que lhe foram colocadas pelo meio natural e pela dinâmica histórica colonial". 402

Pois bem, visto que os bandeirantes estavam inseridos numa mesma realidade e que compartilhavam com o restante da população as práticas coloniais de sobrevivência, falta verificar o posicionamento sócio-econômico que assumiram ao longo do tempo estudado.

É complexa a questão da origem social dos bandeirantes. A idéia geral encontrada na historiografia sobre o tema, consagrada na primeira metade do século XX, atribui a eles uma vida humilde e muito pobre, a qual foi inevitável a ida aos sertões para se "buscar o remédio". A imagem da pobreza generalizada existente na capitania de São Vicente forçou os estudiosos a entender a própria prática sertanista como uma resposta a difícil situação em que viviam seus habitantes. Dessa maneira, miseráveis eram os homens que se sujeitavam em ir ao sertão.

Nesse sentido, Oliveira Vianna atribui aos paulistas uma nobreza não de riqueza e sim guerreira. Para ele, “os homens de então, (século I e II) lançavam-se ao sertão para procurar 'remédio às suas necessidades', remédio obtido a golpes de lança e a tiros de bacamarte.” Essa seria uma condição imediata à pobreza difundida no cotidiano. Todavia, Vianna entende que "o valor dos homens era dado pela bravura." Diz ele que "estes rudes pobretões (como a moderna crítica quer que sejam os velhos bandeirantes) eram nobres porque bravos - e não porque ricos.” ${ }^{403}$ Suas palavras não mudam o tom de aceitação da idéia posta sobre a existência de vida sertanista em função de uma vida pobre; sendo assim o grupo social envolvido com as expedições fica tido como um grupo oriundo da pobreza, de uma camada sem recursos financeiros.

Já buscando expor uma diferenciação de níveis sócio-econômicos, Alcântara Machado ressalta duas formas de participação nas entradas sertanistas: uma através do invenstimento de capital feito somente pelos ricos, e a outra por meio da disponibilização do heroísmo, como responsabilidade dos pobres. ${ }^{404}$ Machado estava, em partes, correto.

\footnotetext{
${ }^{402}$ SANTOS, Márcio. Op. cit. p. 167-168.

403 VIANNA, Oliveira. Instituições Políticas Brasileiras. Vol. I. Fundamentos Sociais do Estado (Direito Público e Cultura). 2a . Edição. São Paulo: José Olympio, 1955. p. 170.

${ }^{404}$ Cf. MACHADO, Alcântara. Op. cit.
} 
Havia sim essas diferenças de participação, mas não eram as condições sociais as determinantes para tais divergências práticas. Logicamente que, enquanto uns possuíam mais recursos financeiros, outros pouco podiam disponibilizar além da própria força humana.

A bem da verdade, os sertanistas não estavam isolados numa faixa de nível sócioeconômica. Não formavam um bloco homogêneo em termos de condições financeiras, nem usufruíam dos mesmos padrões de vida, de conforto, de alimentação, de vestimenta, etc. É preciso definir melhor esta situação, por isso seguem adiante alguns gráficos que mostram a distribuição da população (sertanista e não sertanista) em diferentes faixas de riqueza. Acredita-se que esses dados permitirão a análise da desigualdade econômica, não só entre a população e os sertanistas, mas também entre o próprio grupo sertanista, isto é, um exame da desigualdade em vias horizontais e verticais.

Os gráficos elaborados para cada uma das décadas apresentam os seguintes dados: cada coluna representa uma faixa de riqueza e nelas estão divididos em porcentagem os inventários de sertanistas e não-sertanistas, ou seja, toda a documentação disponível sobre a sociedade taubateana. Através deste esquema obteve-se tais informações: 1) a baliza econômica - mínimo e máximo - da população medida por meio das faixas de riqueza; 2) a localização dos sertanistas nestes diferentes blocos; 3) a divisão da quantidade de inventários medida em porcentagem referente aos sertanistas e não-sertanistas distribuídas em cada faixa de riqueza. Estes três pontos permitem mostrar não apenas os níveis do poder aquisitivo alcançado por cada grupo social, mas também a amplitude do seu domínio. 


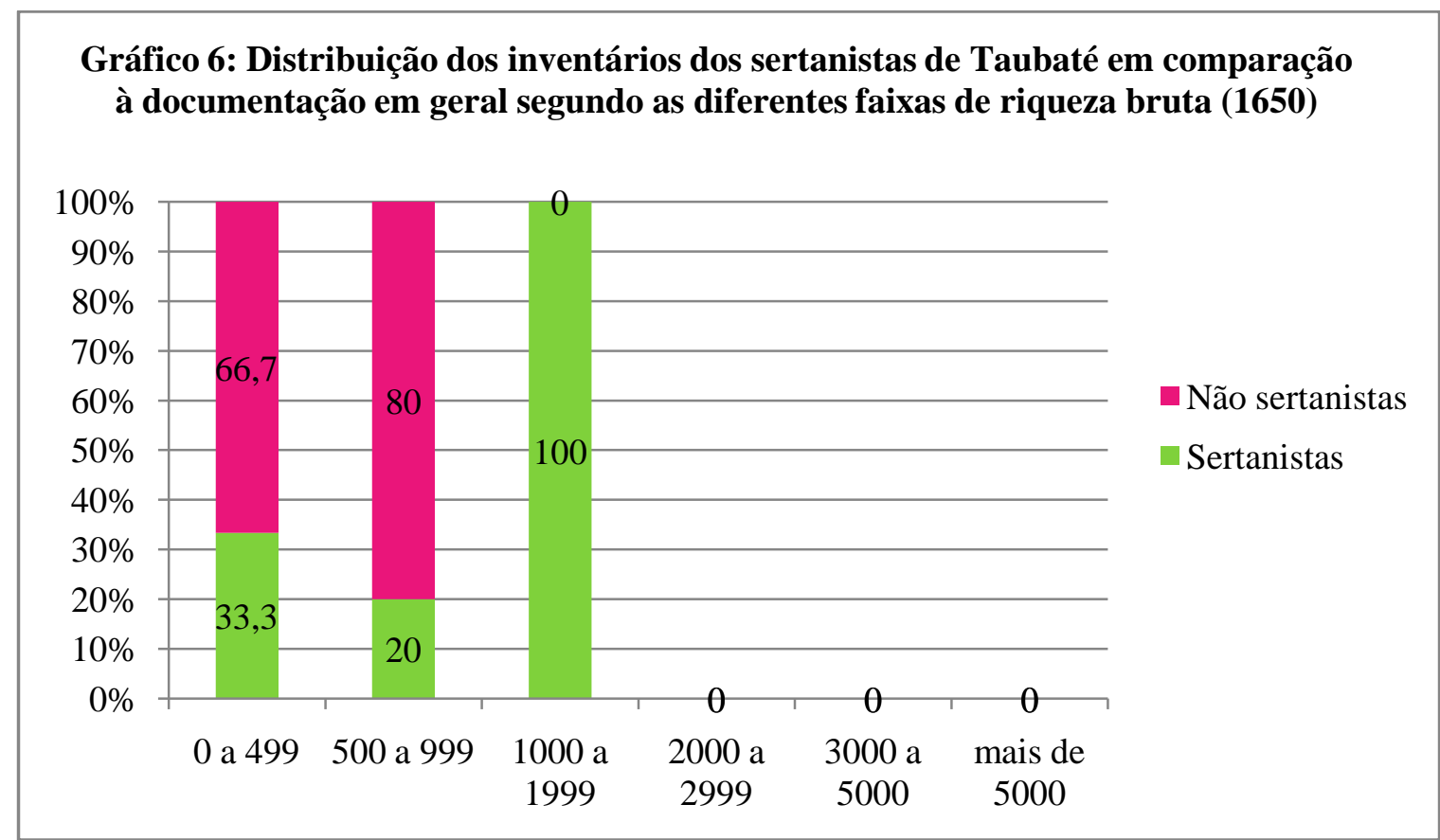

Fonte: Inventários (1649 a 1720). Arquivo Histórico Municipal de Taubaté.

Observa-se que, na década de 1650, o índice máximo de riqueza alcançado pela população chegou à faixa entre 1 conto de réis a 1:999\$000. Não se pretende aqui discorrer sobre os possíveis motivos e as situações em que se encontrava a vila de Taubaté nas diferentes conjunturas, mesmo porque isso já foi feito no capítulo anterior. Importa verificar apenas a distribuição dos sertanistas no quadro sócio-econômico local. Nesse sentido, nota-se que o grupo sertanista estava dividido entre os três blocos de riqueza definidos para a década, com destaque para o completo domínio exercido por tal grupo na faixa mais rica. 


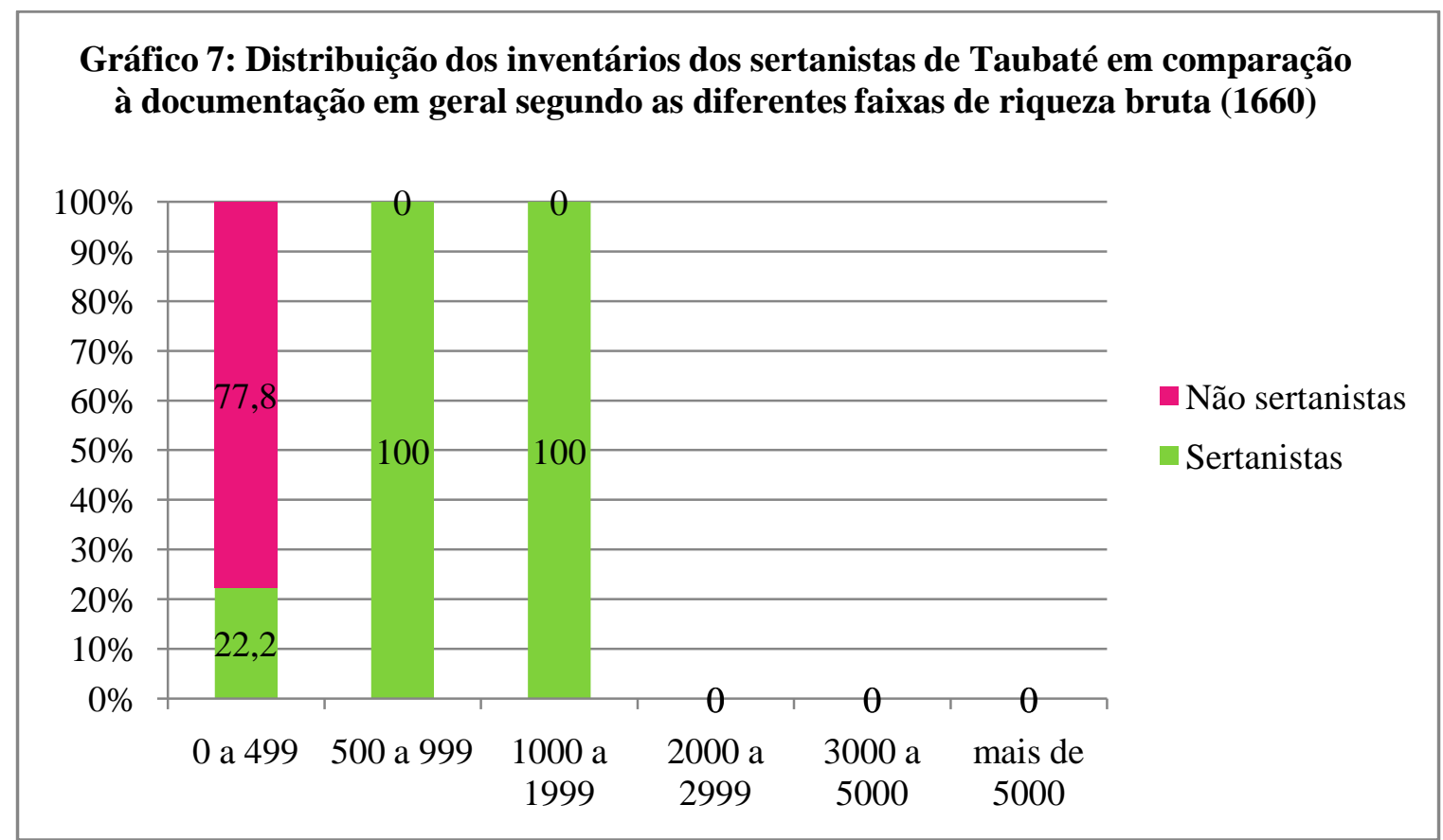

Fonte: Idem.

Também aqui, década de 1660, o alcance e a ocupação dos níveis de riqueza são muito parecidos com as do período anterior. Destaque para o aumento do domínio dos sertanistas que, agora, são unânimes nas duas faixas de maior poder aquisitivo.

No período seguinte, como se vê no gráfico abaixo, novamente a extensão máxima da riqueza dos indivíduos se mantém na terceira coluna, mas, agora, inexiste qualquer parcela da sociedade estacionada na faixa intermediária.

Em conjunto, as três primeiras décadas parecem muito uniformes. A riqueza individual dos habitantes de Taubaté atingiu o patamar mais elevado ao ficar entre 1 conto e 1:999\$000 réis. De igual maneira, os membros mais ricos foram, sem dúvida, aqueles que estavam envolvidos com as atividades sertanistas. 


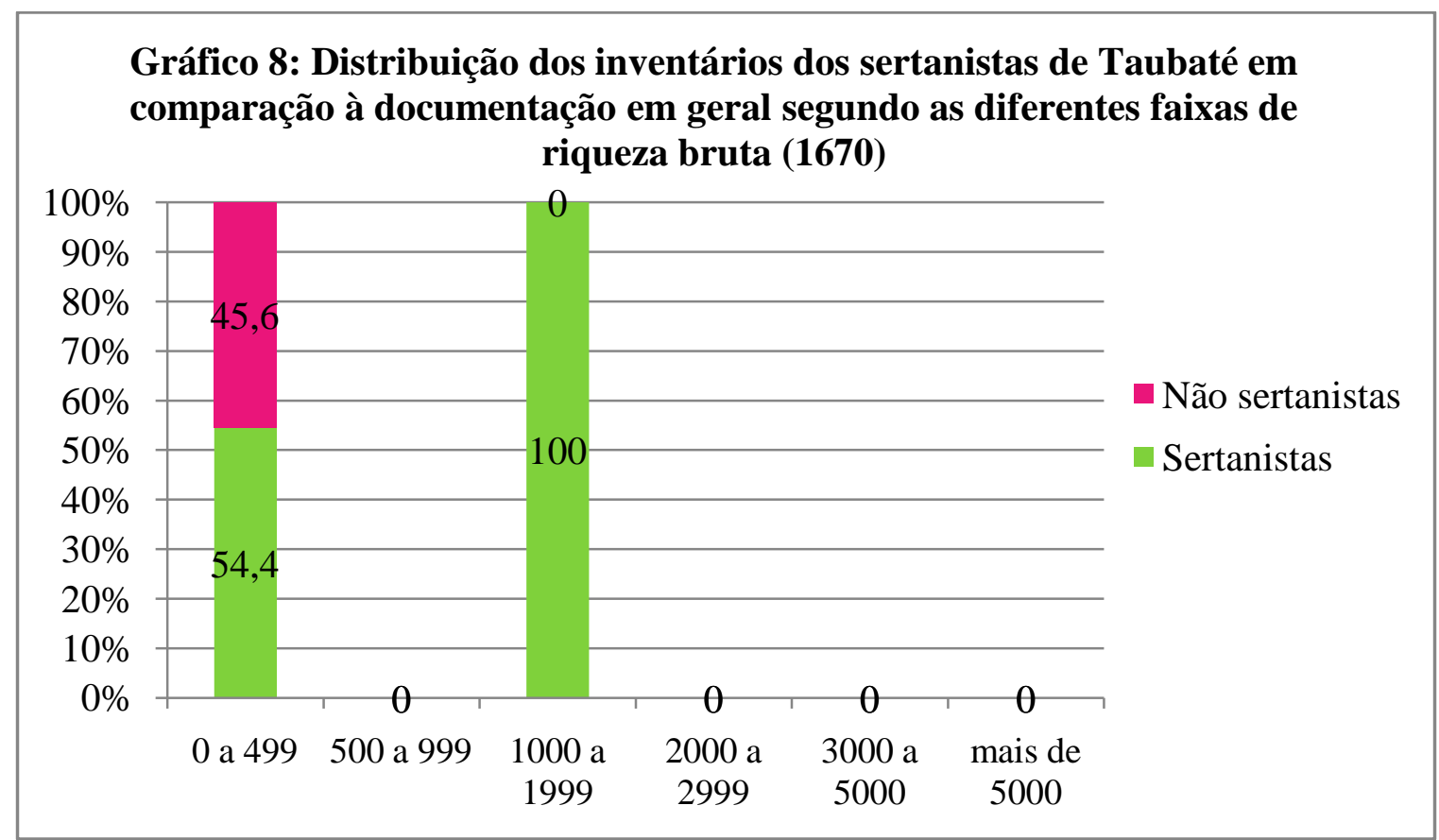

Fonte: Idem.

O panorama sócio-econômico local passou a sofrer mudanças somente com o início da década de 1680. Os mais ricos continuam sendo os sertanistas que, nesse instante, avançam nas faixas de riqueza, estacionando na quinta coluna (3 contos a 5:000\$000). Cresce, no entanto, a distribuição do grupo sertanista entre as faixas de menor poder aquisitivo. Vale lembrar que, o período entre 1670 e 1680, foi marcado pela manifestação das atividades bandeiristas em grande quantidade pelos habitantes da vila, o que justifica a maior participação de pessoas de diferentes níveis econômicos em tais empreendimentos. 


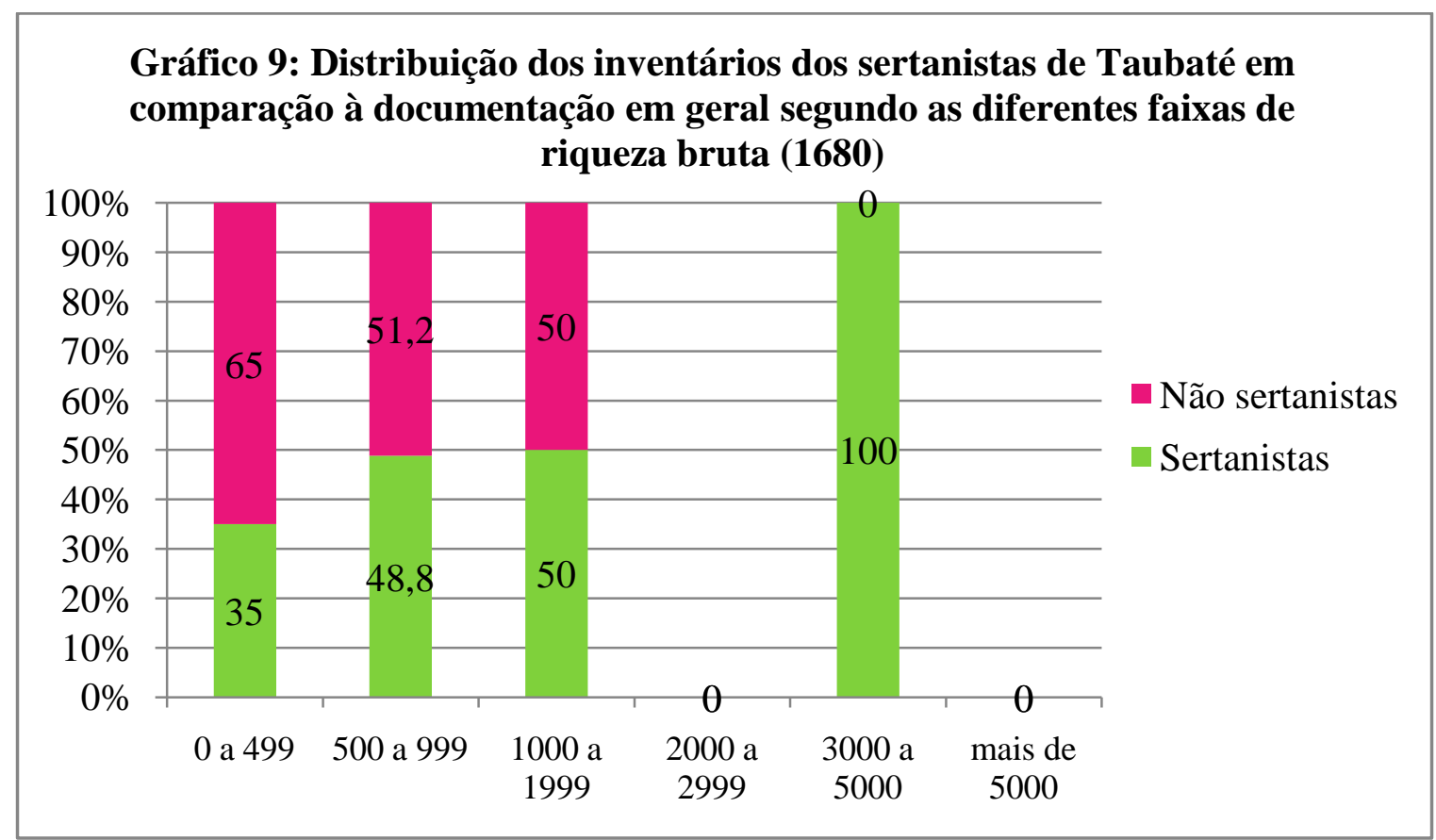

Fonte: Idem.

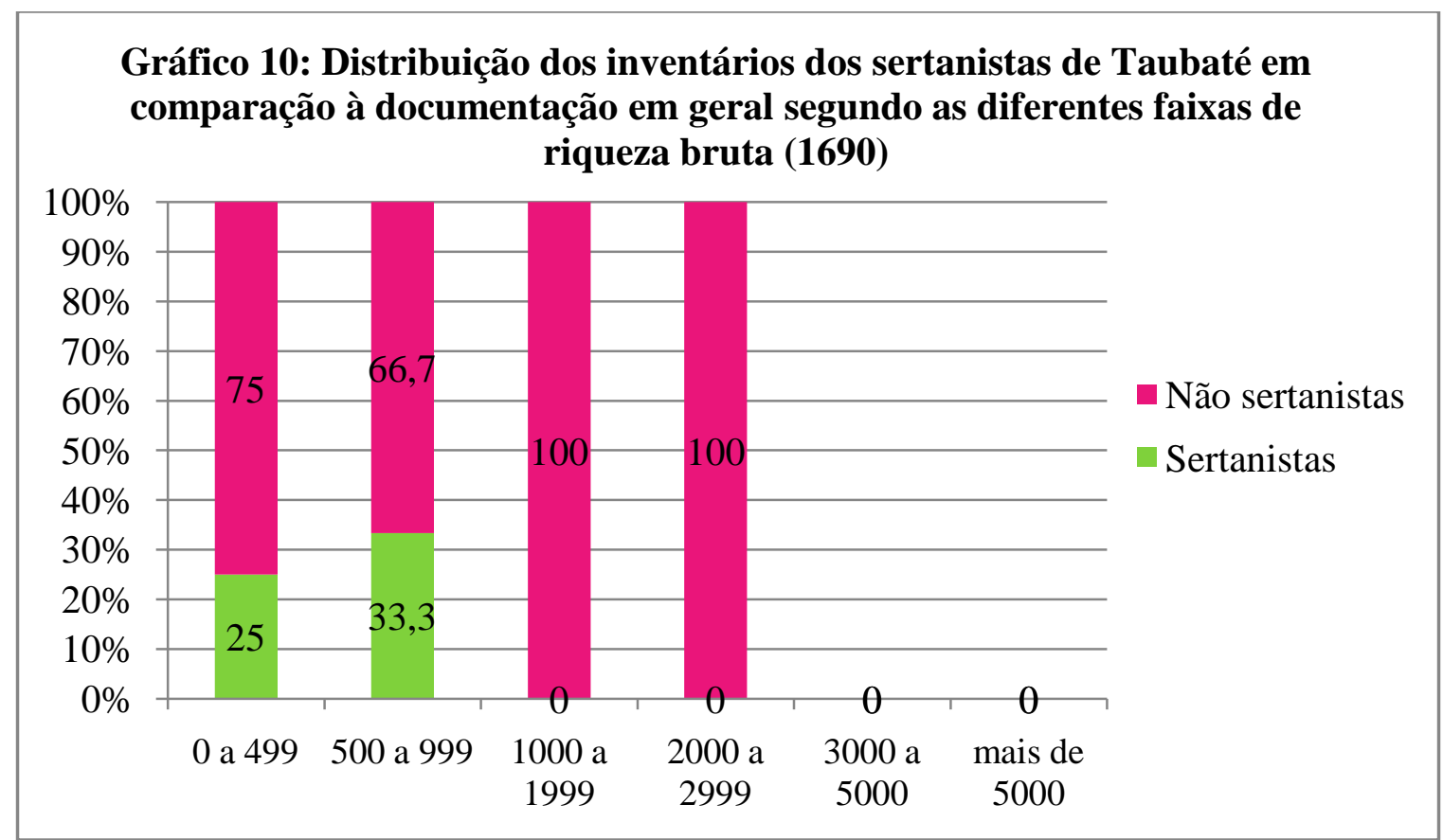

Fonte: Idem.

Como era de se esperar, a década de 1690 foi a que teve o maior grau de mudanças em função de tudo aquilo que ocorreu após as descobertas oficias da minas de ouro e que já foi analisado ao longo desta dissertação. 
A abertura de uma nova frente de oportunidades acarretou numa forte onda de migração que atingiu diversas partes do Brasil, inclusive Taubaté pois que muitos de seus habitantes tiveram participação ativa neste evento, talvez pela sua familiaridade com os assuntos sertanistas, máxime com a região mineira. $\mathrm{O}$ gráfico referente à última década do século XVII é bastante claro quanto a isso. Veja-se que a hegemonia econômica dos sertanistas desaparece, e o que resta destes se encontra nas camadas mais baixas. A saída da grande maioria do grupo bandeirante local possibilitou aos homens que não estavam envolvidos nas entradas sertanistas o domínio dos setores de maior poder econômico da vila. Mas essa situação durou muito pouco tempo, como se vê gráfico seguinte.

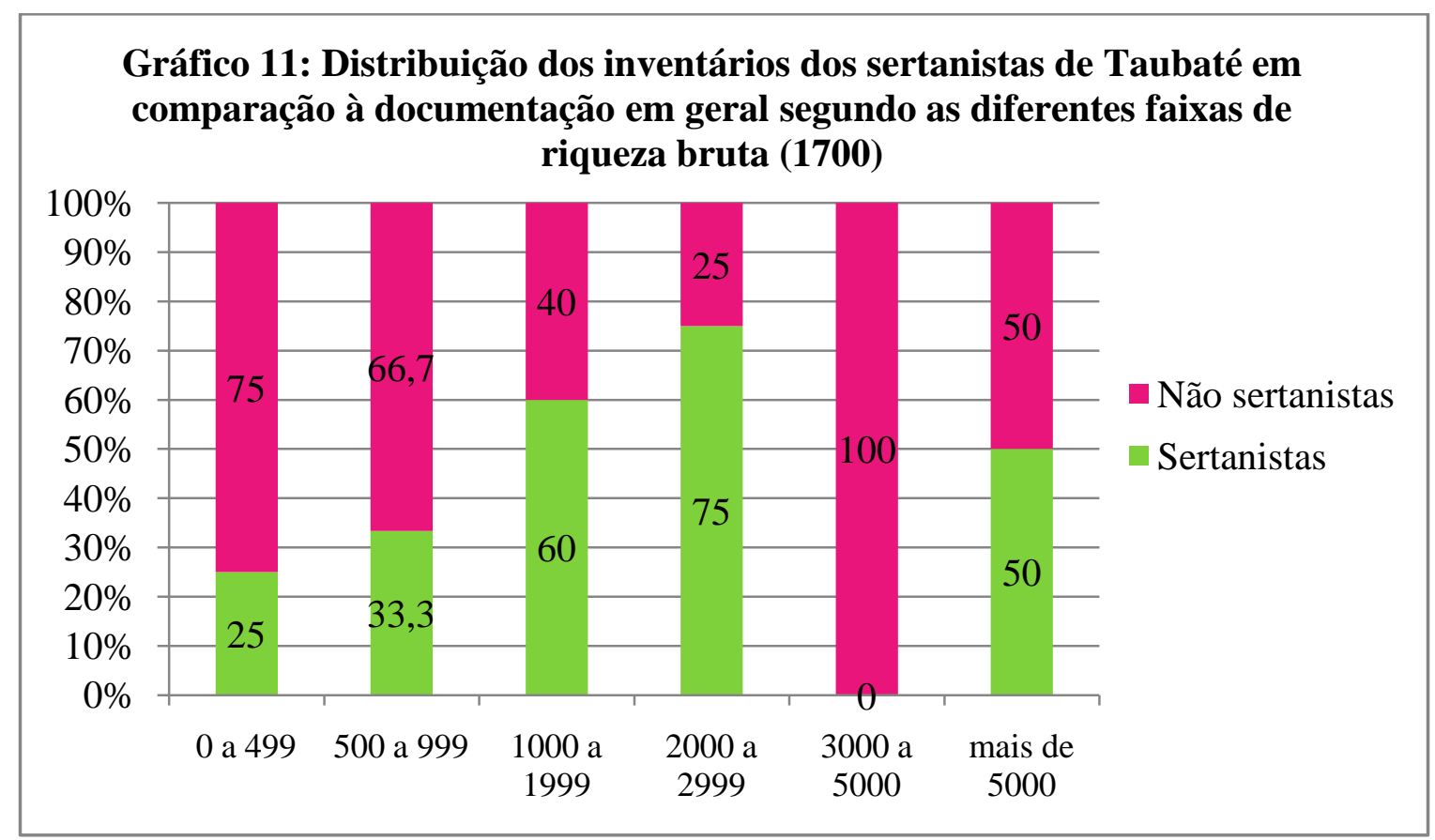

Fonte: Idem.

O primeiro fato a ser constatado é o enriquecimento individual da população e, consequentemente, da vila como um todo. Todas as faixas de riqueza foram atingidas. A injeção de ouro advindo das Minas Gerais foi o grande responsável por tudo isso, dando maior dinamização na economia local e disponibilizando recursos financeiros através da prática dos empréstimos, além da própria materialização de tais recursos na compra de escravos negros e na ampliação da produção agrária.

Se na década de 1690 muitos sertanistas deixaram Taubaté rumo às minas, muitos destes podem ter voltado na década seguinte, como sugere o gráfico. A retomada das posições sócio-econômicas está bem visível, porém não mais numa situação hegemônica, 
pois dividem o espaço com o restante da população dentro da cada faixa de riqueza, exceto na quinta. Mesmo assim, percebe-se que o grupo bandeirante volta com bastante força.

Enfim, a última década estudada mostra que além dos sertanistas voltarem com bastante força, estavam buscando retomar a antiga posição de domínio que exerceram por muito tempo. Ocupam, de fato, a maioria do espaço entre os homens mais ricos da vila, porém convivem ao lado de outros indivíduos que não estavam ligados ao seu grupo. Podese dizer que as oportunidades financeiras surgidas com o estabelecimento das Minas Gerais favoreceram não apenas aos homens tradicionalmente ligados ao movimento bandeirista, mas também muitos outros indivíduos que souberam aproveitá-las, elevando-se em meio a sociedade.

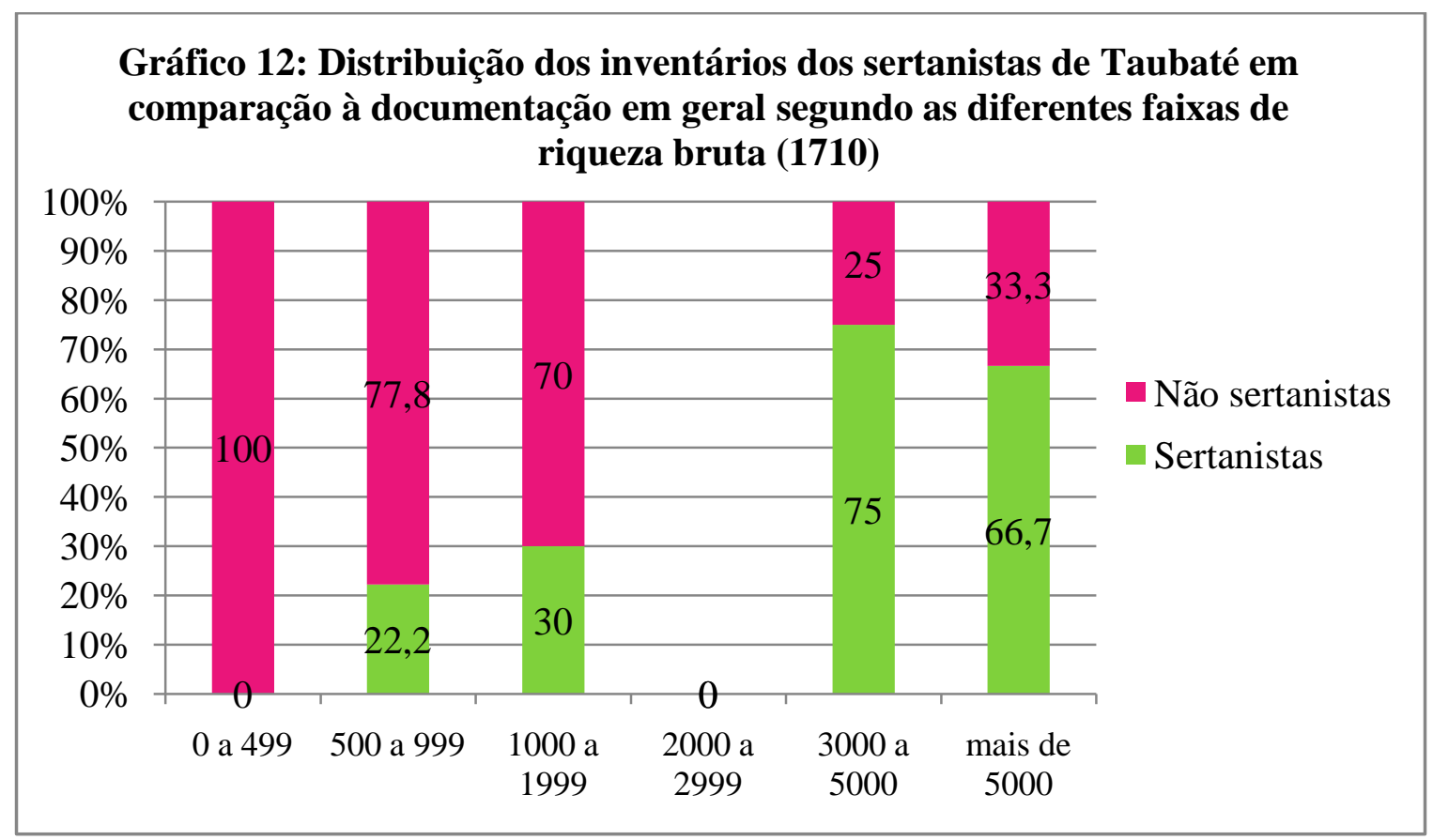

Fonte: Idem.

De maneira geral, a primeira impressão que se tem é a de que ao longo de todo o período considerado na pesquisa sempre houve uma heterogeneidade no poder aquisitivo da população taubateana, inclusive dos próprios sertanistas. Estes, como se nota, estavam distribuídos entre as faixas de riqueza, juntamente com suas variações momentâneas. Não é preciso voltar a discorrer sobre os motivos dessas variações que estavam intimamente 
ligados à trajetória econômica e social da vila. ${ }^{405}$ Importa apenas registrar a constatação da existência de uma realidade desigual e, através desta, verificar na sequência se havia por isso mesmo um condicionamento nas formas de participação nas bandeiras, como sugeriu Alcântara Machado.

Após a separação dos inventários dos sertanistas em faixas de riqueza, procurou-se identificar as formas com que atuavam nas expedições com intuito de mapear a existência ou não de práticas bandeiristas condizentes com o status sócio-econômico dos atores em questão.

Deu-se atenção primeiro aos mais ricos. O velho conhecido capitão Domingos Rodrigues do Prado, pai de outros também famosos sertanistas como seu filho homônimo, registrou em seu testamento, datado de 18 de março de 1715, que havia investido recursos financeiros em expedições das quais participaram alguns dos seus filhos. ${ }^{406}$ Logo, isto significa que o dito capitão apenas investiu e não participou diretamente de tais entradas. Tomando estas informações como referência e ainda o seu extenso poder aquisitivo, avaliado em 10:559\$710 réis, seria inevitável pensar nele apenas como um “disponibilizador” de capital. Todavia, fica difícil também não atribuir ao seu passado atuações em bandeiras, já que fazia parte de uma família tradicionalmente sertanista. A eventual participação em expedições fazia dele, então, um sertanista ativo e não somente um investidor ou espectador.

É o caso também do capitão Antonio Delgado de Escobar, falecido no ano de 1708. Em seu inventário está registrado o montante de 1:401\$080 réis como riqueza da família. Nada que se compare com aos 10:559\$710 réis pertencentes ao capitão citado no parágrafo anterior, mas era um patrimônio considerado confortável para a época. Apesar de ter declarado em testamento que mandou ao sertão um de seus filhos "com negros e aviamentos e gastos de minha casa da qual viagem trouxe cinco almas"407, ou seja,

\footnotetext{
405 Como já foi salientado no capítulo anterior, a evolução da produtividade, a maior dinamização da economia local, a injeção de riquezas após a descoberta do ouro nas Minas Gerais e as ondas de migração foram fundamentais para a variação nos níveis de riqueza familiar e, consequentemente, no panorama sócio-econômico da vila em geral.

406 Inventário do Capitão Domingos Rodrigues do Prado (1715). Cx: 1709-1715. A.H.M.T. O testamento encontra-se anexado ao inventário.

407 Inventário do Capitão Antonio Delgado de Escobar (1708). Cx: 1704-1717. A.H.M.T. O testamento encontra-se anexado ao inventário.
} 
contribuiu somente de forma financeira, tem-se notícia de que ele foi um dos primeiros sertanistas a descobrir ouro nas minas gerais. ${ }^{408}$

$\mathrm{Na}$ outra extremidade estavam os mais pobres. Existe sim um documento de um sertanista, Francisco Pedroso, que detinha baixo poder aquisitivo, cerca de $132 \$ 860$ réis, onde apresentou, pelo menos no momento da feitura do testamento, a preferência pela participação numa bandeira "para o sertão do Caeté" por meio do financiamento material, como pólvora e chumbo. ${ }^{409}$ Mas esse exemplo pode ser considerado uma exceção, uma vez que todos os outros sertanistas que dispunham de poucos recursos econômicos estavam sempre presentes fisicamente nas incursões ao sertão. Se lhes faltavam fundos para contribuir na organização e execução das bandeiras, o que lhes possibilitaria reservarem-se a própria ida nelas, restava-lhes apenas a disponibilização da própria mão-de-obra, isto é, era inevitável a integração pessoal nos trabalhos práticos do empreendimento sertanista.

Algumas considerações devem ser feitas a respeito do que foi encontrado na documentação taubateana a respeito dessas diferentes práticas relacionadas à posse de riquezas. Se por um lado os níveis de riqueza influenciavam na escolha da forma com que os sertanistas participavam das expedições, é preciso estender a análise para outros agravantes também bastante significativos.

Primeiro, está mais do que claro que as entradas sertanistas eram empreendimentos que visavam fins estritamente econômicos, seja na obtenção de mão-de-obra indígena, seja na extração de metais e pedras preciosas. Também ficou evidente a necessidade da aglutinação de esforços financeiros, materiais e humanos para a viabilidade na organização das expedições, o que determinou a prática generalizada da formação de associações de negócios entre os bandeirantes, cada um contribuindo como e com o que podiam. Nesse sentido, a maior ou a menor posse de riquezas condicionavam - não determinavam - a maneira como os indivíduos participavam nos ditos negócios. Costumeiramente, os mais pobres entravam com a própria mão-de-obra enquanto os mais ricos preferiam investir recursos. Esta lógica seguia tendências econômicas e não tinha como causalidade o eventual heroísmo ou a bravura dos homens.

${ }^{408}$ Cf. FRANCO, Francisco de Assis Carvalho. Dicionário de Bandeirantes e Sertanistas do Brasil. São Paulo: Comissão do V Centenário da Cidade de São Paulo, 1954. Verbete "Escobar, Antônio Delgado de".

409 Inventário de Francisco Pedroso (1687). Cx: 1678-1687. A.H.M.T. O testamento encontra-se anexado ao inventário. 
Como empreendimento econômico, as bandeiras eram atividades que despertavam interesse em parte da sociedade, visto os benefícios que por elas eram gerados. Ciente dos custos iniciais, muitos homens despossuídos de maiores recursos lançavam mão de empréstimos e da própria mão-de-obra como condição para a participação nas incursões, sempre de olhos nos lucros que delas viriam. Assim, estas atividades constituíam uma oportunidade de enriquecimento ou, pelo menos, de uma melhora no padrão de vida, tornando-se uma atração para muitas pessoas. No entanto, não eram todos os envolvidos nelas que alcançavam maior conforto financeiro, ao contrário, muitos ainda continuavam financeiramente dependentes de credores. Por isso, a constatação de que os mais pobres tinham por regra contribuir com a própria mão-de-obra para a execução das bandeiras, enquanto que os mais ricos apenas injetavam parte de seus recursos disponíveis.

Como segundo agravante, tem-se a processo de acumulação de capital. Similarmente ao o que ocorria em qualquer ramo existente na economia colonial, os investimentos feitos no sertanismo estavam sujeitos a um retorno positivo ou negativo. Mesmo que a expectativa dos lucros fosse alta, o lucro líquido parece não ser tão grande já que boa parte dos sertanistas precisou de muitos anos no ramo para obter uma situação financeira mais cômoda, outros nem isso conseguiam. A acumulação de capital, além de contar com a sorte nos empreendimentos e a melhor racionalidade nos negócios, era resultado do tempo, isto é, da prolongada participação ativa dos sertanistas nesse ramo. Idade e riqueza estavam intimamente relacionadas. Dessa forma, é lícito pensar numa mudança da prática dos sertanistas que se encontravam mais velhos e eventualmente mais ricos. Como ressaltado em exemplos anteriores, a preferência pelo investimento financeiro nas bandeiras e a não participação física como aspecto comum aos mais ricos pode ser o resultado do acúmulo da idade e de recursos disponíveis. Isso não significa que tal preferência se deu ao longo de toda a vida de um indivíduo, ao contrário, a persistência em muitas viagens ao sertão, os extensos gastos, os incalculáveis esforços efetuados durante muitos anos possibilitaram a alguns sertanistas o privilégio da opção, visto terem em mãos cabedal suficiente para o investimento. Definitivamente, não era o nível de bravura, muito menos o de heroísmo, os fatores que esclareciam as diferentes ações no movimento bandeirista. 
Interessante notar que a maioria dos sertanistas mais ricos encontrada na vila de Taubaté procurou investir em bandeiras das quais seus filhos faziam parte. ${ }^{410}$ Talvez isso fosse uma forma de minimizar os gastos e aumentar os lucros, além do que, servia também para iniciar e consolidá-los no ramo, ou seja, uma iniciativa de engajamento nos negócios da família, uma perpetuação das atividades econômicas.

Como foi conferido até aqui, o grupo sertanista não era homegêneo em se tratando de posse de riquezas. Havia alguns mais ricos e outros mais pobres. Situação bastante natural, não sendo nenhuma surpresa, portanto. A desigualdade existente entre os próprios sertanistas aguça a curiosidade em saber como estava este grupo em termos econômicos em relação ao restante da população, isto é, ao se tomar os sertanistas não como indivíduos isolados, mas em forma de grupo social, qual era o peso do conjunto de suas riquezas na economia local?

Talvez a avaliação da trajetória econômica seja um meio bastante válido para se encontrar evidências que denunciem os aspectos compensadores ou não dos empreendimentos sertanistas. Destacando-se o grupo sertanista da sociedade taubateana, foi possível traçar uma linha de comparação entre os níveis de riqueza, exposta no gráfico abaixo.

\footnotetext{
${ }^{410}$ O capitão Domingos Rodrigues do Prado, por exemplo, diz ter no sertão três dos seus filhos à sua custa. Já o capitão Domingos Gomes declarou estarem no sertão dois filhos seus por sua conta. Por fim, a capitão Manoel da Costa Cabral confessou em testamento ter mandado seu filho para as minas afim procurar ouro. Cf. Inventário do Capitão Domingos Rodrigues do Prado (1715). Cx: 1709-1715. Inventário do Capitão Domingos Gomes (1671). Cx: 1668-1677. Inventário do Capitão Manoel da Costa Cabral (1711). Cx: 1709-1715. A.H.M.T. Todos os testamentos encontram-se anexados aos seus respectivos inventários.
} 


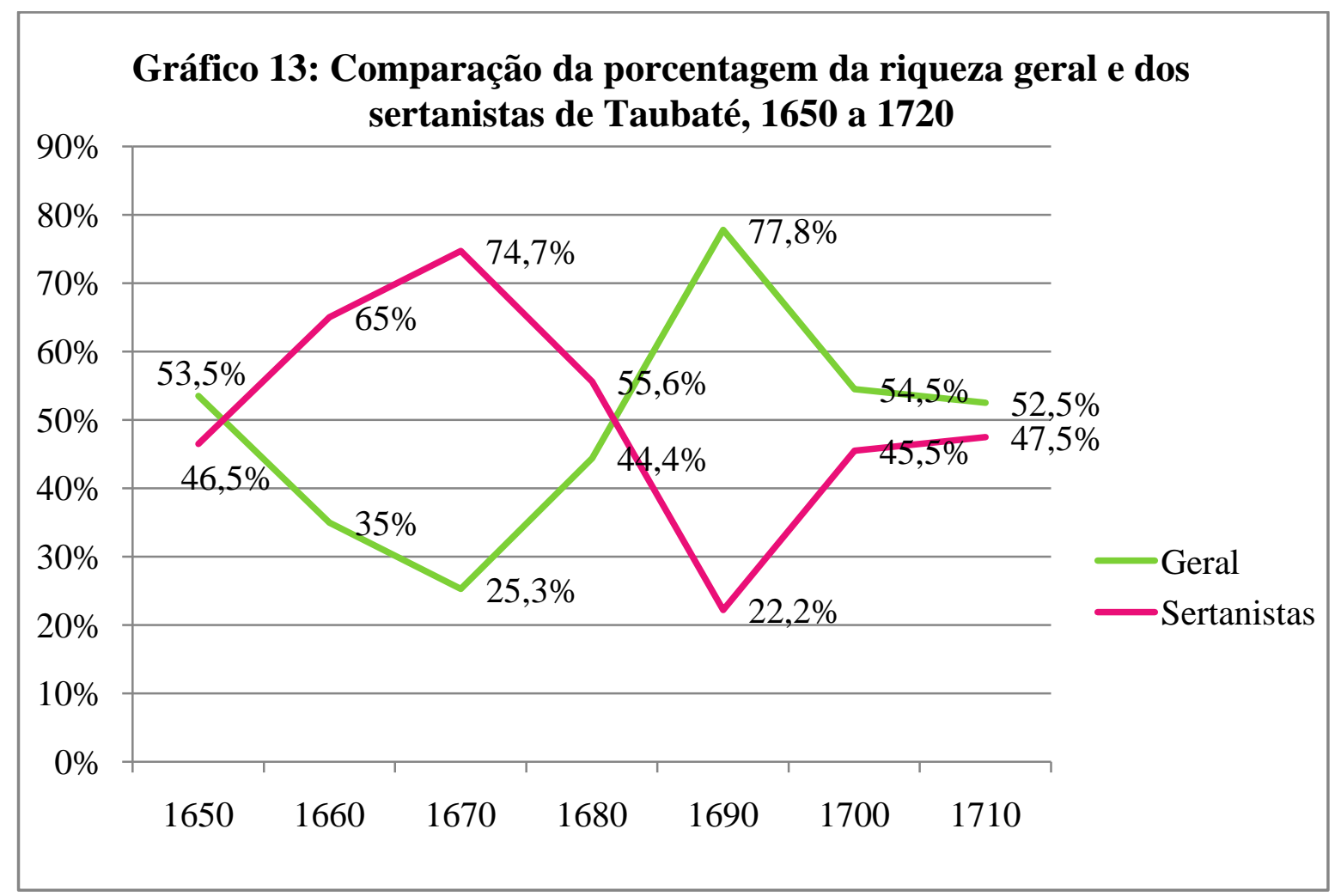

Fonte: Inventários (1649 a 1720). Arquivo Histórico Municipal de Taubaté.

As variações são claras e também discrepantes ao longo da segunda metade do século XVII, amenizando-se tais diferenças com o início do século seguinte muito em função da injeção de riqueza sob responsabilidade do ouro encontrado e de sua melhor distribuição. Tais ondulações estão intimamente relacionadas ao desenvolvimento produtivo e comercial da vila, e, principalmente, em relação ao constante fluxo migrátorio, aliás, esta movimentação de pessoas era muito comum no período colonial do Brasil sendo, portanto, bastante natural.

Basta cruzar as informações do gráfico acima com outro referente à porcentagem de população sertanista para melhor compreender seus resultados. ${ }^{411}$ Nas duas primeiras décadas, a de 1650 e 1660, a quantidade de pessoas envolvidas com o sertanismo ficou em cerca de $1 / 3$ da população representada pela documentação existente, sendo que a concentração de riqueza em suas mãos alcançava números cada vez mais significativos, indo de $46,5 \%$ para $65 \%$, respectivamente, ou seja, num dado momento, esses $1 / 3$ da sociedade controlavam aproximadamente $2 / 3$ da riqueza total da vila. Era, simplesmente,

${ }^{411}$ Conferir o gráfico 5 na página 127. 
uma forte canalização de recursos em um pequeno grupo social. Pode-se dizer até em uma elite econômica.

Nos anos seguintes, as atividades sertanistas prosperaram e atingiam mais e mais habitantes, aumentando para 56,5\% a porcentagem de pessoas atuantes nos negócios do sertão. Logicamente que, com essa tendência de crescimento, a posse de riqueza em mãos de bandeirantes também subia, chegando a 74,7\% para a década de 1670 . O próprio sucesso da vila nos empreendimentos sertanistas, situação notada pelo grande número de expedições e de negócios registrados nos inventários e testamentos desta década, pode ter levado ao declínio da quantidade de sertanistas e da concentração de riqueza como mostram os dados para a década de 1680. Queda da população sertanista, talvez em função do circuito de viagens e da abertura de novas fronteiras de exploração, e queda na taxa de riqueza como consequência da saída de bandeirantes da vila. Mas ainda assim tinham em suas mãos mais da metade de toda a riqueza da vila.

A inversão das posições aconteceu entre os anos de 1680 e 1690, voltando a população sertanista a ocupar o título de minoria $(24,2 \%)$ e, agora, a possuir apenas $22,2 \%$ dos recursos totais de Taubaté. A virada foi brusca a ponto de tal realidade permanecer durante os derradeiros anos do século XVII. Com a disseminação das notícias do achamento de minas de ouro, mesmo com o alvoroço causado entre toda a população, as primeiras pessoas a deixarem a vila em busca das oportunidades anunciadas foram aquelas já experimentadas nos negócios do sertão, por isso que os gráficos de população sertanista e de riqueza apontam para uma queda em seus dados para a década de 1690. A partir desse ponto de vista, não fica difícil de entender a virada nas posições sócio-econômicas da vila de Taubaté.

Contudo, as ondas de migração oriundas de muitas partes do Brasil, senão também de fora da colônia, atingiram principalmente as pessoas comuns, isto é, as que nada ou pouquíssimo conheciam do cotidiano dos sertões e das artimanhas frente ao perigo do desconhecido, mas que viram na ida para as lavras uma esperança de enriquecimento e de melhora nas condições de vida. O trânsito humano nunca tinha sido tão intenso até esse momento. Com o ínicio do século XVIII muitas mudanças ocorreram em Taubaté, tanto em termos econômicos, como sociais e demográficos. Seguindo a tendência migratória, parte da população da vila que nunca antes esteve envolvida diretamente nas atividades 
sertanistas também se deslocou para as minas, levando consigo não só as suas expectativas como uma porção de sua riqueza. Ao mesmo tempo em que isso ocorria, num caminho inverso os dados sobre a população sertanista apontam para uma retomada de crescimento, voltando com isso a conquistar a porcentagem de $48,4 \%$ do total da sociedade na década de 1700.

A ida de muitas pessoas para as minas, juntamente com o retorno de muitas outras eram duas faces da mesma moeda. Neste caso em específico, parecem ser os antigos sertanistas, pelo menos parte deles, os que retornaram à vila, uns com poucos outros com muitos frutos extraídos das minas. $\mathrm{Na}$ verdade, para além da obtenção de resultados materiais, alguns sertanistas puderam ver de perto a realidade dos povoados mineiros, suas carências e suas dificuldades diárias. Atentos a tudo, fizeram das suas experiências o ponto de partida para o incremento do sistema agrário produtivo de Taubaté com a injeção de mais recursos financeiros e materiais, como a compra de escravos africanos, por exemplo. O comércio de alimentos e de materiais com a região mineira passou a ser, então, a principal atividade econômica de muitos antigos bandeirantes.

As décadas de 1700 e 1710 apresentam uma retomada de crescimento da população sertanista e depois uma pequena queda até atingir a fração de 1/3 dela, aliás, esta fração é a mesma encontrada para a primeira década estudada, a de 1650. Em se tratando da posse de riquezas, o grupo sertanista voltou a concentrar grande proporção, de 22,2\% na década de 1690, deu um salto para 45,5\% em 1700 e 47,5\% em 1710. Concentração que traduz os frutos obtidos com as minas.

Todo esse quadro que denuncia certas tendências de mudanças demográficas e econômicas na vila de Taubaté esteve ligado diretamente às próprias condições locais de trabalho e de vida. Com especial destaque para as atividades sertanistas e o grupo social que as exerciam algumas reflexões devem ser feitas a partir das informações expostas acima.

A trajetória histórica do grupo sertanista residente na vila de Taubaté é bastante interessante. Com base nos dados obtidos através da análise de muitos inventários e testamentos pode-se dizer que, à exceção da década de 1690, eles formavam uma elite econômica local. Para as outras seis décadas estudadas suas posses ficaram entre um mínimo de $44,4 \%$ e um máximo de $74,7 \%$ do total da riqueza, o que permite situá-los numa 
posição bastante confortável entre a população em geral. Logicamente que entre eles mesmos havia aqueles mais pobres e outros mais ricos, mas analisando-os como grupo social, eram donos de um poderio financeiro, capaz inclusive de catalisar muitas das atividades econômicas da vila, tais como os investimentos no setor rural, nos escravos e, em especial, na disponibilização de recursos pela via de empréstimos.

De fato, os esforços em prol do desenvolvimento sertanista obtiveram sucesso. Por muitas décadas, seus agentes controlaram as principais fontes de riqueza, ditando com isso as desigualdades presentes no cerne da sociedade. Vale lembrar que tal sucesso abarcou não apenas o apresamento de grande leva de índios que foram destinados ao comércio e prioritariamente à produção local, mas também nas pesquisas metalíferas que acabaram por contribuir no desenvolvimento da exploração sistemática do ouro a partir da década de 1690. Todavia a questão que se levanta é: todo esse esforço de cunho financeiro, material e humano foi compensado através dos seus resultados?

Bem, não se pode negligenciar a posição confortável em que viviam alguns dos sertanistas ao longo do período estudado. Porém, o que se questiona aqui é se as variações no grau de posse de riquezas foram vantajosas ou não, já que o que predominou no tempo foi a sua queda. Em outras palavras, como um grupo social que dominou em termos econômicos a vila de Taubaté, em décadas iniciais, ao atingir a concentração máxima de $74,7 \%$ da riqueza total se comportou para manter o status de elite local mesmo com a queda no seu acúmulo de riqueza uma vez que, após a abertura das frentes de exploração metalíferas, outros setores sociais não ligados ao sertanismo também puderam aumentar suas posses, fazendo, assim, concorrência ao poder dos antigos bandeirantes?

No gráfico acima, que expõe as linhas de variação na porcentagem de riqueza dos sertanistas e do restante da população, fica evidente as mudanças que ocorreram após as descobertas do ouro. Juntamente com a evolução econômica da vila, com o crescimento de sua dinâmica produtiva e financeira, parece ter havido também a queda na concentração da riqueza assegurada em poucas mãos, isto é, a injeção de recursos oriundos das novas oportunidades de negócio que surgiram nos anos finais do século XVII possibilitou um enriquecimento da vila, enriquecimento este que atingiu áreas sociais até então não envolvidas com o tradicional sertanismo, levando a um equilíbrio no poderio econômico entre os bandeirantes e não-bandeirantes. Isso não quer dizer que o grupo sertanista se viu 
privado dos seus privilégios econômicos, ao contrário, continuaram com um alto padrão de vida $^{412}$, porém agora não estavam mais a sós na gerência do mercado financeiro interno, tinham concorrentes que de igual maneira possuíam recursos suficientes para colocar em circulação na dinâmica local.

Portanto, a partir de uma análise estritamente econômica viu-se que os esforços em prol do movimento bandeirista serviram para manter em funcionamento a estrutura produtiva e comercial da vila de Taubaté, principalmente porque geravam as sucessivas insersões de mão-de-obra indígena e, posteriomente, de ouro. $\mathrm{O}$ sucesso desse empreendimento também serviu para solidificar a posição social de seus agentes no comando financeiro local, considerado aqui como uma elite econômica. No entanto, com a virada do século e com a exploração das minas de ouro, essa posição privilegiada esteve ameaçada por outros setores da sociedade até então não envolvidos com o círculo sertanista. A equiparação dos poderes econômicos é evidente. Enfim, pode-se dizer que se por um lado o grupo sertanista obteve sucesso durante todo o tempo estudado, uma vez que viabilizou a consolidação e manutenção de seu poder econômico, por outro lado o próprio sucesso nas entradas sertanistas, responsável pela escravização dos índios e pelo encontro de metais e pedras preciosas, também ofereceu para o restante da sociedade não só os elementos humanos necessários para o funcionamento do sistema produtivo como também

${ }^{412}$ Ao mencionar padrões de vida considera-se, aqui, o contexto espaço-temporal da pesquisa. Logicamente que é preciso relativizar a riqueza existente nas tantas realidades que compõem o mundo colonial, máxime no Brasil. Não há dúvida de que o nordeste açucareiro, como principal centro dinâmico da exploração colonial, apresentava níveis de riqueza muito superiores aos de São Paulo e, principalmente, aos de Taubaté. Todavia, "se é certo que os níveis de riqueza verificados em São Paulo através dos testamentos e inventários dos séculos XVII e XVIII destoam daquilo que se conhece acerca dos senhores de engenho nordestinos, nada contudo permite dizer que a massa de lavradores paulistas vivesse em condições piores que a de seus congêneres em outras capitanias." SILVA, Maria Beatriz Nizza da (org.). História de São Paulo Colonial. São Paulo: Editora UNESP, 2009. p.103. Como exemplo do alto nível financeiro de que usufruíam uma parcela do grupo sertanista, selecionou-se apenas um de seus membros, Manoel Dias Ferreira, inventariado no ano de 1713. Sua fortuna foi avaliada em 12:251\$030 réis. A fim de comparar tal riqueza pertencente a um bandeirante, somou-se todo o montante da riqueza dos indivíduos inventariados na mesma década (1710) que não estavam ligados ao sertanismo. Com a soma de 24 montantes diferentes, chegou-se ao valor de 56:597\$514 réis, portanto, somente a riqueza de Manoel correspondia a nada menos do que $21,6 \%$ deste valor, ou seja, em termos individuais Manoel e outros sertanistas que também concentravam extensa riqueza tinham à sua disposição um alto padrão de vida, guardada as circunstâncias materiais, é claro. Cf. Inventário de Manoel Dias Ferreira (1713). Cx: 1704-1717. A.H.M.T. 
a riqueza materializada na forma da exploração do ouro em si e na constituição de novos mercados consumidores, assim abrindo caminho para o enriquecimento de outros setores da sociedade. As ações de um grupo igualavam-se a uma faca de dois gumes ao beneficiar direta e indiretamente outras partes da sociedade.

Já que no âmbito econômico os sertanistas não foram beneficiados o suficiente, pelo menos não o foram exclusivamente, pois tiveram que dividir o poder com outros indivíduos, outros elementos também compunham os critérios de elevação de status, como o exercício de cargos públicos e a posse de patentes militares. Tão importante quanto a riqueza, estes elementos faziam parte da cultura colonial e eram vistos como símbolos de enobrecimento, por isso serão analisados daqui em diante.

\subsection{Poder Político e Militar dos Sertanistas}

A formação de uma elite local levava em conta não apenas a extensão da posse econômica de seus membros, mas também a exposição pública de seu poder através da obtenção de símbolos de distinção que a revestia com um manto de reconhecimento social, permitindo-lhe, dessa maneira, exercer um controle sobre a população.

O domínio econômico atribuído aos sertanistas da vila de Taubaté, domínio este que se manteve por muitos anos até sofrer uma queda devido à maior distribuição da riqueza ocorrida em fins do século XVII e início do XVIII, pode ser considerado o primeiro passo para a conquista de outras formas de destaque social. O caminho mais prático para a elevação do status era, portanto, “(...) por meio do controle das instituições locais, como as câmaras ou mesmo as ordenanças," sendo através deste que "as elites procuravam ter acesso a honras, privilégios e signos de distinção." ${ }^{413}$ Nesse sentido, é de vital importância conferir a participação dos sertanistas locais nestes órgãos.

Como exposto no capítulo anterior, verificou-se que $17,3 \%$ da população masculina ocupou o cargo de juiz ordinário e/ou dos órfãos. Apesar de não se ter os dados referentes aos outros cargos existentes na câmara municipal, principalmente o de vereador, a própria constatação do caráter excludente do acesso aos cargos públicos que vigorava de forma

${ }^{413}$ BICALHO, Maria Fernanda Baptista. "As câmaras ultramarinas e o governo de Império". In: FRAGOSO, João; BICALHO, Maria Fernanda Baptista; GOUVÊA, Maria de Fátima Silva. (Orgs.) O Antigo Regime nos Trópicos: a dinâmica imperial portuguesa (séculos XVI-XVIII). Rio de Janeiro: Civilização Brasileira, 2001. p. 207. 
generalizada no Brasil colonial, para não dizer no Império português como um todo, permite dizer que somente um pequeno grupo de pessoas transitava no círcuito político. Mesmo porque "desde o século XVII, quase todas as intervenções da Coroa, bem como a atuação dos seus magistrados, encaminhara-se no sentido de garantir que os ofícios nas vereações e os cargos nas Ordenanças fossem ocupados pelos 'principais' das terras." ${ }^{414}$ Assim, identificar o grupo social que controlava o exercício do cargo de juiz ordinário e dos órfãos significa atribuir a ele também a posse dos outros cargos camarários, o que colocava, de fato, em suas mãos os meios concretos do mando político local.

Para tanto, elaborou-se um gráfico que demonstra claramente a divisão entre sertanistas e não sertanistas no exercício político da vila.

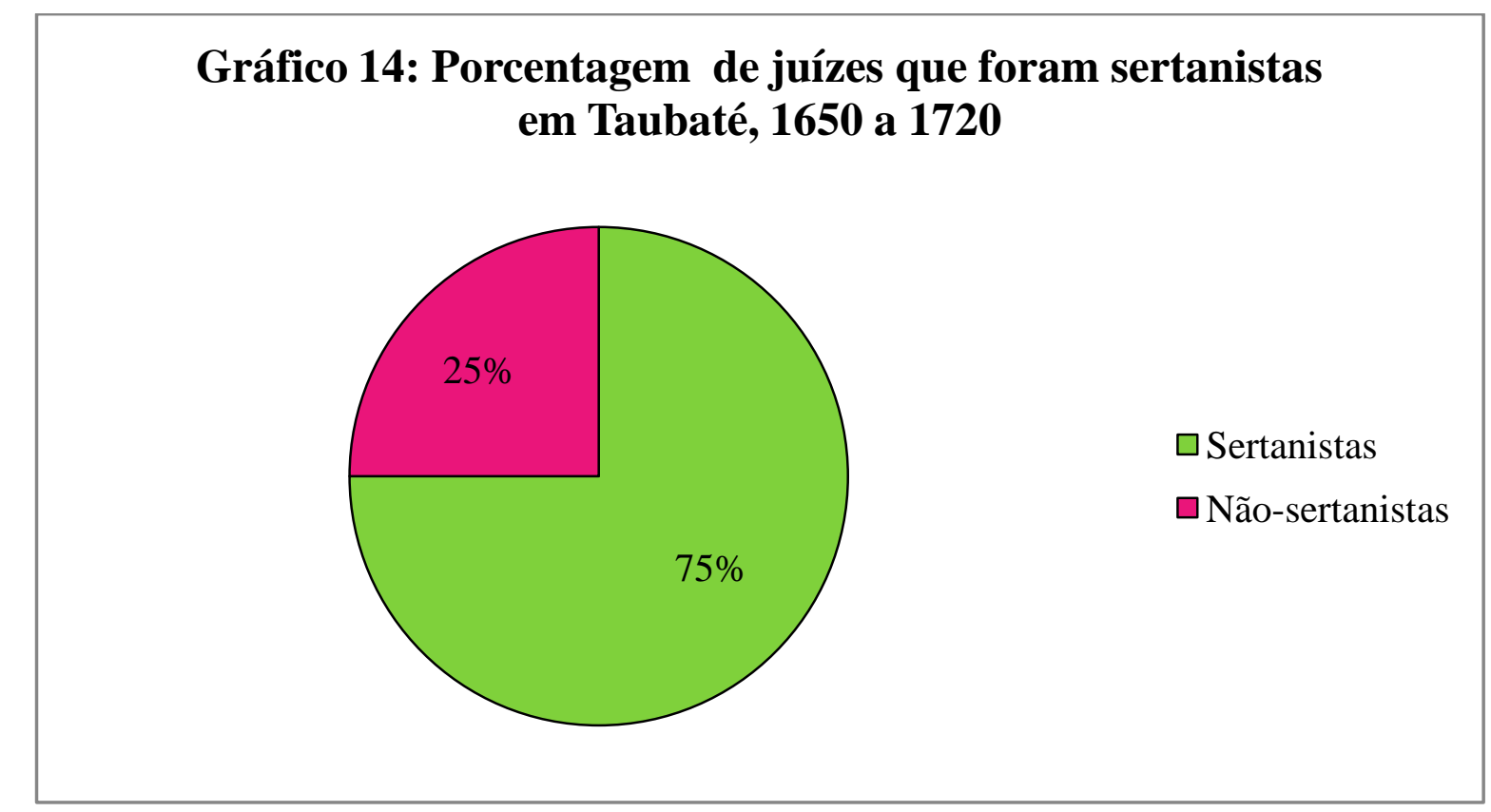

Fonte: Inventários (1649 a 1720). Arquivo Histórico Municipal de Taubaté.

O predomínio dos sertanistas no círculo do mando local é evidente, visto que formavam nada menos do que $3 / 4$ do contingente administrativo. A composição sóciopolítica de Taubaté era, assim, dominada por aqueles que tinham no bandeirismo um importante ramo de suas atividades econômicas.

${ }^{414}$ BICALHO, Maria Fernanda Baptista. "As câmaras municipais no Império português: o exemplo do Rio de Janeiro." In: Revista Brasileira de História. São Paulo: Anpuh/Humanitas. Vol. 18, nº 36, 1998. p. 263. 
Para alguns autores apenas o envolvimento nas expedições sertanistas bastava para os indivíduos serem qualificados para os cargos da governança. Waldomiro Benedito de Abreu, por exemplo, acredita que "na capitania de S. Vicente, nos dois primeiros séculos, formavam a nobreza natural rural os bandeirantes e povoadores e seus descendentes, os quais constituíam a classe dirigente, mesmo superior aos reinóis." ${ }^{415}$ Nas entrelinhas, Abreu parece atribuir a hegemonia política dos bandeirantes à sua condição de nobreza, condição esta adquirida através da bravura, do heroísmo e do pioneirismo intrínseco ao movimento sertanista. $^{416}$ Estas qualificações tinham o seu alto grau de consideração devido, segundo ele, a uma pernamência no Brasil de práticas e costumes medievais. ${ }^{417}$

Também nesta linha de raciocínio, os irmãos Ferreira ratificam a idéia de uma nobreza bandeirante. Dizem que, “em São Paulo, essa nobreza era constituída principalmente dos bandeirantes e seus descendentes. Dos grandes chefes bandeirantes, bem entendido, e não de todos os participantes das bandeiras." ${ }^{418} \mathrm{Na}$ verdade, a afirmação da existência de uma elite bandeirante não deixa de estar correta, principalmente quando se defende uma hierquização social dentro do próprio grupo. Todavia, entende-se que o equívoco presente nas idéias dos Ferreira fica por conta da relação entre as práticas sertanistas e a condição social de nobreza de algumas pessoas. Para esses autores, somente as bandeiras poderiam manter o status de nobreza de uma parte da sociedade e, ao mesmo tempo, somente os nobres estariam aptos a colocar em ação os planos sertanistas. Tudo isso porque "lutando para que tanto eles, como seus filhos, não descessem à condição de oficiais mecânicos, os nobres procuravam no sertão, os índios que iriam trabalhar nas suas fazendas, e os minerais preciosos que lhes proporcionariam o cabedal necessário para continuarem a viver à lei da nobreza." Dessa maneira, "se não existisse essa condição de

415 ABREU, Waldomiro Benedito de. Pindamonhangaba: tempo e face. Aparecida: Editora Santuário, 1977. p. 268.

${ }^{416}$ Chegou-se a essa conclusão devido ao tom de exaltação existente nas falas do autor que percorre todo o livro, principalmente quando se refere aos antigos bandeirantes e, é claro, devido a sua defesa da permanência dos valores medievais, observados por ele, nas características dos paulistas.

417 Para ele "enquanto nas povoações e vilas (Taubaté da época) se criava, aos poucos, uma burguesia (ofícios diversos a que os nobres não podiam ou não deviam dedicar-se), nos sertões, nas roças, nas propriedades agrárias, persistia sempre uma forma de vida retardada, da Idade-Média." Assim, "o curioso é que tal sociedade medieval tenha sobrevivido até dias bem próximos de nós, não podendo considerar de todo extinta, apesar de completamente anacrônica." Idem, Ibidem. p. 269.

${ }^{418}$ FERREIRA, Tito Lívio; FERREIRA, Manoel Rodrigues. História da Civilização Brasileira. São Paulo: Ed. Gráfica Biblos, 1959. p. 233. 
nobre, com toda a certeza não teriam existido as bandeiras". Concluindo, enfim, que "o bandeirismo foi uma exigência da própria condição de nobreza dos que escreveram essa epopéia." ${ }^{419}$ Ora, onde estavam as influências econômicas? A demanda por mão-de-obra? A crescente dinâmica comercial? O enriquecimento das pessoas?

Bem, como foi visto ao longo de todas estas páginas, o grupo sertanista que atuava na vila de Taubaté esteve à frente do restante da população em termos econômicos, atingindo um patamar de elite local, com suas variações no tempo, evidentemente. Nesse sentido, acredita-se que o desenvolvimento produtivo e comercial juntamente com o enriquecimento da população, máxime do grupo sertanista, era ao mesmo tempo a mola propulsora do movimento bandeirista e o resultado dele. Formavam um círculo vicioso onde o crescimento econômico gerava maiores demandas por mão-de-obra e, através desta, aumentavam a produtividade que, por fim, acabava por injetar mais energia na dinâmica comercial da vila. Em tal contexto, o grupo sertanista se destacou economicamente por acumular em suas mãos não apenas o monopólio da inserção de trabalhadores forçados mas também outras fontes de recursos como a produção agrária e $\mathrm{o}$ adiantamento/endividamento.

A procura por ofícios governamentais por parte dos sertanistas não deve ser vista apenas como uma consequência de um hipotético status de "nobreza". É preciso relacionar o exercício de funções políticas com as intenções de expansão do controle social e da manutenção das condições favoráveis a um determinado grupo em ascensão, neste caso, o bandeirante.

O próprio caráter excludente do processo seletivo a que estavam sujeitos os pretendentes aos cargos camarários exprimia muito bem a formatação das tendências políticas locais que, como de costume, estavam em consonância com os interesses particulares de uma parte da população, isto é, “(...) não apenas as principais famílias da vila, cidade ou região eram representadas na câmara, mas ainda que a câmara advogava, articulava e protegia os interesses das elites locais."420

\footnotetext{
${ }^{419}$ Idem, Ibidem. p. 344-345.

${ }^{420}$ RUSSEL-WOOD, A. J. R. "Centros e Periferias no Mundo Luso-Brasileiro, 1500-1808”. IN: Revista Brasileira de História. São Paulo, ANPUH/Humanitas Publicações, Vol. 18, nº 36, 1998. p. 208.
} 
No que diz respeito a Taubaté, o grupo sertanista dominou os rumos tomados pelo governo local durante muito tempo, sendo que, em alguns momentos específicos, esta hegemonia se viu ameaçada. $\mathrm{O}$ gráfico abaixo exprime tais forças de influência no mando da vila.

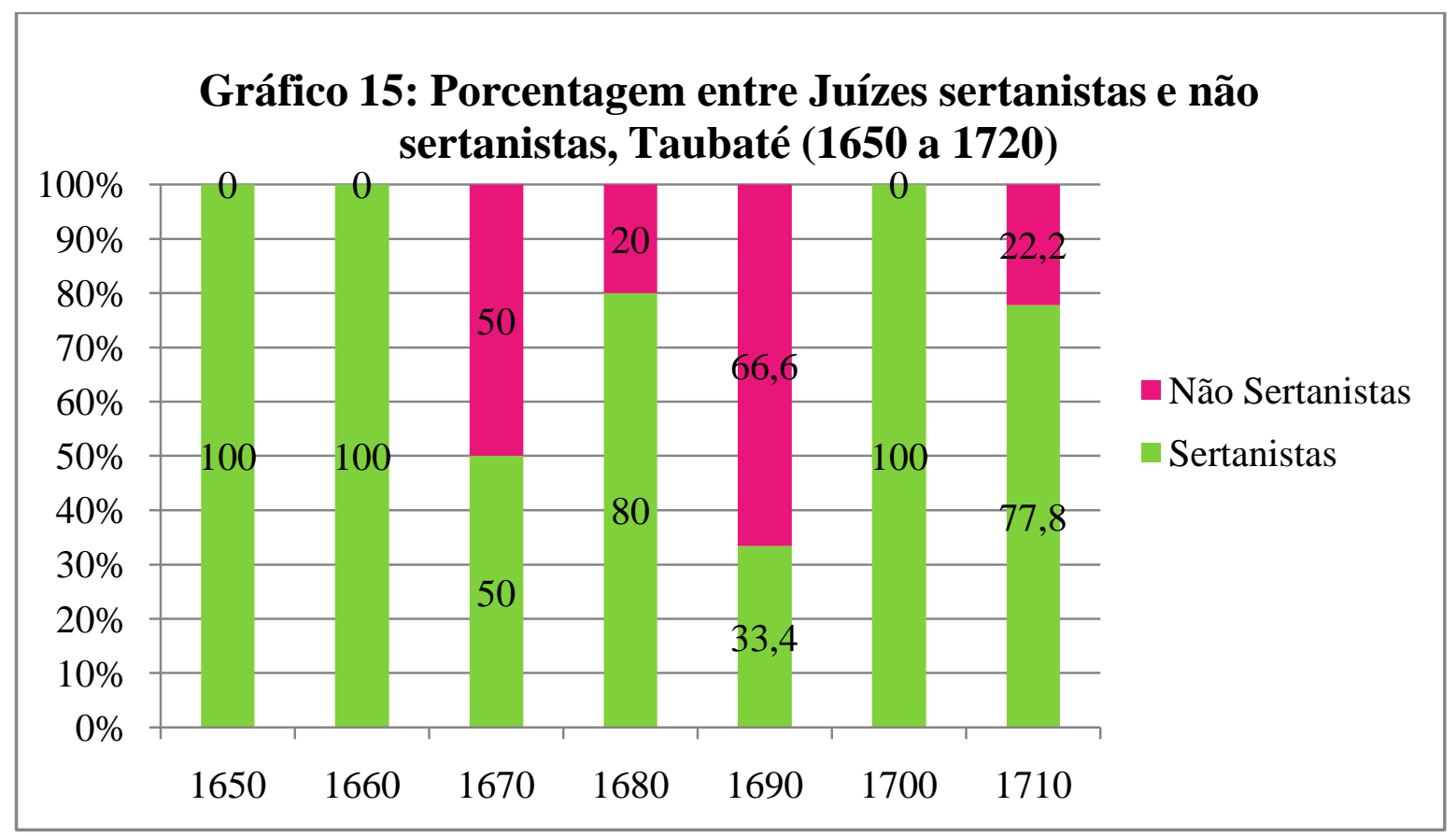

Fonte: Inventários (1649 a 1720). Arquivo Histórico Municipal de Taubaté.

O controle político absoluto exercido pelos bandeirantes pode ser constatado nas décadas de 1650, 1660 e 1700, enquanto que nas outras décadas, o poder esteve dividido com outras pessoas não ligadas ao movimento sertanista. Interessante notar que, durante esses momentos da não hegemonia bandeirante, fatores econômicos e sociais tiveram considerável influência. A começar pelas décadas de 1670, 1680 e 1690 que formam exatamente o auge das atividades sertanistas taubateanas. Foi neste bloco temporal que houve uma queda significativa na quantidade de bandeirantes presentes na vila, muito em função do grande número de expedições realizadas em direção ao sertão. O espaço deixado pelos sertanistas que estavam em viagens foi ocupado por outros indivíduos que até então não pertenciam ao grupo bandeirante local, o que acabou por quebrar o monopólio político deste grupo. E não foi só no campo administrativo, pois já se viu que o seu poder econômico também sofreu forte queda. Ressalta-se que não se pretende dizer com isso que os sertanistas perderam influência, mesmo porque é possível que tenham existido laços de 
afinidade entre sertanistas e não sertanistas. Assim, entende-se que a transferência do poder político para as mãos de pessoas não ligadas ao bandeirismo não significa a consolidação de um grupo rival frente ao tradicional grupo sertanista e muito menos a sua exclusão definitiva dos mecanismos de controle administrativo da vila.

Todavia, novamente fomentado pelo fluxo cotidiano de pessoas, a retomada da força política e econômica pelos sertanistas é notável na primeira década do século XVIII, devido à volta de muitos deles oriundos das minas. Mas esse quadro de retomada da hegemonia política e econômica por parte dos bandeirantes não durou muito tempo, já que na década seguinte, também outros indivíduos obtiveram sucesso financeiro com as novas oportunidades advindas com a exploração das minas. A maior distribuição de riquezas permitiu a qualificação social de outros indivíduos pretendentes ao exercício de cargos políticos, o que os colocou lado a lado com o tradicional grupo bandeirante que sempre esteve estacionado no núcleo do mando local. Percebe-se, então, uma tendência ao convívio no âmbito do poder local entre sertanistas e não sertanistas para a década de 1710.

A conquista de maiores parcelas no conjunto da riqueza local, ou seja, a expansão do cabedal familiar e a inserção no circuito principal de influência financeira da economia da vila era uma situação bastante favorável para a ocupação de cargos oficiais. Basta relacionar as trajetórias econômicas e políticas dos sertanistas para evidenciar tal característica.

O controle político local envolvia interesses econômicos e sociais, visto que podia beneficiar um dado grupo de pessoas frente ao restante da população. De fato, este controle podia representar, por parte de grupos de interesse, “(...) a consolidação de riqueza e poder, o que dava origem a disputas acirradas nas eleições locais durante todo o período." ${ }^{421} \mathrm{Em}$

${ }^{421}$ MONTEIRO, John Manuel. Negros da Terra: índios e bandeirantes nas origens de São Paulo. São Paulo: Companhia das Letras, 1994. p.110. Uma das diversas formas de favorecimento que podiam ser feitas através da posse de cargos camarários era o empréstimo de recursos financeiros pertencentes aos órfãos. O juiz dos órfãos, responsável pela administração dos bens dos órfãos, costumava emprestar a juros parte da riqueza destes. Monteiro considera que essa prática era "uma das principais fontes de crédito para os colonos". Idem, Ibidem. p.111. Para João Fragoso, o juizado dos órfãos constituía uma "poupança social". Cf. FRAGOSO, João. "A formação da economia colonial no Rio de Janeiro e de sua primeira elite colonial (séculos XVI e XVII)." In: FRAGOSO, João; BICALHO, Maria Fernanda Baptista; GOUVÊA, Maria de Fátima Silva (org.). O Antigo Regime nos Trópicos: a dinâmica imperial portuguesa (séculos XVI-XVIII). Rio de Janeiro: Civilização Brasileira, 2001. São muitos os registros desse tipo de empréstimos nos inventários dos bandeirantes de Taubaté. Essa fonte de recursos pode ter sido utilizada enquanto meio para 
Taubaté, pelo menos, não foi possível identificar disputas já que para o período analisado apenas um grupo dominou a governança. Ao que parece, somente na década de 1710 é que algo de diferente começou a surgir, capaz de causar certa preocupação nos sertanistas que formavam a elite da vila.

A melhor distribuição de riquezas serviu negativamente para o grupo bandeirante, pois viu crescer a força de outros indivíduos que não faziam parte do seu meio. Conscientes da diminuição do seu poder econômico, os sertanistas buscaram cada vez mais ocupar cargos no governo local, talvez como forma de manter o antigo status de elite, mesmo que isso permanecesse apenas no campo simbólico e dos privilégios. O gráfico seguinte mostra, através dos números, o crescimento do interesse pelos cargos no governo local por parte dos sertanistas taubateanos.

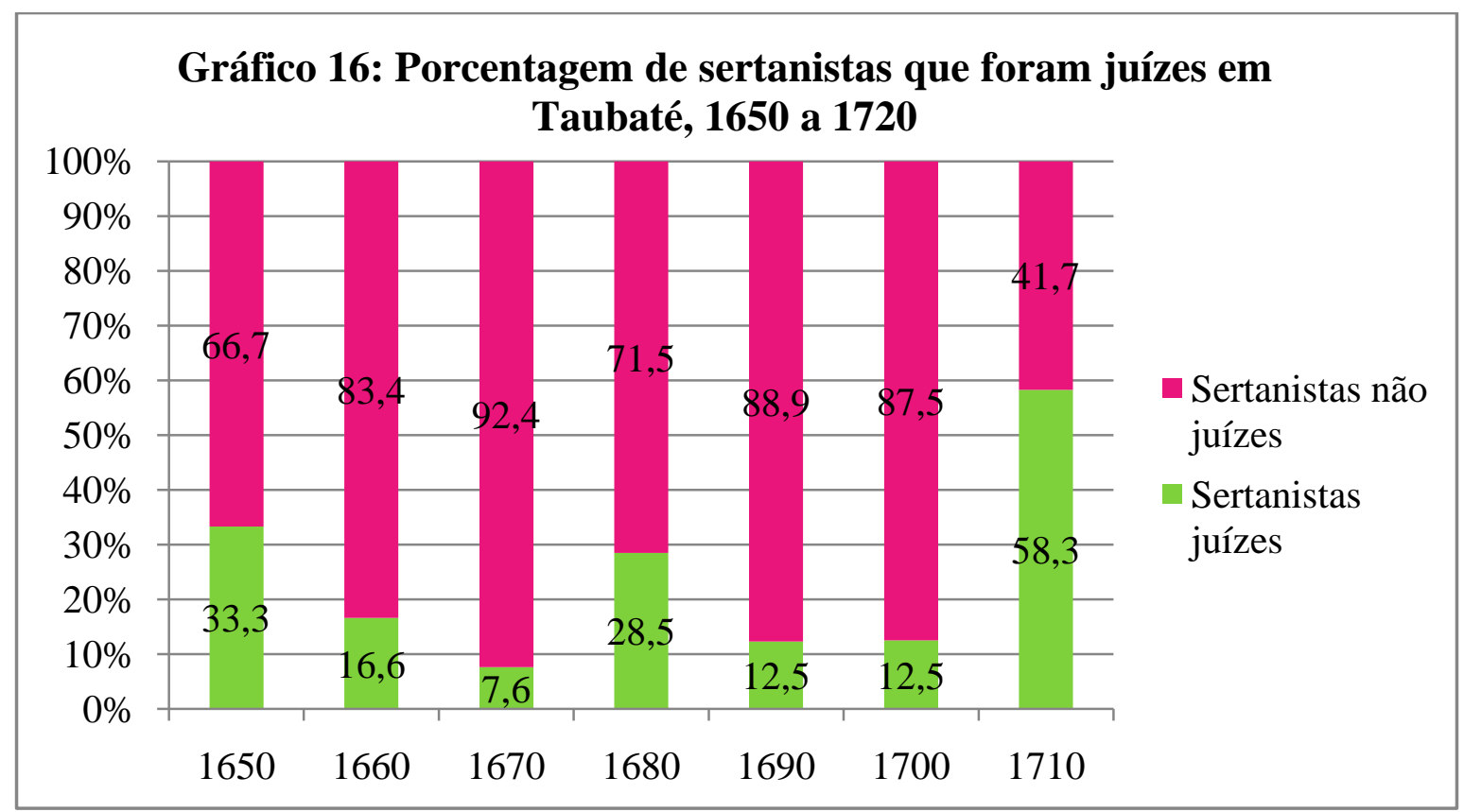

Fonte: Inventários (1649 a 1720). Arquivo Histórico Municipal de Taubaté.

viabilizar a organização e financiamento de expedições, mesmo porque os sertanistas possivelmente tinham facilidade na obtenção do crédito já que seus pares ocupavam os postos governamentais. Enfim, o cargo de juiz dos órfãos "dava ao homem que o ocupava o poder de dispor dos bens, mas sobretudo do dinheiro depositado no cofre dos órfãos, o que, em uma sociedade carente de liquidez, conferia-lhe muito poder. Não só porque, eventualmente, pudesse usar esses recursos em benefício próprio, mas também porque podia privilegiar aqueles que fossem de sua estima." ALMEIDA, Carla Maria Carvalho de. "Homens Ricos em Minas Colonial". In: BICALHO, Maria Fernanda; FERLINI, Vera Lúcia Amaral (org). Modos de Governar: idéias e práticas políticas no Império português (séculos XVI a XIX). São Paulo: Alameda, 2005. p. 382. 
Apesar do domínio local exercido pelos sertanistas, não eram todos que se interessavam pelos cargos oficiais. Verificou-se que a maioria dos que ocuparam a função de juiz ordinário e dos órfãos estavam entre os indivíduos mais ricos da vila. Talvez pela estabilidade financeira, pelo conforto familiar, os sertanistas de maior cabedal além de não mais adentrarem os sertões, preferindo investir financeiramente nas expedições, despertavam atenção ao exercício do poder político a fim de consolidar e manter sob controle a posição de mando do grupo como um todo e, principalmente, direcionar os esforços governativos no sentido de um favorecimento aos interesses de seu respectivo grupo. Da década de 1650 até a de 1700, a lucratividade das atividades sertanistas e o consequente controle político local fez com que o exercício dos cargos camarários ficasse sob a posse de não mais que $1 / 3$ do grupo bandeirante, quantidade suficiente para a manutenção do status do grupo.

Todavia, com o desenvolvimento da dinâmica econômica de Taubaté, com o enriquecimento de mais indivíduos e a ampliação do poder de influência local, a década de 1710 apresentou uma corrida dos sertanistas em direção aos cargos disponíveis na câmara. $\mathrm{Na}$ tentativa de manter a posição de elite local, o grupo sertanista recorreu em maior número de pessoas a ocupação dos ofícios políticos, situação representada no gráfico acima, o que mostra que nesta década nada menos do que 58,3\% dos sertanistas da vila passaram por aquela instituição. Se por um lado estava em declínio a sua força econômica, por outro o refúgio para o âmbito político ajudava a manter o seu status, mesmo porque "o poder sobre as pessoas é mais importante que o controle econômico. Através do primeiro se mantém o segundo." 422

Além da posse de cargos públicos, outra forma de exercer o controle sobre as pessoas era através da força militar. Como salientado no capítulo anterior, a posse de patentes militares não significava ascensão econômica, uma vez que mesmo os postos de oficiais das ordenanças não eram remunerados. O seu atrativo ficava por conta da influência exercida sobre a população através do processo de recrutamento militar, sendo que, muitas vezes, esta influência se dava pelo fator da intimidação.

422 ALVES, Maurício Martins. Caminhos da Pobreza: a manutenção da diferença em Taubaté (1680-1729). Taubaté: Prefeitura Municipal, 1999. p. 93. 
Numa sociedade como a paulista, neste caso a taubateana, cercada por todos os lados pelas práticas bandeiristas e que delas sobrevivia, a hierarquização das relações permeava o cotidiano, principalmente no dia-a-dia dos longínquos sertões. É sabido que “o sucesso da bandeira dependia inteiramente do cabo da tropa ou capitão do arraial, que tinha poder abosluto sobre seus subordinados, exercendo, também, as funções jurídicas no sertão."423 Enfim, seja na vila, seja no sertão, a patente militar ostentava poderes de comando e dava aos poucos que as possuía um status social bastante significativo.

\section{Gráfico 17: Porcentagem de sertanistas que tinham patentes militares, Taubaté (1650 a 1720)}

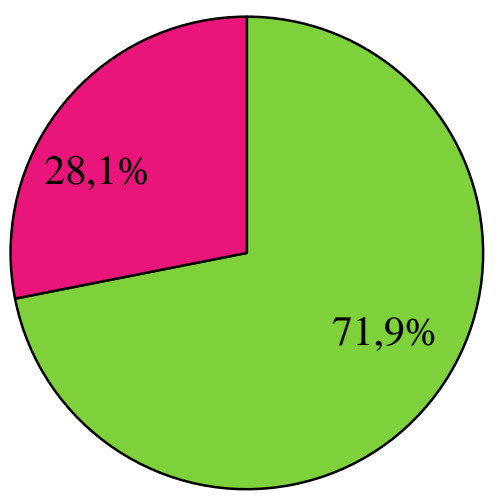

Sertanistas

Não-sertanistas

Fonte: Inventários (1649 a 1720). Arquivo Histórico Municipal de Taubaté.

Assim como para os cargos públicos, os sertanistas também detinham a maior proporção na posse de patentes militares, chegando a atingir 71,9\% do seu grupo. De modo geral, o acesso às patentes estava restrito a uma pequena parcela da população (cerca de $16,2 \%$ dela) e, como se vê, nesta minoria dominavam os bandeirantes. É possível que a maior facilidade que estes homens tinham na obtenção das patentes esteja ligada à própria condição social, isto é, já que predominavam os sertanistas na elite econômica local essas "diferenças sociais eram reforçadas no corpo do exército por meio das rígidas hierarquias", fazendo com que, freqüentemente, apenas pessoas com cabedal atingissem o posto de oficiais. $^{424}$

\footnotetext{
${ }^{423}$ KOK, Glória Porto. Op. cit. p. 45.

${ }^{424}$ Idem, Ibidem. p. 53.
} 
Além das condições sociais, a historiografia atual tem ressaltado a cobiça dos paulistas pela posse das patentes militares. Adriana Romeiro, por exemplo, entende que os paulistas se consideravam herdeiros de uma tradição guerreira que, desde os princípios da colonização da região, se empenharam no desbravamento do sertão, na luta contra os bárbaros e em serviços prestados à Coroa; logo, "não é à toa que as reivindicações dos paulistas pressupunham, invariavelmente, a concessão de patentes militares." ${ }^{425}$

Com certeza, todos esses fatores contribuíram para a permanência do domínio do grupo sertanista taubateano na posse das patentes militares ao longo de todo o período estudado.

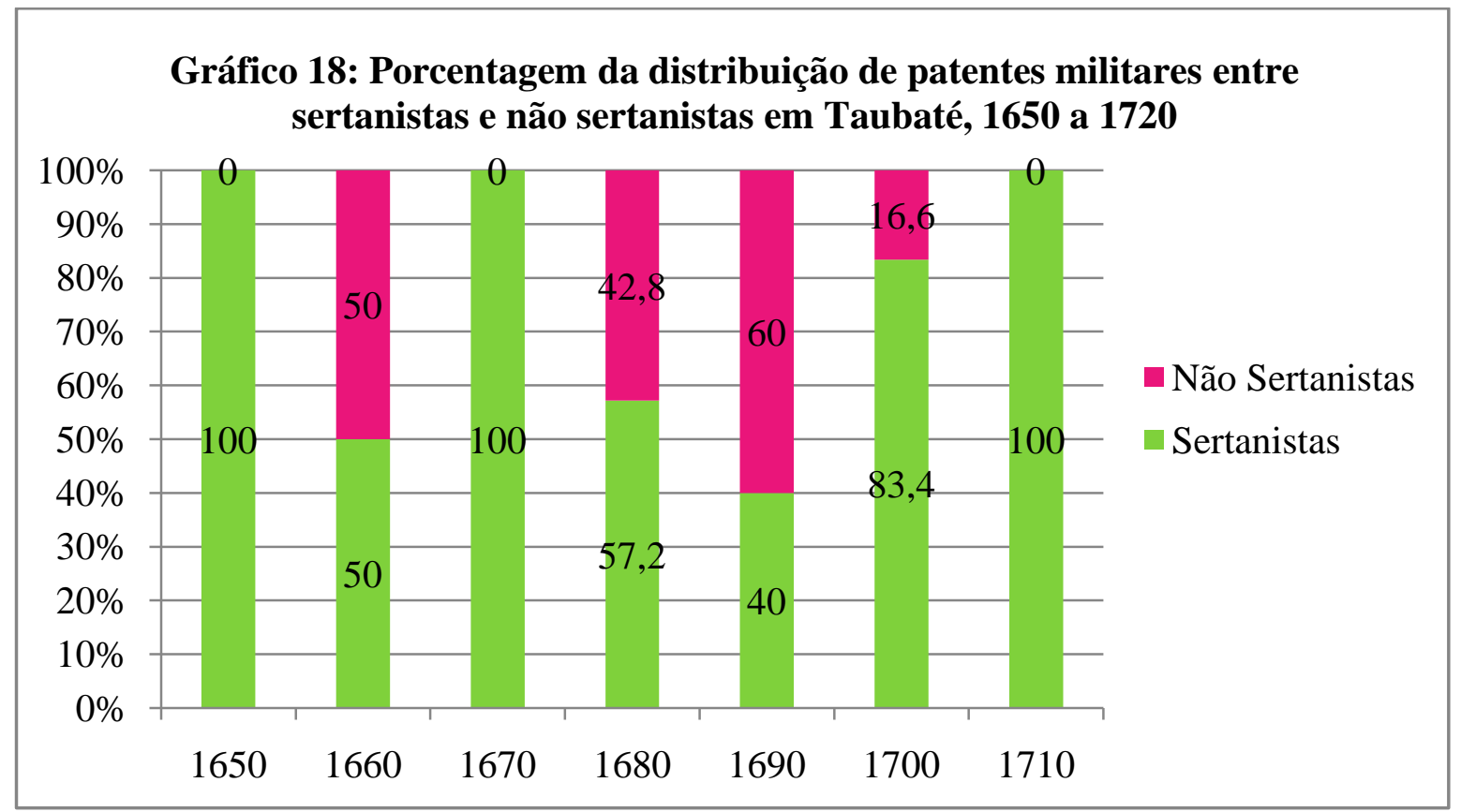

Fonte: Inventários (1649 a 1720). Arquivo Histórico Municipal de Taubaté.

${ }^{425}$ ROMEIRO, Adriana. "Revisitando a Guerra dos Emboabas: práticas políticas e imaginário nas Minas setecentistas". In: BICALHO, Maria Fernanda; FERLINI, Vera Lúcia Amaral (org). Modos de Governar: idéias e práticas políticas no Império português (séculos XVI a XIX). São Paulo: Alameda, 2005. p.395. Em outra interessantíssima obra, Romeiro enfatiza que "aos contemporâneos também causava impressão o culto, entre os paulistas, dos valores relacionados à guerra, como a coragem e a bravura, do que redundaria a tendência a se apresentarem como personagens de uma saga heróica, criando a versão histórica para a descoberta dos metais preciosos como um feito de bravura contra as adversidades de um sertão inóspito e adverso. É certo que a longa experiência de apresamento indígena - à qual se juntariam principalmente as guerras contra os bárbaros e os negros dos Palmares - incitou neles o alto apreço pelas qualidades guerreiras. E não é à toa que uma das recompensas mais almejadas eram precisamente as patentes militares e todas as forma de honraria que denotassem a coragem e a valentia." ROMEIRO, Adriana. Paulistas e Emboabas no Coração das Minas: idéias, práticas e imaginário político no século XVIII. Belo Horizonte: Editora UFMG, 2008. p. 237. 
Como sempre, os anos que antecedem a virada do século, com exceção da década de 1660, são os que apresentaram as maiores mudanças no quadro geral. Novamente, as andanças contínuas dos bandeirantes em direção ao sertão têm a ver com esta situação, pois a ausência deles, mesmo que momentânea, poderia dar espaço para outros indivíduos na ocupação de postos militares. Tanto é que na década de 1710 , com o retorno à vila de muitos destes sertanistas, agora sedentarizados devido à dedicação exclusiva às atividades econômicas ligadas à terra e à produção agrária e não mais preocupados com as andanças pelo sertão a procura de ouro e mão-de-obra indígena, a retomada do monopólio das patentes militares é evidente. Neste setor, ao contrário do político, a força do grupo sertanista pôde se manter, graças talvez às reivindicações que costumeiramente eram feitas solicitando a posse das patentes oficiais em seu próprio benefício visto que tinham o direito a elas, pois se consideravam os responsáveis pelo desbravamento dos sertões e a descoberta das minas de ouro. Além disso, a estima que estes homens tinham quanto à posse das patentes poderia não fazer parte dos desejos de outros indivíduos eventualmente não ligados às tradicionais atividades sertanistas.

Embora seja predominante a presença dos bandeirantes nos postos oficiais da estrutura militar local, não eram todos os que tinham acesso a eles.

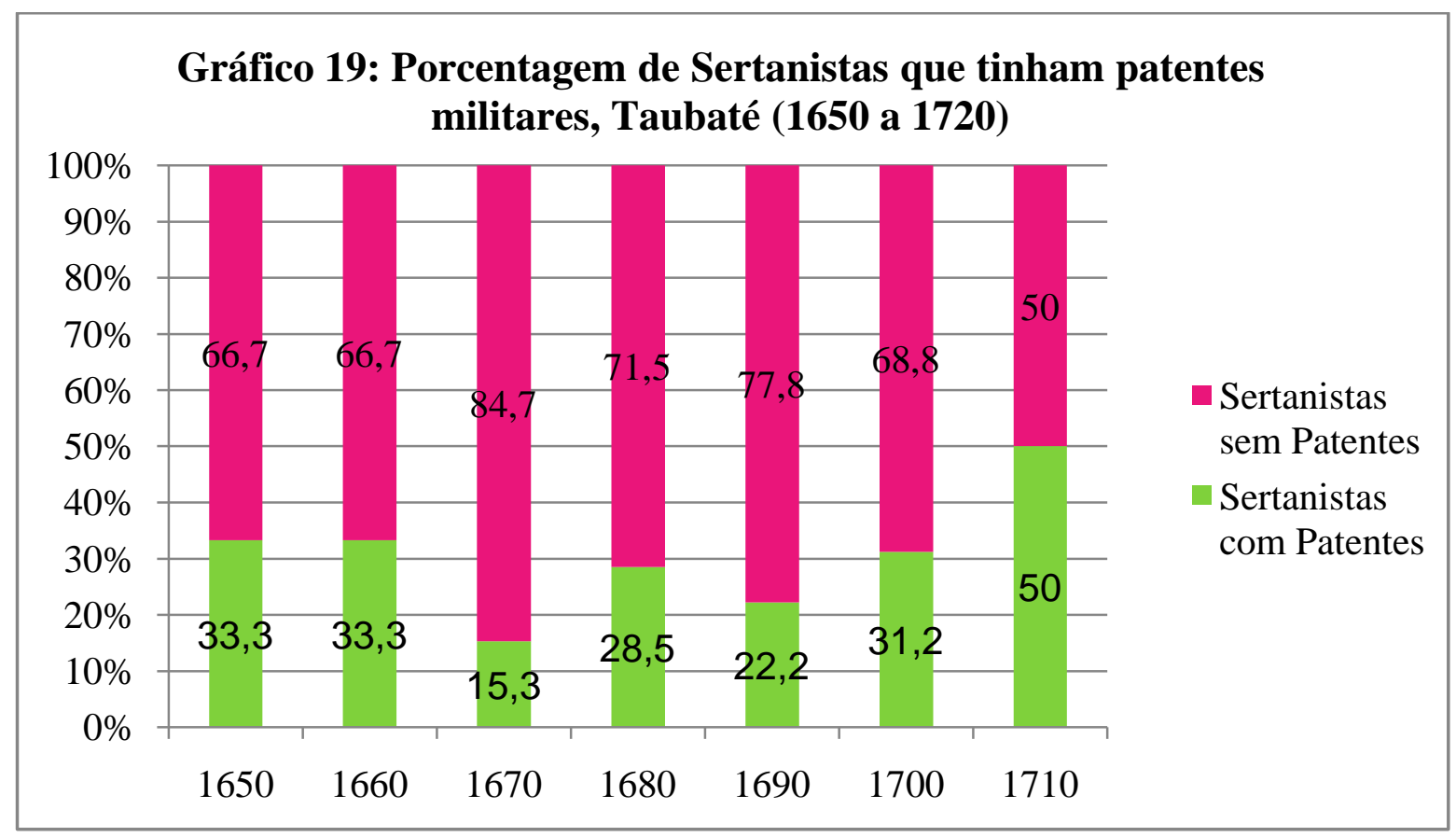

Fonte: Inventários (1649 a 1720). Arquivo Histórico Municipal de Taubaté. 
Da década de 1650 até a de 1700, não mais que 1/3 do grupo sertanista obteve as tão desejadas patentes. Esta limitação denota dois fatores: ou o número de postos existentes na vila correspondia justamente a esta taxa de ocupação e/ou as características sócioeconômicas dos bandeirantes determinavam o acesso de uns e a exclusão de outros. Ao se analisar o grau de riqueza dos sertanistas constatou-se que os mais ricos sempre tinham patentes militares, porém a distribuição destas entre os de menor poder aquisitivo também era possível. Na verdade, a riqueza ajudava na elevação do status de um indivíduo mas não era a única condicionante: o prestígio familiar obtido através da herença ou da união com outras famílias por meio dos casamentos, e a rede de relações sociais construída pelos laços afetivos e econômicos poderiam suprir a ausência de riqueza e dar ao pretenso oficial militar a condição digna para o exercício do cargo. Em outras palavras, o prestrígio social e a posição de "nobreza da terra" não necessariamente passavam pela abundância de riquezas.

À medida que terminava o século XVII e se iniciava o XVIII, a injeção de riquezas advindas da exploração mineral e dos tratos comerciais estabelecidos com as novas povoações formadas em torno das lavras possibilitou o enriquecimento da vila de Taubaté como um todo, suscitando num deslocamento no padrão econômico de muitas famílias que, dessa forma, deixaram para trás péssimas condições de vida, estabelecendo-se numa massa populacional que gravitava entre os mais pobres e os mais ricos. Embora não fossem os mais poderosos em termos econômicos, boa quantidade dos oficiais militares fazia parte desta parcela da sociedade, contribuindo, assim, para o crescimento na porcentagem de sertanistas que exerciam tais postos, o que pode ser verificado para a década de 1710.

Enfim, com a perda da hegemonia econômica, os sertanistas taubateanos recorreram cada vez mais à ocupação dos cargos camarários e à aquisição das patentes militares durante as primeiras décadas do setecentismo, o que indica, possivelmente, uma tentativa destes em manter o seu status de grupo dominante por meio do controle político e militar. 


\section{CAPÍTULO 4}

\section{CARLOS PEDROSO DA SILVEIRA - SERTANISMO E VIDA PÚBLICA}

Este capítulo foi pensado não com o objetivo único de discorrer sobre a vida de Carlos Pedroso da Silveira, mas também como meio de exemplificar algumas das características da colonização portuguesa em relação a São Paulo e ao movimento sertanista através de uma rápida biografia desse homem que viveu intensamente na fronteira que dividia os diferentes interesses advindos ou dos próprios colonos ou mesmo da metrópole.

$\mathrm{Na}$ verdade, pouco se sabe sobre ele. O que até agora foi escrito está disperso na bibliografia e ocupa apenas algumas páginas. Procurou-se, então, aglutinar as informações - não sem antes compará-las, é claro - a fim de chegar o mais próximo possível da ordem dos acontecimentos em que esteve envolvido.

Não obstante a escassez de informações acredita-se que a história de Carlos Pedroso é bastante significativa das ideias vigentes no Brasil colonial durante o período estudado nesta dissertação, principalmente porque tal história se confunde com a própria história da vila de Taubaté.

Enfim, sem outra intenção que não seja a de contribuir para o conhecimento histórico do sertanismo taubateano por meio de um de seus personagens, as páginas seguintes trarão dados biográficos encontrados na bibliografia e em alguns documentos disponíveis, inclusive seu testamento e inventário.

\subsection{Suas Origens}

Numa sociedade estamental as origens familiares de um indivíduo poderiam determinar o rumo tomado por este durante sua vida. $\mathrm{O}$ ingresso em atividades econômicas, a participação em grupos sociais e em redes de negócio, o envolvimento nos trâmites governamentais, a aquisição de símbolos nobiliárquicos, enfim, tudo isso dependia bastante da ascendência das pessoas. ${ }^{426}$

\footnotetext{
${ }^{426}$ Sobre as leis portuguesas, Júnia Ferreira Furtado lembra que "toda a legislação anterior [a 1773] considerava que a presença de um antepassado judeu ou cristão-novo em qualquer grau era suficiente para atestar impureza de sangue e impedir o exercício de cargos e a concessão de honrarias." Ressalta-se que a desqualificação social também se fazia pela prática de ofícios mecânicos. Cf. FURTADO, Júnia Ferreira. Homens de Negócio: a interiorização da metrópole e do comércio nas minas setecentistas. 2a ${ }^{\mathrm{a}}$. ed. São Paulo, Hucitec, 2006. p. 45.
} 
Logicamente que as ações das próprias pessoas não poucas vezes faziam-se necessárias e até mesmo suficientes para uma pretensa ascenção social e para o acesso a prática de atividades tidas como "enobrecedoras". No entanto, é evidente que as oportunidades eram muito maiores para aqueles que já desde cedo conviviam entre uma pequena parcela da sociedade que detinha o status de nobreza. De qualquer maneira, o passado, a tradição e a família eram prerrogativas importantíssimas para o futuro de um indivíduo. Nesse sentido, uma rápida exposição dos ancentrais de Carlos Pedroso pode ser muito útil para a compreensão das ações exercidas por este em vida.

Sabe-se, ao certo, que Carlos Pedroso nasceu na vila de São Paulo, como confirmado pelo mesmo em seu testamento. Por muito tempo considerou-se duvidosa a data, pois divergiam os autores quanto a isso. Carvalho Franco é da opinião de que teria sido no ano de 1654 , porém há quem diga que teria sido em $1664 .{ }^{427}$ De fato, após consulta a um dos textos existentes no conjunto de documentos com compõem um requerimento elaborado pelo próprio Pedroso, constatou-se que no ano de 1700 possuía 36 anos de idade, corroborando a tese de que seu nascimento se deu em $1664 .^{428}$

Era filho de Gaspar Cardoso Gutierrez, natural de Lisboa, e de Grácia da Fonseca Rodovalho, natural de São Paulo. Segundo Silva Leme, o primeiro era filho de Luiz Nunes Gutierrez, também natural de Lisboa, e de Maria Miguel da Silveira, natural da ilha Terceira, cidade de Angra. Esta foi tia do Dr. Jorge da Silveira, vigário geral e provedor do Bispado do Rio de Janeiro no ano de 1694. Já a mãe de Carlos Pedroso era filha de D. Simão de Toledo Piza, natural da ilha Terceita, cidade de Angra, e de Maria Pedrosa, filha

427 Cf. Inventário de Carlos Pedroso da Silveira (1719). Cx: 1716-1719. Arquivo Histórico Municipal de Taubaté. O testamento encontra-se anexado ao inventário; FRANCO, Francisco de Assis Carvalho. Dicionário de Bandeirantes e Sertanistas do Brasil. São Paulo: Comissão do V Centenário da Cidade de São Paulo, 1954. Verbete "Silveira, Carlos Pedroso da"; SILVEIRA, Carlos da. "Carlos Pedroso da Silveira". R.I.H.G.S.P. Vol. XXX. São Paulo: Typographia do Diário Oficial, 1935.

428 "Requerimento do Capitão-mor Carlos Pedroso da Silveira ao Rei [D. Pedro II], solicitando mercê do Hábito de Cristo com tença e a primeira Companhia de Infantaria paga que vagar [no Rio de Janeiro] pelos serviços prestados como Sargento-mor da vila de S. Francisco das Chagas de Taubaté, Ouvidor e Capitão-mor da Capitania de Nossa Senhora da Conceição de Tinhaém e Provedor das Minas e Quintos Reais da vila de Taubaté”. 28.01.1701. Arquivo Histórico Ultramarino - Conselho Ultramarino - Brasil/Rio de Janeiro. Cx. 7, doc. 741. p. 65 e 69. Citado a partir de agora apenas como "Parecer do Capitão-mor Carlos Pedroso da Silveira..." 
de Sebastião Fernandes Correa, primeiro provedor e contador da Fazenda Real da Capitania de São Vicente. ${ }^{429}$

Descendia então Carlos Pedroso da Silveira da união de duas famílias de conhecida nobreza, onde parte de seus membros se envolveu em famosas batalhas militares, ocupando altos postos, e se entrelaçando nas malhas administrativas do Império português, inclusive no Brasil, principalmente na capitania de São Vicente. ${ }^{430}$

${ }^{429}$ Cf. LEME, Luiz Gonzaga da Silva. Genealogia Paulistana. São Paulo: Duprat \& Comp., 1904. vol. 5, Título Toledos Pizas, p. 507-514.

${ }^{430}$ O avô materno de Carlos Pedroso, D. Simão de Toledo Piza, é um caso bastante emblemático. Reproduz Silva Leme uma descrição da vida deste homem feita por Pedro Taques, baseado em documentos registrados na vedoria da guerra da cidade de Angra da ilha Terceira: "Da ilustre casa dos condes de Oropeja e duques de Alba de Tormes foi legítimo descendente, sem quebra de bastardia dom João de Toledo Piza nascido na vila de Tormes, o qual casou em Madri com d. Ana de Castelhanos. Teve: Dom Simão de Toledo Piza que no posto de capitão tomou parte na batalha naval de Lepanto, em 1571, sob o comando de dom João da Áustria, contra os turcos, batalha que foi um terrível duelo entre o islamismo do turco que invadia a Europa e o cristianismo defendido pelas nações européias, e que teve como desfecho o triunfo completo do estandarte da cruz, perdendo os turcos 200 galeras, 25.000 homens e outros tantos escravos cristãos, que então foram postos em liberdade. No posto de Sargento Mor combateu em 1583, na armada sob o comando do general Álvaro de Bazan, marques de Santa Cruz, contra Monsieur de Chatres, cavaleiro de Malta, que da França veio em socorro dos moradores da ilha Terceira partidários de dom Antonio Prior do Crato, o qual, tendo se aclamado rei de Portugal em 1580, tinha já sido derrotado pelo exército de El-Rei Felipe II de Castela comandado por dom Fernando Álvares de Toledo, duque de Alba de Tormes: pelo que, tendo pedido esse socorro, veio Monsieur de Chatres aos mares da ilha Terceira onde experimentou uma derrota e ficaram os ilhéus dando obediência à Castela. Nesta batalha perdeu o Sargento Mor dom Simão um olho e para tratar-se ficou em Angra, onde casou com Gracia da Fonseca Rodovalho, irmã do deão da Sé dessa cidade - o Rabaço -, que instituiu o morgado no Pico Redondo, filhos de Vasco Fernandes Rodovalho. Teve de seu consócio quatro (4) filhos sendo duas fêmeas, que El-Rei de Castela fez recolher em um mosteiro em Madri com grande tença a cada uma delas e dois varões que foram: dom Gabriel de Toledo que, seguindo o real serviço, passou a Madri, e dom Simão que seguindo o mesmo serviço ficou na ilha Terceira; mais tarde chegando este ao posto de Capitão passou à corte de Madri donde saiu despachado e voltou a ilha Terceria. O que então lhe aconteceu ignoramos; entretanto, pelas declarações feitas em seu testamento em 1668 vemos que sofreu um revez de fortuna; disse ele: 'declaro que vindo de Madri despachado com os alvarás, que se acham na Provedoria da Fazenda, por secretos juízos do meu destino fui preso no castelo donde fugi e vim dar a esta Vila de São Paulo, onde casei e sempre cuidei em me não dar a conhecer, consentindo que o morgado, que por morte de minha mãe passava a mim, o tenha desfrutado e se ache de posse dele meu primo dom Pedro de Lombreiros, cônego da Sé de Angra, cujas cartas estão no meu contador com os mais papéis meus, e de meu pai e irmãos. Meu filho João de Toledo, habilitando-se por meu filho, irá a minha pátria para tomar posse do morgado que lhe pertence; cobrar da Fazenda Real o que consta das provisões que lá se acham em processo e também a minha legítima materna, que ficou em casas de sobrado.' Foi dom Simão de Toledo Piza pessoa de respeito e autoridade em São Paulo e teve sempre o primeiro voto no governo da república; adquiriu por seus méritos a propriedade do ofício de Juiz de Órfãos dessa Vila que exerceu com acerto e critério por 19 anos até 1661, ano em que lhe sucedeu nesse ofício Antonio Raposo da Silveira, como temos tratado no volume $3^{\circ}$, p. 05; foi Ouvidor da Capitania, 
Carlos Pedroso casou-se na vila de São Vicente com D. Isabel de Sousa Ebanos Pereira, natural do Rio de Janeiro, também pertencente a uma família de status elevado. Esta era filha de Gibaldo Ebanos Pereira, natural do Rio de Janeiro, e de Inês de Moura Lopes, natural de São Vicente. Era também neta paterna de Heliodoro Ebanos, natural de Viana do Minho e primo irmão de Estácio de Sá com quem viera ao Rio de Janeiro em 1568, e foi casado com Maria de Sousa Brito, filha do famoso João de Sousa Pereira Botafogo, natural de Elvas, e de Maria da Luz Escórcia Drumond.

É preciso abrir um espaço aqui para uma pequena nota sobre João de Sousa Pereira Botafogo, pois, ao que tudo indica, foi onde a prática sertanista se iniciou na família. Mais uma vez, conta-se com a ajuda de Silva Leme:

Era este João de Sousa Pereira Botafogo natural de Elvas onde seus pais $e$ avós tiveram casa que foi confiscada por ordem régia, por causa de usas insistências e soberbas resistências à Justiça e outros motivos pelos quais foram perseguidos. Alcançou esta perseguição a João de Sousa Pereira, como membro da família; porém, como há esse tempo a rainha deixava passar em paz aos criminosos que vinham à conquista de índios bravos no Brasil, passou ele com esse intento ao Rio de Janeiro, quando se fazia aí a guerra contra o gentio Tamoio. Como este Botafogo era destemido e de reconhecida nobreza foi feito capitão de uma das canoas de guerra e mandado a Cabo Frio a impedir o contrato do pau brasil em que os franceses estavam comerciando. Foi tão feliz nessa empresa que, pelejando com valor e ousadia com os franceses, conseguiu vencê-los fazendo prisioneiros entre outros a Tucem Grugel cabo da armada, valoroso francês, que foi levado ao Rio de Janeiro e foi o tronco dos Amarais Gurgeis daquela cidade e que depois se espalharam em São Paulo. Do Rio de Janeiro passou a São Vicente onde também a guerra contra os bárbaros gentios andava ateada e, mostrando o seu valor e destreza militar o tomou por genro o Capitão do presídio Manoel da Luz. Escorcia Drumond. ${ }^{431}$

De fato, o casamento de Carlos Pedroso com Isabel de Sousa Ebanos Pereira consolidou a união de duas famílias que, desde o primeiro século de colonização do Brasil, estavam inseridas num seleto grupo social detentor de alto prestígio social visto que

cargo de que tomou posse em 1666; em todas as ocasiões de rebate acudiu com sua pessoa e gente de serviço, a sua custa, à Vila de Santos, e quando da Bahia se pediram mantimentos ele, além do que de sua casa dava, instava com os mais moradores a que fizessem o mesmo. Alegando os seus serviços a Sua Majestade assim nas armadas como nos presídios, o que mostrava pelas certidões e fés de ofício, obteve uma sesmaria de uma légua de terra para suas lavouras." LEME, Luiz Gonzaga da Silva. Op. cit. vol. 5. p.445-446. Cf. também LEME, Pedro Taques de Almeida Paes. "Nobiliárquia Paulistana: histórica e genealógica." vol. 2. In: R.I.H.G.B. Tomo Especial. Rio de Janeiro: Imprensa Nacional, 1926. p. 185-190.

${ }^{431}$ LEME, Luiz Gonzaga da Silva. Op. cit. vol. 5. p. 508-509. 
possuíam não apenas riquezas materiais, mas, sobretudo, patentes militares e cargos na governança. A longevidade da presença de ambas as famílias no circuito político, administrativo e financeiro colonial lhes conferiu um caráter "tradicional", isto é, o status observado nas duas famílias desde os pioneiros vindos da Europa pôde, ao longo do tempo, dar aos seus descendentes as oportunidades para a reprodução deste mesmo status, senão até elevá-lo ainda mais. Em relação aos primeiros colonizadores, aos membros da administração colonial, aos participantes de lutas contra estrangeiros e bárbaros que ameaçaram o processo de colonização do Brasil, eram os filhos, os netos e os bisnetos representantes de algumas das principais famílias que estiveram presentes em tal processo, recebendo por isso mesmo o status de "tradicionais".

Nesse contexto, a reprodução da condição social era determinante para a perpetuação da tradição familiar, logo, o casamento se constituiu como uma forma bastante eficaz para tal objetivo. Foram muitas as situações em que a união matrimonial serviu para assentar as bases de uma nova geração sem que as antigas estruturas econômico-sociais fossem desfeitas. Ao contrário, o casamento era colocado em prática não apenas com o intuito da manutenção dos poderes e das riquezas, mas também, em grande medida, como veículo que possibilitava o acesso aos núcleos mais elevados da sociedade, o que permitia a afirmação de um determinado indivíduo em termos de valores sociais tanto entre seus próprios pares como perante a sociedade em geral.

A importância do casamento e, consequentemente, do dote era tamanha que chegavam a fazer parte da estratégia de uma "engenharia política", como sugere João Fragoso. ${ }^{432}$ Para ele, a formação de uma rede de reciprocidades consolidada por meio das alianças era viabilizada majoritariamente pelos casamentos e pelas políticas parentais. No caso das famílias que desejavam garantir a hegemonia sobre a sociedade, o caminho da união matrinomial era bastante seguro e eficaz. Tal recurso estava tão enraizado nas práticas cotidianas da população colonial que é possível vê-lo em diferentes lugares

\footnotetext{
${ }^{432}$ FRAGOSO, João. "A formação da economia colonial no Rio de Janeiro e de sua primeira elite senhorial (séculos XVI e XVII)." In: FRAGOSO, João; BICALHO, Maria Fernanda Baptista; GOUVÊA, Maria de Fátima Silva (org.). O Antigo Regime nos Trópicos: a dinâmica imperial portuguesa (séculos XVI-XVIII). Rio de Janeiro: Civilização Brasileira, 2001. p. 54.
} 
dispersos ao longo do tempo, sendo modificadas apenas suas estratégias de acordo com as conjunturas históricas. $^{433}$

No caso da união entre Carlos Pedroso da Silveira e Isabel de Sousa Ebanos Pereira é possível que interesses extraconjugais, além da relação afetiva entre ambos, tenham servido de motivação, talvez a busca pela manutenção do status de ambas as famílias fosse um deles. Tanto de um lado como de outro a participação de parentes no diversos setores da administração colonial, possuidores de patentes militares e de cargos políticos, significava o acesso direto aos principais meios de ascensão social. Como se viu, muitos membros das duas famílias em questão tiveram lugar reservado nos círculos sociais mais disputados pela população colonial. Nesse sentido, nascer, crescer e depois formar laços matrimoniais entre pares era o esquema básico para a garantia do status tradicional familiar.

Apesar das pouquíssimas páginas dedicadas à trajetória de vida de Carlos Pedroso, sabe-se que exerceu desde muito cedo cargos administrativos e militares. Ao que tudo indica, a tradição familiar se manteve através dele, facilitando inclusive o seu ingresso no círculo social detentor do mando local e regional.

\subsection{Sertanista, militar e político}

A participação de Carlos Pedroso da Silveira nos negócios sertanistas é certa opinião esta generalizada na historiografia brasileira. No entanto, não se tem maiores informações sobre as formas de tal participação, sobre as datas dos acontecimentos e muito menos sobre as expedições propriamente ditas. $\mathrm{Na}$ verdade, assim como a grande maioria das ações dos bandeirantes e de suas empresas, as atividades sertanistas nas quais Carlos Pedroso esteve envolvido ficaram no esquecimento. Não é nenhuma novidade que apenas algumas das muitas expedições organizadas pelos paulistas são conhecidas, somente as mais famosas, seja por seu grande volume de pessoas, seja pelo registro em documentação, seja pela repercusão gerada no momento dos fatos, seja pela notícia de sucesso ou de fracasso, enfim, foi apenas uma pequena parcela do movimento sertanista que se gravou nas linhas da memória.

433 A obra de Sheila Faria contém ótimas reflexões sobre o comportamento social diante do matrimônio juntamente com as regras e as condicionantes vigentes no período colonial do Brasil. Cf. FARIA, Sheila de Castro. A Colônia em Movimento: fortuna e família no cotidiano colonial. Rio de Janeiro: Nova Fronteira, 1998. 
Como se verificou no capítulo anterior, estudar a história do bandeirismo é, de fato, ir ao encontro de uma história dos anôminos. Mesmo sendo considerado "a principal figura de todo o primeiro período do grande ciclo do ouro em Minas Gerais" ${ }^{434}$, o passado de Carlos Pedroso é bastante desconhecido. Não sem razão Afonso Taunay, ao tratar das bandeiras de prospecção e de Carlos Pedroso, denuncia que "aparece aí, em situação até hoje não destrinçada um dos mais famosos personagens envoltos nos fastos dos primeiros descobertos." ${ }^{435}$ As palavras de Taunay continuam a valer mesmo após meio século depois de escritas.

Ao que se sabe, Pedroso já estava envolvido com as empresas sertanistas desde a década de 1680. Foi, todavia, consagrado pelos acontecimentos que tiveram lugar somente na década seguinte.

Ao mesmo tempo em que ingressava como sócio em tais empresas, exercia cargos políticos e militares. Revela Vasconcelos que "apesar de muito moço, quando se associou à empresa dos descobrimentos, já tinha exercido o cargo de Sargento-mor de Taubaté, e de Ouvidor da capitania de Itanhaém." ${ }^{436}$ Ocupou o primeiro destes cargos pelo tempo de dois anos, entre junho de 1692 e 1694, por meio de um provimento do Capitão-mor Martim Garcia Numbria, e exerceu o segundo apenas por seis meses por provimento do Capitãomor Cristóvão Azeredo Barreto.

Convém observar que o conjunto de atividades exercidas por ele pode ser considerado um indicativo da sua vantajosa condição sócio-econômica, muito em função dos valores materiais e imateriais oriundos da sua tradição familiar. A disponibilização de cabedal financeiro, o mínimo grau de instrução educacional e a localização eminente dentro do quadro estamental da sociedade eram fundamentais para o preenchimento dos quesitos básicos exigidos para a ocupação dos cargos indicados acima e a participação nos empreendimentos de caráter econômico. Somente um elevado status herdado poderia dar ao ainda jovem Carlos Pedroso o instrumental necessário para a prática dessas funções políticas, econômicas e militares.

\footnotetext{
${ }^{434}$ FRANCO, Francisco de Assis Carvalho. Op. cit. p. 381.

${ }^{435}$ TAUNAY, Affonso de E. História das Bandeiras Paulistas. São Paulo: Edições Melhoramentos, Tomo I, $2^{\text {a }}$ Edição, 1961. p. 216.

${ }^{436}$ VASCONCELOS, Diogo de. História Antiga das Minas Gerais. 3ª ed. vol. 1. Belo Horizonte: Itatiaia; Brasília, INL, 1974. p. 206.
} 
Fica em evidência a forte ligação entre Carlos Pedroso e a vila de Taubaté, principalmente a partir da década de 1690, quando passou aí residir. Em seu inventário, datado de 18 de agosto de 1719, feito na dita vila, seus herdeiros declararam seus bens de raiz, que eram: "um sítio em a paragem chamada Mombaça com duzentas braças de terras mais as vargens do Paraíba com casas de taipa de pilão cubertas de telha de dois lanços grandes assoalhados com seus corredores de parte a parte" e "uma tacanisa e três lanços de casas de hóspedes também de taipas cubertas de telha todo amurado". Além disso, "uma morada de casas nesta vila na rua dos Gizes em chãos do Conselho pegado a cadeia com dois lanços e seu corredor cubertas telha e paredes de mão", e mais seis braças de chãos em frente a mencionada casa. ${ }^{437}$ Note-se, de imediato, o acesso de Pedroso aos chãos pertencentes ao Conselho, o que denota a sua vinculação ao grupo dominante que controlava a política local através de tal instituição. Já que "a Câmara também tinha um papel importante na distribuição de sesmarias, ficando encarregada em definir quais solicitantes estavam aptos a receber as terras pedidas" ${ }^{238}$, inclusive terras dentro do perímetro da vila, chamadas de "cartas de datas", significa que fazer parte direta ou indiretamente do centro das decisões políticas locais era condição extremamente proveitosa, visto que o deferimento de pedidos sofria o peso da influência exercida pelo solicitante. É de se supor que Carlos Pedroso tivesse o reconhecimento da elite local.

O enraizamento dos seus interesses em Taubaté se fez em termos econômicos, sociais e políticos. Em se tratanto de atividades produtivas e sobrevivência econômica, seu inventário traz algumas informações valiosas. Nele, ao descrever o sítio acima mencionado, está registrado a posse de alguns objetos que indicam a preferência de Carlos Pedroso dentro do setor agrário. Como de praxe, é possível encontrar o arrolamento de plantações destinadas primeiramente à subsistência da própria família como o cultivo de mandioca e de milho, condição esta confirmada através da presença de utensílios destinados ao preparo de tais produtos, a saber: "uma roda de ralar mandioca" e "uma prensa de espremer massa."439 Além disso, havia a então próspera e rentável cultura da cana-de-açúcar que,

437 Inventário de Carlos Pedroso da Silveira (1719). Cx: 1716-1719. A.H.M.T. O testamento encontra-se anexado ao inventário.

${ }^{438}$ CÂMARA, Leandro Calbente. Administração colonial e poder: a governança da cidade de São Paulo (1765-1802). Dissertação de Mestrado. FFLCH-USP, 2008. p. 108.

${ }^{439}$ Inventário de Carlos Pedroso da Silveira (1719). Cx: 1716-1719. A.H.M.T. 
como se viu anteriomente, estava em alta após a virada do século XVII para XVIII. ${ }^{440}$ Apesar do cultivo da cana figurar no rol dos produtos escolhidos pelos habitantes da vila de Taubaté desde muito cedo, foi somente com a abertura de novos mercados consumidores localizados nas recém-descobertas Minas Gerais que se pôde constatar uma ampliação no sistema produtivo muito em função da sua valorização. A crescente demanda pela cana e seus derivados, máxime a aguardente, fez com que muitas pessoas iniciassem o cultivo dela e é bem provável que Carlos Pedroso tenha sido um destes indivíduos. Numa escritura de dívida contraída por ele, datada de 3 de outubro de 1707, onde deu por garantia o dito sítio do "Mombaça", não há a menção do cultivo de cana, muito menos do seu preparo, apenas a criação de trinta cabeças de gado vacum. ${ }^{441}$ No entanto, consta em inventário, feito em 1719, possuir "um quartel de cana capaz de moer", "um quartel de cana plantado de novo", e para o seu preparo "uma moenda", "um alambique de cobre de uma arroba de peso com seu capelo e cano", "dois tachos" e, por último, "um forno de cobre com vinte oito libras de peso." ${ }^{442}$ Enfim, a produção agrária de Pedroso sofreu um processo de mercantilização devido talvez não apenas ao fato da oportunidade de maiores lucros mas também como forma segura de investimento para os seus recursos financeiros, sem falar na possibilidade de ostentação do status de "senhor", visto que também ocorreu a transferência da sua escravaria, antes constituída inteiramente por índios, agora composta somente por negros africanos. ${ }^{443}$ Parece que tal mudança acompanhou as transformações ocorridas na vila como um todo, notadas principalmente na mercantilização de sua produção, na queda da atividade sertanista voltada para a captura de silvícolas e na maior dinamização da economia com a disponibilização de parte da riqueza por meio dos empréstimos.

Ainda dentro do universo agrário de Pedroso, suas atividades econômicas também lidavam com a produção de telhas já que seus herdeiros mencionaram a posse de "um forno de fazer telhas". ${ }^{444}$ Porém, os seus negócios não estavam restritos às cercas do seu sítio.

Para ele as oportunidades de negócios iam além da produção extraída da típica estrutura agrária montada pelo processo colonizatório lusitano em terras brasileiras.

\footnotetext{
${ }^{440}$ Cf. gráfico 2 na página 94.

${ }^{441}$ Livro de Registros e Escrituras Cx: 158. (1700-1711). Doc. 04. f. 4 e 5.

${ }^{442}$ Inventário de Carlos Pedroso da Silveira (1719). Cx: 1716-1719. A.H.M.T.

${ }^{443}$ De acordo com os documentos citados nas notas anteriores, em 1707 possuía 55 índios, já em 1719 eram 20 negros africanos.

${ }^{444}$ Inventário de Carlos Pedroso da Silveira (1719). Cx: 1716-1719. A.H.M.T.
} 
Logicamente que a base da economia colonial estava assentada no setor rural, ou seja, nas plantações e criações de animais. Tais atividades eram, sem dúvida, o meio mais acessível e o mais praticado pelos colonos, seja com vistas ao próprio sustento, seja com vistas ao lucro através do comércio. A participação no circuito produtivo agrário atingia grande parcela da população de Taubaté. Não havia restrições. Os bandeirantes, inclusive, utilizavam-se dos índios escravizados para aumentar as suas produções. Carlos Pedroso fez, sem dúvida, parte deste ambiente e dele se sustentou. Todavia, outras atividades atraíram sua atenção.

Em 6 de agosto de 1693, havia pouco tempo instalado na vila de Taubaté e exercendo o cargo de Sargento-mor dela, Pedroso registrou em documento cartorário uma "escritura de contrato dos dízimos" da sobredita vila. O Contratador Real dos Dízimos das Capitanias de Nossa Senhora da Conceição de Itanhaém e de São Vicente, José Nunes de Siqueira, através de seu procurador, o capitão Antonio de Oliveira Guimarães, arrendou "ao Sargento-mor Carlos Pedroso da Silveira os dízimos desta dita vila de Taubaté em preço e quantia de 280\$000 os quais serão pagos em quartéis a saber: noventa e três mil e trezentos e trinta e três por ano que pelo dito Sargento-mor foi aceito", e mais, se "obrigou aos ditos pagamentos sua pessoa e bens móveis e de raiz havidos e por haver assim ao presente como ao diante presentes e futuros". ${ }^{445}$ Por fim, nomeou por fiadores o capitão Pedro Leme do Prado $^{446}$, o capitão Pedro da Fonseca Magalhães, o capitão Manoel da Fonseca, Paulo da Costa Agostim e Antonio da Costa Agostim ${ }^{447}$; gente do seu círculo de amizade e confiança, alguns deles conhecidos sertanistas. Já em 28 de setembro de 1695, Carlos Pedroso cumpre com o prometido, dá por quitada a dívida e manda registrar um termo dela, "desobrigando a seus fiadores da fiança dos dízimos". 448

Vale lembrar que o dízimo, "imposto de um décimo de toda a produção pago à Igreja, no Brasil era arrecadado em favor do monarca, dada sua condição de mestre da

\footnotetext{
${ }^{445}$ Livro de Registros e Escrituras Cx: 157 (1676-1700). Doc. 03. f. 5 e 6.

446 "Paulista, irmão de Diogo Barbosa Leme, tomou parte na bandeira de Antônio Raposo Tavares em 1636 ao sul brasileiro e foi companheiro de Fernão Dias Pais na sua jornada à Sabaráboçú, desde 1674 até 1681." FRANCO, Francisco de Assis Carvalho. Op. cit. p. 315.

447 "Sertanista de São Paulo que tomou parte numa bandeira chefiada por Jerônimo Pedroso de Barros e que foi toda destroçada em Mbororé, no sul brasileiro, em 1641." Idem, Ibidem. p. 13.

${ }^{448}$ Livro de Registros e Escrituras Cx: 157 (1676-1700). Doc. 03. f. 26.
} 
Ordem de Cristo". ${ }^{449}$ A falta de documentação sobre o recolhimento de tal imposto taxado sobre a produção de Taubaté impossibilita o estabelecimento exato, ou pelo menos aproximado, dos valores arrecadados. No entanto, se levar em conta que o dízimo era calculado sobre toda a produção local, e que no momento do contrato - 1693 a 1695 - a economia taubateana se remodelava em virtude das notícias sobre as minas de ouro e a constituição de um novo mercado consumidor, é lícito pensar que foi vantajosa a arrematação deste imposto. De qualquer forma, Carlos Pedroso viu neste contrato uma oportunidade de auferir maiores lucros.

Ainda sobre o universo econômico de Pedroso, o envolvimento em dívidas parece ter sido uma constante em sua vida. Não são poucos os registros de dívidas tanto ativas como passivas que o nomearam como um dos indivíduos ligados a esses negócios, principalmente após a virada do século XVII para o XVIII, quando aumentam os recursos financeiros disponíveis no mercado local derivados das Minas Gerais, além do aquecimento da própria dinâmica econômica da vila que impulsionou muitos indivíduos a investirem em novas atividades produtivas e comerciais, ocasionando com isso, a crescente procura por crédito.

Sabe-se que em 25 de março de 1702, Carlos Pedroso solicitou a Domingos de Sousa Barros o empréstimo de nada menos que 1:016\$000 réis, quantia esta entregue com a condição de correr em juros de $8 \%$ ao ano, como de praxe. Dois anos depois, em 25 de maio de 1704, Pedroso passou a ser credor. Emprestou ao Capitão Sebastião de Siqueira Gil o valor de $746 \$ 000$ réis sob juros costumado. Aliás, há uma nota no próprio registro que diz estar a dívida em vigência já em tempo de três anos e quatro meses, assim, rendendo de juros $198 \$ 972$ réis para o credor. Em anos seguintes, encontra-se novamente sendo devedor de mais duas dívidas, uma datada de 3 de outubro de 1707 e outra em 4 de março de $1708 .^{450}$ Na primeira tomou 10.000 cruzados $^{451}$ emprestados de Domingos Cordeiro por

\footnotetext{
${ }^{449}$ Sobre a prática da concessão do direito de cobrança de impostos através de contratos firmados com particulares vigente nas monarquias do Antigo Regime, depois transferida para suas colônias, Cf. OSÓRIO, Helen. "As elites econômicas e a arrematação dos contratos reais: o exemplo do Rio Grande do Sul (século XVIII)." In: FRAGOSO, João; BICALHO, Maria Fernanda Baptista; GOUVÊA, Maria de Fátima Silva (org.). O Antigo Regime nos Trópicos: a dinâmica imperial portuguesa (séculos XVI-XVIII). Rio de Janeiro: Civilização Brasileira, 2001. p. 109-137.

${ }^{450}$ Cf. Livro de Registros e Escrituras Cx: 158 (1700-1711). Doc. 01. f. 78; Doc. 02. f. 6, f. 2, Doc. 04. f. 4, respectivamente.
} 
tempo de dois anos sob juros, para tanto hipotecou o seu sítio de Mombaça - já descrito neste capítulo -, e na segunda pegou 1:228\$800 réis de Juliana de Oliveira, também sob juros, e para a consumação do negócio deu por seu fiador um dos mais importantes bandeirantes da vila, o capitão Bartolomeu da Cunha Gago. ${ }^{452}$

O importante nisso tudo não é apenas observar tais dívidas como aspectos da vida econômica de Pedroso, mas também como meio bastante interessante para se constatar as relações sociais estabelecidas por ele. Nesse contexto, as redes sociais eram indispensáveis para o desenvolvimento tanto dos negócios como para a afirmação dos status dos indivíduos, isto é, o relacionamente entre as pessoas e o estabelecimento de laços parentais e clientelares eram extremamente necessários para a consolidação do posicionamento na vida pública, tanto no campo econômico como na localização em meio à sociedade em geral. Como se viu, a aquisição de dívidas acarretava, quase sempre, na nomeação de um fiador que se responsabilizava pelo cumprimento do trato pelo devedor, dando como garantia parte de sua riqueza. Isso quer dizer que o fiador depositava sua confiança no contratante a ponto de arcar com a dívida caso este não efetivasse o pagamento. Carlos Pedroso parece ter sido um homem de extensa confiança, pois, além de ter à sua disposição fiadores que o amparavam quando precisava, também se disponibilizou por diversos momentos como fiador de muitas pessoas, o que mostra a existência de relações sociais muitas vezes sustentada por práticas de obrigatoriedade de uns para com outros, numa espécie de "reciprocidade devida", normalmente regulada de forma tácita. ${ }^{453}$ Somente entre os anos de 1699 e 1702 foram registradas dez escrituras de dívidas nas quais Pedroso se dispôs a ser fiador. Vale lembrar que tais dívidas não se restringiam apenas a um negócio local, haja vista que algumas delas foram efetuadas por pessoas identificadas como sendo

${ }^{451}$ Um cruzado é o equivalente a 400 réis. Portanto 10.000 cruzados correspondem a 4:000\$000 contos de réis.

${ }^{452}$ Bartolomeu da Cunha Gago: paulista, filho do homônimo Bartolomeu da Cunha Gago e Maria Portes de El-Rey, acompanhou D.Rodrigo de Castelo Branco em 1681 ao sertão das Minas Gerais e andou posteriormente descobrindo ouro em Aiuruoca e Baependi. Casou com Margarida Bueno da Veiga de Mendonça e faleceu em 1710 deixando geração. Cf. FRANCO, Francisco de Assis Carvalho. Op. cit. p. 170.

${ }^{453}$ É o que se vê na já citada dívida de 1:016\$000 conto de réis contraída por Pedroso, datada de 25 de março de 1702, quando deu por fiador o Capitão Belchior Félix Correa. No mês seguinte, no dia 24, por sua vez aparece o dito Capitão tomando emprestado a quantia de $286 \$ 000$ mil réis e dando por seu fiador Carlos Pedroso, ou seja, o favor foi pago com outro favor. Cf. Livro de Registros e Escrituras Cx: 158 (1700-1711). Doc. 01.f. 79 e 80. 
moradoras em Parati, Ilha Grande e São Paulo, e, em termos de atividade econômica, não se limitavam a nenhum tipo específico de grupo, isto é, tem-se relações com sertanistas, com produtores agrícolas e até com "homens de negócios" estabelecidos em outras capitanias. $^{454}$

Outros indícios encontrados na documentação também apontam para a existência de uma rede social construída por Pedroso impregnada por indivíduos ligados à elite local e mesmo de outras partes da colônia. Sabe-se que, por algumas vezes, Pedroso serviu como procurador de outras pessoas. Com o crescimento da colonização, da dispersão do povoamento e com o progresso da dinâmica comercial, a ampliação das redes de contatos se fazia cada vez mais necessária para a manutenção dos negócios e de assuntos gerais, e com a dificuldade de locomoção ainda em alta no Brasil de então, o instrumento da "procuração" era muito útil. Nesse sentido, eram extremamente comuns os registros de procuração onde se dava ao outorgado os direitos de cobrar e receber dívidas de dinheiro, fazenda, rendimentos, mercadorias, encomendas, carregações, escravos, além de muitas outras atribuições as quais o procurador nomeado se responsabilizava em cumprir. Assim, acredita-se que a escolha dos indivíduos para tal função não era aleatória, visto que estes lidavam com assuntos importantes em nome dos outorgantes como, por exemplo, em transações econômicas. Ao contrário, a escolha de um procurador deveria ser feita, preferencialmente, a um conhecido, um parente ou mesmo após a indicação de algum conhecido, mas que inspirasse capacidade e, principalmente, confiança. Normalmente, como é de se supor, a tendência era optar por membros da elite local, já envolvida nos negócios políticos e ajustada aos trâmites burocráticos locais, além do que carregava em si certa carga de influência sobre a população, sem falar no poder de mando. Enfim, nomear um membro da elite local era, de fato, a escolha mais apropriada.

Através dos Livros de Registros constatou-se que Carlos Pedroso serviu como procurador em seis ocasiões, sem mencionar nas vezes em que exerceu tal função a serviço da Câmara da vila de Taubaté ${ }^{455}$, da Coroa e da Fazenda Real. ${ }^{456}$ Entre os anos de 1698 e 1702, Pedroso representou juridicamente algumas pessoas, homens e mulheres, habitantes

\footnotetext{
${ }^{454}$ Cf. Livro de Registros e Escrituras Cx: 157 (1676-1700) e Cx: 158 (1700-1711). A.H.M.T.

455 Cf. "Parecer do Capitão-mor Carlos Pedroso da Silveira...". AHU - Conselho Ultramarino Brasil/Rio de Janeiro. Cx. 7, doc. 741. p. 7.

${ }^{456}$ Cf. FRANCO, Francisco de Assis Carvalho. Op. cit. p. 381.
} 
da própria vila e de outras localidades como Rio de Janeiro e "cidade da Bahia". 457 Levando em consideração tais vezes em que foi acionado como procurador, é lícito considerá-lo como um homem de prestígio, confiança e, sobretudo, com capacidade de se articular entre a sociedade local a fim de cumprir com os objetivos propostos na tarefa por ele assumida quando aceitou ser representante legal de outra pessoa.

Coincidentemente, as atividades de Pedroso como procurador começaram em fins do século XVII, período em que ele se consagrava como homem de destaque entre a população e mesmo entre os membros da própria elite local devido a suas atuações em diferentes cargos governamentais, militares e, principalmente, sua participação direta nos acontecimentos que envolveram as descobertas oficiais de ouro nas Minas Gerais e a posterior entrega das amostras do metal para Sebastião de Castro Caldas, governador do Rio de Janeiro. Este último fato, como se verá mais adiante, favoreceu enormemente Pedroso em sua jornada em direção a maiores cargos e ampliação do se reconhecimento perante as autoridades reais, situação que muitos vassalos, senão todos, aspiravam alcançar. Prestígio, poder, riqueza e status, eis os objetivos a serem atingidos.

Desde o momento em que Pedroso se instalou em Taubaté, seus interesses aí se enraizaram. Logo de imediato, envolveu-se com o grupo dominante local uma vez que esteve no exercício do cargo de Sargento-mor para o qual foi designado ainda no início da década de 1690. Daí por diante, não parou mais de atuar na vida pública da vila e da região.

Em documento datado de 20 de maio de 1700, Antonio de Barros Freire, Antonio Velho Cabral, Domingos Cordeiro, Francisco Alves Correa e Manuel Garcia Velho, como oficiais da Câmara de Taubaté certificam que Carlos Pedroso "é um dos homens republicanos" da dita vila "por haver servido de Juiz Ordinário e almotacél várias vezes". 458 Inteiramente associado ao núcleo de poder local, Pedroso, certo da consolidação de seu status entre a sociedade em que vivia, galgou maiores postos após a descoberta oficial das minas de ouro.

Como sabido, a participação direta da vila de Taubaté nos acontecimentos que antecederam as descobertas de ouro nas Gerais através do envolvimento de muitos de seus habitantes e, além disso, da sua localização geográfica que a inseriu na principal rota que

${ }^{457}$ Cf. Livro de Registros e Escrituras Cx: 157 (1676-1700) e Cx: 158 (1700-1711). A.H.M.T.

458 "Parecer do Capitão-mor Carlos Pedroso da Silveira...". AHU - Conselho Ultramarino Brasil/Rio de Janeiro. Cx. 7, doc. 741. p. 7. 
levava aos sertões mineiros e, por isso mesmo, parada obrigatória dos viajantes, teve peso considerável na decisão tomada pelas autoridades de nela instalar uma casa de fundição destinada ao comprimento da prática tributária que vigorava no período, a extração do quinto, isto é, o recolhimento de $20 \%$ do metal como imposto. ${ }^{459}$ Com o objetivo de impedir os descaminhos do ouro e aumentar a vigilância sobre os paulistas "tidos secularmente por notórios descaminhadores (...) a oficina de Taubaté revelou-se a mais importante dentre as demais, posto que 'nela confluía o aluvião do ouro das minas dos Cataguases, ao passo que as outras, estabelecidas nas vilas de São Paulo e Paranaguá, apenas quintavam a pequena produção do ouro de lavagem'."460

Assim, devido à importância do funcionamento da casa de Fundição, era de se esperar que fosse nomeado para o cargo de Provedor da dita oficina alguém de extrema confiança e responsabilidade. Não apenas como uma maneira de retribuir os serviços prestados nos momentos cruciais das notícias do achamento de ouro, ${ }^{461}$ a nomeação de Carlos Pedroso para a função de Provedor se deu por ser de conhecimento de todos que "nos cargos que exerceu o seu procedimento foi sempre o mais correto e exemplar". ${ }^{462}$ Por estar inserido no cotidiano local, ciente das práticas de seus habitantes, envolvido nos negócios em torno do ouro, nada mais apropriado e estratégico do que a indicação de Pedroso para tal cargo. Enfim, um vassalo à altura do posto.

Sabe-se que, de 1695 a 1705, foi Pedroso, então, responsável pela captação dos impostos que recaíam sobre a exploração do ouro. Vale lembrar que sua jurisdição não se restringia apenas à vila de Taubaté, também exercia a função na oficina de Guaratinguetá e

\footnotetext{
459 Ao contrário do que pensam alguns autores que defendem a instalação da casa de fundição em Taubaté como prêmio dado aos seus habitantes pelo empenho nas descobertas do ouro - como poderia ser a presença física de uma instituição destinada a cobrança de impostos ser um prêmio? Adriana Romeiro salienta que "a opção por Taubaté para a instalação de uma casa de fundição além da de Parati, Guaratinguetá, São Paulo e Rio de Janeiro - também revelava a disposição de manter a região mineradora sob influência de São Paulo e Rio de Janeiro, uma vez que a vila se localizava na confluência do caminho velho do Rio e do caminho dos paulistas. Garantia-se - ao menos em princípio - que o fluxo populacional saído das Minas em direção às vilas litorâneas passasse obrigatoriamente pela Vila de Taubaté." ROMEIRO, Adriana. Paulistas e Emboabas no Coração das Minas: idéias, práticas e imaginário político no século XVIII. Belo Horizonte: Editora UFMG, 2008. p. 61. Cf. TOLEDO, Francisco de Paula. História do Município de Taubaté. 2a. Ed. Prefeitura Municipal de Taubaté, 1976. p. 15; ORTIZ, José Bernardo. São Francisco das Chagas de Taubaté. Tomo II. Taubaté: Prefeitura Municipal de Taubaté, 1996. p. 47.

${ }^{460}$ ROMEIRO, Adriana. Op. cit. p. 66-67.

${ }^{461}$ Tais fatos serão expostos em detalhes mais adiante.

${ }^{462}$ VASCONCELOS, Diogo de. Op. cit. p. 208.
} 
depois na de Parati, local para onde fora transferido unicamente porque não havia sido possível o transporte do maquinário que deveria ser levado até Taubaté, mas que, com as dificuldades em vencer a Serra do Mar com pesadíssimo material, forçou as autoridades em montar a ofina nesta vila litorânea. ${ }^{463}$

Nesse ínterim, em 23 de maio de 1699, recebeu de Artur de Sá e Menezes, governador da Repartição do Sul, a patente de capitão-mor regente da Capitania de Itanhaém, cargo que exerceu até o ano de $1702 .{ }^{464}$ Consta nesta carta patente que a preferência por Carlos Pedroso de seu porque "este se prova em pessoa capaz e de merecimentos para o dito posto" ${ }^{\text {465 }}$, além de já ter servido a Sua Majestade em outros cargos como o de ouvidor da mesma capitania, o de sargento-mor da vila de Taubaté e o de provedor da oficina real, também na dita vila. Alguns anos depois, entre 1705 e 1706, foi novamente nomeado para o posto de Capitão-mor "por haver já servido este mesmo Posto com bom procedimento e zelo do serviço de S. Majestade."466

463 Cf. "Carta régia ao governador da Capitania do Rio de Janeiro mandando que se conservasse a casa dos quintos de Taubaté, que tornasse para o Rio de Janeiro a casa da Moeda então em Pernambuco e dispondo outras providências sobre a fabricação da moeda, registro do ouro e pagamento dos quintos, de 31 de janeiro de 1702"; "Carta régia a Arthur de Sá e Menezes sobre o engenho de cunho destinado a oficina de Taubaté, de 6 de fevereiro de 1702"; "Carta de D. Alvaro da Silveira e Albuquerque a Miguel Telles da Costa, capitão-mor de Paraty, mandando-lhe por alli arrecadação o cunho, que, por dificuldade de condução, não pode chegar a Taubaté, de 23 de dezembro de 1702"; "Carta de D. Alvaro da Silveira de Albuquerque ao rei sobre a impossibilidade de fazer chegar até Taubaté o cunho destinado a oficina dos quintos da referida vila, de 20 de agosto de 1703"; "Carta de D. Alvaro da Silveira de Albuquerque a Carlos Pedroso da Silveira, provedor da casa de quintos da villa de Taubaté, comunicando-lhe a resolução régia de só haver oficinas em Santos e Paraty ordenando-lhe se removesse, com todos os seus oficiais para a ultima das citadas localidades, de 26 de junho de 1704"; "Carta de D. Alvaro da Silveira de Albuquerque aos oficiais da Câmara de Paraty sobre a casa de quintos que se ia estabelecer naquela villa e sobre providencias relativas aos descaminhos do ouro, de 31 de agosto de 1704"; "Carta de D. Alvaro da Silveira de Albuquerque a Carlos Pedroso da Silveira, provedor dos quintos da villa de Paraty, ordenando-lhe se apressasse em fazer a instalação do dito estabelecimento, de 2 de dezembro de 1704". In: Documentos Interessantes para a História e Costume de São Paulo. Publicação Oficial: Arquivo do Estado de São Paulo; São Paulo: Estabelecimento Gráfico Irmãos Ferraz, 1930. Vol. LI. p. 66, 67, 146, 199, 200, 249, 256, 257, 266 e 267, respectivamente.

464 "Patente de capitão da Capitania de N. S. da Conceição de Itanhaem, dada a Carlos Pedroso da Silveira por Artur de Sá e Menezes - de 23 de maio de 1699”. In: R.I.H.G.S.P. Volume XVIII, 1913. São Paulo: Typographia do Diário Oficial, 1914. p. 373-374.

${ }^{465}$ Idem, Ibidem. p. 269.

466 "Patente de Capitão-mor da Capitania de N. S. da Conceição de Itanhaém a Carlos Pedroso da Silveira, dada por D. Fernando Martins Mascarenhas de Lancastro, de 5 de outubro de 1705." In: Documentos Interessantes para a História e Costume de São Paulo. Publicação Oficial: Arquivo do Estado de São Paulo; São Paulo: Estabelecimento Gráfico Irmãos Ferraz, 1930. Vol. LI. p. 310-311. 
Os anos seguintes não denunciam nenhum outro tipo de participação oficial de Pedroso em qualquer posto ou cargo. Será apenas na primeira metade da década de 1710 que voltará a ocupar algum ofício dentro do quadro administrativo colonial. Diogo de Vasconcelos registra em sua obra que Dom Brás Baltazar da Silveira, Governador da Capitania de São Paulo e Minas, concedeu a Pedroso a patente de Mestre de Campo e Capitão-mor regente das vilas de Taubaté, Guaratinguetá e Pindamonhangaba. ${ }^{467}$ A veracidade da informação pode ser confirmada através do seu inventário, datado de 18 de agosto de 1719, visto que ainda ocupava o posto quando de sua morte. ${ }^{468}$

Em síntese, a vida de Carlos Pedroso da Silveira oscilou entre dois pólos, o local e o metropolitano. Como foi visto até aqui, suas atividades econômicas, suas relações sociais e políticas estiveram extremamente ligadas ao grupo dominante existente na vila de Taubaté, fazendo com que, de fato, seus interesses também estivessem enraizados no âmbito local, ajustando-se, em princípio, as tendências controladas pela elite aí estabelecida no que diz respeito à dinâmica produtiva e administrativa. Assim, foi possível encontrar um indivíduo envolvido nas entradas sertanistas, com posse de índios escravizados "ilegalmente", participante dos negócios em torno dos empréstimos, inclusive de ouro, produtor agrário, principalmente de cana-de-açúcar, e também fabricante de telhas. Pessoa respeitada pelos cargos ocupados e procurada pela capacidade de influência e pelo entendimento burocrático que poucos detinham. Portanto, era um homem inserido e aliado à elite local taubateana.

Por outro lado, Pedroso também se posicionava a favor dos interesses da Coroa, comportando-se como um fiel vassalo no exercício de cargos oficiais tanto políticos como militares que eram fundamentais para a manutenção do processo colonizatório português no Brasil. Como foi observado, ele não apenas fez parte do seleto grupo que detinha em suas mãos o controle da governança local, mas também alçou maiores vôos, chegando a ocupar postos de maior envergadura. Embora o acesso à elite local fosse algo restrito a uma

\footnotetext{
${ }^{467}$ VASCONCELOS, Diogo de. Op. cit. p. 208.

${ }^{468}$ Inventário de Carlos Pedroso da Silveira (1719). Cx: 1716-1719. Arquivo Histórico Municipal de Taubaté. O testamento encontra-se anexado ao documento. Vale mencionar que alguns autores divergem quanto a data da morte de Pedroso. Carvalho Franco acredita ter sido em 17 de agosto de 1718, Carlos da Silveira por sua vez defende que tenha sido em 7 de agosto de 1719 e Vasconcelos tem como opinião a data de 17 de agosto de 1720. Considerando que o testamento de Pedroso data de 15 de agosto de 1719 e o seu inventário de 18 de agosto do mesmo ano, obviamente que sua morte se deu entre esses dias. Cf. FRANCO, Francisco de Assis Carvalho. Op. cit. p. 381; SILVEIRA, Carlos da. Op. cit. p. 49; VASCONCELOS, Diogo de. Op. cit. p. 209.
} 
pequena parcela da sociedade, sabe-se que isso era mais viável e estava ao alcance das pessoas, ou seja, o ingresso na elite local podia ser difícil, porém havia condições reais presentes no cotidiano que davam oportunidades que capacitavam os indivíduos para uma futura inserção no grupo. Se o objetivo fosse alcançar outras esferas do poder, a dificuldade aumentava em muito. Numa situação como essa, a origem familiar, as relações sociais de maior amplitude, o comportamento e a prestatividade eram quesitos que julgavam a capacidade das pessoas para o ingresso no quadro administrativo colonial que lidava com poderes mais elevados. Pouquíssimos conseguiram o que Pedroso obteve. Este soube aproveitar a conjuntura e, dessa maneira, ganhou a confiança das autoridades metropolitanas, mas isso acarretou no alinhamento de seus interesses aos do poder oficial frente ao dos colonos, o que lhe custou, como se verá, muito caro.

\subsection{Oportunismo do ouro e ascenção social}

Como foi observado no primeiro capítulo desta dissertação, a Coroa portuguesa se utilizou amplamente da oferta de honras, prêmios e títulos nobiliárquicos como recompensa destinada aqueles que se destacavam pelas atitudes que não apenas contribuíam para o progresso do próprio reino como também da monarquia em si. Na verdade, tal premiação era algo previamente estabelecido já que se tratava de uma prática comum levada a cabo por um Estado Patrimonialista, e significava, nada mais e nada menos, do que o reconhecimento oficial da figura idealizada de um "bom vassalo" ou daquilo que se esperava de um súdito em determinados momentos da história de Portugal.

Supõe-se que bons vassalos deviam existir muitos, mas relativamente poucos receberam algum tipo de agradecimento. No Brasil, em especial, devido à distância em relação à corte e aos olhos das autoridades metropolitanas, era natural que o reconhecimento fosse bastante difícil, salvo períodos de maior importância, isto é, houve etapas da colonização lusitana na América que foram propícias tanto à distribuição de prêmios como ao destaque de certos colonos. ${ }^{469}$ Assim, não obstante as dificuldades de contato entre membros de diferentes níveis sociais, neste caso um vassalo comum e o grupo

\footnotetext{
${ }^{469}$ Pode-se citar, por exemplo, a guerra entre portugueses e holandeses no processo de restauração de Pernambuco. Nesta ocasição, prêmios foram prometidos e concedidos àqueles que se destacaram. Cf. MELLO, Evaldo Cabral de. Rubro Veio: o imaginário da Restauração Pernanbucana. Rio de Janeiro: Nova Fronteira, 1986.
} 
governante da colônia, momentos como em guerras, conflitos, lutas políticas, levantes e revoltas serviram positivamente para a aproximação entre eles, visto que ambos faziam parte de um todo e este todo, em determinado momento, resumia-se à manutenção e à estabilidade do processo de dominação colonial no Brasil. Nesse sentido, colonos desconhecidos tinham oportunidades de reconhecimento e, através delas, mudar rapidamente o posicionamento social frente ao restante da população.

Desde muito cedo, ainda nas primeiras décadas da colonização do Brasil, as expedições sertanistas serviram como meio para a aquisição de símbolos de distinção. Num vasto território, descoberto havia pouco tempo, extensamente povoado por tribos indígenas, muitas delas hostis aos colonizadores, a única forma eficaz para a efetivação da exploração colonial, de imediato, foi a instalação da povoação na faixa litorânea. Não obstante as precauções tomadas no sentido de manter o mínimo possível de segurança em terras ainda sem controle, muitas investidas violentas de indígenas afetaram o desenvolvimento da empresa colonial. Logo, cada vez mais se fazia necessária a organização de expedições imbuídas de caráter militar a fim de combater os índios que ofereciam perigo aos colonos. A guerra contra os silvícolas foi uma constante durante todo o período colonial do Brasil, e em muitas destas ocasiões, sendo oficializadas ou não, seus participantes estiveram a serviço do rei visto que promoviam a ampliação da exploração portuguesa, seja na expansão e no reconhecimento de novas áreas, seja na aquisição de mão-de-obra escrava para o funcionamento da incipiente máquina produtiva. Então, não é de se estranhar os requerimentos feitos por sertanistas junto às autoridades metropolitanas solicitando prêmios em troca dos serviços prestados. ${ }^{470}$

Além dos conflitos entre colonizadores e índios, as expedições de prospecção eram alvo de largo interesse. Por quase dois séculos, já que a descoberta oficial das minas de ouro só ocorreu na última década do século XVII, as Coroa ibéricas e os colonos no Brasil conviveram com constantes notícias, boatos e até lendas referentes à existência de metais e

\footnotetext{
470 "Vários foram os bandeirantes paulistas que, após a conquista de exntesas áreas no Nordeste, se viram envolvidos durante anos em demandas judiciais, tentando obter das autoridades coloniais os prêmios que lhes haviam sido prometidos quando seu trabalho fora solicitado." VOLPATO, Luiza Rios Ricci. Entradas e Bandeiras. São Paulo: Global, 1985. p. 49.
} 
pedras nobres no interior da colônia. ${ }^{471}$ Assim, muitas expedições sertanistas foram organizadas, tanto pelo poder oficial como pelo poder privado, com o objetivo de averiguar tais informações. A Coroa, maior interessada no assunto, máxime a da dinastia dos Bragança, sempre incentivou, salvo alguns pequenos períodos regidos por uma política de não dispersão, a penetração de homens no sertão a fim de descobrir as tão sonhadas minas de ouro, de prata e de pedras preciosas, e, por isso mesmo, não foram poucas as situações em que eram formalizadas as ofertas de prêmios e mercês àqueles que se destacassem em tais empreitadas. Enfim, o sertanismo definitivamente fazia parte do jogo de relações entre Coroa e vassalos, cada qual defendendo seus respectivos interesses.

Ao tempo de Carlos Pedroso da Silveira, muita coisa havia se passado. Muitas pesquisas de prospecção foram desenganadas, diversos atritos entre colonos, jesuítas e governo ocorreram em torno da ilegalidade do cativeiro indígena, contratos foram estabelecidos visando a destruição de tribos de índios e quilombos, além de guerras contra estrangeiros (holandeses, franceses e espanhóis). Em todos esses momentos, o sertanismo e a atuação dos colonos em proveito da própria Coroa foram extremamente úteis para o desenvolvimento da colonização no Brasil. Muitos vassalos conseguiram o reconhecimento de suas ações e, por isso mesmo, alcançaram maior status social, pois lhes foram entregues patentes militares, cargos administrativos, hábitos das ordens militares, pagamento de tenças e mercês. Enfim, a negociação entre vassalos e Coroa era uma situação possível e fazia parte da realidade, e as oportunidades para tal aguçavam os interesses de ambos os lados.

De fato, os homens do período colonial sabiam que havia chances de se promoverem socialmente, mesmo que essas chances fossem mínimas. O estabelecimento de contratos que firmavam a prestação de serviços em troca de símbolos nobilitadores era uma prática comum no mundo do Antigo Regime. Os paulistas, por exemplo, se destacaram nesse “jogo de favores”. Assegura Adriana Romeiro que eles inauguraram uma tradição

\footnotetext{
${ }^{471}$ Sobre as lendas em torno das minas de metais e pedras nobres. Cf. HOLANDA, Sérgio Buarque de. Visão do Paraíso: os motivos edênicos no descobrimento e colonização do Brasil. $6^{\text {a }}$. São Paulo: Brasiliense, 1994.
} 
política firmada entre Coroa e vassalos baseada numa conotação contratualista, além de fazerem da noção de direito de conquista um instrumento de reivindicação. ${ }^{472}$

O envolvimento de Carlos Pedroso nas expedições sertanistas se fez num período em que o apresamento de índios e a procura por metais nobres quase que se confundiam. É difícil estabelecer uma divisão correta entre os dois objetivos, mesmo porque, uma vez no sertão, as expedições visavam primeiramente a conquista de riquezas, sejam elas humanas ou materiais.

Sabe-se que Pedroso foi "companheiro do sertanista Bartolomeu Bueno de Siqueira, desde 1683, em que João Lopes de Lima, como cabo, Francisco Rodrigues, Antonio Vaz, Manuel Rodrigues de Arzão, Antonio Domingues Galera, Manuel Ferreira de Lemos e outros, andavam em sondagens pelo sertão dos Cataguazes." ${ }^{\text {473 }}$ Ou apresando mão-de-obra indígena, ou procurando minas de ouro, o que interessa é que Pedroso esteve ligado a muitos sertanistas de prol e com eles obteve experiência no assunto, inclusive nas práticas de dentro e de fora das expedições.

Apesar de se ter conhecimento sobre a participação de Pedroso no movimento sertanista, sabe-se apenas pouquíssimos detalhes sobre tais episódios. Mesmo a maior de suas façanhas, qual seja, o anúncio oficial da descoberta das minas de ouro, é motivo de discussões entre os autores, gerando, até hoje, controvérsias.

A versão mais contada, e talvez por isso mesmo a mais aceita, é a que relata Diogo de Vasconcelos em sua importante obra História Antiga das Minas Gerais. Resumidamente, para ele assim tudo ocorreu:

Antes de expirar, Antonio Rodrigues Arzão chamou por Bartolomeu Bueno de Siqueira, eram cunhados, e, confiando-lhe o segredo das minas, o concitou a prosseguuir nos descobrimentos, sobre os quais lhe deu as necessárias instruções. (...) Alvoroçado, consequentemente, pelo que ouvira do moribundo, seu amigo, aprestou-se, em princípios de 94, e foi ter-se em Taubaté com os parentes, que o receberam de braços abertos, contando com a sua capacidade para o desenlace da empresa. ${ }^{474}$

\footnotetext{
472 "Para os homens do Planalto, a retribuição pouco tinha a ver com a magnanimidade, excluindo, assim, o caráter de graça de que se revestiam as mercês régias; ao contrário, a retribuição adquiria um sentido de obrigatoriedade, muito semelhante à noção de contrato, em que os serviços e as recompensas eram primeiramente negociados por meio de procuradores enviados diretamente a Lisboa." ROMEIRO, Adriana. Paulistas e Emboabas no Coração das Minas: idéias, práticas e imaginário político no século XVIII. Belo Horizonte: Editora UFMG, 2008. p. 239.

${ }^{473}$ FRANCO, Francisco de Assis Carvalho. Op. cit. p. 381.

${ }^{474}$ VASCONCELOS, Diogo de. Op. cit. p. 149
} 
No entanto, como foi mostrado no capítulo anterior, a montagem de uma expedição não era coisa que se fazia de um dia para o outro, pois inevitavelmente acarretava na conglomeração de materiais necessários para a viagem e de homens de confiança a fim de participar da empreitada. E nem sempre se tinha ao alcance das mãos os recursos suficientes, não pelo menos a todos os envolvidos, o que era muito comum. Ocorreu que "os bandeirantes empenhados no cometimento, sendo mais ou menos abastados, dispunham de meios e equipavam as suas tropas sem exigirem dos amigos grandes desembolsos", porém "Bueno lhe apareceu de mãos vazias, nada podendo empreender sem que primeiro lhe adiantassem o necessário." ${ }^{475}$ É neste momento que surge a figura de Carlos Pedroso da Silveira, "o mais rico dos associados, fornecendo-lhe pronta e bem municiada a leva que devia conduzir." ${ }^{476}$ A esta, juntou-se o Capitão Miguel Garcia de Almeida e Cunha que se apresentou com sua tropa e armas organizadas à sua própria custa a fim de se reunir ao chefe da expedição na condição de ajudante, e assim se firmou. "Feitos os preparativos, a expedição partiu para a Itaverava em abril de 1694." ${ }^{477}$

Antes de dar prosseguimento ao relato, é preciso registrar que as dúvidas dos estudiosos já começam com a participação ou não de Pedroso na expedição, ou melhor, com a maneira como ela se deu. Se para Diogo de Vasconcelos e Francisco de Assis Carvalho Franco o envolvimento de Pedroso não passou do custeio da dita bandeira, Afonso de E. Taunay preferiu se abster dessa opinião, isto é, para ele ainda "não se apurou se acompanhava a Bartolomeu Bueno de Siqueira ou se sua atuação se limitou a segui-lo na viagem ao Rio de Janeiro quando apresentaram a Castro Caldas as primeiras amostras do descobrimento", fato atestado primeiramente por Pedro Taques, e que se verá em detalhes mais adiante. $^{478}$

\footnotetext{
${ }^{475}$ Idem, Ibidem. p. 149.

${ }^{476}$ Idem, Ibidem. p. 150.

${ }^{477}$ Idem, Ibidem. p. 150.

${ }^{478}$ Cf. VASCONCELOS, Diogo de. Op. cit. p. 150; FRANCO, Francisco de Assis Carvalho. Op. cit. 381; TAUNAY, Affonso de E. História das Bandeiras Paulistas. São Paulo: Edições Melhoramentos, Tomo I, $2^{a}$ Edição, 1961. p. 216; LEME, Pedro Taques de Almeida Paes. História da Capitania de S. Vicente. São Paulo: Ed. Melhoramentos, s/d. p. 151-152; LEME, Pedro Taques de Almeida Paes. Notícias das Minas de São Paulo e dos Sertões da mesma Capitania. São Paulo: Livraria Martins Editora, 1976. p. 83.
} 
Voltando aos acontecimentos, estando já no sertão de Itaverava a comitiva de Bartolomeu Bueno, chegou posteriomente o "Coronel Salvador Fernandes Furtado de Mendonça, conduzindo uma nova coluna, que saiu de Taubaté em princípios de 1695 com vista de socorrer as expedições antecedentes e de auxiliar o descobrimento, caso não estivesse já realizado." E por ter partido do povoado depois de Bueno "trazia o Coronel armas novas, bem assim uma espingarda e uma catana de feitio moderno, que invitaram a inveja de todos." ${ }^{479}$ A maior atenção foi despertada em Miguel Garcia que, "de volta do ribeirão aurífero, deparou com a nova comitiva, e o mesmo foi ver as armas, que desejálas.” Assim, propôs ao Coronel Salvador uma troca: daria suas armas pelas deste mais todo o ouro que haviam encontrado, algo em torno de 12 oitavas. Dessa maneira, aceitou o dito Coronel a proposta.

No entanto, continua a narração de Vasconcelos:

passados alguns dias, Bartolomeu Bueno, que se recolhia do Paraopeba, surgiu na Itaverava; mas o prazer da surpresa, vendo os amigos, desbotou-se ao saber da transação. Arguiu ele a Garcia que as bandeiras, sendo corpos coletivos, disciplinados, nem mesmo o chefe tinha poder para extrair o objeto, para o qual se associavam. Tinham vindo a descobrir ouro no sertão: o ouro pois que aparecesse, fosse qual fosse o seu inventor, pertencia a todos em comum; e naquele instante caso o abuso foi maior, porque se haviam obrigado a enviar as primícias da diligência a Carlos Pedroso. ${ }^{480}$

Os ânimos estavam exaltados. Miguel Garcia não aceitava a posição defendida por Bartolomeu Bueno, pois dizia que "andava no sertão à sua custa e própria conta, não a cargo de Carlos Pedroso, tanto mais que o compromisso com este tomado foi quanto ao ouro esperado no Tripuí, não ao que ele havia achado, sem o querer, em diligência mui distinta, procurando alimento para sua tropa."481 Percebendo, então, que um comum acordo entre os dois estava cada vez mais distante, o Coronel Salvador, de posse do disputado ouro, preferiu cedê-lo a fim de acabar com a discórdia, com a condição de que fosse levado por um terceiro até Carlos Pedroso. Assim foi feito, sendo o responsável por transportar o metal até Taubaté o Capitão Manuel Garcia de Almeida, irmão de Miguel Garcia.

\footnotetext{
${ }^{479}$ VASCONCELOS, Diogo de. Op. cit. p. 151.

${ }^{480}$ VASCONCELOS, Diogo de. Op. cit. p. 152.

${ }^{481}$ Idem, Ibidem. p. 152.
} 
Enfim, "chegando Garcia à vila, foi visitado por Pedroso, a quem minuciosamente informou da posição das bandeiras; e lhe entregou as amostras, que trouxera." ${ }^{482}$ Daí por diante, as ações de Pedroso são de largo conhecimento. Os autores são unânimes quanto a elas. Com o ouro em mãos, Pedroso partiu para o Rio de Janeiro em 1696 e manifestou oficialmente as amostras do metal ao Governador Sebastião de Castro Caldas que, por sua vez, as remeteu a El-Rei D. Pedro II juntamente com carta datada do dia 16 do mesmo ano dando detalhes sobre as descobertas feitas no "sertão de Taubaté" e tendo como responsáveis diretos Bartolomeu Bueno de Siqueira e Carlos Pedroso da Silveira. ${ }^{483}$

Logo, qualquer que tenha sido a maneira como Pedroso se envolveu nas bandeiras que acabaram por extrair as famosas 12 oitavas de ouro, coube a ele, diz Basílio de Magalhães, o anuncio oficial da descoberta. ${ }^{484}$ E por ter sido o responsável por isso, obteve de Sebastião de Castro o cargo de Provedor dos Quintos e Administrador da Fundição que se ordenara instalar em Taubaté.

Até então, Pedroso se encontrava entre os membros de uma elite local ocupando cargos administrativos e militares, o que lhe conferia respeito e credibilidade. No entanto, o seu poder atingia, no máximo, proporções regionais. Caso quisesse ampliá-lo, era preciso subir nos níveis hierárquicos do quadro administrativo colonial, o que, sem dúvida, era muito restrito. Ao que tudo indica, as atitudes de Pedroso quanto a participação e, principalmente, a entrega das amostras de ouro ao governador revelam o seu interesse em ser reconhecido como fiel vassalo perante os representantes diretos do poder monárquico e, como não podia deixar de ser, como merecedor de honras e prêmios, o que, afinal, lhe daria maior distinção. De fato, deu certo. O cargo que passou a ocupar na Casa de Fundição de Taubaté era de extrema importância visto que se tornou responsável pela captação dos

${ }^{482}$ Idem, Ibidem. p. 152. Em um documento de autoria desconhecida está registrado que, na verdade, teria chegado a Taubaté Manuel Garcia Velho, e "aí o foi visitar Carlos Pedroso da Silveira, e porque era abundante de habilidade e engenho para se conciliar com os patrícios, houve assim as doze oitavas de ouro." A ênfase na "habilidade e engenho" de Pedroso denota que a aquisição do ouro se deu não por um acordo previamente estabelecido e sim por um negócio estabelecido no momento da tal visita. Cf. "Descrição Geographica, topographica, historica e politica da Capitania das Minas Geraes seu descobrimento, estado civil, politico e das rendas reaes." In: R.I.H.G.B. Tomo LXXI. Rio de Janeiro: Typographia Universal de Laemmert, 1909. p. 123.

${ }^{483}$ TAUNAY, Afonso de E. Op. cit. p. 215.

${ }^{484}$ MAGALHÃES, Basílio de. "O Bandeirismo no Brasil: subsídios para o estudo deste importante fenômeno da nossa evolução." In: R.I.H.G.B. Tomo LXXVII. Rio de Janeiro: Typographia Universal de Laemmert, 1915. p. 80. 
impostos taxados sobre a exploração aurífera e o combate aos infratores. A sua posição, naquele momento de início das investidas na produção de ouro, ganhou lugar entre as principais preocupações do mundo colonial português.

Se aos olhos das autoridades oficiais Pedroso foi merecedor das honras recebidas, houve quem denunciasse apenas o seu oportunismo,

posto que Antonio Rodrigues Arzão denunciasse primeiro que Carlos Pedroso da Silveira as três oitavas de ouro que descobriu nas Minas Gerais, a sua morte impediu o progresso desta denunciação, e ficou Carlos Pedroso conseguindo a glória de apresentar o ouro que ele não descobrira. ${ }^{485}$

Estas palavras proferidas por Cláudio Manuel da Costa, poeta do século XVIII, podem até ser verdadeiras. Mas o fato é que Pedroso soube muito bem jogar de acordo com as regras estipuladas pela cultura política do Antigo Regime em vigor desde os princípios da colonização do Brasil. Visando a defesa de interesses particulares, mostrou-se habilidoso no relacionamento entre os dois pólos de poder existentes na colônia: o poder local e o poder metropolitano. A oferta de vantagens dentro do quadro social, político e econômico animavam os colonos na prestação de serviços em prol dos objetivos traçados pela Coroa, e Pedroso foi apenas mais um que se aventurou neste tipo de jogada.

O seu sucesso foi imediato. Aumento de poder, reconhecimento, ascensão social, etc. Entretanto, tudo tem os seus limites e, como se verá a seguir, realmente teve.

\subsection{Limites, frustração e morte}

A prestação de serviços era um exercício prático da condição de vassalagem. Enquanto a maioria da população a praticava apenas no seu comportamento social esperado, isto é, agindo dentro do enquadramento moldado pelas leis, outros ultrapassavam as expectativas oficiais e se aprofundavam colaborando para a boa organização e funcionamento da máquina governamental na colônia. Estes passavam a ser muito úteis à própria Coroa, e por isso mesmo eram cooptados por ela. É nesse sentido que se busca compreender a lógica das recompensas. Seja uma patente militar, seja um cargo administrativo ou um símbolo de distinção, qualquer tipo de "prêmio" trazia o seu

${ }^{485}$ COSTA, Cláudio Manuel da. "Fundamento Histórico do Poema Vila Rica". In: Obras Poéticas. Rio de Janeiro: João Ribeiro, 1903. p. 157. 
beneficiário para o lado dos interesses governamentais. Foi justamente o que aconteceu com Carlos Pedroso.

Não contente com o que já conseguira, Pedroso procurou aumentar sua "qualidade social". Nesse sentido, avançou a sua relação para níveis ainda mais altos. A fim de adquirir um hábito de Cristo com tença e um posto de comando da primeira companhia de infantaria que estivesse vago no Rio de Janeiro, Pedroso precisou oficializar seu pedido e encaminhálo para a Corte, onde seria analisado. A sua aprovação não seria nada fácil posto que o que solicitava eram prêmios entregues somente a poucos favorecidos e, além do mais, a comprovação dos serviços prestados cabia ao próprio requerente o que significava, em um Império em constante evolução burocrática, a configuração de um rol de documentos que provassem seus atos, sendo portanto de vital importância a manutenção de uma boa relação social com membros da elite colonial, além da disponibilidade de tempo para viagens e, é claro, dinheiro para cubrir os gastos com as ditas viagens e com a confecção dos documentos.

Em aproximadamente dois anos, Pedroso colheu testemunhos de muitas pessoas em diferentes localidades e os anexou ao pedido oficial referente as mercês. O conteúdo de tal documentação que foi, de fato, encaminhado a Corte será exposto com o objetivo de melhor compreender a dinâmica do jogo de prestação de serviços e da premiação realizada entre a Coroa e seus vassalos. ${ }^{486}$

Datado de 28 de janeiro de 1701, a conclusão da análise foi apenas o capítulo final de uma trajetória que se iniciou formalmente ainda no ano de 1698. O esforço de Pedroso se concentrou em relatar tudo o que tinha feito em benefício da Coroa e, ao mesmo tempo, provar através do testemunho de muitas pessoas a veracidade dos fatos e, com isso, corroborar com maior número de informações para o seu merecimento quanto à premiação desejada. Somente após conseguir juntar as "provas" cabíveis ao processo, Pedroso enviou uma socilicitação ao próprio rei na qual pede permissão para ir ao reino tratar deste assunto, sendo-lhe positiva a resposta. ${ }^{487}$

\footnotetext{
${ }^{486}$ Toda a documentação que será utilizada encontra-se em "Parecer do Capitão-mor Carlos Pedroso da Silveira...”. AHU - Conselho Ultramarino - Brasil/Rio de Janeiro. Cx. 7, doc. 741.

${ }^{487}$ O conteúdo da resposta dada pelo Rei foi o seguinte: “Artur de Sá e Menezes. Amigo. Eu ElRey vos envio muito saudar. Carlos Pedroso da Silveira me representou aqui estar servindo com bom procedimento o oficio de Provedor dos quintos Reais da vila de Taubaté, e ter requerimentos nesta Corte que dependem da sua assistência, e pareceu-me ordenar-vos (como por esta o faço) que não
} 
O texto de abertura do documento, no tamanho exato de duas páginas, tem em seu conteúdo a descrição resumida das ações de Pedroso, inicialmente sustentada apenas sob o seu próprio ponto de vista, para depois, em páginas seguintes também ser confirmada por muitas pessoas e autoridades coloniais.

Assim inicia o documento:

Diz Carlos Pedroso da Silveira filho de Francisco Pedroso, natural de S. Paulo, que pelas certidões, patentes e mais papeis que apresenta consta haver servido a V. Magestade nos distritos da Capitania do Rio de Janeiro nos postos de Sargento-mor da vila de São Francisco das Chagas de Taubaté, ouvidor e capitão-mor da Capitania de Nossa Senhora da Conceição de Itanhaém, e Provedor das Minas e Quintos Reais da oficina da vila de Taubaté. ${ }^{488}$

Após enumerar os postos ocupados ${ }^{489}$, postos estes que serão adiante confirmados através de "certidões, patentes e mais papéis", Pedroso passou a qualificar seu comportamento quando do cumprimento de suas funções. Como previsto, ele entende que agiu sempre "com boa satisfação em tudo o de que foi encarregado do serviço de V. Magestade" ${ }^{, 490}$, principalmente a partir da década de 1690 quando teve participação ativa e direta do corpo administrativo colonial no Brasil.

Durante os dois anos e meio em que exerceu o posto de Sargento-mor da vila de Taubaté, contados a partir de 1692, atuou "com bom procedimento", e o mesmo também teria ocorrido quando foi Capitão-mor da Capitania de Nossa Senhora da Conceição de Itanhaém,

governando-a com todo zelo, tratando do bem comum da República, provendo os postos necessários para segurança das praças da dita capitania visitando-as com grande detrimento da sua pessoa e dispendio da sua fazenda, pela muita distancia em que ficam as vilas da sua jurisdição umas das outras. ${ }^{491}$

havendo inconveniente concedaes a Carlos Pedroso da Silveira Licença para poder vir para este Reino." Cf. "Carta Régia concedendo licença a Carlos Pedroso da Silveira, provedor dos quintos reais da vila de Taubaté, não havendo inconveniencia, para ir ao reino, afim de lá assistir a requerimentos seus - de 8 de novembro de 1699”. In: R.I.H.G.S.P. Volume XVIII. São Paulo: Typographia do Diário Oficial, 1914. p. 394.

488 "Parecer do Capitão-mor Carlos Pedroso da Silveira...". AHU - Conselho Ultramarino Brasil/Rio de Janeiro. Cx. 7, doc. 741.p. 01.

${ }^{489}$ Interessante notar que, num primeiro instante, Pedroso se preocupou em enumerar apenas os cargos de maior relevância, deixando em segundo plano aqueles de menor expressão, como os que exerceu na Câmara de Taubaté.

${ }^{490}$ Idem, Ibidem. p. 01.

${ }^{491}$ Idem, Ibidem. p. 01. 
A sua grande jogada, no entanto, ocorreu no ano de 1695, quando foi "por duas vezes da dita vila de Taubaté ao Rio de Janeiro a sua custa com as primeiras amostras dos

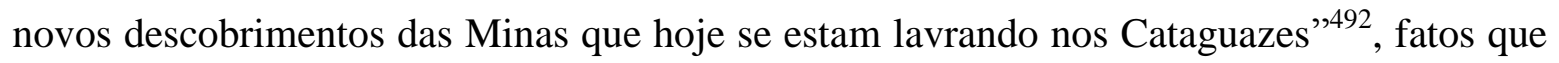
lhes deram como reconhecimento o cargo de Provedor das Minas de Taubaté, sendo responsável também pela captação dos Quintos Reais na oficina instalada na própria vila. No momento da feitura deste documento, ainda exercia tais funções "há mais de 4 anos com muito trabalho e zelo do aumento da fazenda Real pondo-lhe várias vezes em perigo de vida por obrigar algumas pessoas que não queriam trazer o ouro para se tirar o quinto que pertencia a V. Magestade."493

Considerava-se um vassalo exemplar - pode-se talvez usar aqui o termo "funcionário" -, pois prestava contas da "arrecadação" feita em sua oficina, além de emitir “ordens necessárias para a conservação dos mineiros", sempre agindo, como alega, em “serviço a V. Magestade seguindo todas as ordens que pelo Governador e Provedor da Fazenda Real do Rio de Janeiro lhe foram dadas."

Como Provedor dos Quintos, não se limitou a imprimir funções de caráter meramente administrativas. É possível encontrá-lo, em mais de uma ocasião, atuando em ocorrências criminais, sendo por isso responsável pela caçada e prisão de transgressores. O que, de fato, se deu quando Pedroso informou "ao dito Governador da notícia que tinha de que havia pessoa que fazia cunhos falsos para os por no ouro", e este lhe mandou "tirar devassa deste malefício, o que fez com todo o cuidado e deligência."495 Noutro caso, também ocorrido no ano de 1698, encarregou-se da prisão de "um religioso de S. Bento, por nome Fr. Roberto de Jesus por crimes que havia cometido contra a Lei de V. Magestade", e para tanto o perseguiu, indo "as vilas de Santos, S. Paulo e S. Vicente e a outras mais a sua custa e dispêndio considerável de sua fazenda pelas grandes distâncias que havia nas passagens de uma vila para outras em cuja diligência gastou dois meses."496

\footnotetext{
${ }^{492}$ Idem, Ibidem. p. 01.

${ }^{493}$ Idem, Ibidem. p. 01.

${ }^{494}$ Idem, Ibidem. p. 01.

${ }^{495}$ Idem, Ibidem. p. 01.

${ }^{496}$ Idem, Ibidem. p. 02.
} 
Porém, o esforço de Pedroso foi em vão já que enquanto um dos criminosos conseguiu fugir da cadeia, os outros não chegaram a ser capturados. ${ }^{497}$

Continuando a sua fala, menciona aquilo que, talvez, para ele seja o mais importante de seus atos depois da entrega oficial das amostras de ouro encontrado nas novas descobertas, é claro. No ano de 1699, o bom exercício de suas atribuições como gerente da casa dos quintos de Taubaté possibilitou com que fosse "ao Rio de Janeiro conduzir três arrobas, 13 arratéis e 6 onças de ouro tocante ao rendimento dos quintos da sua oficina". Ciente da grande responsabilidade levou consigo para guarda tanto dele como do ouro "18 homens pagos a sua custa, fretando para passagem deles e do dito ouro três embarcações por temer o encontro do Pirata que estava no tal tempo na Ilha Grande". ${ }^{498}$ Foi devido a este serviço que Pedroso recebeu formalmente o primeiro agradecimento Real através de uma carta datada de 19 de outubro do mesmo ano, "certificando-lhe que lhe ficava muito na lembrança para folgar de lhe fazer toda a mercê havendo tratasse de seus acrescentamentos." ${ }^{499}$ Situação semelhante teve lugar no ano seguinte (1700), quando

entregou da dita sua oficina da vila de Taubaté quatro arrobas, e 13 arrateis de seu rendimento que veio nesta frota embarcado para esta corte havendo-se em tudo com o procedimento que tem sido notorio a $\mathrm{V}$. Magestade e a seus Ministros de que V. Magestade lhe tornou a mandar agradecer este serviço por outra carta. ${ }^{500}$

\footnotetext{
${ }^{497}$ Em carta o Rei, Artur de Sá e Menezes diz que "mandei devassar na vila de Taubaté, e achou-se culpado a Domingos Dias de Torres na devassa de cunhos falsos, o qual mandei prender, porém emportou pouco esta diligência, porque minando a cadeia, limando os grades, fugiu, pela qual causa mandei logo ordem as justiças de todas as vilas para que o prendessem em qualquer parte que o achassem porque se não fizer um exemplar castigo nos delinquentes deste crime, será muito pernicioso exemplo para que possão continuar em cometê-lo V. Magestade neste particular mandará o que mais convier a seu Real serviço." Cf. "Carta de Arthur de Sá e Menezes ao Rei dando-lhe conta dos descaminhos dos quintos do ouro nas minas de S. Paulo, assim como das providências que ali tomou, vedando as quitas e cuidando de punir a Fr. Roberto e Domingos Dias Torres, fabricantes de cunhos falsos - de 22 de maio de 1698." In: R.I.H.G.S.P. Volume XVIII. São Paulo: Typographia do Diário Oficial, 1914. p. 337-338. Em outro documento, consta estar nas minas de Cataguases um dos fugitivos. Cf. "Carta de Arthur de Sá e Menezes ao Rei, dando-lhe conta das providências que tomara sobre o crime de cunhos falsos, do qual eram culpados o beneditino Frei Roberto e o Padre José Rodrigues Preto, vigário de Taubaté - de 4 de junho de 1698." In: R.I.H.G.S.P. Volume XVIII. São Paulo: Typographia do Diário Oficial, 1914. p.355. Interessante notar o grande envolvimento de clérigos neste tipo de crime.

498 "Parecer do Capitão-mor Carlos Pedroso da Silveira...". AHU - Conselho Ultramarino Brasil/Rio de Janeiro. Cx. 7, doc. 741.p. 02.

${ }^{499}$ Idem, Ibidem. p. 02.

${ }^{500}$ Idem, Ibidem. p. 02.
} 
O recebimento destas cartas, vindas diretamente do ponto mais alto de todo o Império português, ou seja, da própria figura do rei, significou para Pedroso o reconhecimento parcial de suas atitudes, e mais, a oportunidade concreta para a solicitação de mercês, isso explica a feitura do documento referente a tal pedido justamente no mesmo ano do recebimento da segunda carta, 1700.

Ao que se sabe, estas foram as únicas cartas mandadas para Pedroso. Apesar disso, Diogo de Vasconcelos afirma que "o Rei muitas vezes escreveu do próprio punho a Carlos Pedroso, a quem considerava amigo prestimoso." ${ }^{, 501}$ Estranhamente, este mesmo autor também relatou a existência de outra carta, datada de 16 de dezembro de 1696, "pela qual se comunica ter Sua Majestade concedido a Carlos Pedroso o hábito de Cristo." realmente isso se deu, por qual razão então Pedroso iniciaria um novo pedido de mercê do mesmo hábito, como denuncia o documento analisado aqui? Se verdade fosse, por que Pedroso não menciona a dita carta? Enquanto permanecem as dúvidas, o correto é continuar os estudos por meio das fontes que sobreviveram ao tempo, sendo impossível, então, cogitar sobre o que não se pode comprovar. Incertezas à parte deve-se prosseguir com a exposição do conteúdo documental focado neste capítulo.

Após relatar seus atos, Pedroso é considerado apto e merecedor do prêmio solicitado. Assim conclui o seu texto:

E portanto que dos serviços referidos nada tem havido satisfação alguma até o presente como consta da certidão de mercês de seu título, nem tem crime algum que lhe sirva de impedimento para lograr todas as que espera da Real Grandeza de V. Magestade e principalmente por um tão grande e tão extraordinário serviço que tem feito a $V$. Magestade na sua oficina de Taubaté em dois anos somente, pois dela tem resultado de utilidade a fazenda de V. Magestade perto de oito arrobas de ouro dos quintos de V. Magestade devendo-se a sua deligência o não se descaminhar cousa alguma, pelo notório zelo e cuidado com que se emprega em tudo o que toca ao serviço de V. Magestade e bem de sua Real fazenda. ${ }^{503}$

Como se pode notar, em termos jurídico-criminais e em termos de comportamento e vassalagem, Pedroso não tinha qualquer tipo de impedimento que pudesse barrar seu direito de solicitação da mercê. Enfim, estava transposta a primeira etapa.

${ }^{501}$ VASCONCELOS, Diogo de. Op. cit. p. 206.

${ }^{502}$ Idem, Ibidem. p. 165.

503 "Parecer do Capitão-mor Carlos Pedroso da Silveira...". AHU - Conselho Ultramarino Brasil/Rio de Janeiro. Cx. 7, doc. 741. p. 02. 
A fim de comprovar a sua situação e dar maior credibilidade a seu requerimento, as páginas seguintes do documento são formadas por 14 documentos anexados ao dito requerimento trazendo informações sobre o que afirmou o próprio Pedroso, apoiadas pelo testemunho de grande número de pessoas de diferentes níveis sociais, mas todos de suposta confiança visto que ocupavam postos administrativos na colônia. São elas: Antonio de Barros Freire, Antonio Velho Cabral, Domingos Cordeiro, Francisco Alves Correa e Manuel Garcia Velho - como oficiais da câmara da vila de Taubaté (1700); um tal de Frei Manoel do Rozário - como padre pregador na vila de Santos (1698); Estevão Lopes de Camargo - como juiz ordinário da câmara da vila de São Paulo (1698); Timóteo Correa de Goes - como Provedor e Contador da Fazenda Real das Capitanias de São Vicente e Nossa Senhora da Conceição de Itanhaém (1698); Artur de Sá e Menezes - como Governador e Capitão Geral do Rio de Janeiro, São Paulo e mais capitanias do Sul (1699-1700); Francisco de Brito Meirelles - como Provedor e Contador da Fazenda Real do Rio de Janeiro, Juiz da Alfândega, Direitos Reais e Meias Anatas Administrador Geral das Minas da Repartição do Sul (1695); Luiz Lopes Pegado - no mesmo posto que o anterior (1700); e Martim Garcia Lumbria - como Capitão-mor e Governador da Capitania de Itanhaém (1692). De maneira geral, todos visaram registrar as atitudes de Pedroso durante alguns anos de sua vida, especificamente aqueles em que se dedicou ao serviço Real. Enfatizaram, por último, que julgavam Pedroso "digno e merecedor de toda a honra e mercê que Sua Majestade for servido fazer-lhe." 504 Aqui termina a parte de Pedroso dentro do trâmite inicial do processo burocrático de seu pedido. Restava-lhe apenas esperar pela resposta.

Enquanto não se chegava a uma decisão final, Pedroso soube através do Fiscal Dr. Agostinho de Góis Ribeiro, um dos responsáveis por analisar seus documentos, que "posto ele suplicante juntava patente de Capitão-mor não tinha os anos que mandava o Regimento, nem era daqueles capitães que o mesmo Regimento dispensava para poderem requerer sem terem doze anos de serviço", ou seja, Pedroso não tinha cumprido os anos necessários para obter a mercê que desejava, fora isso, "no mais estavam os seus papéis correntes." 505

Entretanto, não conformado com a resposta, Pedroso recorreu a um novo parecer, desta vez de uma pessoa, infelizmente, não identificada, pois apenas rubricou o documento

\footnotetext{
${ }^{504}$ Idem, Ibidem. p.07, 11, 15, 19, 23, 25, 29, 33, 37, 41, 48 e 51.

${ }^{505}$ Cf. "Um documento referente a uma solicitação de Carlos Pedroso da Silveira". In: R.I.H.G.S.P. Volume LVII. São Paulo: Typographia do Diário Oficial, 1959. p. 629-630.
} 
com um "RRM". Esta também confirmou o que o dito Fiscal já havia concluído, mas levantou uma questão importantíssima e ao mesmo tempo complicada: para ele, "porquanto o serviço que ele suplicante tem feito a V. Magestade de até o presente é fora das regras ordinárias e digno de toda a remuneração por respeito da grande utilidade que da sua diligência, zelo e atividade tem resultado a Fazenda de V. Magestade" ${ }^{\text {506 }}$, referindo-se a captação dos quintos do ouro na oficina de Taubaté, não seria justo lhe conceder a mercê? Seus serviços foram qualificados como sendo "fora das regras ordinárias", dignos até mesmo do agradecimento Real via correspondência. O que, de fato, pesou na opinião desta pessoa foi, além dos bons serviços prestados por Pedroso, a promessa feita pelo rei nas cartas enviadas ao suplicante, onde dizia ficar "na lembrança este serviço para lhe fazer toda a mercê". Assim, "é a conveniência de terem efeito as reais promessas de V. Magestade de que pelas duas cartas lhe tem feito". Portanto, "para a V. Magestade que atentendo as razões referidas lhe faça mercê dispensar com ela na falta dos 12 anos de serviço, que é a dúvida do Fiscal, visto como no mais declarou estarem correntes para tratar de seu requerimento."

As coisas pareciam estar pendendo favoralmente para o lado de Pedroso. Apenas pareciam porque, logo depois, veio o desfecho do processo: o Conselho Ultramarino considerou inadequada a situação e concluiu que "por ora não há que deferir",508. Este despacho foi corroborado, definitivamente, pelo Fiscal Dr. Agostinho de Góis Ribeiro, finalizando, desta maneira, o processo de Pedroso ${ }^{509}$.

Após ter se ocupado por muito tempo e dispendido parte do seu dinheiro, veio-lhe a frustação de não ter alcançado seus objetivos. O rei não cumpriu com suas promessas. Contudo, ainda tinha em suas mãos, isto é, sob sua administração parte do poder local e regional, visto que ocupava o posto de Provedor dos Quintos em Taubaté. Logo, voltou a sua antiga rotina.

Dentro dos limites que circundavam os colonos, Pedroso estava, pode-se dizer, na fronteira. A posição que ocupava não deve ser minimizada. O exercício de suas atribuições foi se elevando ao longo do tempo e, junto deste, a própria imagem de Pedroso, o seu

\footnotetext{
${ }^{506}$ Idem, Ibidem. p. 630.

${ }^{507}$ Idem, Ibidem. p. 630.

${ }^{508}$ Idem, Ibidem. p. 630.

509 "Parecer do Capitão-mor Carlos Pedroso da Silveira...". AHU - Conselho Ultramarino Brasil/Rio de Janeiro. Cx. 7, doc. 741. p. 71.
} 
prestígio entre a sociedade e, principalmente, entre as autoridades oficiais. Ao ser nomeado Provedor dos Quintos, no contexto da inicial exploração mineira, alcançara o seu auge e, por isso mesmo, o ponto máximo disponível e acessível aos colonos, pelo menos em se tratando dos habitantes da região. Outro aspecto que deve ser levado em conta, além dos citados limites, é a valorização daquilo que Pedroso desejava: o hábito de uma ordem militar portuguesa, no caso a de Cristo. De acordo com Fernanda Olival, houve um enrigecimento do estatuto de limpeza de sangue entre o último quartel do século XVII e as três primeiras décadas do seguinte. Isto seria um apelo da elite para se valorizar a própria distinção, isto é, visava-se dificultar o acesso a ela. Para a autora, suas principais causas foram a chegada do Infante D. Pedro ao trono em 1667 e o consequente reforço nobiliárquico; "as reações ao sacrilégio de Odivelas de 1671; os boatos sobre o perdão geral e as tensões decorrentes da suspensão do Santo Ofício entre 1674 e 1681."510 No caso de Pedroso, o motivo para a não concessão da mercê foi, como visto, a incompatibilidade do tempo de serviços prestados. Não foi mencionada a questão de pureza de sangue. Na verdade, a investigação quanto a isso ocorria num passo adiante, quando se dava início ao "processo de habilitação", coisa que não foi feita com Pedroso. De qualquer forma, não obstante o parecer favorável à concessão da mercê, esta lhe foi negada, o que pode ser um reflexo das ações que visavam fortalecer os valores nobiliárquicos daquele momento. ${ }^{511}$

Restava-lhe voltar ao posto de Provedor dos Quintos, o que não era de se desprezar. Continuou suas funções neste cargo por mais alguns anos, ora em Taubaté, ora em Parati. Ainda foi nomeado, em 1705, Procurador da Coroa na capitania de Nossa Senhora da Conceição de Itanhaém e, em seguida, Capitão-mor da mesma capitania ${ }^{512}$. E foi mais

${ }^{510}$ OLIVAL, Fernanda. "Rigor e Interesses: os estatutos de limpeza de sangue em Portugal." In: Cadernos de Estudos Sefarditas. n. 4, 2004. p. 159. Sobre a Inquisição, o processo de Habilitação e a distinção social, Ver: RODRIGUES, Aldair Carlos. Sociedade e Inquisição em Minas Colonial: os familiares do Santo Ofício (1711-1808). Dissertação de Mestrado: FFLCH-USP, 2007. Em especial o capítulo III: "O cargo de Familiar do Santo Ofício: definição e requisitos".

${ }^{511}$ Registra-se aqui os agradecimentos a Aldair Carlos Rodrigues que, gentilmente, confirmou em arquivos portugueses, mais precisamente nos corpos documentais intitulados "Registro Geral de Mercês" e "Mesa de Consciência e Ordens/Habilitação da Ordem de Cristo", ambos tutelados pelo Arquivo Nacional da Torre do Tombo, a não habilitação de Pedroso em qualquer hábito militar que seja.

512 "Provisão de Procurador da Coroa e Fazenda Real da Capitania de N. S. da Conceição de Itanhaém a Carlos Pedroso da Silveira, dada por D. Fernando Martins Mascarenhas de Lencastro, de 5 de setembro de 1705" e "Patente de Capitão-mor da Capitania de N. S. da Conceição de Itanhaém a Carlos Pedroso da Silveira, dada por D. Fernando Martins Mascarenhas de Lancastro, 
além. Em 1713, obteve do Governador da capitania de São Paulo e Minas, Dom Brás Baltasar da Silveira, a patente de Mestre de Campo e Capitão-mor regente das vilas de Taubaté, Guaratinguetá e Pindamonhangaba.

Sabe-se que "nos cargos que exerceu o seu procedimento foi sempre o mais correto e exemplar" ${ }^{\text {,513, }}$, ao ponto de, durante os dez anos em que esteve no posto de Provedor dos Quintos, "por várias vezes em perigo a sua vida por obrigar aquelas pessoas que não queriam quintar o ouro que pertencia aos reais quintos." ${ }^{\text {E }} \mathrm{E}$ aqui que se percebe a ambiguidade das atitudes de Pedroso. Se, num primeiro momento, esteve aliado aos interesses do grupo sertanista local (Taubaté e região), posteriormente, visando a própria ascensão social, procurou alinhar-se oficialmente ao poder metropolitano. Não há dúvida de que Pedroso foi, por muito tempo, o elo de ligação do poder local com o poder monárquico.

Esta posição, apesar das vantagens, lhe custou muito caro. "A severidade com que exercia e praticava a justiça, o inimizou com os poderosos, que experimentaram sem torcêlo o seu caráter integérrimo", e num momento oportuno, recém chegado das minas, "mandaram matá-1o".515 Ferido com um tiro numa emboscada armada contra ele, veio a falecer em 17 de agosto de agosto de 1719. Não se sabe ao certo quem foi ou quem foram os autores do crime. Carvalho Franco denuncia que o Conde de Assumar, em carta a Bartolomeu de Sousa Mexia, datada do Carmo a 9 de fevereiro de 1720, conta que foi um irmão de Domingos Rodrigues do Prado, famoso bandeirante de Taubaté, quem assassinou Pedroso. $^{516}$

Tal fatalidade logo se espalhou. Sabendo do ocorrido, o própio Conde de Assumar tratou rapidamente de tomar algumas providências. A primeira delas foi enviar uma carta à viúva, a qual tinha por conteúdo o seguinte:

de 5 de outubro de 1705." Ambos em: Documentos Interessantes para a História e Costume de São Paulo. Publicação Oficial: Arquivo do Estado de São Paulo; São Paulo: Estabelecimento Gráfico Irmãos Ferraz, 1930. Vol. LI. p. 269-271 e 310 e 311, respectivamente.

${ }^{513}$ VASCONCELOS, Diogo de. Op. cit. p. 208.

514 "Patente de Capitão-mor da Capitania de N. S. da Conceição de Itanhaém a Carlos Pedroso da Silveira, dada por D. Fernando Martins Mascarenhas de Lancastro, de 5 de outubro de 1705.” Op. cit. p. 310.

515 VASCONCELOS, Diogo de. Op. cit. p.208. Cf. também: Inventário de Carlos Pedroso da Silveira (1719). Cx: 1716-1719. A.H.M.T.

${ }^{516}$ FRANCO, Francisco de Assis Carvalho. Op. cit. p. 381. Silva Leme também é da mesma opinião. Cf. LEME, Luiz Gonzaga da Silva. Genealogia Paulistana. São Paulo: Duprat \& Comp., 1904. vol. 3. p. 316. 
Minha Senhora. Sendo em Vmce. as obrigações de sentir o desastrado sucesso do Mestre-de-campo Carlos Pedroso, não foi menos em mim o sentimento, quando me chegou esta notícia porque considerava nele um bom vassalo, servidor de Sua Majestade, por cujo motivo ainda é mais a minha impaciência de não poder desembaraçar-me dos negócios deste governo para dar pronta satisfação, que deste caso se deve a Deus, a elRei, e ao mundo, e a Vmce; mas do modo que posso remeti a Vmce as ordens inclusas para o juiz ordinário dessa comarca procurar tirar devassa, prender os delinquentes e castigá-los, como merece a sua atrocidade; e Vmce pode usar de ambas, quando lhe pareça; e no mais deve Vmce conformar-se com as disposições do Altíssimo, ainda que justa a sua mágoa e a sua pena não podem voltar atrás este sucesso e para tudo que eu prestar me terá pronto. Vila do Carmo, 20 de outubro de $1720 .^{517}$

Depois mandou outra para o Ouvidor da capitania.

Mui admirado me tem a notícia, que me chega do assassinato do Mestrede-campo Carlos Pedroso da Silveira, e que em estando por Juiz dessa vila, não procurasse logo tirar devassa e prender os delinquentes, remetendo-os, para onde estivessem seguros; porque, além de ser este um caso mui agravante da Justiça, e o morto uma pessoa principal, devendose por uma e por outra causa dar satisfação a esta queixa, para que servisse de exemplo, e não continuassem esses distritos a ser o covil de todos os assassinos; Vmce tem passado este caso, como se fosse uma leve culpa, temendo talvez mais a indignação dos homens que a de Deus; assim lhe ordeno que logo que receber esta, procure tirar devassa e prender os matadores, remetendo-os logo para São Paulo ao Ouvidor geral: e que quando nisto haja a menor dúvida Vmce há de responder dela, e então procederei com Vmce como melhor e parecer. Deus guarde etc. Vila do Carmo 20 de outubro de $1715^{518}$. D. Pedro d'Almeida. ${ }^{519}$

Apesar de todo o esforço das autoridades, se é que houve tanto assim, ninguém foi responsabilizado pelo crime.

Receosos pelo ocorrido, o restante da sua família foi obrigada a sair da vila, indo se instalar nas terras localizadas no Rio Verde, caminho das Minas, na paragem chamada Caxambu, terras estas que Pedroso tinha obtido por sesmaria dada por D. Francisco Martins Mascarenhas, por provisão de 30 de setembro de 1706.

${ }^{517}$ VASCONCELOS, Diogo de. Op. cit. p.208-209.

${ }^{518} \mathrm{Na}$ verdade o ano foi de 1720 . Não se sabe se o erro foi do próprio Conde de Assumar ou de Diogo de Vasconcelos.

${ }^{519}$ VASCONCELOS, Diogo de. Op. cit. p. 209. 
Seguros na nova moradia, investiram nas plantações de mantimentos destinados aos viajantes que se dirigiam para as Minas e acabaram por ser considerados "os primeiros grandes fazendeiros que ali se estabeleceram." 520

Finalmente, após tudo o que foi exposto, vê-se que Pedroso transitou entre as fronteiras do vilão e do herói, do colono e do governo, da Colônia e da Metrópole, do público e do privado, e, por último, da glória e do esquecimento.

${ }^{520}$ FRANCO, Francisco de Assis Carvalho. Op. cit. p. 382. 


\section{CONSIDERAÇÕES FINAIS}

Ao longo de todo o tempo destinado a esta pesquisa o número de estudos encontrados sobre o bandeirismo se ampliava cada vez mais. Por um lado, a constatação da existência de uma grande quantidade de trabalhos era vantajosa porque permitiu o aprofundamento no tema, por outro, a divergência das teses contribuiu para a complexidade na definição dos objetos analisados.

A discordância entre os estudiosos foi evidente. Dialogavam sobre o uso dos termos bandeira, entrada, jornada, expedição, viagem e carregação, sobre seus significados, sobre seus objetivos (caça ao índio, prospecção, reconhecimento, etc), sobre suas fontes financiadoras e seus participantes. Diante de uma enorme lista de teses, verificou-se, após uma pesquisa documental, a dificuldade em se fazer distinção entre aqueles termos, principalmente entre bandeiras e entradas sertanistas, assim como entre os termos bandeirantes e sertanistas, já que ambos se referiam às ações de adentrar ao sertão e aos indivíduos que delas participavam. É possível que, à época, houvesse algum tipo de classificação, todavia, entende-se que o nome dado a um ou a outro tipo de expedição ampliou seu raio de referência ao longo do tempo, até ser utilizado como significado comum, isto é, os termos em questão podem ter se popularizado a ponto de sofrer esvaziamento de sentidos mais específicos.

Por exemplo, se em princípios da colonização portuguesa na América as expedições com vistas ao reconhecimento e ao combate contra os indígenas eram quase que exclusivamente organizadas pelo poder oficial e de cunho basicamente militar, tempos depois esta configuração sofreu mudanças, sendo acrescentadas intenções econômicas e maior envolvimento de particulares. As mutações eram comuns e faziam parte da própria dinâmica da Colônia, e neste processo de constantes readaptações seria um erro, hoje, querer traduzir num termo ou noutro uma prática que perdurou durante alguns séculos e que viu sua essência se transformar de acordo com as multi-realidades existentes. Nesse sentido, bandeirismo ou sertanismo foram tomados como sinônimos das atividades voltadas ao sertão, isto é, dos esforços particulares ou oficiais, com objetivos de apresamento e/ou prospecção, de menor ou maior envergadura e efetuadas em qualquer região do Brasil. 
Sobre a especialização do paulista nos assuntos do sertão, viu-se que a economia, a religião, a sociedade, a política, a geografia, a ética e a raça foram os caminhos trilhados pelos estudiosos a fim de se encontrar uma explicação. Foram, porém, os estudos de Sérgio Buarque de Holanda o ponta-pé inicial para a compreensão das especificidades regionais, isto é, salientou a noção de que cada época e cada região tinham seu próprio centro de gravidade formado em virtude da interação entre o meio, a cultura e a sociedade, e nesse conjunto de forças era possível encontrar a relação paulista/bandeirante. Foi o que fez John Monteiro ao definir a prática do bandeirismo como uma ação que procurava sustentar a crescente economia de São Paulo ao oferecer constantemente mão-de-obra escrava para a produção agrária e pecuária. Esta realidade também foi observada em Taubaté.

Não obstante as diferenças existentes na colônia houve uma "unicidade estrutural na formação social brasileira", como afirmou Ilana Blaj. Logo, o paulista, em especial o bandeirante, não deve ser visto como uma "raça de gigantes", um povo "eleito", de qualidade superior, nascido para adentrar o sertão. Portanto, os bandeirantes foram considerados apenas como colonos que devido às circunstâncias materiais encontraram nas incursões sertanistas uma saída para a montagem e manutenção da máquina de exploração em São Paulo. O bandeirismo era, em primeiro lugar, uma prática econômica.

Quanto ao suposto isolamento e até incompatibilidade de São Paulo aos moldes da exploração colonial, viu-se que os paulistas foram extremamente úteis à Metrópole, principalmente nas décadas que se seguem após a Restauração portuguesa ocorrida em 1640. Diante de uma forte crise econômica que colocava em risco o próprio Império português, os bandeirantes paulistas foram procurados pelas autoridades reais que, oferecendo títulos, honras e mercês, visavam estabelecer um contrato de prestação de serviços em torno da descoberta de minas de metais e pedras preciosas. Esta relação fez parte do processo que culminou no achamento das minas de ouro ocorrido na década de 1690. Não foi possível precisar a intensidade desta influência visto que as empresas sertanistas que desbravaram o interior do Brasil eram formadas por fatores internos e externos, ou seja, tal processo histórico não pode ser creditado apenas a um ou a outro fator, foi uma mescla de necessidades, de sobrevivência e de exploração.

Tanto quanto a vila de São Paulo, Taubaté teve papel importante neste processo e, por isso, mereceu ser estudada. Foram encontrados indícios de que tal vila foi fundada 
devido a intenções propriamente sertanistas que também contribuíram para o devassamento e ocupação da região do vale do Paraíba. O bandeirismo fez parte do surgimento de Taubaté.

Em relação às características sociais da vila, o índio predominava. A sua presença maciça foi fruto das atividades de preamento organizadas pelos próprios habitantes dela. Eram eles fundamentais para a vida econômica da vila já que a produção agrária dependia desta mão-de-obra. Já a proporção de negros africanos era muito pequena, só aumentando após o início do século XVIII devido às descobertas metalíferas e à consequente posse de maior riqueza nas mãos dos habitantes da vila, o que possibilitou a aquisição de tais negros. Os livres, entre brancos e mestiços, se mantiveram em torno de 1/3 da população, uma minoria, portanto.

As informações obtidas na documentação demonstraram que muito do que se sabia sobre a economia de Taubaté estava equivocada. Por exemplo, ao invés de uma policultura de subsistência, que sobrevivia à custa do trabalho familiar, e que só teve alguma evolução após a descoberta do ouro nas Gerais, constatou-se uma interessante dinâmica comercial de abastecimento local e regional, dinâmica esta reconhecida atualmente como parte da estrutura colonial de exploração.

Durante os anos após as descobertas das minas, com a injeção de riquezas e a abertura de um novo mercado consumidor, a produção e o mercado local ganharam impulso, sofrendo mudanças bastante significativas. Além da aquisição de mão-de-obra africana, houve a ampliação da produção de cana-de-açúcar e seus derivados em detrimento de outros produtos. A pesquisa apontou para uma clara mercantilização da economia da vila. A disponibilidade de liquidez através do ouro também permitiu o aquecimento das transações econômicas, com destaque para os empréstimos que ofereciam o acesso da população aos meios produtivos.

Não obstante as afirmações de alguns estudiosos que apontavam para presença de uma população livre formada apenas por pequenos proprietários policultores onde, supostamente, haveria uma riqueza bem distribuída, sob uma espécie de democracia econômica, a desigualdade na distribuição da riqueza foi evidente, o que gerou uma sociedade bastante hierarquizada. Todavia, os interesses econômicos se mostraram iguais. Desde os mais ricos aos mais pobres, a maior parte do montante de seus bens estava 
materializada nos escravos e no setor rural. De fato, era uma sociedade assentada no sistema escravista de produção.

Enfim, em termos sócio-econômicos, Taubaté era uma vila de traços desiguais. O posicionamento dos indivíduos na sociedade variava conforme suas posses, mas isso não era tudo, havia o critério da participação ou não nos meios de comando político-militar que também definia a divisão no status social da população. Tanto para o poder político como para o militar, verificou-se que um pequeno grupo os controlava, o que lhes garantia maior distinção e prestígio.

Diante deste contexto foi possível pinçar alguns aspectos do grupo sertanista local, parte deles confrontou antigas concepções. Primeiramente, constatou-se a não generalização da prática sertanista, isto é, não era toda a sociedade que participava dos movimentos que adentravam o sertão. Logo, a extensão da prática sertanista dada automaticamente à população da capitania deve ser repensada. No caso da vila de Taubaté pôde ser visto que esta natural associação não se fundamentou.

Em relação aos interesses econômicos dos bandeirantes, notou-se, assim como para o restante da população, a maior parte de suas riquezas estava depositada nos escravos e no setor rural, ou seja, participavam de uma economia agrária e escravista. Na verdade, nem os próprios sertanistas viviam somente das expedições, além destas praticavam outras atividades econômicas. Dessa maneira, não é correto afirmar que o sertanista vivia única e exclusivamente do bandeirismo.

Sobre a organização das bandeiras e a necessidade da posse e uso de alguns materiais pelos sertanistas, ocorria que os gastos exigidos na montagem de uma expedição não eram poucos. Assim, aqueles que não dispunham de recursos serviam-se de outras pessoas mais abonadas a fim de adquirirem empréstimos para a realização das jornadas. Tais gastos e a procura por financiamento incentivavam as negociações para além do círculo dos próprios sertanistas. Muitas transações econômicas eram feitas indiretamente sob a influência das necessidades e oportunidades advindas do movimento bandeirante.

A fim de minimizar aqueles encargos formavam-se associações. De um lado havia a disponibilização de recursos materiais, e do outro a prestação de serviços, ambos sempre cientes das responsabilidades antes e depois da viagem, tanto no sucesso quanto no fracasso. Esses acordos eram feitos com pessoas estranhas, com amigos ou parentes mais 
distantes, porém, na maioria das vezes, eram firmados dentro dos núcleos familiares, perante os laços de união e afinidade muito úteis para o bom andamento dos negócios, além do que serviam para iniciar outros membros da família na tradição sertanista.

Como grupo social, os sertanistas oscilaram entre a posse de maior ou menor poder econômico, mas sempre se mantiveram numa confortável posição, no topo, como uma elite econômica. Era um grupo que, como todo o restante da população, tinha sua base econômica assentada nos escravos e no setor rural. Porém, se diferenciava apenas pelo fato de utilizar parte dos recursos financeiros e humanos nos empreendimentos que demandavam o sertão à procura de mão-de-obra, metais e pedras preciosas.

Em termos de níveis sócio-econômicos, os sertanistas não formavam um bloco homogêneo, nem usufruíam dos mesmos padrões de vida, de conforto, de alimentação, de vestimenta, etc. A desigualdade também os atingia em linha vertical.

Economicamente, as bandeiras eram atividades que despertavam interesse em parte da sociedade devido às possíveis vantagens. Serviam de oportunidade de enriquecimento ou, pelo menos, de uma melhora no padrão de vida, tornando-se uma atração para muitas pessoas. Todavia, não eram todos os envolvidos que alcançavam maior conforto financeiro, ao contrário, muitos ainda continuavam dependentes de credores. Daí a constatação de que os mais pobres tinham por regra contribuir com a própria mão-de-obra para a execução das bandeiras, enquanto que os mais ricos apenas injetavam parte de seus recursos disponíveis.

Portanto, a partir de uma análise estritamente econômica viu-se que os esforços em prol do movimento bandeirista serviram para manter em funcionamento a estrutura produtiva e comercial da vila de Taubaté, principalmente porque geravam as sucessivas inserções de mão-de-obra indígena e, depois, de ouro. O sucesso do empreendimento também prestou para solidificar a posição social de seus agentes no comando financeiro local, firmando-se como uma elite econômica. No entanto, com a virada do século e com a exploração das minas, essa posição privilegiada esteve ameaçada por outros setores da sociedade até então não envolvidos com o círculo sertanista. Houve uma equiparação dos poderes econômicos. Se, por um lado, o grupo sertanista obteve sucesso uma vez que viabilizou a consolidação e manutenção de seu poder econômico, por outro lado, o próprio sucesso nas entradas sertanistas, responsável pela escravização de índios e pelo achamento de ouro nas Gerais, também favoreceu o enriquecimento do restante da sociedade não só 
devido a oferta de mão-de-obra necessária para o funcionamento do sistema produtivo como também com a oportunidade da exploração mineral, além da abertura de novos mercados consumidores na região das minas.

Já que no âmbito econômico os sertanistas não foram os únicos beneficiados, outros elementos também serviram de critérios de elevação de status, como o exercício de cargos públicos e a posse de patentes militares. Assim, os sertanistas buscaram predominar nos núcleos de mando local, constituindo na maioria do contingente detentora do poder administrativo e militar. Tal situação foi ameaçada nas primeiras décadas do século XVIII. A melhor distribuição da riqueza serviu negativamente para o grupo bandeirante, pois este viu crescer a força de outros indivíduos que não faziam parte do seu meio. Conscientes, talvez, da diminuição do seu poder econômico, buscaram cada vez mais ocupar cargos no governo local como uma forma de manter o antigo status de elite, mesmo que isso tenha permanecido apenas no campo simbólico. Daí o aumento da procura pelos cargos políticos e militares por parte dos sertanistas nas décadas iniciais do século XVIII. Portanto, o aumento no interesse pelos cargos camarários e patentes militares corresponderam a uma possível tentativa dos sertanistas taubateanos de manter o seu status de grupo dominante, fazendo com que mais bandeirantes buscassem estas distinções.

Com forte envolvimento no bandeirismo taubateano, Carlos Pedroso da Silveira serviu de exemplo para ilustrar as características tanto da prática sertanista quanto do comportamento da sociedade paulista diante do processo de colonização e exploração do interior do Brasil.

De origem seleta, Pedroso nasceu no interior de uma camada social de elevado prestígio, detentora de riquezas materiais, de patentes militares e de cargos na governança, condição esta bastante favorável, pois a posse de cabedal financeiro e educacional foi fundamental para a manutenção e melhora do seu status. Ainda jovem, Pedroso já possuía o instrumental necessário para o exercício de funções político- militares.

Em Taubaté, suas atividades econômicas, suas relações sociais e políticas estiveram extremamente ligadas ao grupo dominante local, qual seja, o grupo bandeirante, fazendo com que seus interesses se ajustassem aos da elite aí estabelecida. Pedroso se envolveu nas entradas sertanistas, era dono de índios escravizados "ilegalmente”, participou de negócios em torno dos empréstimos - inclusive de ouro não quintado -, foi produtor agrário, 
principalmente de cana-de-açúcar, e também fabricante de telhas. Foi respeitado e ganhou poder de influência devido as muitas funções político-militares que ocupou.

Entretanto, Pedroso também se posicionava a favor dos interesses da Coroa, comportando-se como um fiel vassalo no exercício de tais cargos. Não fez parte, apenas, do seleto grupo que detinha em suas mãos o controle da governança local, mas também alçou maiores vôos chegando a ocupar postos de maior envergadura. Para tanto não bastou apenas preencher quesitos como a origem familiar e as relações sociais, foi preciso orientar seu comportamento e prestar serviços que provassem a sua capacitação e fidelidade. No famoso episódio da declaração do ouro, Pedroso soube aproveitar a oportunidade, ganhando a confiança das autoridades coloniais, porém isso acarretou no alinhamento de seus interesses aos do poder oficial frente aos da elite taubateana.

Anteriormente aliado a tal elite, Pedroso desejou subir os níveis hierárquicos, o que lhe daria maior poder e distinção. Suas atitudes quanto à participação e, principalmente, à entrega das amostras de ouro ao governador do Rio de Janeiro revelaram o seu interesse em ser reconhecido como fiel vassalo perante os representantes diretos do poder monárquico e merecedor de honras e prêmios. De imediato, foi eleito o responsável pela Casa de Fundição de Taubaté, cargo de extrema importância visto que sua função foi recolher os impostos taxados sobre o ouro e combater os infratores.

A fim de aumentar ainda mais sua qualidade social pediu ao Rei um hábito de Cristo com tença e um posto de comando da primeira companhia de infantaria que estivesse vago no Rio de Janeiro. Como praxe, listou e comprovou os principais serviços prestados à Coroa, com destaque para a declaração da descoberta de ouro e a entrega de algumas arrobas do metal recolhido na casa de fundição. Não obstante os esforços de Pedroso e a promessa do rei em recompensá-lo, seu pedido foi negado. Ao que parece, tinha atingido os limites dentro do quadro estamental ordenado pelos valores culturais do Antigo Regime. De volta à rotina na vila, ainda como Provedor dos Quintos, posição extremamente importante, as inimizades criadas com a sua função no aparelho tributário que ia de encontro aos interesses da elite local, levaram ao seu assassinato.

Concluindo. A capitania paulista, sua população e suas atividades econômicas tiveram sim as suas especificidades tão marcadas em seu desenvolvimento histórico. Aliás, outras regiões do Brasil também tiveram as suas. Esta multi-realidade era parte 
indissociável do processo de colonização. A familiaridade do paulista com o sertão foi uma resposta à própria condição material e cultural a que estava sujeito, logo, o bandeirismo que era praticado por uma parcela desta população foi uma atividade com vistas a suprir as necessidades advindas da realidade local como, por exemplo, a incessante demanda por mão-de-obra indígena destinada à crescente produção agro-pecuária. Esta produtividade que alimentava cada vez mais a dinâmica comercial, inclusive com outras vilas e capitanias, contrariou o suposto isolamento e a pobreza generalizada atribuído às vilas paulistas. Por falar em isolamento e marginalização, o próprio bandeirismo que por muito tempo foi taxado como "contraditório" ao sistema colonizatório, serviu de elo de ligação entre as elites paulistas, que desta prática se sustentavam, pelo menos em Taubaté, e as autoridades reais. A sua utilidade ficou clara quando a Coroa portuguesa solicitou por diversas vezes que os bandeirantes paulistas percorressem o sertão em busca das tão sonhadas minas de ouro. Essa relação, baseada em interesses de ambos os lados, se firmou por meio das regras político-culturais do Antigo Regime, isto é, num velho jogo de prestações de serviços e ofertas de recompensas. Foi o que se viu nas cartas reais direcionadas aos paulistas de prol e no caso frustante de Carlos Pedroso da Silveira. De qualquer maneira, o bandeirismo como atividade intimamente relacionada à realidade local fazia parte da própria engrenagem responsável pelo andamento da colonização do Brasil, em especial, do seu desconhecido e temido interior. 


\section{FONTES}

\section{Manuscritas}

ARQUIVO HISTÓRICO MUNICIPAL DE TAUBATÉ

- Livros de Registros e Escrituras: Caixa 157 (1676-1700) e Caixa 158 (1700-1711);

- Inventários e Testamentos (1649-1720).

Obs: os que estão em negrito são os inventários que possuem testamentos anexados ao documento e os que contêm um (*) são os considerados sertanistas - vale lembrar que isso também inclui inventários de cônjuges. Além disso, alguns documentos foram considerados inválidos devido à dificuldade de compreensão, seja por estar incompleto ou pelo estado de deteriorização.

Dionízia de Góis

CAIXA: 1649-1677 (cartório do $2^{\circ}$ Ofício)

Estevão da Cunha 1649

Jorge Lopes

1650

João do Prado Martins (*)

1651

Francisca Cardoza

1653

1655

Violante de Siqueira

1656

Maria Delgada

1657

Anna Rodrigues

1658

José de Paris

1659

Manoel da Costa Cabral 1659

João Martins (*)

1660

Manoel Monteiro Bezerra (*) 1660

Manoel Coelho de Souza (*) 1660

Custódio Dias de Macedo 1660

Francisco de Morais (*) 1660

Jorge Lopes Gil 1660

Domingos Dias Félix (*) 1660

Domingos Pires Valladão 1660

Maria da Luz Camargo 1661

Catharina Dias 1661

João Azeredo Coutinho (*) 1661

Antonio Gonçalves 1662

Antonio de Faria Albernaz (*) 1663

Francisca Luis 1663

Antonio Rodrigues 1663

Antonio Ribeiro 1664

Jorge da Costa 1664

Luis Fernandes de Moura (*) 1665

Cristóvão Rodrigues de La Penha 1666

Miguel Fernandes Edra (*) 1667 
Catharina da Costa 1667

Miguel de Góis 1668

Pedro Gil (*) 1668

Sebastião Gonçalves de Barros $\left(^{*}\right) \quad 1668$

Isabel de Araújo 1669

João Correa 1670

Paulla Fernandes $\quad 1670$

Domingos Fernandes 1670

Domingos Gomes da Costa $(*) \quad 1671$

Sebastiana de Torres $\left(^{*}\right) \quad 1671$

João Luis 1671

Francisco Botelho (*) 1671

Joana Ramalho 1672

Francisca dos Anjos (*) 1672

Antonio Rodrigues do Prado 1672

Antonia Furtada (*) 1672

Bernarda Rodrigues do Prado (*) 1672

Henrique da Cunha Lobo $(*) \quad 1672$

Manoel Correa de Andrade (*) 1673

Sebastião Luis 1673

Lourenço da Veiga 1673

Antonio Timudo (*) 1673

Antonio Vieira da Maya (*) 1674

Luis de Sousa Ferreira 1674

Maria Moreira (*) 1675

Domingos Arenço Botelho 1676

João Delgado de Escovar 1676

Pedro Aranha 1677

Sebastião Vaz Cardoso $\left.{ }^{*}\right) \quad 1677$

Antonio Teixeira Side (*) 1678

Francisco Martins Farel 1678

João da Costa 1678

Alberto Lobo Louzada $\quad 1680$

Manoel Borges Conseiro 1680

João Pereira Quaresma $\quad 1680$

Margarida da Costa $\quad 1680$

Bernardo Bonfillio 1681

Antonio Antunes Barboza 1681

João Correa Soares 1682

Antonio Lourenço 1682

André Fernandes Urtunha 1682

Mariana de Camargo 1683

Isabel da Cunha $(*) \quad 1683$

Sebastião Gil 1683

Antonio Rodrigues 1683

José de Castilho $\left.{ }^{*}\right)$ 
Francisco Gonçalves Delgado (*) 1684

Antonio Raposo Barreto (*) 1684

Francisco Gil 1684

João Vieira da Maya 1684

Domingas Ribeira (*) 1684

Ignácio de Camargo 1684

Paulla Cunha (*) 1684

Potência Leite 1685

Amaro Gil 1685

Bartolomeu da Cunha Gago (*) 1685

José Cubas Rapozo (*) 1685

Francisco Borges Rodrigues 1685

Paula Fernandes de Oliveira 1685

Margarida Bicuda 1686

Belchior da Cunha (*) 1686

Catharina Nunes (*) 1686

Sebastião Martins Pereira 1687

Catarina Portes delRey 1687

Maria Fragosa 1687

Helena Rodrigues (*) 1687

Miguel de Almeida Cunha (*) 1687

Francisco Pedroso (*) 1687

Catarina Dias da Luz 1688

Pascoal Gil (*) 1688

Maria de Oliveira $\quad 1688$

Marta de Miranda 1689

Joseph de Oliveira 1689

João Pedroso (*)

CAIXA: 1691-1699 (cartório do $2^{\circ}$ Ofício)

Salvador Gil de Siqueira (*) 1691

Ana Vaz Cardosa da Cunha 1692

Domingas Lobo (*) 1692

Antonio de Madureira Moraes $\quad 1692$

Antonio da Costa Gil 1692

Manoel Gil Cubas 1693

Maria Ribeiro 1693

Pascoal Dias Furtado 1694

Antonio de Siqueira Escobar 1694

Manoel Gil de Siqueira 1695

Francisco Farel 1696

Manoel Nunes Pereira 1696

João Barbosa Correa 1696

José Gonçalves (*) 1696

Manoel de Figueiredo 1696

Francisco Coelho de Abreu (*) 1697

Maria Borges 1697

João Pereira Xiberia 1697 
Francisco Correa da Veiga 1697

Domingos Martins do Prado 1697

Clemente Vieira 1698

Bento Gil de Siqueira 1698

João Tavares 1698

Manoel Paes Cordero (*) 1698

Ignês Gonçalves Gil (*) 1698

Cornélio da Rocha 1699

Antonio Gil 1699

Ignes Gonçalves 1699

Diogo Teixeira da Cunha (*) 1699

Rosa Maria da Costa 1700

Pedro Ayres de Aguirre $\quad 1700$

Miguel Gil de Siqueira $\quad 1700$

Catarina de Siqueira $\quad 1700$

Felipa Gago (*) 1701

Ana Maria de Siqueira 1701

Maria de Unhate Madurga (*) 1701

Manoel da Costa Pinheiro 1701

Catarina Sisneira de Albernaz (*) 1701

João de Faria Refojo 1702

Henrique da Cunha 1702

Maria Bicuda Leme $\quad 1702$

Vitória de Siqueira $\quad 1702$

Antonia Moreira 1702

Francisco da Costa Cabral (*) 1702

Catarina Rodrigues de Siqueira (*) 1702

João Cabral de Silva (*) 1702

Domingos Soares $(*) \quad 1703$

Sebastiana de Unhante 1703

Sebastião de Arruda 1703

Maria de Urtunha 1703

Ana Vaz Bicuda (*) 1703

Roque Vieira 1703

João da Silva Arreiro 1703

Manoel de Vasconcelos (*) 1703

Pedro Teixeira da Cunha (*) 1704

Bartolomeu Bueno de Mendonça 1704

Maria da Cunha Lobo 1704

Catarina Bicuda 1705

Salvador Gil de Siqueira 1706

Marina de Chaves 1706

Antonio Correa de Castilho (*) 1706

João Portes delRey (*) 1707

Gaspar de Magalhães (*) 1708

Antonio Delgado de Escobar $(*) \quad 1708$ 
Domingos Félix Lobo

1709

Domingos Gonçalves Silva (*) 1709

CAIXA: 1709-1715 (cartório do $2^{\circ}$ Ofício)

Henrique da Cunha

1709

Pedro Domingos Requeixo 1709

Francisco Rodrigues do Prado 1709

Bernarda de Souza da Silveira (*) 1710

Manoel da Costa Cabral (*) 1711

Maria Bicuda de Escobar 1712

Catarina do Prado 1712

Maria Barbosa dos Anjos 1713

Sebastião Gil 1713

Manoel Dias Ferreira (*) 1713

João Delgado de Escobar (*) 1713

Antonio Carvalho 1713

Antonio Rodrigues Camacho 1714

Domingos Gomes da Costa 1714

Pedro Vieira 1714

Antonio da Cunha Gago (*) 1714

Manoel Gil 1715

Manoel Gil de Siqueira 1715

CAIXA: 1716-1719 (cartório do $2^{\circ}$ Ofício)

Cap. Domingos Rodrigues do Prado (*) 1715

Jerônimo da Veiga Correa (*) 1716

Messias Rodrigues de Godoy $\quad 1716$

Gaspar Martins 1716

Francisco Barbosa Ribeiro 1716

Sebastião Cardoso 1716

Ana Ribeiro de Alvarenga 1716

Francisco Rodrigues Moreira (*) 1716

Maria Nunes Rodrigues 1716

Isabel da Rosa (*) 1716

Domingos Rodrigues do Prado (*) 1717

Serafino Correa $(*) \quad 1717$

Antonia de Serra Cordera 1718

Margarida Bicuda 1718

Maria da Silva 1718

Matheus da Silva Rosa 1718

Francisco Pinto de Macedo 1718

Sebastião de Sousa $\quad 1718$

Andresa de Castilho 1718

Pedro da Fonseca de Carvalho 1718

Carlos Pedroso da Silveira (*) 1719

Miguel Rodrigues do Prado 1719

Maria Nunes de Miranda 1719

Joana de Freitas 1719

CAIXA: 1720-1723 (cartório do $2^{\circ}$ Ofício) 


\section{Impressas}

Documentos Interessantes para a História e Costume de São Paulo. Publicação Oficial: Arquivo do Estado de São Paulo; São Paulo: Typographia Aurora, 1896. Vol. XX.

"Correspondência Interna do Governador Rodrigo César de Menezes (1721-1728): Registro da primeira carta que se escreveu as Câmaras de todas as Villas desta Capitania”, 7.9.1721, p.4-5.

Documentos Interessantes para a História e Costume de São Paulo - Documentos relativos a História da Capitania de S. Vicente e do Bandeirismo (1548-1734), existentes no Arquivo do I.H.G.B., coligidos, copiados e anotados, de ordem do Governo do Estado. Publicação Oficial: Arquivo do Estado de São Paulo; São Paulo: Estabelecimento Gráfico Irmãos Ferraz, 1929. Vol. XLVIII.

"Nota do alvará régio concedendo ordenado a Luis Martins, mandado a examinar as minas de metaes, que se constava existirem nas terras do Brasil, de 7 de setembro de 1559”, p. 31 32 .

"Carta do coronel Pedro Barbosa Leal ao Conde de Sabugosa, vice-rei do Estado do Brasil, sobre as várias incursões realizadas no sertão da Bahia em busca de minas metallicas, desde o pretenso descobrimento das de prata por Belchior Dias Moreya, de 22 de novembro de 1725", p.59-104.

Documentos Interessantes para a História e Costume de São Paulo - Documentos relativos a criação, extinção e desmembramento das capitanias de que resultou $S$. Paulo, como circunscrição política do Brasil, ou respeitantes a sua extensão jurisdicional e as suas questões de limites, peças históricas essas existentes todas no Arquivo Nacional, e copiadas, coligidas e anotadas, de ordem do governo do Estado. Publicação Oficial: Arquivo do Estado de São Paulo; São Paulo: Casa Vanorden, 1929. Vol. XLVII.

“Carta Régia concedendo amplíssima jurisdição ao Governador do Rio de Janeiro para os descobrimentos de minas de ouro e prata em Paranaguá, Itabayana e Serra de Sabarabuçú, de 14 de janeiro de 1693", p.34-35.

“Aviso sujeitando São Paulo ao governo do Rio de Janeiro, de 22 de novembro de 1698”, p.36-37.

"Carta de D. João V a Antonio de Albuquerque Coelho de Carvalho sobre a "Guerra dos Emboabas" - de 22 de agosto de 1709”, p.62-65. 
"Carta Régia criando a Capitania de S. Paulo e Minas do Ouro e nomeando governador da mesma a Antonio de Albuquerque Coelho de Carvalho, de 9 de novembro de 1709", p.6568.

"Carta de Antonio de Albuquerque Coelho de Carvalho a D. João V sobre o governo de São Paulo e Minas do Ouro, de 3 de abril de 1710", p.68-70.

"Carta de Antonio de Albuquerque Coelho de Carvalho a D. João V, sobre a "Guerra dos Emboabas", de 3 de abril de 1710", p.71-74.

"Carta de Antonio de Albuquerque Coelho de Carvalho a D. João V sobre o requerimento da Câmara de S. Paulo para que fossem restituídas aos paulistas as terras das minas de que haviam sido expulsos pelos Emboabas, de 26 de abril de 1712", p.80-82.

“Alvará de criação do novo governo de S. Paulo, de 2 de dezembro de 1720", p.94-96.

Documentos Interessantes para a História e Costume de São Paulo. Documentos Relativos ao "Bandeirismo" paulista e questões conexas, no período de 1711 a 1720. Peças Históricas existentes no Arquivo Nacional, e copiadas, coordenadas e anotadas, de ordem do Governo do Estado. Publicação Oficial: Arquivo do Estado de São Paulo; São Paulo: Estabelecimento Gráfico Irmãos Ferraz, 1929. Vol. XLIX.

"Ordem dada a Paulo Nunes Félix por Antonio de Albuquerque, concedendo-lhe a jurisdição de repartidor das Minas de Ouro que descobrira no Districto de Ibitipoca, de 2 de março de 1713", p.99-101.

"Carta Régia mandando que o Governador da Capitania do Rio de Janeiro, ouvido Garcia Rodrigues Paes, presta-se informações sobre a proposta de Jeronymo Camello de S. Paio de continuar os descobrimentos de esmeraldas iniciados pelos Azeredos, de 2 de março de 1714", p.141-143.

"Provisão Régia mandando que o Governador da Capitania do Rio de Janeiro informasse a representação das Câmaras de Guaratinguetá, Pindamonhangaba, Paraty e Taubaté sobre o prejuízo que lhes acarreta a proibição das suas entradas para as Minas, de 22 de fevereiro de 1716", p.187-188.

"Provisão Régia ordenando ao Governador da Capitania do Rio de Janeiro que desse parecer sobre a proposta de Agostinho Azevedo Monteiro, relativa ao descobrimento de minas no interior do Brasil, de 3 de abril de 1716", p.193-194-195.

Documentos Interessantes para a História e Costume de São Paulo. Documentos Relativos ao "Bandeirismo" paulista e questões conexas, no período de 1701 a 1705. Peças Históricas existentes no Arquivo Nacional, e copiadas, coordenadas e anotadas, de ordem do Governo do Estado. Publicação Oficial: Arquivo do Estado de São Paulo; São Paulo: Estabelecimento Gráfico Irmãos Ferraz, 1930. Vol. LI. 
"Carta régia a Arthur de Sá e Menezes sobre a perpetuar-se no Rio de Janeiro a Casa da Moeda e sobre o logar da fundição e quintagem do ouro, de 18 de janeiro de 1701”, p.09.

"Carta régia ao governador e capitão-geral do Rio de Janeiro comunicando-lhe a resolução de se lavrarem por conta da coroa as datas reais e encarregando de prover a esse serviço a Manoel Rodrigues de Arzão, de 30 de janeiro de 1701”, p.16-17.

"Carta régia a Arthur de Sá e Menezes comunicando que ficavam proibidas as comunicações entre as Capitanias da Bahia e Pernambuco e as minas de S. Paulo, pelos sertões, de 7 de fevereiro de 1701", p.19-20.

“Carta Régia a Arthur de Sá e Menezes sobre o cunhador da oficina de fundição confirmada na villa de Taubaté, de 15 de fevereiro de 1701”, p.21.

"Carta Régia a Arthur de Sá e Menezes sobre a pessoa que deve ser nomeada escrivão da oficina de Taubaté, de 23 de fevereiro de 1701”, p.22.

"Patente de capitão-mor da capitania de N. S. da Conceição de Itanhaem a Carlos Pedroso da Silveira, dada por Arthur de Sá e Menezes, de 19 de agosto de 1701”, p.33-34-35.

"Alvará de sesmaria a Francisco Félix Correa, dado por Arthur de Sá e Menezes, de 19 de agosto de 1701", p.35-36.

“Alvará de sesmaria a Manoel de Sousa Silva, dado por Arthur de Sá e Menezes, de 21 de agosto de 1701", p.36-37.

"Ordem de Arthur de Sá e Menezes a Estevam Cavalleiro sobre os mercadores e sobre o ouro em pó, de 23 de setembro de 1701”, p.37-40.

“Ordem de Arthur de Sá e Menezes ao provedor da oficina de Taubaté sobre os mercadores, de 25 de setembro de 1701”, p.40-41.

"Carta régia a Arthur de Sá e Menezes extranhando mui severamente e desaprovando o acto deste pelo qual os serviços dos descobridores de ribeiros auríferos teriam prêmios como os prestados em guerra viva, de 19 de novembro de 1701 ”, p.46.

"Carta régia a Arthur de Sá e Menezes ordenando-lhe desse parecer sobre a representação em que a Câmara de S. Paulo se queixava da falta de índios para que se continuassem os descobrimentos das minas dos Cataguases, de 9 de dezembro de 1701", p.51.

"Carta régia ao governador da Capitania do Rio de Janeiro mandando que se conservasse a casa dos quintos de Taubaté, que tornasse para o Rio de Janeiro a casa da Moeda então em Pernambuco e dispondo outras providências sobre a fabricação da moeda, registro do ouro e pagamento dos quintos, de 31 de janeiro de 1702", p.66.

"Carta régia a Arthur de Sá e Menezes sobre o engenho de cunho destinado a oficina de Taubaté, de 6 de fevereiro de 1702", p.66-67. 
"Carta régia a Arthur de Sá e Menezes sobre o escrivão da oficina de Taubaté, de 6 de fevereiro de 1702", p.67-68.

"Carta de D. Alvaro da Silveira de Albuquerque ao rei sobre exigências anti-regimentais feitas pelos paulistas para manifestarem ribeiros de ouro que haviam descoberto, de 15 de setembro de 1702", p.136.

"Carta de D. Alvaro da Silveira de Albuquerque aos oficiais da Câmara de Taubaté sobre a ida do cunho e do cunhador para a casa de quintos daquela vila, de 20 de setembro de $1702 "$, p.141.

"Carta de D. Alvaro da Silveira e Albuquerque a Miguel Telles da Costa, capitão-mor de Paraty, mandando-lhe por alli arrecadação o cunho, que, por dificuldade de condução, não pode chegar a Taubaté, de 23 de dezembro de 1702", p.146.

"Carta de D. Alvaro da Silveira de Albuquerque ao rei sobre a Casa da Moeda e o ouro nella entrado, de 2 de agosto de 1703", p.196-197.

"Alvará de sesmaria a Serafim Correia, dado por D. Alvaro da Silveira de Albuquerque, de 15 de setembro de 1703", p.206-207.

"Carta de D. Alvaro da Silveira de Albuquerque a Carlos Pedroso da Silveira, provedor da casa de quintos da villa de Taubaté, comunicando-lhe a resolução régia de Sá haver oficinas em Santos e Paraty ordenando-lhe se removesse, com todos os seus oficiais para a ultima das citadas localidades, de 26 de junho de 1704", p.249.

"Carta de D. Alvaro da Silveira de Albuquerque aos oficiais da Câmara de Paraty sobre a casa de quintos que se ia estabelecer naquela villa e sobre providencias relativas aos descaminhos do ouro, de 31 de agosto de 1704", p.256-257.

"Carta de D. Alvaro da Silveira de Albuquerque a Eugênio Preto Matos, provedor dos quintos em Guaratinguetá, comunicando-lhe a resolução régia sobre a extinção da oficina daquela vila e ordenando-lhe que entregasse todos os materiais do mesmo estabelecimento a Carlos Pedroso da Silveira, de 31 de agosto de 1704”, p.257-258.

"Carta de D. Alvaro da Silveira de Albuquerque a Carlos Pedroso da Silveira, provedor dos quintos da villa de Paraty, ordenando-lhe se apressasse em fazer a instalação do dito estabelecimento, de 2 de dezembro de 1704", p.266-267.

"Carta de D. Alvaro da Silveira de Albuquerque a Carlos Pedroso da Silveira, provedor da casa de quintos de Paraty, sobre a instalação da referida oficina e medidas relativas ao descaminho do ouro, de 3 de fevereiro de 1705", p.269-272.

"Provisão de Procurador da Coroa e Fazenda Real da Capitania de N. S. da Conceição de Itanhaém a Carlos Pedroso da Silveira, dada por D. Fernando Martins Mascarenhas de Lencastro, de 5 de setembro de 1705”, p.307-308. 
"Patente de Capitão-mor da Capitania de N. S. da Conceição de Itanhaém a Carlos Pedroso da Silveira, dada por D. Fernando Martins Mascarenhas de Lancastro, de 5 de outubro de 1705", p.310-311.

\section{Documentos Históricos. Vol. IV. 1928}

"Ordem que levou o Capitão João de Castro Fragoso, e Manuel da Silva Pacheco que vão ao descobrimento das minas", p.204-05-06

\section{Documentos Históricos. Vol. VI. 1928}

"Carta que se escreveu ao Capitão Fernão Dias Paes morador na Villa de São Paulo" 20.10.1671, p.201-202-203-204.

"Carta que se escreveu a Fernão Dias Paes sobre o descobrimento da prata e pedraria" 9.07.1673, p.259-260-261.

\section{Documentos Históricos. Vol. VIII. 1929}

"Carta que se escreveu ao Cabo dos Paulistas que andam no Sertão do Rio São Francisco" 07.03.1674, p.385-386.

\section{Documentos Históricos. Vol. X. 1929}

"Carta que se escreveu ao Capitão-mor da Capitania de São Vicente Agostinho de Figueiredo." - 18.03.1675, p.446- 453.

“Carta que se escreveu ao Padre Frei João de Granica sobre as minas." - 18.03.1675, p.45354-55-56.

\section{Revista do Instituto Histórico, Geográfico de São Paulo, Volume XVIII, 1913. São Paulo: Typographia do Diário Oficial, 1914.}

"Carta Régia encarregando a Agostinho Barbalho Bezerra do descobrimento e administração das minas de Paranaguá - de 21 de maio de 1664.” p.276

"Carta Régia mandando dar toda a ajuda e favor a Garcia Rodrigues Paes, como capitãomor da entrada, descobrimento e administração das minas de esmeraldas - de 23 de dezembro de 1683.” p.277.

"Carta Régia mandando remeter ao governador de Angola até 60 casacas estofadas de algodão, iguais ás usadas pelos sertanejos de São Paulo - de 4 de fevereiro de 1684.” p.278.

"Carta Régia mandando dar índios para a diligência das minas de prata e ferro de Sorocaba, realizada por Luis Lopes de Carvalho e Fr. Pedro de Souza - de 8 de fevereiro de 1687." p.279-280. 
"Carta Régia dando poder ao governador do Rio de Janeiro para conceder honras e mercês aos moradores de São Paulo e mais capitanias que se empregassem no descobrimento de ouro e prata - de 13 de janeiro de 1690.” p.284

"Carta Régia dando poder ao governador do Rio de Janeiro para conceder honras e mercês aos moradores de S. Paulo e mais capitanias que se empregassem no descobrimento de minas de ouro e prata - de 16 de janeiro de 1693." p.293-294.

"Alvará Régio em forma de lei providenciando sobre os descaminhos dos quintos do ouro das minas do sul - de 10 de dezembro de 1695." p.303-304.

"Carta Régia ordenando a Arthur de Sá e Menezes que, quando fosse a averiguação das minas de S. Paulo, examinasse também as de Taubaté, de que dera conta Sebastião de Castro Caldas - de 2 de setembro de 1697.” p.309.

"Aviso pelo qual Arthur de Sá e Menezes manda dar auxilio ao Capitão Diogo de Almeida e Lara para o descobrimento de Minas de Prata na Repartição do Sul por Amaro (Fernandes?) - de $1^{\circ}$. de outubro de 1697.” p.310-311.

"Provisão de guarda-mor das Minas dos Cataguases, dada por Artur de Sá e Menezes a Garcia Rodrigues Velho, e, na ausência deste, a Antonio da Rocha Pimental, e na de ambos, a Diogo Gonçalves Moreira - de 13 de janeiro de 1698”. p.324-325.

"Carta de Arthur de Sá e Menezes ao Rei sobre as minas de Taubaté ou dos Cataguazes e sobre o mau procedimento do guarda-mor José de Camargo Pimental - de 29 de abril de 1698." p.331-332.

"Carta de Arthur de Sá e Menezes ao Rei dando-lhe conta dos descaminhos dos quintos do ouro nas minas de S. Paulo, assi como das providencias que ali tomou, vedando as quitas e cuidando de punir a Fr. Roberto e Domingos Dias Torres, fabricantes de cunhos falsos - de 22 de maio de 1698." p.337-338.

"Carta de Arthur de Sá e Menezes ao Rei sobre o empenho que, apesar da falta de mineiro, revelam os paulistas no descobrimento de minas, e sobre a expedição de Gaspar de Godoy Collaço á Vaccaria - de 26 de maio de 1698." p.341-342.

"Carta de Arthur de Sá e Menezes ao Rei perguntando quaes as mercês que podiam ser concedidas aos descobridores de minas de cobre, estanho, salitre e calaim - de 28 de maio de 1698." p.348.

"Carta de Arthur de Sá e Menezes ao Rei dando-lhe conta dos paulistas capazes de empregar-se no real serviço e enviando-lhe uma lista daqueles a quem o soberano davia escrever - de 30 de maio de 1698." p.351-352. 
"Patente, dada por Arthur de Sá e Menezes, a Manuel de Borba Gato, de "Tenente general na jornada do descobrimento da prata de Sabarabussu" - de 15 de outubro de 1698." p.356357.

"Carta Régia sobre os paulistas prontos para o real serviço - de 20 de outubro de 1698." p.358.

"Carta Régia sobre a averiguação das minas que Sebastião de Castro e Caldas tinha descoberto no sitio de Taubaté - de 21 de outubro de 1698.” p.359.

"Carta Régia declarando quaes as recompensas honoríficas que o Governador podia prometer aos paulistas descobridores de minas de cobre, salitre, estanho ou outro qualquer metal de utilidade - de 26 de novembro de 1698." p.364.

"Patente de capitão da Capitania de N. S. da Conceição de Itanhaem, dada a Carlos Pedroso da Silveira por Artur de Sá e Menezes - de 23 de maio de 1699.” p.373-374.

"Carta Régia concedendo licença a Carlos Pedroso da Silveira, provedor dos quintos reais da vila de Taubaté, não havendo inconveniencia, para ir ao reino, afim de lá assistir a requerimentos seus - de 8 de novembro de 1699." p.394.

"Provisão e alvará de Arthur de Sá e Menezes, concedendo a José Moreira de Castilho, Ignácio Moreira e Gaspar Martins uma sesmaria de terras no sertão do rio Verde, a começar do ribeirão do Ponta do Pinheiro para as Minas - de 20 de setembro de 1700.” p.426-427.

"Carta Régia mandando informar o pedido dos oficiais da camara da vila de S. Paulo para que as terras das minas dos Cataguases só fossem dadas de sesmaria aos paulistas, por serem estes os seus conquistadores e descobridores - de 10 de novembro de 1700." p.431432 .

\section{Revista do Instituto Histórico, Geográfico de São Paulo, Volume XLVI, 1951. São Paulo: Typographia do Diário Oficial, 1951.}

"Lembrança dos oficiais mineiros, fundidores, ferreiros e serralheiros que levaram aos governadores abaixo nomeados para as conquistas deste Reino, e dos ordenados que levaram desde o ano de 1584 até o de 1604.” p.245-246-247.

"Carta de Dom Rodrigo Castel Branco da conta do que tem obra na averiguação das minas e de como intenta fazer jornada a Serra de Sabarabuçu - Paranaguá em 14 de fevereiro de 1680." p.250-251.

"Da conta do procedimento de alguns descobrimentos das minas e da prisão de um." p.260261.

Revista do Instituto Histórico, Geográfico de São Paulo, Volume LI, 1953. São Paulo: Typographia do Diário Oficial, 1953. 
"O Marques das minas sobre a última resolução de S.Magestade posta na Consulta a 18 de maio de 1644.” p.302-303 - mercês a serem concedidas a Salvador de Sá.

"Com uma carta original de Salvador Correa de Sá Capitão-mor e Governador do Rio de Janeiro acerca dos particulares das minas de São Paulo.” p.303-308.

Revista do Instituto Histórico, Geográfico de São Paulo, Volume LVII, 1959. São Paulo: Typographia do Diário Oficial, 1959.

"Um documento referente a uma solicitação de Carlos Pedroso da Silveira." - 02.01.1700, p.629-630.

Revista do Instituto Histórico, Geográfico Brasileiro, Tomo LXXI, 1909. Rio de Janeiro: Typographia Universal de Laemmert.

"Descrição Geographica, topographica, historica e politica da Capitania das Minas Geraes seu descobrimento, estado civil, politico e das rendas reaes.” Autor Anônimo - p.117-197.

Revista do Instituto Histórico, Geográfico Brasileiro, Tomo XLVII, 1884. Rio de Janeiro: Typographia Universal de Laemmert.

"Condições ajustadas com o governador dos Paulistas Domingos Jorge Velho em 14 de agosto de 1693 para conquistar e destruir os negros de Palmares". - 03.03.1687. p.19-2021-22-23 e 24.

\section{REFERÊNCIAS BIBLIOGRÁFICAS}

\section{Obras de Referência}

BARATA, Carlos Eduardo de Almeida; BUENO, Antonio Henrique da Cunha. Dicionário das Famílias Brasileiras. Vol. I e II. Originis-X, Sociedade de Pesquisa, 1999.

FRANCO, Francisco de Assis Carvalho. Dicionário de Bandeirantes e Sertanistas do Brasil. São Paulo: Comissão do V Centenário da Cidade de São Paulo, 1954.

SILVA, Antonio de Morais. Dicionário da Língua Portuguesa. Tomo I e II, Tipografia Lacérdina: Lisboa, 1813.

\section{Livros e Artigos}

ABREU, Capistrano de. Capítulos da História Colonial (1500-1800). 6. ed. Rio de Janeiro: Civilização Brasileira; Brasília: INL.

ABREU, Maria Morgado. Taubaté, de núcleo irradiador de bandeirismo a centro industrial e universitário do vale do Paraíba. Aparecida do Norte: Editora Santuário, 1985. 
ABREU, Waldomiro Benedito de. Pindamonhangaba: tempo e face. Aparecida: Editora Santuário, 1977.

AB'SABER, Aziz Nacib; BERNARDES, Nilo. Vale do Paraíba, Serra da Mantiqueira e Arredores de São Paulo. Conselho Nacional de Geografia: Rio de Janeiro, 1958.

ALVES, Maurício Martins. Caminhos da Pobreza: a manutenção da diferença em Taubaté (1680-1729). Taubaté: Prefeitura Municipal, 1998.

. Formas de Viver: formação de laços parentais entre cativos em Taubaté, 1680-1848. Tese de Doutorado, UFRJ, 2001.

ANDRADE, Antônio Carlos de Argôllo; ABREU, Maria Morgado de. História de Taubaté através de Textos. $2^{\mathrm{a}}$. ed. Taubaté: Prefeitura Municipal, 2004.

ANTONIL, André João. Cultura e Opulência do Brasil. $3^{\text {a }}$. Ed. São Paulo: Editora da Universidade de São Paulo, 1982.

ARAÚJO, Emmanuel. O Teatro dos Vícios: transgressão e transigência na sociedade urbana colonial. Rio de Janeiro: J. Olympio Editora, 1993.

BANDECCHI, Brasil. "O município no Brasil e sua formação política (I)”. In: Revista de História. Abril - Junho, vol. XLIV, nº 90, ano XXIII, São Paulo, 1972.

BELMONTE. No Tempo dos Bandeirantes. São Paulo: Governo do Estado, 1980.

BICALHO, Maria Fernanda Baptista; FERLINI, Vera Lúcia Amaral (org). Modos de Governar: idéias e práticas políticas no Império português (séculos XVI a XIX). São Paulo: Alameda, 2005.

BICALHO, Maria Fernanda Baptista. "As Câmaras Municipais no Império Português: O Exemplo do Rio de Janeiro". IN: Revista Brasileira de História. São Paulo, ANPUH/Humanitas Publicações. Vol. 18, nº 36, 1998. p.251-280.

" "As Câmaras ultramarinas e o governo do império."

In: FRAGOSO, João, BICALHO, Maria Fernanda, GOUVÊA, Maria de Fátima (Orgs.). $O$ Antigo Regime nos Trópicos: a dinâmica imperial portuguesa. Rio de Janeiro: Civilização Brasileira, 2001.

BLAJ, Ilana. A Trama das Tensões: o processo de mercantilização de São Paulo colonial (1681-1721). São Paulo: Humanitas; Fapesp, 2002.

- "Agricultores e comerciantes em São Paulo nos inícios do século XVIII: o processo de sedimentação da elite paulistana". IN: Revista Brasileira de História. São Paulo, ANPUH/Humanitas Publicações, Vol. 18, no 36, 1998. p.281-296. 
- "Mentalidade e Sociedade: revisitando a historiografia sobre São Paulo colonial". Revista História. São Paulo. n ${ }^{0}$ 142-143, 2000. p. 239-259.

BORREGO, Maria Aparecida de Menezes. A Teia Mercantil; negócios e poderes em São Paulo colonial (1711-1765). São Paulo: Alameda, 2010.

BOSI, Alfredo. Dialética da Colonização. São Paulo: Companhia das Letras, 1992.

BOXER, Charles R. Salvador de Sá e a Luta pelo Brasil e Angola (1602-1686). São Paulo: Editora Nacional; Editora da USP, 1973.

. A Idade de Ouro do Brasil: dores de crescimento de uma sociedade colonial. $3^{\mathrm{a}}$ ed.Rio de Janeiro: Nova Fronteira, 2000.

. O império colonial português (1415-1825). Lisboa: Edições 70, 1981.

BRUNO, Ernani Silva. História e Tradições da Cidade de São Paulo: arraial de sertanistas (1554-1828). Vol.1. 3ª. ed. São Paulo: Editora Hucitec, 1984.

CALIXTO, Benedito. “Capitanias Paulistas”. In: R.I.H.G.S.P. Vol. 21, 1924.

CALMON, Pedro. História do Brasil. Vol.II. 2ª Ed. Rio de Janeiro: José Olympio, 1963.

CALÓGERAS, João Pandiá. As Minas do Brasil e sua Legislação. Rio de Janeiro: Imprensa Nacional, 1904.

CÂMARA, Leandro Calbente. Administração colonial e poder: a governança da cidade de São Paulo (1765-1802). Dissertação de Mestrado. FFLCH-USP, 2008.

CANABRAVA, Alice P. "Esboço da história econômica de São Paulo". In: BRUNO, Ernani Silva (Org.). São Paulo: terra e povo. Porto Alegre: Globo, 1967.

CARDOSO, Ciro Flamarion S. "Sobre os modos de produção coloniais da América" e "O modo de produção escravista colonial na América". In: SANTIAGO, Théo A. (Org.). América colonial. Rio de Janeiro: Pallas, 1975.

CARRARA, Ângelo Alves. Minas e Currais: produção rural e mercado interno de Minas Gerais (1674-1807). Juiz de Fora: Ed. UFJF, 2007.

CAVAlCANTE, Paulo. Negócios de Trapaça: caminhos e descaminhos na América Portuguesa (1700-1750). São Paulo: Hucitec: Fapesp, 2006.

CHASSOT, Walkiria Costa Fucilli. "Sérgio Buarque de Holanda e a Historiografia Paulista”. Revista de História. São Paulo. nº. 122, p.47-69, jan/jun. 1990.

CORTESÃO, Jaime. Raposo Tavares e a Formação Territorial do Brasil. Rio de Janeiro: Imprensa Nacional, 1958. 
CROSSMAN, R. H. S. Biografia do Estado Moderno. São Paulo: Editora Ciências Humanas, 1980.

CUNHA, Pedro Octávio Carneiro da. "Política e administração de 1640-1763". In: História Geral da Civilização Brasileira: a época colonial. Rio de Janeiro: Bertrand, Tomo I, Volume II, 1989.

DANTAS, Luiz. "O Segredo dos Pinheiros". In: Revista do Instituto de Estudos Brasileiros. $\mathrm{n}^{\circ}$. 23, São Paulo: IEB/USP, 1981.

DAVIDOFF, Carlos. Bandeirantismo: verso e reverso. São Paulo: Brasiliense, 1982. (Col. Tudo é História).

DEUS, Gaspar da Madre de (frei). Memórias para a história da Capitania de São Vicente hoje chamada de São Paulo e notícias dos anos em que se descobriu o Brasil. São Paulo: Martins Editora, 1953.

ELLIS JÚNIOR, Alfredo. Raça de Gigantes: a civilização no planalto paulista. São Paulo: Editora Helios Limitada, 1926.

. O Bandeirismo Paulista e o Recuo do Meridiano. São Paulo: Companhia Editora Nacional, 2ª Edição, 1934.

. "A economia paulista no século XVIII. O ciclo do muar; o ciclo do açúcar.”, In: ELLIS Jr., Alfredo; ELLIS, Myriam. A economia paulista no século XVIII. São Paulo: Boletim da Civilização Brasileira, nº 11, 1950. p. 5-145.

ELLIS, Myriam. "As Bandeiras na expansão geográfica do Brasil". In: HOLANDA, Sérgio Buarque de. História Geral da Civilização Brasileira, Tomo I, Volume I, Rio de Janeiro: Bertrand, 1989. p. 273-296.

- "São Paulo, de Capitania a Província. Pontos de Partida para uma História Político-administrativa da Capitania de São Paulo". In: Revista de História. Julho - Setembro, Vol. LII, no 103, Ano XXVI, São Paulo, 1975.

FAORO, Raymundo. Os Donos do Poder. Volume I. Porto Alegre: Globo, 1984.

FARIA, Sheila de Castro. A Colônia em Movimento: fortuna e família no cotidiano colonial. Rio de Janeiro: Nova Fronteira, 1998.

FERNANDES, Florestan. "A Sociedade Escravista no Brasil”. In: Circuito Fechado. São Paulo: Hucitec, $2^{\mathrm{a}}$ Edição, 1977.

FERREIRA, Tito Lívio; FERREIRA, Manoel Rodrigues. História da Civilização Brasileira. São Paulo: Ed. Gráfica Biblos, 1959. 
FLORENÇANO, Paulo Camilher. O Brasão e a Bandeira de Taubaté. 2a . ed. Taubaté: Resolução Gráfica.

FLORENTINO, Manolo; FRAGOSO, João. O Arcaísmo como Projeto: mercado atlântico, sociedade agrária e elite mercantil em uma economia colonial tardia: Rio de Janeiro, c.1790 - c.1840. Rio de Janeiro: Civilização Brasileira, 2001.

FOUCAULT, Michel. Segurança, Território e População: curso dado no Collège de France (1977-1978). São Paulo: Martins Fontes, 2008.

FRAGOSO, João; BICALHO, Maria Fernanda Baptista; GOUVÊA, Maria de Fátima Silva (org.). O Antigo Regime nos Trópicos: a dinâmica imperial portuguesa (séculos XVIXVIII). Rio de Janeiro: Civilização Brasileira, 2001.

FURTADO, Celso. Formação Econômica do Brasil. 15a . ed. São Paulo, Editora Nacional, 1977.

FURTADO, Júnia Ferreira. Homens de Negócio: a interiorização da metrópole e o comércio das minas setecentistas. 2ª . ed. São Paulo: Hucitec, 2006.

GLEZER, Raquel. Chão de Terra e outros Ensaios sobre São Paulo. São Paulo: Alameda, 2007.

GORENDER, Jacob. O escravismo colonial. São Paulo: Ática, 1978.

GUISARD FILHO, Félix. Jacques Félix. Achegas à história de Taubaté. São Paulo: Athena Editora, 1938.

Paulo: Athena Editora, 1938.

Convento de Santa Clara. Achegas à história de Taubaté. São .Nomes, Limites e Brasões. Itacurussá.Achegas à história de

Taubaté. São Paulo: Athena Editora, 1939.

HERRMANN, Lucila. Evolução da Estrutura Social de Guaratinguetá num Período de Trezentos Anos. São Paulo: Instituto de Pesquisas Econômicas - USP,1986.

HOLANDA, Sérgio Buarque de. Caminhos e Fronteiras. São Paulo: Companhia das Letras, $3^{\text {a }}$ Edição, 1994.

- "Movimentos da população de São Paulo no século XVIII”. Revista do Instituto de Estudos Brasileiros. São Paulo, v.1, 1966.

Editora, $7^{\text {a }}$ Edição, 1973. Raízes do Brasil. Rio de Janeiro: Livraria José Olympio descobrimento e colonização do Brasil. São Paulo: Brasiliense, 6ª Edição, 1994. 
. (dir.). História Geral da Civilização Brasileira: a época colonial. Rio de Janeiro: Bertrand, Tomo I, Volume I e II, 1989.

. "Caminhos do Sertão". In: Revista de História. Janeiro Março. Vol. XXVIII, nº 57, ano XV, São Paulo, 1964.

IGLÉSIAS, Francisco. Os Historiadores do Brasil: capítulos de historiografia brasileira. Rio de Janeiro: Nova Fronteira; Belo Horizonte: UFMG, IPEA, 2000.

KNIVET, Anthony. As Incríveis Aventuras e Estranhos Infortúnios de Anthony Knivet. São Paulo: Companhia das Letras, 2007.

KOK, Glória Porto. O Sertão Itinerante: expedições da capitania de São Paulo no século XVIII. São Paulo: Hucitec: Fapesp, 2004.

LARA, Silvia Hunold; MENDONÇA, Joseli Maria Nunes. (orgs). Direitos e Justiças no Brasil: ensaios de história social. Campinas: Editora da Unicamp, 2006.

LEME, Pedro Taques de Almeida Paes. Nobiliarquia paulistana histórica e genealógica (1767-1772). 5. ed. Belo Horizonte: Itatiaia, São Paulo: Edusp, 1980. 3 v.

.Informação sobre as minas de S. Paulo. A expulsão dos jesuítas do collegio de S. Paulo, (1772). São Paulo: Melhoramentos, s. d;

Paulo: Melhoramentos, s. d.

.História da capitania de São Vicente (1772). São

LIMA, J. A. Cunha. "As Descobertas do Ouro e o Regime Jurídico e Administrativo das Minas". In: Revista do Arquivo Municipal. Vol.CLXXI - Ano XXIX.

LUIS, Washington. Na capitania de São Vicente. Belo Horizonte: Itatiaia; São Paulo: Edusp, 1980.

MACEDO, José Felício Buarque de. "Ação das Bandeiras." In: R.I.H.G.S.P. Volume XIV. São Paulo: Typographia do Diário Oficial, 1912.

MACHADO, Alcântara. Vida e Morte do Bandeirante. Coleção Paulística. Vol. XIII. São Paulo: Imprensa Oficial, 2006.

MAGALHÃES, Basílio de. Expansão Geográfica do Brasil Colonial. Rio de Janeiro: Epasa, 2a Edição, 1944.

MAGALHÃES, Basílio de. "O Bandeirismo no Brasil: subsídios para o estudo deste importante fenômeno da nossa evolução." In: R.I.H.G.B. Tomo LXXVII. Rio de Janeiro: Typographia Universal de Laemmert, 1915. 
MARANHO, Milena Fernandes. A Opulência Relativizada: significados econômicos e sociais dos níveis de vida dos habitantes da região do Planalto de Piratininga (16481682). Dissertação de Mestrado: Unicamp, 2000.

MARCÍLIO, Maria Luiza. Crescimento demográfico e evolução agrária paulista: 17001836. Tese (Livre-Docência) - Faculdade de Filosofia, Letras e Ciências Humanas, Universidade de São Paulo, São Paulo, 1974.

MARTINS, Gilberto. Taubaté nos Seus Primeiros Tempos. Taubaté: Empresa Gráfica Editora Taubaté, 1973.

MELlO, Christiane F. Pagano de. Forças Militares no Brasil Colonial: Corpos de Auxiliares e de Ordenanças na segunda metade do Século XVIII. Rio de Janeiro: E-Papers, 2009.

MELLO, Evaldo Cabral de. Rubro Veio: o imaginário da Restauração Pernanbucana. Rio de Janeiro: Nova Fronteira,1986.

MONTEIRO, John Manuel. Negros da Terra.Índios e bandeirantes nas origens de São Paulo. São Paulo: Companhia das Letras, 1995.

Tupis, Tapuias e Historiadores: estudos de História Indígena e do Indigenismo. Livre Docência: Unicamp, 2001.

MONTEIRO, Rodrigo Bentes. O Rei no Espelho: a monarquia portuguesa e a colonização da América (1640-1720). São Paulo: Hucitec; Fapesp, 2002.

MOOG, Clodomir Vianna. Bandeirantes e Pioneiros: paralelo entre duas culturas. $10^{\mathrm{a}}$. ed. Porto Alegre: Editora Globo, 1973.

MORSE, Richard M. Formação histórica de São Paulo (de comunidade à metrópole).2a . Ed. São Paulo: Difusão Européia do Livro, 1970.

MOURA, Gentil de Assis. "As Bandeiras Paulistas: estabelecimentos das diretrizes gerais a que obedecem e estudo das zonas que alcançaram.” In: R.I.H.G.S.P. Vol. XIX. São Paulo: Typographia do Diário Oficial, 1915.

MÜLlER, Daniel Pedro. Ensaio d'um Quadro Estatístico da Província de S. Paulo. Reedição. São Paulo: Governo do Estado, 1923.

NEVES, Cylaine Maria das. A Vila de São Paulo de Piratininga: fundação e representação. São Paulo: Annablume; Fapesp, 2007.

NOVAIS, Fernando A. Portugal e Brasil na Crise do Antigo Sistema Colonial (17771808). 6a . Ed. Editora Hucitec: São Paulo, 1995. 
. "Condições da Privacidade na Colônia." In: SOUZA, Laura de Mello e (org.). História da Vida Privada no Brasil: cotidiano e vida privada na América portuguesa. Vol. I. São Paulo: Companhia das Letras, 1997.

OLIVAL, Fernanda. As Ordens Militares e o Estado Moderno: honra, mercê e venalidade em Portugal (1641-1789).Lisboa: Estar, 2001.

"Rigor e Interesses: os estatutos de limpeza de sangue em Portugal." In: Cadernos de Estudos Sefarditas. n. 4, 2004.

ORLANDO, Artur. "Bandeirantes”. In: R.I.H.G.S.P. Volume XIV. São Paulo: Typographia do Diário Oficial, 1912.

ORTIZ, José Bernardo. São Francisco das Chagas de Taubaté. Vol. I e II. Prefeitura de Taubaté, 1996.

PINTO, Virgílio Noya. O Ouro Brasileiro e o Comércio Anglo-Português. São Paulo: Editora Nacional, 1979.

POMBO, Rocha. História do Brasil. 4a . Edição. São Paulo: Companhia Melhoramentos de São Paulo. 1941.

PRADO, Paulo. Paulística. História de São Paulo. São Paulo: Monteiro Lobato, 1925.

PRADO JÚNIOR, Caio. Formação do Brasil Contemporâneo: colônia. São Paulo: Livraria Martins, 1942.

Brasiliense, 1953.

Evolução Política do Brasil e outros estudos. $3^{\mathrm{a}}$. ed. São Paulo:

Brasiliense, 1998. . História Econômica do Brasil. 45a . Reimpressão. São Paulo:

QUEIRÓS, Suely Robles Reis de. Escravidão Negra em São Paulo: um estudo das tensões provocadas pelo escravismo no século XIX. Rio de Janeiro: José Olympio, 1977.

RANGEL, Armênio de Souza. Escravismo e Riqueza: formação da economia cafeeira no município de Taubaté (1765-1835). São Paulo: Tese de Doutorado: Faculdade de Economia - Universidade de São Paulo, 1990.

REIS, Paulo Pereira dos. O caminho Novo da Piedade no Nordeste da Capitania de S. Paulo. São Paulo: Conselho Estadual de Cultura, 1971.

de São Paulo, 1979.

. O Indígena do Vale do Paraíba. São Paulo: Governo do Estado

RICARDO, Cassiano. Marcha para o Oeste. Rio de Janeiro: Livraria José Olympio Editora, 1959. 
RICUPERO, Rodrigo. A Formação da Elite Colonial: Brasil, c.1530 - c.1630. São Paulo: Alameda, 2009.

ROMEIRO, Adriana. Paulistas e Emboabas no Coração das Minas: idéias, práticas e imaginário político no século XVIII. Belo Horizonte: Editora UFMG, 2008.

RUIZ, Rafael. São Paulo na Monarquia Hispânica. São Paulo: Instituto Brasileiro de Filosofia e Ciência "Raimundo Lúlio" (Ramon Llull), 2004.

RUSSEL-WOOD, A. J. R. "Centros e Periferias no Mundo Luso-Brasileiro, 1500-1808”. IN: Revista Brasileira de História. São Paulo, ANPUH/Humanitas Publicações, Vol. 18, ${ }^{\circ}$ 36, 1998.

SAINT-HILAIRE, Augustin. Viagem a Província de São Paulo. São Paulo: Itatiaia, 1976.

SALDANHA, António Vasconcelos de. As Capitanias do Brasil: antecedentes, desenvolvimento e extinção de um fenómeno atlântico. Lisboa: Comissão Nacional para as Comemorações dos Descobrimentos Portugueses, 2001.

SALGADO, Graça (Coord.). Fiscais e Meirinhos. A administração no Brasil colonial. Rio de Janeiro: Nova Fronteira; Brasília: INL, 1985.

SALVADOR, José Gonçalves. "Os transportes em São Paulo no período colonial (Subsídios para a História de São Paulo)”. In: Revista de História, Julho - Setembro, n 39, ano X, São Paulo, 1959.

SANTOS, Márcio. Bandeirantes Paulistas no Sertão do São Francisco: povoamento e expansão pecuária de 1688 a 1734. São Paulo: Editora da Universidade de São Paulo, 2009.

SCANTIMBURGO, João de. Os Paulistas. São Paulo: Imprensa Oficial do Estado de São Paulo, 2006. (Coleção Paulística, v. XXI)

SCHWARTZ, Stuart B. Burocracia e Sociedade no Brasil Colonial: a suprema corte da Bahia e seus juízes: 1609-1751. São Paulo: Editora Perspectiva, 1979.

. "Prata, açúcar e escravos: de como o império restaurou Portugal".

In: Revista Tempo, vol. 12, n. 24, 2008.

Bauru, SP: Edusc, 2009.

; MYRUP, Erik (org.). O Brasil no Império Marítimo Português.

SILVA, Flávio Marcus da. Subsistência e Poder; a política do abastecimento alimentar nas Minas setecentistas. Tese de Doutorado, Belo Horizonte: UFMG, 2002.

SILVA, Raul de Andrade e. "São Paulo nos tempos coloniais". In: AZEVEDO, Aroldo (Org.) A Cidade de São Paulo. Estudos de geografia urbana. v.II. 
SILVA, Maria Beatriz Nizza da (org.). História de São Paulo Colonial. São Paulo: Editora UNESP, 2009.

SILVEIRA, Carlos da. "Cristovam Diniz de Anhaya, um paulista andejo." In: Revista do Arquivo Municipal de São Paulo. Ano I, abril de 1935. São Paulo, vol. XI.

. "Carlos Pedroso da Silveira". R.I.H.G.S.P. Vol. XXX. São Paulo:

Typographia do Diário Oficial, 1935.

SOUZA, George Félix Cabral de. Os Homens e os Modos da Governança: a Câmara Municipal do Recife do século XVIII num fragmento da história das instituições municipais do Império Colonial Português. Dissertação de Mestrado em História: Universidade Federal de Pernambuco, 2002.

SOUZA, Laura de Mello e. Desclassificados do Ouro: a pobreza mineira no século XVIII. São Paulo: Graal, 1986.

caminhos, nas fronteiras e nas fortificações." In: SOUZA, Laura de Mello e (org.). História da Vida Privada no Brasil: cotidiano e vida privada na América portuguesa. Vol. I. São Paulo: Companhia das Letras, 1997.

- O Sol e a Sombra: política e administração na América Portuguesa do século XVIII. São Paulo: Companhia das Letras, 2006.

; BICALHO, Maria Fernanda Baptista. 1680-1720: o império deste mundo. São Paulo: Companhia das Letras, 2000.

TAUNAY, Affonso de E. História das Bandeiras Paulistas. São Paulo: Edições Melhoramentos, Tomo I, 2a Edição, 1961.

História Geral das Bandeiras Paulistas. São Paulo: Typografia Ideal, vols. 1-7 (1924-1936). São Paulo: Museu Paulista - Imprensa Oficial do Estado, vols. 8-11 (1946-1950).

s.d.

. História da Cidade de São Paulo. São Paulo: Melhoramentos, 1981. . Relatos Sertanistas. Belo Horizonte-São Paulo: Itatiaia-Edusp,

(1554-1601). São Paulo: Paz e Terra, 2003.

TOLEDO, Francisco de Paula. História do Município de Taubaté. 2ª . Ed. Prefeitura Municipal de Taubaté, 1976. 
WEBER, Max. Economia e Sociedade: fundamentos da sociologia compreensiva. $4^{\mathrm{a}}$. ed. Vol. 1. Brasília: Editora Universidade de Brasília, 2009.

VASCONCELOS, Diogo de. História Antiga das Minas Gerais. 3ª . ed. Belo Horizonte: Itatiaia, Vol. I, 1974.

VIANNA, Oliveira. Populações Meridionaes do Brasil. 4. ed. São Paulo: Ed. Nacional, 1938.

Instituições Políticas Brasileiras. Vol.I Fundamentos Sociais do Estado (Direito Público e Cultura). 2a . Edição. São Paulo: José Olympio, 1955.

VOLPATO, Luiza, Rios Ricci. Entradas e Bandeiras. São Paulo: Global, 1985.

ZENHA, Edmundo. Mamelucos. São Paulo: Empresa Gráfica da Revista dos Tribunais, 1970.

ZEMELLA, Mafalda P. O Abastecimento da Capitania das Minas Gerais no século XVIII. São Paulo: Hucitec: Editora da USP, 2a Edição, 1990. 